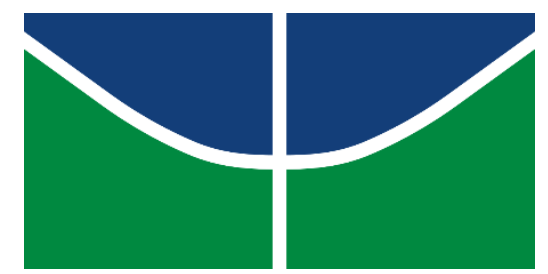

Universidade de Brasília - UnB

Faculdade de Direito

RAPHAEL MARCELINO DE ALMEIDA NUNES

\title{
O MODELO DEMOCRÁTICO DE PROPRIEDADE NO BRASIL
}




\section{O MODELO DEMOCRÁTICO DE PROPRIEDADE NO BRASIL}

Dissertação apresentada como requisito parcial à obtenção do grau de Mestre no Programa de Pós-Graduação da Faculdade de Direito da Universidade de Brasília, linha de pesquisa "Transformações na Ordem Social e Econômica e Regulação".

Orientador: Prof. Dr. Frederico Henrique Viegas de Lima. Brasília

Brasília 


\section{O MODELO DEMOCRÁTICO DE PROPRIEDADE NO BRASIL}

Dissertação apresentada como requisito parcial à obtenção do grau de Mestre no Programa de Pós-Graduação da Faculdade de Direito da Universidade de Brasília, linha de pesquisa "Transformações na Ordem Social e Econômica e Regulação".

Brasília/DF, em de de 2017.

\section{BANCA EXAMINADORA}

Prof. Dr. Frederico Henrique Viegas de Lima

(Orientador - Presidente)

Prof. Dr. Luiz Edson Fachin

(Examinador Externo)

Prof. Dr. Gilmar Ferreira Mendes

(Examinador Interno)

Profa. Dra. Ana Frazão

(Examinadora Interna) 
Aos meus pais, Geraldo e Eny, cuja bela trajetória de vida lega aos filhos a honrosa missão de busca e produção de conhecimento. 
Liberdade (independência do arbítrio coercitivo de um outro), na medida em que pode subsistir com a liberdade de qualquer outro de acordo com uma lei universal, é este direito único, originário, pertencente a cada homem por força de sua humanidade.

(Immanuel Kant $)^{1}$

\footnotetext{
${ }^{1}$ (Kant I. , Princípios Metafísicos da Doutrina do Direito, 2014, pp. 42-43)
} 


\section{RESUMO}

Este trabalho tem por objetivo traçar os parâmetros de um modelo democrático de propriedade no Brasil, sob a perspectiva do Direito Civil-Constitucional, no âmbito do Estado Democrático de Direito, sob a égide da Constituição Federal de 1988. Para alcançar o objetivo pretendido, o estudo explora os avanços e os limites da concepção de direito de propriedade desenvolvida pelos autores civilistas clássicos da doutrina brasileira. Com vistas a superar a concepção clássica, e com o intuito de delinear os parâmetros democráticos que devem nortear a concepção de direito de propriedade, examinam-se os argumentos elaborados pelo liberalismo clássico e seus principais expoentes. Em contraponto, são aventadas as contradições inerentes ao liberalismo clássico, expostas por autores como Comte, Durkheim e Marx. Nesse contexto, apresentase a formulação da concepção da função social da propriedade e os avanços proporcionados na conformação do conteúdo do direito de propriedade. Adicionalmente, são discutidas as possibilidades contributivas advindas com teorias consequencialistas, como utilitarismo e análise econômica do direito. Sob as perspectivas argumentativas apresentadas, é analisado o fenômeno da constitucionalização do Direito Civil, com enfoque na experiência constitucional brasileira, com vistas a examinar os aspectos valorativos consubstanciados no texto constitucional pátrio. Diante do arcabouço teórico fundamental, devidamente contextualizado na experiência constitucional brasileira, é proposta uma teoria de direito a respeito da propriedade, pela perspectiva de Jeremy Waldron, com os avanços desenvolvidos por Joseph William Singer. De tal análise resulta a proposição de um modelo democrático de propriedade, devidamente situado em nosso contexto jurídico-constitucional.

Palavras-chave: Direito Civil Constitucional, Estado Democrático de Direito; Estado Liberal; Estado Social; Utilitarismo; Análise Econômica do Direito; Direito de Propriedade; Função Social da Propriedade; Modelo Democrático de Propriedade 


\begin{abstract}
This research aims at drawing the parameters of a democratic model of property law in Brazil, from the perspective of a Constitutional Civil-Law, within the Democratic State of Right, under the Federal Constitution of 1988. In order to achieve the goals proposed, this study explores the advances and the limits of a property law conception developed by traditional Brazilian civil-law authors. The study examines the arguments developed by the classical liberalism and its main authors, with the purpose of overruling the traditional conception and outlining democratic parameters that must guide the conception of property law. In contrast, the contradictions of classic liberalism, as exposed by authors like Comte, Durkheim and Marx, are also presented. In this context, the paper explores the conception of the social function of private property and its advances toward the development of the content of the right to private property. In addition, it discusses the contributions provided by consequentialists theories, as utilitarism and law and economics. Based on the arguments presented, and in order to examine the values inscribed in the constitutional text, the Brazilian constitutional experience related to the Constitutional-Civil law is analyzed. Then, it is proposed a theory of right regarding the private property, as developed by Jeremy Waldron, associated with Joseph Willian Singer's contributions, within the Brazilian constitutional experience. From this analysis it is outlined the democratic model of property right in Brazilian law context.
\end{abstract}

Key-words: Constitutional Civil-Law, Democratic State of Right; Liberal State; Social State; Utilitarism; Law and Economics; Property Law; Social Function of Private Property; Democratic Model of Property Law 


\section{LISTA DE ABREVIATURAS}

BGB - Bürgerliches Gesetzbuch - Código Civil alemão

BVerfGE - Entscheidungen des Bundesverfassungsgerichts - Decisões do Tribunal Constitucional Federal

$\mathrm{HC}$ - Habeas Corpus

MPDFT - Ministério Público do Distrito Federal e dos Territórios

MS - Mandado de Segurança

RE - Recurso Extraordinário

STF - Supremo Tribunal Federal

STJ - Superior Tribunal de Justiça 


\section{Sumário}

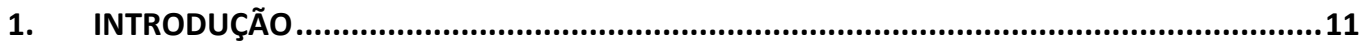

2. A CONCEITUAÇÃO CLÁSSICA DO DIREITO DE PROPRIEDADE NO BRASIL...........................20

3. FUNDAMENTOS LIBERAIS DO DIREITO DE PROPRIEDADE..............................................30

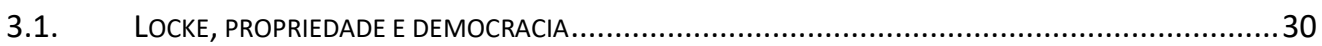

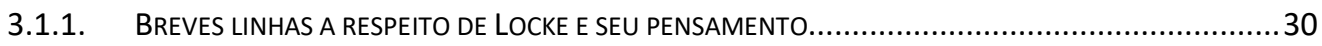

3.1.2. LOCKE E A SUA CONCEPÇÃO DE IGUALDADE (O INTELECTO DEMOCRÁTICO) .................................32

3.1.3. A TEORIA DE DIREITO DE PROPRIEDADE EM LOCKE...................................................... 35

3.2. LIBERDADE COMO FUNDAMENTO DO DIREITO DE PROPRIEDADE: A CONCEPÇÃO DE KANT ..............41

3.2.1. OS FUNDAMENTOS MORAIS DA TEORIA DE KANT A PARTIR DA IDEIA DE LIBERDADE ....................41

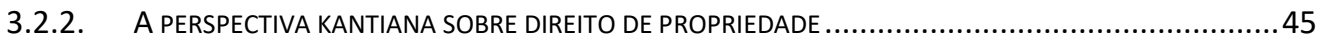

3.2.2.1. A LIBERDADE COMO DIREITO NATURAL E O PRINCÍPIO UNIVERSAL DO DIREITO ......................45

3.2.2.2. DIREITO À PROPRIEDADE PRIVADA E DIREITOS ADQUIRIDOS .......................................... 47

3.2.2.3. DIREITO DE PROPRIEDADE, O PRESSUPOSTO DO ESTADO CIVIL E SUAS CONSEQUÊNCIAS ............50

3.3. A PERSPECTIVA HEGELIANA SOBRE DIREITO DE PROPRIEDADE..............................................57

3.3.1. O LEGADO CRÍTICO DE HEGEL AO LIBERALISMO..........................................................57

3.3.2. A CONCEPÇÃO DE DIREITO DE PROPRIEDADE DE HEGEL ................................................58

4. O PARADIGMA DO ESTADO SOCIAL E DIREITO DE PROPRIEDADE ...............................64

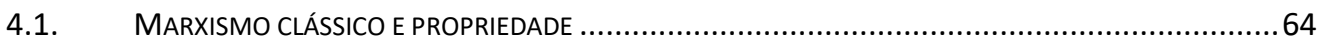

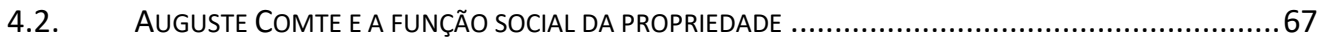

4.3. DURKHEIM, PROPRIEDADE E A IDEIA DE SOLIDARIEDADE SOCIAL ....................................... 70

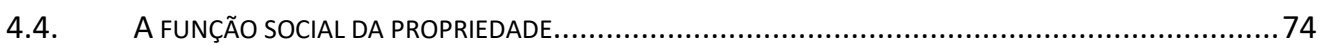

4.4.1. A FUNÇÃO SOCIAL COMO UM SUBPRODUTO DA CRISE DO LIBERALISMO ...................................74

4.4.2. A FUNÇÃO SOCIAL DA PROPRIEDADE E O PAPEL DO ESTADO .............................................76

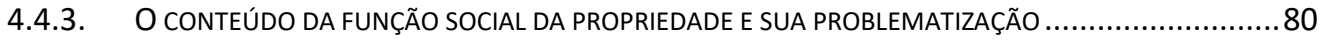

5. UTILITARISMO, ANÁLISE ECONÔMICA DO DIREITO E PROPRIEDADE ............................99

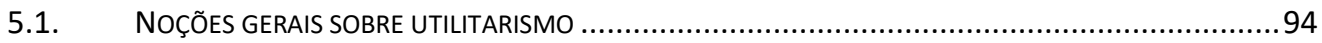

5.2. BREVES LINHAS SOBRE A UTILIDADE E A UTILIDADE AGREGADA .......................................... 95

5.3. UTILITARISMO, ANÁLISE ECONÔMICA DO DIREITO E DIREITO DE PROPRIEDADE .........................97

5.4. O UTILITARISMO E A ANÁLISE ECONÔMICA DO DIREITO ....................................................... 97

5.5. AS DIMENSÕES POSITIVA E NORMATIVA DA ANÁLISE ECONÔMICA DO DIREITO ...........................99 
5.6. CONCEITOS E ASSUNÇÕES RELEVANTES DAS TEORIAS ECONÔMICAS DO DIREITO: UMA ANÁLISE DA

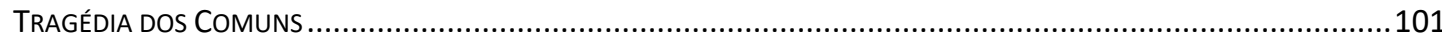

5.7. CRÍTICAS AO UTILITARISMO E ÀS CONCEPÇÕES ECONÔMICAS DO DIREITO.................................107

5.8. BREVES COMENTÁRIOS ACERCA DAS CONTRIBUIÇÕES DAS TEORIAS ECONÔMICAS DO DIREITO .......110

6. A CONSTITUCIONALIZAÇÃO DO DIREITO DE PROPRIEDADE ....................................114

6.1. A CONSTITUCIONALIZAÇÃO DO DiREITO CIVIL.............................................................. 114

6.2. A CONSTITUCIONALIZAÇÃO DO DIREITO DE PROPRIEDADE E A EXPERIÊNCIA BRASILEIRA ................119

6.3. A CONSTITUCIONALIZAÇÃO DO DIREITO DE PROPRIEDADE E A QUESTÃO DA EFICÁCIA DOS DIREITOS FUNDAMENTAIS 138

7. O MODELO DEMOCRÁTICO DE PROPRIEDADE 147

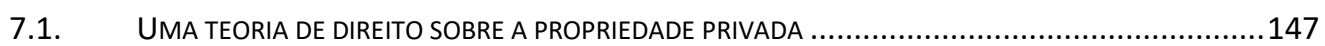

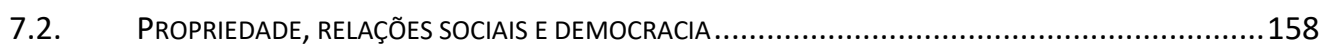

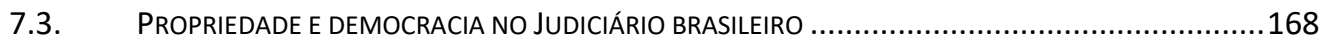

7.3.1. INVASÃO DE PROPRIEDADE, REFORMA AGRÁRIA E O DIREITO DE PROPRIEDADE (“MS 24.764”)...171

7.3.2. A FUNÇÃO SOCIAL DA PROPRIEDADE E O SOLO CRIADO. (“RE 387047”) ................................176

7.3.3. A ORDEM URBANÍSTICA E O PODER NORMATIVO DA MUNICIPALIDADE. (“RE 607940”) ............182

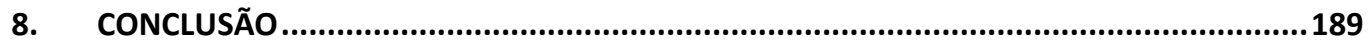

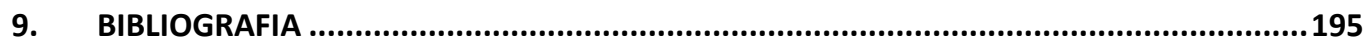




\section{Introdução}

Em sua concepção acerca do direito de propriedade, John Locke desenvolve a ideia de que Deus teria dado a terra a todos os homens para que, com o emprego do trabalho, pudessem legitimamente se apropriar de parcelas daquilo que Ele teria destinado, em comum, aos seres humanos. (Locke, 2011, p. 29)

Tal direito, que é natural e decorrente tão somente da condição humana, prescindiria de qualquer pacto para que pudesse ser exercido e respeitado pelos demais. Ou seja, desde que houvesse o emprego do trabalho, haveria legitimidade na apropriação de qualquer coisa que estivesse em seu estado natural.

A descrição de Locke do estado natural nos remete a uma ideia de abundância de recursos necessários à sobrevivência humana, em nome da qual a livre apropriação, pelo emprego do trabalho, se legitimaria. Nada obstante, parece ser uma preocupação de Locke a crítica decorrente de eventual possibilidade de apropriação em excesso, em detrimento dos demais, por parte de alguém. Nesse contexto, em relação ao problema da finitude dos recursos disponíveis, assim responde Locke:

E tampouco esta apropriação de qualquer parcela de terra pela sua melhoria implicava em prejuízo para outrem, uma vez que ainda havia dela bastante e de boa qualidade à disposição, e mais do que os não-possuidores pudessem usar. (Locke, 2011, p. 32)

Essa ideia do estado natural com abundância de recursos livres à apropriação humana, como, aliás, o próprio Locke reconhece, não prevalece, todavia, em realidades de contextos diversos daquele vivenciado por Adão e Eva (para tanto, ele utiliza o exemplo do contexto urbano de Londres, à época) (Locke, 2011, p. 33).

E essa realidade imaginada por Locke não é viável exatamente em razão do problema da finitude dos recursos disponíveis vis-à-vis os interesses conflitantes que sobre eles recaem.

A propósito desse problema, Garrett Hardin produziu o clássico ensaio intitulado The Tragedy of Commons (Hardin, 1968), por meio do qual retrata explicitamente o problema da limitação dos recursos confrontado com o da decisão acerca do destino de uma propriedade em comum. 
Em seu texto, Hardin traz a imagem de um pasto aberto a todos. Nesse cenário, há a expectativa de que cada um dos pastores tentará manter a maior quantidade de gado possível no pasto comum. Essa lógica poderia funcionar por séculos, haja vista a possibilidade de existência de guerras tribais, caça e doenças, que resultariam em um controle do número de pessoas e de gado compatível com um certo equilíbrio com a capacidade da terra utilizada no pasto.

No entanto, diante de um cenário de estabilidade social, o referido equilíbrio se perderia e a lógica dos comuns resultaria em tragédia.

De fato, racionalmente, o pastor, individualmente, tenderia a buscar a maximização dos seus ganhos. Nesse racional, o pastor chegaria à conclusão de que, adicionando mais uma cabeça de gado no pasto, ele teria um ganho equivalente a +1 , enquanto os demais suportariam uma perda correspondente a uma fração de -1 , como decorrência do excesso de pastagem.

Nessa lógica, segundo Hardin, residiria a inevitável tragédia, pois o pastor estaria sempre racionalmente compelido a aumentar o seu rebanho em um sistema que é limitado. E, nesse contexto, assevera Hardin:

\footnotetext{
Ruin is the destination toward which all men rush, each pursuing his own best interest in a society that believes in the freedom of the commons. Freedom in a commons brings ruin to all. (Hardin, 1968, p. 1244)
}

Hardin transporta a ideia da tragédia dos comuns para vários problemas relacionados à escassez de recursos e a finitude dos bens materiais existentes. Nesse sentido, v.g., a decisão do poluidor em aumentar a degradação de determinado ambiente tendo como contrapartida o incremento de seus resultados poderia seguir a mesma lógica de raciocínio, também resultando em tragédia, caso não se tomem medidas para romper o racional de custo/benefício original.

Sem adentrar nas discussões em relação a controle populacional defendidas por Hardin, o fato é que a tragédia dos comuns nos remete a reflexões importantes em relação ao sistema de decisão sobre a destinação dos recursos.

Seria a garantia e o reforço do direito de propriedade individual a solução para os referidos problemas? 
O direito de propriedade individual, que traz em seu âmbito a atribuição do poder decisório a um determinado indivíduo - assim retirando aquela propriedade do sistema “dos comuns" - faz com que, de certo modo, se evite a tragédia propagada por Hardin.

A propósito do tema, afirma:

With real estate and other material goods, the alternative we have chosen is the institution of private property coupled with legal inheritance. Is this system perfectly just?

We must admit that our legal system of private property plus inheritance is unjust-but we put up with it because we are not convinced, at the moment, that anyone has invented a better system. The alternative of the commons is too horrifying to contemplate. Injustice is preferable to total ruin. (Hardin, 1968, p. 1247)

O temor à tragédia dos comuns seria, de fato, suficiente para justificar um sistema de direito de propriedade fundamentado nas decisões individuais?

O presente trabalho objetiva, inicialmente, portanto, apresentar argumentos que justifiquem a existência de um sistema de direito de propriedade. Ou seja, defende-se a legitimidade de um sistema que se fundamenta em uma instituição social caracterizada pela decisão individual de um determinado sujeito acerca da alocação/disponibilidade de um recurso.

Isso não significa que o conteúdo, as características e os efeitos dessa decisão - e principalmente os argumentos que justificam essa legitimidade - sejam claros, objetivos e unanimemente aceitos. Mais ainda, isso não significa que esse poder de decisão e a sua legitimidade sejam de caráter absoluto.

O conteúdo do direito de propriedade é dinâmico e, de certa forma, ambíguo. Considerando esses aspectos, precisa ser analisado. Deve-se reconhecer, desse modo, que, sobre a instituição do direito de propriedade, recai uma pluralidade de interesses legítimos, que devem ser reconhecidos e contemplados. Ainda assim, no entanto, devese enfatizar que os conflitos e os enfrentamentos que envolvem os referidos interesses devem se dar no âmbito da discussão sobre o direito de propriedade, mediante procedimentos democráticos. 
Em linhas gerais, e sob a perspectiva do sujeito titular desse direito (ou potencialmente titular), podem ser verificados alguns interesses normalmente aventados no âmbito das discussões sobre direito de propriedade. No decorrer do presente trabalho, como acima mencionado, os referidos interesses serão delineados e, ao final, testados e confrontados sob perspectivas pluralistas e democráticas, de modo a se alcançar os objetivos ora pretendidos.

O primeiro deles reside na imposição de limitações à expropriação. Essa garantia tem como consequência a impossibilidade, ou imposição, de certos limites e procedimentos, para que um determinado sujeito possa ser alijado da titularidade de algo que se encontra legitimamente em seu domínio. Ele, inclusive e principalmente, manifesta-se em face de pleitos contrapostos ao seu, como titular da coisa, ainda que de natureza pública.

Tal princípio foi consagrado no artigo 17 da Declaração dos Direitos do Homem e do Cidadão de 1789, nos seguintes termos: “como a propriedade é um direito inviolável e sagrado, ninguém dela pode ser privado, a não ser quando a necessidade pública legalmente comprovada o exigir e sob condição de justa e prévia indenização"

Como se verá adiante, o referido princípio reverbera a concepção de Locke, no sentido de que tanto o direito de propriedade como o direito à vida e à liberdade constituem o fundamento da moralidade política:

Tendo, pois, propriedades quando em sociedade, cabe aos homens tal direito aos bens que lhes pertencem, que ninguém tem o direito de lhos tirar, em todo ou em parte, sem o seu consentimento; sem isso, não haveria nenhuma propriedade verdadeira, uma vez que outros tivessem o direito de tirá-la quando lhe aprouvesse, sem consentimento. (Locke, 2011, p. 94)

Em tópico específico sobre o tema, também será explicitado que Locke traz argumentos em torno da ideia de que haveria um legítimo interesse decorrente de um direito natural à propriedade.

A ideia de direito natural, de fato, não é tão clara. Locke, v.g., fundamenta a sua concepção a respeito do tema em aspectos religiosos ligados ao cristianismo; e, a partir de premissas de origem teológica, constrói a sua ideia de direito natural à propriedade 
privada. Principalmente, aliás, por tal razão, sua teoria de direito de propriedade é alvo de duros ataques de autores que buscam uma legitimidade laica, científica e objetiva.

Em que pesem as críticas dirigidas aos aspectos teológicos da teoria de Locke, deve-se reconhecer a importância dos aspectos morais que fundamentam o direito de propriedade. Na verdade, a ideia de direito natural, muito além da concepção de direitos inatos, carrega consigo a possibilidade de legitimação de direitos com fundamentos de natureza moral.

De fato, por mais que se almeje sistematizar, sob critérios científicos objetivos, uma concepção de propriedade, não há como não se considerar que uma ideia de propriedade como direito humano fundamental não se sustenta sem um sólido fundamento de natureza moral.

A perspectiva de direito natural de propriedade parece ser o cerne do artigo $17 \mathrm{da}$ Declaração Universal dos Direitos Humanos, ao prever que "todo ser humano tem direito à propriedade, só ou em sociedade com outros". Trata-se, portanto, de uma ideia de possibilidade, ou seja, de elegibilidade em relação à propriedade de algo, de que seriam titulares todos os seres humanos.

Tal direito, de certo modo, não garante que todo homem ou mulher é ou será proprietário de uma determinada coisa, mas, sim, que todo homem e toda mulher reúnem características intrínsecas que os permitem serem titulares desse direito de propriedade de algo.

Além disso, de tal perspectiva decorre a ideia de que, ao se prever essa elegibilidade como um direito intrínseco dos seres humanos, não seria possível a exclusão, de quem quer seja, dessa possibilidade de se tornar proprietário de algo. Em certa medida, por exemplo, a instituição de uma socialização da propriedade resultaria em uma clara violação ao direito natural de se tornar proprietário.

A propósito da ideia de elegibilidade, esclarece Waldron:

All it maintains is that there is something about human nature (the nature we all share) which makes it wrong to exclude any (or all) of us from the class of potential proprietors.

(Waldron, 2002, p. 21)

O referido direito tem sido defendido com base em fundamentos éticos que justificariam o domínio individual, ou o direito de se tornar proprietário. A propriedade tem sido defendida ante o anseio de se promover virtudes como a responsabilidade, 
prudência, autoconfiança e caridade. Igualmente, tem sido compreendido como um elemento importante de democracia, no sentido de permitir que, como resultado de efeitos que dele decorrem, possam os indivíduos experimentar um determinado grau de liberdade individual. Waldron, a propósito do tema, chega a afirmar que é por intermédio da propriedade que o cidadão passa a ter um lugar no mundo, onde ele possa se sentir confiante de que a sua liberdade será reconhecida e respeitada. (Waldron, 2002, p. 22)

Os fundamentos éticos do direito de propriedade, igualmente, podem ser encontrados em filósofos antigos, como Aristóteles, cuja teoria da virtude é, de certo modo, integrada pelo direito ao domínio de "bens exteriores" como um de seus elementos estruturantes. Nesse sentido:

$\mathrm{Na}$ verdade, ninguém porá em dúvida uma classificação dos bens que os divide em três grupos - os bens exteriores, os bens do corpo e os bens da alma, ou negará que os homens felizes devem tê-los todos. (Aristóteles, 1988, p. 219)

Mais adiante, conclui Aristóteles:

No momento, admitamos que a vida melhor, é a separadamente para cada indivíduo ou coletivamente para as cidades, é a vida conforme às qualidades morais e provida de meios suficientes para a prática de ações moralmente boas. (Aristóteles, 1988, p. 220/221)

A fundamentação do direito de propriedade em seu aspecto ético, posteriormente, foi utilizada por Hegel em sua teoria de propriedade, conforme se verificará adiante, em capítulo específico.

Neste momento, no entanto, o importante é reiterar que a ideia de direito de propriedade tem sido desenvolvida de forma umbilicalmente associada a perspectivas de desenvolvimento humano em seu aspecto ético e de virtude, permitindo o florescimento de autonomia, responsabilidade e liberdade.

Essa ideia traz em seu cerne a compreensão de que, se o direito de propriedade está associado ao desenvolvimento de tais aspectos, aqueles desprovidos de propriedade (não proprietários), igualmente, estariam privados de seu direito de se desenvolver eticamente no âmbito de determinada sociedade. Ou seja, estariam tolhidos de um pleno 
desenvolvimento de sua autonomia, responsabilidade e liberdade e, dessa forma, alijados de seus direitos políticos mais basilares.

A partir de tais premissas é que se fundamenta o pleito a um direito de caráter geral à propriedade (direito geral de propriedade), haja vista que, conforme explicita Waldron, "an equal concern, then, for the ethical development and autonomy of all dictates an equal concern that each individual should have property" (Waldron, 2002, p. 24)

Verifica-se, portanto, que a fundamentação para o alcance dos objetivos propostos parte da princípio de que o direito de propriedade deve ser compreendido na medida em que todos os seres humanos são a ele intitulados, exatamente por possuírem caracteres e pretensões muito peculiares que resultam na legitimidade do interesse em se tornar proprietário de algo. No decorrer do texto serão desenvolvidos argumentos de autores clássicos e modernos que justificam o ponto de vista ora explicitado.

O que se pretende, dessa forma, é reafirmar que a legitimação dos interesses que recaem sobre a sempre tormentosa questão da alocação de recursos, assim como o encontro (convergente ou não) desses interesses legitimados que incidem sobre a referida questão, deve ter na instituição da propriedade o seu locus.

Em termos práticos, objetiva-se propor uma análise sob outra perspectiva das discussões acerca de conflitos entre direito de propriedade e direito à subsistência; direito de propriedade e dignidade da pessoa; direito de propriedade e direito a um meio ambiente equilibrado; e, finalmente, direito de propriedade e acesso democrático aos recursos urbanísticos.

Tais conflitos, conforme se demonstrará adiante, são intrínsecos à discussão da própria legitimação do direito de propriedade. São questões internas à propriedade e, no âmbito dessa instituição, devem ser compreendidas, legitimadas e solucionadas, com instrumentos democráticos, que se coadunem com o seu perfil constitucional.

O modelo democrático de propriedade, portanto, pretende compreender o referido direito sob as tensões que decorrem dos conflitos de interesses que recaem sobre o exercício dos atributos do domínio. Analisando-se propriamente as tensões existentes, demonstrar-se-á que o processo democrático é o meio mais adequado para a legitimação de interesses e a consequente conformação do conteúdo da propriedade.

Para alcançar os objetivos pretendidos, será, inicialmente, apresentada a conceituação clássica do direito de propriedade que é amplamente aceita pela doutrina civilista brasileira. A explanação das teorias clássicas é necessária para se realizar o 
contraponto com o modelo que se pretende desenvolver. Assim, objetiva-se demonstrar as contradições existentes no modelo atualmente adotado na tradição do Direito Civil, como forma de superá-lo, em busca de um modelo consentâneo com os princípios e valores que norteiam o Estado Democrático de Direito.

Em seguida, serão desenvolvidos os fundamentos liberais do direito de propriedade. Almeja-se não apenas repassar os fundamentos da conceituação moderna da propriedade mas também destacar os aspectos ético-valorativos que contribuem para o desenvolvimento do seu perfil democrático.

De fato, conforme se demonstrará adiante, a propriedade, como direito a ser preservado por valores intrínsecos de titularidade do proprietário, tem profundo lastro nos ideais liberais relacionados à liberdade, autonomia e igualdade.

Os fundamentos ético-valorativos do liberalismo serão desenvolvidos, assim, como forma de propor a ideia de que a propriedade é um direito que deve ser preservado por valores próprios relacionados ao titular do domínio. A legitimidade da garantia da propriedade, assim, decorre de interesses individuais, que são constitucionalmente amparados, exatamente pela relevância do conteúdo valorativo que os compõe.

Além disso, os fundamentos liberais apresentados também nortearão a perspectiva de democracia que se pretende desenvolver para a delimitação do modelo democrático de propriedade.

Em seguida, serão apresentados, sob a égide do paradigma do Estado Social, os princípios que forjaram a ideia de função social da propriedade.

De fato, tendo o liberalismo clássico resultado em contradições e conflitos sociais e políticos relevantes, importantes correntes de pensamento foram desenvolvidas com o intuito de superá-lo. Nesse contexto, serão destacadas as contribuições de Marx, Comte e Durkheim, como profundos críticos do liberalismo e expoentes - cada um a seu modo - de novas perspectivas teóricas, a partir da consideração do contexto social e político vivenciado à época.

As contribuições dos referidos autores, como se sabe, demonstraram a inviabilidade do projeto do Código Napoleão de desenvolver uma ideia de propriedade de caráter absoluto e incondicionado. Nesse contexto, exsurge a relevante noção de função social da propriedade e a compreensão de que a propriedade deve ser limitada para o fim de atender a interesses de uma coletividade afetada pelo exercício dos atributos do domínio por seu titular. 
A perspectiva social do direito de propriedade é examinada, em seguida, pela compreensão de sua vinculação com o projeto utilitarista de alcançar uma perspectiva ética fundamentada na ideia de um bem comum. Nesse capítulo, serão analisadas as possibilidades e as limitações inerentes a teorias ético-valorativas que têm como norte as ideias de bem-estar social e maximização de felicidade (ou de riqueza).

Nesse sentido, serão exploradas as referidas perspectivas para o fim de se verificar como o conteúdo do direito de propriedade poderá ser conformado pela legitimação de pretensões coletivas relacionadas a um determinado fim social.

No capítulo seguinte, será explorada a ideia de constitucionalização do Direito Civil, notadamente o de propriedade, com o destaque para a experiência constitucional brasileira.

Objetiva-se alcançar, a partir de um breve histórico dos textos constitucionais brasileiros, cotejados com a contextualização política das respectivas assembleias constituintes, uma noção do perfil valorativo de nossa tradição (caracterizado por certo aspecto informe e dinâmico) que culminou com o texto constitucional de 1988, no que concerne ao direito de propriedade.

Por fim, postos os fundamentos (além de seus conflitos e tensões) que norteiam a perspectiva que se almeja apresentar em relação ao domínio, será proposto um modelo democrático de propriedade no contexto brasileiro.

Para tanto, inicialmente, será desenvolvida a compreensão, tendo como norte o trabalho de Jeremy Waldron, de que a propriedade privada se trata de um direito, com profundo lastro em valores relevantes e legitimados, em nosso caso, pelo texto constitucional.

Em seguida, serão apresentados avanços em relação à teoria de Jeremy Waldron, notadamente com suporte nos trabalhos desenvolvidos por Joseph Singer, para o fim de se alcançar a compreensão do modelo democrático de propriedade.

Por último, promover-se-á uma análise da atuação do Judiciário brasileiro notadamente do Supremo Tribunal Federal - vis-à-vis as ideias de propriedade e democracia, tendo como vetor três casos relevantes sobre o tema, julgados em nossa Corte Constitucional. 


\section{A conceituação clássica do direito de propriedade no Brasil}

As reflexões no Brasil acerca do direito de propriedade têm se pautado, em sua ampla maioria, pela visão herdada da tradição civilista da Europa continental. Essa perspectiva tem por fundamento a concepção moderna de direito de propriedade desenvolvida entre os séculos XVIII e XIX, que culminou com a edição do Código Civil francês.

Não se deve desconsiderar, no entanto, que tal perspectiva foi fortemente influenciada pelas tradições romanísticas de Direito Civil. ${ }^{2}$ Incontáveis institutos e instrumentos jurídicos foram herdados dos romanos e, posteriormente, desenvolvidos, teorizados e adaptados às novas realidades sociais, econômicas e políticas da Europa ocidental.

A propósito de tal herança, não é despiciendo enfatizar a forma pragmática com a qual os romanos desenvolveram o seu Direito. Eles, como é de conhecimento comum, prescindiam de definições e esquematizações teóricas para o desenvolvimento de seu Direito Civil e de sua regular utilização. Não há, portanto, o surgimento, concomitante à origem das formas e instrumentos jurídicos, de uma teoria específica para o instituto do direito de propriedade.

Não houve, portanto, o desenvolvimento de uma teoria que desse arrimo à criação dos instrumentos que tinham a função de proteger o referido direito. De fato, apenas a partir da Idade Média é que os juristas se preocuparam em tentar desenvolver, buscando nas difusas fontes do Direito Romano, o racional teórico do instituto.

Dessa forma, com fundamento no Digesto (I, 5, pr.), deduziu-se que a propriedade seria o ius utendi et abutendi re sua (direito de usar e de abusar da coisa sua); e de outro dispositivo do Digesto (I, 5, pr.), que trata de liberdade, extraiu-se o entendimento de que a propriedade seria a naturalis in re facultas eius quod cuique facere libet, nisi si quid aut ui aut iure prohibetur (faculdade natural de se fazer o que se quiser sobre a coisa, exceto aquilo que é vedado pela força ou pelo direito). (Alves, 2014, p. 293)

Esse modelo romano de pensamento acerca do instituto da propriedade, a partir das sistematizações desenvolvidas por Justiniano, no âmbito do Corpus Iuris Civilis, influenciou fortemente o pensamento dos juristas modernos.

${ }^{2}$ A propósito, Caio Mário da Silva Pereira é expresso: “a raiz histórica do nosso instituto da propriedade vai-se prender no Direito Romano" (Pereira, 2014, p. 68) 
De fato, a relevante influência de tais concepções foi retratada expressamente no âmbito do Código Civil napoleônico. Nesse sentido, o artigo 544 do Código - que inspirou as nossas codificações - também não abandonou a tradição de descrever a propriedade por meio da especificação dos seus atributos (Grossi, 2006, p. 79): ${ }^{3}$

544. A propriedade é o direito de gozar e dispor das coisas da maneira mais absoluta, desde que não sejam utilizadas de uma forma proibida pelas leis ou estatutos.

A leitura do referido dispositivo nos remete, de pronto, a duas características importantes. A primeira delas, já mencionada, diz respeito à descrição da propriedade por meio da especificação dos seus poderes, a partir do ponto de vista das prerrogativas do titular do referido direito. $\mathrm{O}$ segundo aspecto nos leva à conclusão no sentido de que o legislador, à época, houve por bem reforçar o direito de propriedade - principalmente diante do poder político - atribuindo-o caráter "absoluto". É manifesta a preocupação do legislador em resguardar os poderes de disposição da coisa, de que são titulares os proprietários, diante dos interesses que porventura pudessem incidir sobre ela.

Apesar da relativização constante da parte final do dispositivo, de fato, a expressão "da maneira mais absoluta" se revela demasiado significativa para as pretensões de origem burguesa almejadas pela Revolução Francesa no contexto político que resultou na referida codificação. A propósito do tema, o historiador do Direito, Paolo Grossi, traz interessantes apontamentos:

Imputamos a uma leitura acrítica do artigo o casulo retórico a que o problema histórico-jurídico da propriedade foi consignado, mas foi afirmação injusta: mais do que todo o texto do artigo, encheram-se-nos os ouvidos com a hipérbole

\footnotetext{
${ }^{3}$ Não se quer defender que a tradição romanística de direito de propriedade foi, simplesmente, transportada para o regime instaurado pela Revolução Francesa. Evidentes são as distinções, seja em relação ao conteúdo, propriamente dito, das concepções acerca do direito de propriedade, seja em relação aos contextos políticos em que foram cunhadas. Não se insere, todavia, como objeto do presente estudo, a realização de um escorço histórico acerca da evolução do conteúdo do direito de propriedade. Nada obstante, no que concerne às relações entre o direito de propriedade romano e o francês moderno, oportuno se faz revisitar os apontamentos de Paolo Grossi: "Que queremos, então, dizer? Que o Código é um produto de antigo regime? Certamente não. Queremos somente constatar que sob o tremular das novas bandeiras a velha mentalidade jurídica encarnada em uma certa construção do sistema dos direitos reais não foi de todo apagada, e coexiste desarmonicamente com a nova ideologia oitentaenovista da qual claramente o Código é portador; talvez mais no nível inconsciente (que é o típico das mentalidades), todavia os velhos esquemas interpretativos e construtivos, os velhos arsenais técnicos, demonstram a sua extraordinária aderência aos ossos e ao coração desses homines novi, e o sistema do direito codificado revela algumas significativas desfiaduras, algumas não desmentíveis incoerências." (Grossi, 2006, p. 80)
} 
vibrante que revestia "de la manière la plus absolue" os conteúdos dos poderes proprietários, e não se pretendeu nada mais. Não há dúvida, porém, de que o mesmo artigo contém claramente uma dupla escritura; de um lado agiganta-se ao infinito a galhardia dos poderes; do outro esboça-se, atenuando, uma lista de poderes determinados: gozar e dispor (Grossi, 2006, p. 78)

O novo modelo proprietário instituído pelo Código Civil napoleônico tinha por objetivo resguardar as pretensões econômicas da burguesia emergente. Pretendia-se, portanto, que a propriedade se consubstanciasse em um instrumento simples, funcional, amplamente protegido por e contra o Estado, que fosse eficiente no propósito da circulação de riqueza.

Da mesma forma, os ideais iluministas de natureza individualista foram contemplados na ideia de que a propriedade seria caracterizada por uma relação absoluta (ou quase) entre o sujeito e objeto, qualificada por amplíssimos poderes daquele sobre este.

Sobre esse aspecto, novamente, esclarecedores são os apontamentos de Paolo Grossi:

Síntese de poderes, não tem nada a compartilhar com poderes individuais sobre a coisa: é um poder supremo de qualidade diversa que os compendia a todos e os supera pondo o instituto que a encarna acima das grosseiras forças econômicas; de sua natureza sintética adquire o traço inconfundível da simplicidade. O direito real limitado é aqui somente um acidente que pode interferir na sua vida, porém sempre do exterior e sempre e somente sobre a projeção da eficácia sem nenhuma possibilidade incisiva sobre o monólito proprietário. A propriedade e o ius in re aliena pertencem a dois universos sustentados por razões diversas e opostas; são, sobre o plano lógico e histórico, dois dados antitéticos.

A característica principal, portanto, desse novo modelo de propriedade, reside exatamente no objetivo de se atribuir efeitos quase absolutos a essa relação entre sujeito e objeto. As limitações que incidiriam nessa relação pretensamente absoluta - quase que 
"acidentalmente", como diria Paolo Grossi - decorrem de fatores externos e, muitas vezes, contrapostos às pretensões do proprietário individual.

Essa perspectiva na qual se fundamenta o modelo proprietário moderno, reiterese em benefício da ênfase, teve por objetivo promover os interesses da emergente burguesia - ou do homo oeconomicus, como ironicamente diria o historiador em referência - em desenvolver o principal instrumento sobre o qual se fundamenta o sistema econômico capitalista. Nesse sentido, assevera Paolo Grossi:

Como a afirmação de uma liberdade e de uma igualdade formais tinham sido os instrumentos mais idôneos para garantir ao homo oeconomicus a desigualdade de fato das fortunas, assim essa propriedade "espiritualizada" teria se concretizado, por graça das suas ilimitadas possibilidades transformistas, na pedra filosofal da civilização capitalista: a mais pobre, a mais desencarnada das construções jurídicas terse-ia demonstrado um meio eficientíssimo para transformar tudo em ouro, instrumento pontual para todo tipo de mercantilização" (Grossi, 2006, p. 83)

É evidente que, com a evolução das relações sociais, políticas e econômicas, desde o advento do Código Civil napoleônico, a propriedade sofreu importante impacto. De fato, as pretensões, à época de seu surgimento, como acima ressaltado, se voltavam para o reforço do poder individual de decisão acerca da disponibilidade da coisa. A burguesia deveria ter poderes quase que irrestritos para decidir o destino daquilo que compunha o seu domínio.

É de se notar, a propósito, que a nossa codificação de 1916, além das influências do liberalismo francês, também absorveu forte impacto do denominado pejorativamente "liberalismo tardio" alemão, consubstanciado no $B G B$, tido - em uma análise superficial, diga-se de passagem - como uma codificação de características liberais-burguesas. (Rodrigues Júnior, 2013)

A partir da Revolução Industrial, bem como das demandas sociais, notadamente da classe trabalhadora, que a sucederam, outros interesses passaram a incidir sobre o direito de propriedade, exigindo a sua conformação.

Nesse contexto, exsurge a revolucionária concepção de propriedade trazida por Karl Marx e Friederich Engels, segundo a qual o direito de propriedade estaria 
intimamente associado às relações econômicas, em determinada sociedade, que acabam por moldar (no âmbito de seu conceito de infraestrutura e superestrutura) as relações políticas e sociais. Nessa linha, em Grundrisse, Karl Marx assevera:

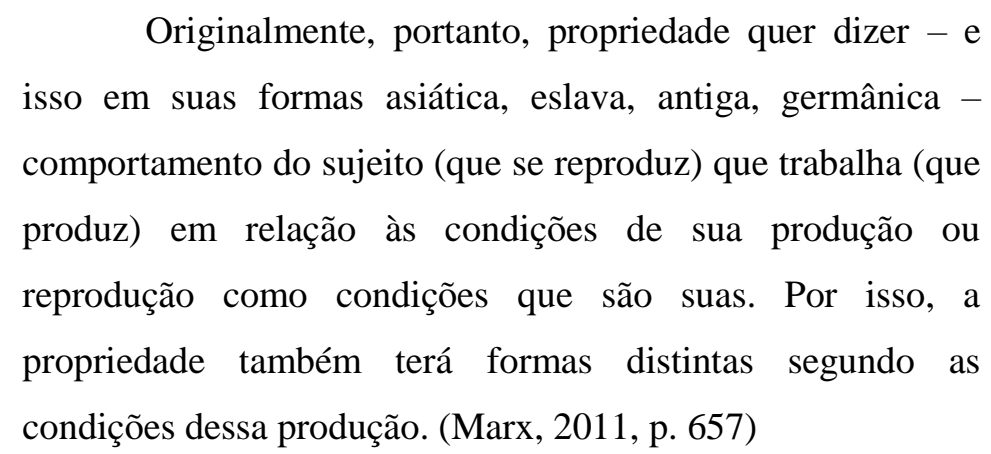

Em razão da necessidade de se conformar o direito de propriedade a uma nova realidade econômica e social, o caráter pretensamente absolutista passa a sofrer severas mitigações. Interesses sociais e princípios de ordem pública forçaram o direito de propriedade a se adaptar. Sob a ameaça de se suprimir o direito individual de disposição da coisa, em detrimento da atribuição de tal prerrogativa a uma coletividade (ou grupo de pessoas identificadas politicamente para tanto), por força de revoluções comunistas, o direito de propriedade sofreu significativas concessões que resultaram em limitações à mencionada pretensão absolutista.

Diante das evoluções sociais e com o desenvolvimento do sistema capitalista (e o ocaso dos principais regimes comunistas), outros interesses também resultaram em impactos no direito de propriedade. No âmbito das sociedades ocidentais, a partir do período pós-guerra, com o advento dos chamados Direitos Humanos de terceira e quarta geração, diversos outros pleitos sociais pressionaram, igualmente, o caráter absolutista e individualista do direito de propriedade. Houve, portanto, a imposição de mais uma série de limitações às prerrogativas individuais, com o intuito de se contemplar os legitimados direitos emergentes.

Surgem, portanto, processos limitadores do direito de propriedade individual, com vistas a contrapor os seus aspectos individualistas com diversas pretensões de ordem pública, sejam elas relacionadas a interesses de natureza trabalhista, ambiental, urbanística, entre inúmeros outros. Caio Mário da Silva Pereira esclarece da seguinte forma o referido fenômeno: 
$\mathrm{Na}$ verdade, crescem os processos expropriatórios, sujeitando a coisa à utilidade pública e aproximando-a do interesse social. Condiciona-se o uso da propriedade predial a uma conciliação entre as faculdades do dono e o interesse do maior número; reduz-se a liberdade de utilização e disposição de certos bens; sujeita-se a comercialidade de determinadas substâncias no interesse da saúde pública; obriga-se o dono a destruir alguns bens em certas condições. De certo modo os legisladores e os aplicadores da lei em todo o mundo, segundo afirma Trabucchi, mostram-se propensos a atenuar a rigidez do direito de propriedade. (Pereira, 2014, p. 70)

A esse fenômeno de incidência de direitos e interesses sobre o conteúdo da propriedade, de modo a resultar em uma transformação do direito de propriedade em um instrumento para o alcance de determinados objetivos de ordem pública atribui-se a ideia de funcionalização do direito de propriedade. Reconhece-se o direito de propriedade, com todos os seus atributos, mas seu conteúdo é condicionado por uma, ou mais, funções, $\mathrm{da}(\mathrm{s})$ qual(ais) decorre(m) limitações às prerrogativas individuais. (Lima, 2010, p. 32)

A ideia de funcionalização do direito de propriedade está intimamente ligada à constitucionalização do Direito Civil. Trata-se de um tema extremamente relevante na delineação contemporânea de seu conteúdo, razão pela qual a ele será dedicado um capítulo específico.

O importante, neste momento, é enfatizar que, no modelo clássico de domínio, em suas versões mais contemporâneas, reconhece-se o direito de propriedade sob uma perspectiva individualista, que, em função dos interesses acima mencionados, torna-se limitada por vetores externos oriundos de uma determinada atuação do Estado.

Em síntese, portanto, compreende-se que a propriedade não é um direito absoluto - como, aliás, o próprio Código Civil napoleônico o reconhece, ao limitá-lo aos "regulamentos" -, apesar de seu caráter individualista, em virtude de várias limitações incidentes, em decorrência das limitações legais e administrativas que incidem sobre ela.

No âmbito de tal perspectiva, o modelo clássico de domínio tende a definir o direito de propriedade a partir dos atributos e prerrogativas de que dispõe o titular do domínio. Tanto autores clássicos quanto outros contemporâneos, com algumas variações, sob a referência do texto do Código Civil, trazem definições muito semelhantes ao 
conceito romano consubstanciado na expressão: dominium est ius utendi et abutendi, quatenus iuris ratio patitur.

Nessa linha, v.g., explicita Caio Mário da Silva Pereira:

O nosso Código Civil não dá uma definição de propriedade, preferindo enunciar os poderes do proprietário (art. 1228): "O proprietário tem a faculdade de usar, gozar e dispor da coisa, e o direito de reavê-la do poder de quem quer que a injustamente a possua ou detenha".

Fixando a noção em termos analíticos, e mais sucintos, dizemos como tantos outros, que a propriedade é o direito de usar, gozar e dispor da coisa, e reivindicá-la de quem injustamente a detenha. (Pereira, 2014, p. 75)

Maria Helena Diniz, na mesma linha, considera que a melhor solução para conceituar o direito de propriedade seria reduzir a propriedade aos seus elementos essenciais positivos, por entender que essa opção tem por base, segundo a referida autora, o conteúdo da propriedade, pois enuncia os poderes do proprietário. Nesse sentido, assevera:

Poder-se-á definir, analiticamente, a propriedade, como sendo o direito que a pessoa física ou jurídica tem, dentro dos limites normativos, de usar, gozar e dispor de um bem, corpóreo ou incorpóreo, bem como de reivindicá-lo de quem injustamente o detenha. (Diniz, 2004, p. 115)

Entre os mais recentes, mencione-se, ainda, a conceituação de Flávio Tartuce, que, apesar de se manter fiel à tradição civilista de fundamentar a conceituação do direito de propriedade em seus atributos, insere outros aspectos decorrentes da perspectiva constitucional do Direito Civil (adiante aprofundada):

Assim, a propriedade é o direito que alguém possui em relação a um bem determinado. Trata-se de um direito fundamental, protegido no art. $5^{\circ}$, inc. XXII, da Constituição Federal, mas que deve atender a uma função social, em prol de toda a coletividade. A propriedade é preenchida a partir dos 
atributos que constam do Código Civil de 2002 (art. 1228), sem

perder de vista outros direitos, sobretudo aqueles com substrato

constitucional. (Tartuce, 2016, p. 119)

Examinando as definições acima transcritas acerca do direito de propriedade, podemos chegar a algumas conclusões que caracterizam, portanto, uma determinada linha de pensamento que congrega a doutrina civilista tradicional. Em princípio, poder-se-iam elencar três elementos fundamentais que estão presentes nas mencionadas definições e, pontualmente, nas mais recentes, um quarto aspecto elementar.

O primeiro elemento fundamental diz respeito à tradição de se definir a propriedade pela relação do sujeito com um determinado objeto. Ou seja, o liame jurídico que caracteriza o direito real de propriedade seria formada por um determinado sujeito, titular do domínio, uma determinada coisa apropriada e um vínculo jurídico entre o sujeito e o objeto. Essa perspectiva decorre da tradição de se contrapor a definição de direitos reais e de direitos obrigacionais, a partir da caracterização dos primeiros como sendo aqueles identificados por uma relação jurídica entre um sujeito e um objeto, e os segundos como aqueles marcados por uma relação entre dois ou mais sujeitos, por força da qual são estabelecidos um direito de crédito, a uma das partes da relação, e uma respectiva sujeição, da outra parte, a um determinado dever correlato ao direito de crédito.

O segundo aspecto se refere à qualificação dessa relação entre sujeito e objeto pela descrição dos poderes de que são titulares os proprietários. Nesses termos, o conteúdo do direito de propriedade seria preenchido, apenas e tão somente, por seus atributos relativos ao sujeito titular do domínio. A respeito desse aspecto, é de se notar que o caráter individualista da doutrina tradicional se reforça, mais uma vez, pelo enfoque na enumeração das prerrogativas disponíveis ao titular do direito sobre o objeto do seu domínio.

O terceiro elemento por vezes está subjacente à definição literal, explícita, como, v.g., no Código Civil napoleônico, e diz respeito ao reconhecimento da existência de limites externos às prerrogativas que preenchem o conteúdo do direito de propriedade.

A doutrina tradicional, portanto, de um lado, descreve os poderes que caracterizam o direito de propriedade e, de outro, os contrapõe às limitações externas advindas de normas legais, administrativas ou contratuais. Como exemplos de limitações externas, poder-se-ia mencionar as seguintes: (i) a vedação ao uso abusivo da propriedade; (ii) a vedação ao uso nocivo; (iii) prescrição aquisitiva; (iv) direitos de vizinhança; (v) direitos 
reais sobre coisas alheias; (vi) direitos do locatário; (vii) direitos do condômino; (viii) bem de família; (ix) alienação da propriedade em garantia e (x) restrições contratuais.

Tal elemento é fundamental exatamente por se partir do pressuposto de que, com a imposição de limitações, é que se alcançarão os objetivos pretendidos pelas características funcionais da propriedade. De fato, chega-se a afirmar que a mitigação do absolutismo da propriedade, por meio da imposição de limites ao direito de propriedade, viabilizará o alcance de uma pretensão de "socialização", de modo a fazer com que a propriedade atenda aos interesses coletivos, em detrimento dos individuais. (Araújo, 2007)

Por fim, o último elemento suscitado, notadamente nas definições de autores mais atuais, refere-se à função social da propriedade, por observância do artigo $5^{\circ}$, inciso XXIII, da Constituição Federal, que dispõe que "a propriedade atenderá a sua função social".

A função social da propriedade, tal como é apresentada pela doutrina tradicional, também serve de um vetor limitador a exercer pressão sobre o conteúdo da propriedade. A partir dessa concepção, as prerrogativas individuais, por força do próprio texto constitucional, devem ser limitadas por eventuais imposições externas decorrentes dos efeitos concretos da incidência do princípio da função social da propriedade.

Pela relevância do tema, e dado o seu caráter constitucional, o princípio da função social da propriedade será abordado em tópico específico no capítulo sobre a constitucionalização do Direito Civil no Brasil.

Em que pese a relevância da definição de propriedade desenvolvida pela tradição civilista, tal modelo de se compreender o referido direito não está imune a críticas.

A propósito do tema, Waldron, fazendo referência à teoria de Honoré, especifica que o que se denomina, no Brasil, o conteúdo de propriedade, seriam, nada mais, do que incidentes-padrão, como, por exemplo: (i) direito de possuir; (ii) direito de usar; (iii) direito de gerenciar (ou seja, a prerrogativa de determinar como outros podem usar); (iv) o direito de perceber os frutos decorrentes do uso por outros; (v) o direito à percepção do valor capital da coisa; (vi) o direito a garantias contra a expropriação; (vii) o direito de dispor da coisa, por venda, doação, ou testamento; (viii) o dever de se abster de usar a coisa de modo a lesar terceiros; (ix) a responsabilidade patrimonial em decorrência de eventuais julgamentos que poderão resultar em execução da coisa e (x) a expectativa de que quando determinados direitos de outros sobre a coisa se extinguirem, a coisa retornará ao seu titular em sua plenitude. (Waldron, 2002, p. 49) 
Nada obstante, Waldron critica a conceituação da propriedade a partir do que ele denomina de incidentes-padrão, exatamente em razão da falta de constância da extensão, profundidade e mesmo existência de tais características, quando se leva em consideração um universo maior de variações sociais. Nesse sentido, assevera:

If that were all, there would be no problem of definition: private property would be a bundle of rights, but if it remained constant for all or most of the cases that we want to describe as private property, the bundle as a whole could be defined in terms of its content. But, of course, it does not remain constant, and that is where the difficulties begin. (Waldron, 2002, p. 28)

Por essas razões, portanto, uma compreensão adequada do direito de propriedade não prescinde de uma análise dos fundamentos que o lastreiam no direito brasileiro. Para tal finalidade, uma mera explicitação dos seus atributos não é suficiente, notadamente, para justificar, sob perspectivas políticas, morais e econômicas, os motivos pelos quais o direito pátrio prevê a decisão individual como um elemento essencial na alocação de recursos

Faz-se necessário, portanto, um aprofundamento nos fundamentos filosóficos e políticos que sustentam o direito de propriedade, com vistas a se estabelecer uma perspectiva democrática sobre o direito de propriedade, à luz da Constituição Federal de 1988. 


\section{Fundamentos liberais do direito de propriedade}

\subsection{Locke, propriedade e democracia}

3.1.1. Breves linhas a respeito de Locke e seu pensamento

Inicialmente, é necessário registrar que grande parte dos revisores atuais das teorias de Locke reproduz uma análise simplificadora que tem como premissa uma classificação de seu pensamento como um produto de uma concepção de direito natural enviesada por sua fixação teológica, que retrataria o status quo da visão de mundo vigente em seu tempo.

Locke, por vezes, é retratado - de forma diminuta, diga-se de passagem - como um autor que tem como premissa a legitimação filosófica de uma estrutura política e social então dominante, sem maiores pretensões de transcender filosoficamente a mera reprodução de princípios cristãos em questões políticas e sociais.

É fato que alguma de suas posições - como, v.g., concepções sobre a colonização da América $^{4}$-, se analisadas sob uma perspectiva a-histórica, descontextualizada, portanto, e sob perspectivas atuais, poderiam reforçar esse tipo de compreensão limitadora de suas teorias.

Um exemplo clássico do que ora se assevera refere-se ao seu posicionamento em relação a questões de gênero. De fato, como nos demonstra Jeremy Waldron, Locke se esforçou, de forma relevante, para alcançar um posicionamento a respeito de tais discussões sobre gênero que muito destoaria das perspectivas então vigentes (Waldron, 2002, p. 22). Ora, se para alcançar os ideais que norteiam a sua teoria política pressupõese um apego radical à igualdade entre seres humanos, Locke não poderia deixar de formular e defender, também, a sua própria concepção de igualdade entre os sexos. Não obstante, no dizer do autor acima mencionado, "he did not succeed in this to the satisfaction of modern feminists" (Waldron, 2002, p. 23).

4 "Não pode haver demonstração mais clara disso do que várias nações da América, que têm abundantes terras, mas são carentes de todos os confortos da vida. A eles a natureza forneceu tão liberalmente quanto a qualquer outro povo todas as condições para a abundância, isto é, solo fértil capaz de produzir em quantidades qualquer alimento, agasalho e diversão; entretanto, por falta de benfeitorias pelo trabalho, não possuem nem um centésimo das conveniências de que gozamos. E lá, um rei de território grande e fértil se alimenta, mora e veste-se pior que um trabalhador diarista na Inglaterra" (Locke, 2011, p. 37) 
É necessário reconhecer, no entanto, alguns contrapontos importantes formulados por Locke a respeito do tema, em relação ao ideário então vigente. É digna de nota, nesse contexto, a refutação expressa por Locke de uma suposta legitimidade na superioridade masculina com o argumento - que fundamentaria essa tese - de que a criação de Eva teria se dado a partir de uma "parte" do corpo de Adão. Para Locke, claramente, a igualdade entre homem e mulher residiria no fato de que ambos (e não apenas o homem) reproduziriam a imago dei.

A propósito do tema, se, de um lado, Locke reconhece uma autoridade conjugal do homem em relação à sua consorte, de outro, (i) refuta que tal autoridade deveria decorrer da força e (ii) legitima essa circunstância apenas e tão somente no livre consentimento. Locke defende que até poderia ser possível a escolha da autoridade como fundamento em algum tipo de habilidade que legitimaria essa posição. No entanto, essa habilidade poderia ser invocada apenas como um fundamento para se outorgar o consentimento, sem o qual a autoridade não teria qualquer legitimidade.

Em referência à temática de igualdade de gêneros, segundo Locke, esclarecedoras são as conclusões de Jeremy Waldron:

I have no tidy resolution to offer. Locke's position on the natural subjection of wives is an embarrassment for his general theory of equality. (...)

They [as posições de Locke] confirm my hunch with which I began, that we what have here is a philosopher struggling not altogether successfully to free his own thought as well as the thought of his contemporaries form the idea that something as striking as the difference between the sexes must count in itself as a refutation of equality. (Waldron, 2002, p. 40)

Em síntese, o que virá de Locke é o seu constante esforço para estruturar a sua teoria política em torno de uma visão radical de igualdade entre os seres humanos. Isso não impede, todavia, que a sua empreitada seja ora mais bem sucedida, ora menos, haja vista, evidentemente, o contexto no qual o seu pensamento está inserido.

O que se requer, portanto, é um empenho intelectual para se analisar as teorias de Locke de uma forma desvencilhada das amarras simplificadoras das classificações, de certo modo preconceituosas, que o reduzem a um direito natural teológico que busca 
legitimar o status quo vigente. Como diria Waldron, "perhaps it is time someone explored the theological foundations of Locke's egalitarianism on a basis that is sympathetic to his approach or at least not actively hostile to the view that a theory of equality might actually need theological foundations". (Waldron, 2002, p. 15)

\subsubsection{Locke e a sua concepção de igualdade (o intelecto democrático)}

A concepção de igualdade de Locke é fundamentada no entendimento de que os seres humanos são iguais entre si, em virtude da detenção de uma capacidade (modesta) intelectual - a de formar e manipular ideias abstratas, que permitem que uma determinada pessoa racionalize a existência de Deus e a necessidade de descobrir o que Ele requer dela (Waldron, 2002, p. 83). É o que Jeremy Waldron denomina de the democratic intellect.

A igualdade basilar, para Locke reside, portanto, exatamente nessa rasa capacidade intelectual de racionalizar e abstrair, de modo que ninguém tem a obrigação, seja alto ou baixo, homem ou mulher, rico ou pobre, inteligente ou menos esclarecido, de ser submetido ao Poder Político de outrem sem o seu consentimento.

É importante destacar que, para Locke, a mais alta capacidade intelectual não estaria associada a nenhum grau de superioridade em relação a pessoas desprovidas de tais capacidades. Ao contrário, Locke tem uma visão bastante negativa de seus pares da filosofia que levantam questões e múltiplas discussões, nunca chegando a uma conclusão clara, sendo, dessa forma, propícios a aumentar as dúvidas e alimentar, ao final, um certo ceticismo. Por vezes, Locke se demonstra muito mais simpático às contribuições morais dos integrantes da classe trabalhadora do que em relação aos colegas integrantes de uma elite intelectual.

A propósito do tema, esclarece Jeremy Waldron:

(...) despite Locke's own vocational respect for intellectual excellence, he does not fall into the trap of differentiating humans in their merit or moral or political standing by the sophistication of their intellects. The properties on which his theory of equality is grounded are matched by the properties that he respects, and which he regards as socially and politically sufficient for a practical grasp of morality. 
Em que pesem as refutações de Locke a uma ideia de superioridade intelectual, é necessário enfatizar que a formulação de igualdade está diretamente relacionada à racionalidade, mais especificamente ao que ele denomina de racionalidade corporal (ou corporificada). A questão da igualdade, portanto, fundamenta-se na capacidade humana de pensar, racionalizar e agir em conformidade com os seus próprios desígnios, decorrentes da atividade de racionalização e abstração. Para Locke, tais capacidades integram mais um aspecto da formação, no homem, da imago dei, que, em sua concepção, constitui um dos pilares da ideia de igualdade.

A fundamentação dessa ideia na capacidade humana de racionalizar resulta em consequências importantes, notadamente em relação àqueles desprovidos desse tipo de capacidade, como os que possuem algum tipo de deficiência intelectual, v.g., os "loucos", “idiotas", etc. Para Locke, esses jamais poderão ser reputados como homens livres, pois não terão a possibilidade de dispor de seu livre arbítrio, exatamente pela falta de capacidade de entendimento de si como seu próprio guia.

Não obstante, essa mesma consequência não deve ser replicada em relação às crianças, que, segundo o referido autor, devem ser tratadas como se iguais fossem, haja vista que teriam, em tese, a capacidade potencial de racionalizar de modo a se enquadrar, ainda que em um momento posterior, no conceito de intelecto democrático.

Enfatize-se que a ideia de igualdade, em Locke, não está sujeita a gradações intelectuais. Para tal finalidade, basta uma modesta capacidade de racionalização e de abstração, as quais, como ele defende, estão presentes em todos os seres humanos. Afinal, o maior ou menor grau de capacidade intelectual estaria relacionada exatamente ao esforço e treinamento, o que nada interfere no princípio de igualdade por ele defendido.

De fato, para Locke, a "linha de corte", o que define os limites de seu conceito de igualdade, é exatamente a capacidade de racionalização e abstração. Consoante o referido autor, os animais possuem a capacidade de atuar segundo ideias advindas diretamente dos seus sentidos. Não possuem, no entanto, a capacidade de abstração para racionalizar a partir de ideias gerais.

Não se trata, propriamente, de um limite rígido e perfeitamente estabelecido. Há, na verdade, um determinado espectro que contém limites, de certo modo, compreensivos. Ao final, Locke insiste que o ser humano detém uma capacidade intelectual suficiente e satisfatória para alcançar os propósitos estipulados por Deus. Por mais inadequado e imperfeito que possa parecer o intelecto humano, a capacidade de compreender é suficiente para o cumprimento das obrigações morais do homem, de modo que "não 
haveria desculpa para um determinado servo não atender aos seus compromissos à luz de vela, por não dispor da luz solar"; pois, nas palavras de Locke, "the Candle that is set up in us shines bright enough for all our purposes". (Locke, 2015, p. 45)

Para Locke, portanto, qualquer pessoa com a capacidade de abstração pode racionalizar a existência de Deus, bem como relacionar a ideia de Deus com os propósitos e deveres inspirados Nele, de modo a poder se conduzir em conformidade com as leis que lhes são aplicáveis.

O fato de determinada criatura ter alcançado a referida capacidade intelectual resulta na existência de uma relação especial moral com Deus. Uma pessoa que conhece a existência de Deus e, portanto, está em posição de responder por seus atos perante Ele, qualifica-se a partir de uma existência caracterizada por um especial significado, pois foi enviada ao mundo pela vontade e desígnios de Deus. (Waldron, 2002, p. 80)

A propósito do tema, Jeremy Waldron dá o seguinte exemplo: quando eu pego um coelho, eu sei que não estou diante de uma criatura que detém uma capacidade de abstração e, portanto, eu sei que aquela criatura não se trata de um dos servos especiais de Deus, enviado ao mundo para cumprir os seus desígnios. Por outro lado, se eu pego um ser humano, eu tenho a consciência de que estou lidando com uma criatura dotada da capacidade de abstração e de conhecimento de Deus e seus propósitos. Portanto, deverei tratar a referida pessoa como Sua propriedade, fruto de Sua obra, devendo me abster de destruí-la, machucá-la ou explorá-la. (Waldron, 2002, p. 80)

Esse é, portanto, o fundamento que define o espectro de capacidades intelectuais que caracteriza o cerne da concepção de igualdade para Locke.

Por mais que não se possa dissociar a concepção de igualdade de Locke de uma perspectiva eminentemente religiosa, mais especificamente cristã, não se deve desconsiderar a sua relevante influência no âmbito da filosofia moderna. Com as devidas considerações e reflexões a respeito do contexto histórico no qual a teoria de Locke foi desenvolvida, podemos encontrar relevantes aspectos de seu trabalho em autores atuais.

A propósito do tema, é digna de ser considerada a proposta teórica de John Rawls a respeito dos seus ideais de igualdade, liberdade e justiça. Para ele, a ideia de liberdade e igualdade está relacionada a dois poderes morais, in verbis:

One such power is the capacity for a sense of justice: it is the capacity to understand, to apply, and to act from (and not 
merely in accordance with) the principles of political justice that specify the fair terms of social cooperation;

The other moral power is a capacity for a conception of good: it is the capacity to have, to revise, and rationally to pursue a conception of good. Such a conception in an ordered family of final ends and aims which specifies a person's conception of what is of value in human life or, alternatively, of what is regarded as fully worthwhile life. The elements of such a conception are normally set within, and interpreted by, certain comprehensive religious, philosophical, or moral doctrines in the light of which, the various ends and aims are ordered and understood. (Rawls, 2001, p. 18/19)

Realizados, portanto, os devidos apontamentos a respeito dos diferentes contextos históricos, bem como das perspectivas fundadas em teorias teológicas, verificase que importantes elementos podem ser coletados dos trabalhos de Locke, com vistas a provocar importantes reflexões às sempre atuais problemáticas relacionadas à liberdade, igualdade e democracia.

\subsubsection{A teoria de direito de propriedade em Locke}

A teoria de propriedade de Locke deve ser compreendida no âmbito de sua perspectiva de Direito Natural, entendendo-se, como tal, uma constelação de direitos e deveres que Deus produziu no universo (S. Alexander \& M. Peñalver, 2012, p. 36). Tais leis naturais são aplicáveis e acessíveis a todos os seres humanos, em razão das capacidades de abstração e racionalização advindas do "intelecto democrático", acima explorado. Referidas normas, direitos e deveres que antecedem a qualquer forma de consentimento e arranjo político, econômico ou social.

A propósito, na introdução do capítulo sobre propriedade em seu Segundo Tratado sobre o Governo, Locke delineia os fundamentos da sua concepção de um direito natural do homem à propriedade:

Quer levemos em conta o direito que os homens têm, depois de nascidos, à própria preservação, como nos dita a razão natural, e portanto, ao alimento, à bebida e a tudo que a 
natureza oferece para a subsistência, quer consideremos a revelação, que nos enumera as concessões feitas por Deus a Adão, a Noé e seus filhos, fica patente que Deus, conforme diz o rei Davi (SL 113,24) 'deu a terra aos filhos dos homens', concedendo-a em comum a todos os homens. (Locke, 2011, p.

E acrescenta:

Esforçar-me-ei para demonstrar como os homens podem chegar à propriedade de partes daquilo que Deus deu à Humanidade em comum, e sem a necessidade de um pacto lavrado entre os membros da comunidade. (Locke, 2011, p. 29)

Desse último excerto extraem-se importantes premissas a respeito da teoria de Locke: (i) a concepção de Locke está associada a perspectivas teológicas; (ii) o direito de propriedade decorre - ao menos em algum momento - de uma situação de propriedade comunitária; (iii) o direito à propriedade é um direito natural, prescindindo, portanto, de qualquer consentimento entre os seres humanos e (iv) o direito à aquisição da propriedade é um direito de que dispõem todos os seres humanos.

Basicamente, a teoria de Locke a respeito de propriedade é centrada em seu conceito de "mistura" entre uma determinada coisa e o trabalho. Para Locke, as coisas encontram-se, inicialmente, em seu estado natural, no qual estariam sujeitas à apropriação de quem quer que seja, desde que determinada pessoa empregue o seu trabalho para, efetivando uma mistura dele (o trabalho) com a coisa, produza algo distinto do estado natural daquela coisa.

No estado natural, portanto, prevalece uma espécie de direito comunitário, no qual todas as pessoas teriam um potencial direito à apropriação. A propriedade privada surgiria, apenas, em ato subsequente e na medida em que determinada pessoa empregasse o trabalho para modificar a coisa, retirando-a de seu estado natural.

Em suas próprias palavras, esclarece Locke como funcionaria o processo de apropriação e de surgimento da propriedade privada:

"Embora a terra e todos os seus frutos sejam de propriedade comum a todos os homens, cada homem tem uma propriedade particular em sua própria pessoa: a esta ninguém 
tem qualquer direito senão ele mesmo. $\mathrm{O}$ trabalho de seus braços e a obra das suas mãos, pode-se afirmar, são propriamente dele. Seja o que for que ele retire da natureza no estado em que lho forneceu e no qual o deixou, mistura-se e superpõe-se ao próprio trabalho, acrescentando-lhe algo que pertence ao homem, e, por isso mesmo, tornando-o propriedade dele. Retirando-o do estado comum em que a natureza o colocou, agregou-lhe com seu trabalho um valor que o exclui do direito comum de outros homens. Uma vez que esse trabalho é propriedade exclusiva do trabalhador, nenhum outro homem tem direito ao que foi agregado, pelo menos quando houver bastante e também de boa qualidade em comum para os demais" (Locke, 2011, p. 30)

No cerne da discussão sobre propriedade em Locke está a ideia de que os seres humanos são propriedade de Deus. Os indivíduos foram colocados no mundo para cumprir com os desígnios de Deus. Nesse sentido, os seres humanos têm um dever inerente de autopreservação, assim como, igualmente, também têm o dever de ajudar os outros a se preservarem. Nessa linha, e partindo do pressuposto de que todos os seres humanos têm deveres a serem cumpridos perante Deus, na mesma medida, estariam, então, em iguais condições, intitulados a se apropriar, usar e gozar das coisas necessárias para a sua autopreservação.

O estado natural, para Locke, portanto, em muito se assemelha a um estado de coisas em que prevalece um direito comunitário ao acesso e à apropriação dos bens encontrados na natureza. Os homens, em igualdade de condições, teriam o acesso e a possibilidade de se apropriar, segundo os critérios de igualdade traçadas por Locke e anteriormente sintetizados.

Locke, no entanto, objetiva estipular alguns critérios e premissas para caracterizar essa apropriação de coisas que se encontra no estado natural, pois, segundo ele, "a mesma lei da natureza que nos dá acesso à propriedade, também a limita”. A primeira dessas limitações reside no seu posicionamento contrário à apropriação seguida da destruição dolosa de bens e/ou o seu desperdício, pois "Deus nada criou para o homem desperdiçar e destruir”. (Locke, 2011, p. 32)

Em segundo lugar, tal como anteriormente explicitado, o direito de apropriação existe ao menos "quando houver bastante e também de boa qualidade em comum para 
os demais" (Locke, 2011, p. 29). Trata-se, portanto, de uma limitação fundamentada na ideia de igualdade e na concepção de que o direito à apropriação, ainda que potencial, não poderia ter caráter excludente, haja vista que, conforme acima explicitado, o dever de autopreservação decorre da própria lei natural e dos desígnios de Deus projetados para cada um dos seres humanos.

Em terceiro, há que se mencionar um importante aspecto da teoria de Locke que está relacionado ao que se denomina de princípio da caridade, explicitado de forma bastante precisa por Jeremy Waldron:

This is a principle of charity, a principle which requires property-owners in every economy to cede control of some of their surplus possessions, so that they can be used to satisfy the pressing needs of the very poor, when the latter have no way of surviving otherwise. (Waldron, 2002, p. 177)

O princípio da caridade, portanto, é fundamentado na posição política de Locke de que todo homem tem um direito natural à sua subsistência, não sendo lícito, dessa forma, que o direito à apropriação seja levado a efeito de modo a tolher o referido direito.

O segundo estágio no processo de apropriação se caracteriza pelo surgimento do dinheiro e da troca de bens. A troca e a monetarização seriam mecanismos utilizados pelo homem para evitar o desperdício (spoilation proviso). De fato, na medida em que a troca e a circulação de dinheiro permitiram a diminuição do desperdício, de outro modo, propiciaram o acúmulo de riqueza e, em decorrência, os desequilíbrios na apropriação de bens.

Em um argumento extremamente polêmico e sujeito a críticas de toda natureza, Locke defende que a criação do dinheiro refletiria, na verdade, uma espécie de consentimento expresso ou tácito dos homens em relação à acumulação de riqueza e os desequilíbrios decorrentes:

E uma vez que o ouro e a prata têm pouca utilidade para a vida humana, se comparados com o alimento, vestuário e transporte, sendo seu valor apenas consensual entre os homens, enquanto é o trabalho que dá em grande parte a medida das coisas, é evidente que os homens concordaram com a posse desigual e assimétrica da terra, tendo descoberto, pela aceitação tácita e espontânea, a maneira de alguém possuir licitamente 
mais terra do que aquela cujo produto pode utilizar, recebendo em troca, pelo excesso do produto, ouro e prata que pode guardar sem causar dano aos outros, uma vez que estes metais não se deterioram nem se estragam. Os homens viabilizaram tal divisão desigual de posses à margem da sociedade sem precisar de acordos especiais, atribuindo valor ao ouro e à prata, e concordando tacitamente sobre o uso do dinheiro; e havendo governos, as leis regulam o direito de propriedade, e constituições positivas determinam a posse da terra. (Locke, 2011, p. 42)

A propósito do referido argumento, Jeremy Waldron tem relevantes apontamentos. Ora, Locke não poderia passar incólume à contundente crítica no sentido de que o consentimento a que se alude no excerto acima transcrito não passa de uma utopia, haja vista que os mais desfavorecidos com a distribuição desigual de riqueza seriam os menos aptos a participarem de convenções a respeito do valor da moeda em curso e, da mesma forma, estariam menos envolvidos nas decisões econômicas a respeito da mensuração do valor do ouro e prata.

Ainda assim, aponta Waldron, é importante reconhecer o esforço de Locke no sentido de (ao menos tentar) justificar os desequilíbrios na distribuição de riqueza em argumentos relacionados à igualdade entre os homens. De fato, ainda que a argumentação seja frágil, é relevante destacar que Locke objetiva legitimar o seu ponto de vista a partir de critérios de consentimento, o que apenas faz sentido em contextos de liberdade e igualdade. (Waldron, 2002, p. 177)

O terceiro estágio na teoria de Locke seria a constituição da sociedade civil. Esse estágio decorreria das inseguranças e dos conflitos resultantes da introdução do dinheiro e da pouca capacidade de sociedades, ainda em estado natural, de resolverem tais conflitos.

O alcance do estágio de constituição de uma sociedade civil não implica na mitigação dos direitos e deveres existentes no âmbito da lei natural. Ao contrário, ela estipularia os limites das convenções, da autoridade e do poder, no âmbito da sociedade civil. No que concerne à propriedade privada, igualmente, o governo instituído não poderia suprimir direitos existentes no estado natural, razão pela qual a propriedade 
adquirida legitimamente, sob a égide das premissas da lei natural, não poderia ser retirada de seu titular sem o seu consentimento.

No estágio da constituição da sociedade civil, o aspecto do consentimento tornase fundamental. Para que seja possível a efetivação de um sistema normativo que regule o direito de propriedade, a presença do consentimento é condição sine qua non para a teoria de Locke. Nesse contexto, em relação à problemática da imposição de tributos, Locke entende que todo aquele que desfruta da proteção do Estado deve pagar por uma parcela do custo de sua manutenção. Ainda assim, entretanto, deverá a referida taxação ser legitimada pelo consentimento, seja expresso ou por meio de representantes eleitos pelos cidadãos. (S. Alexander \& M. Peñalver, 2012, p. 45)

Em conclusão, o cerne da teoria de Locke reside em um direito especial (segundo a classificação de Waldron) à propriedade privada. Basicamente, o argumento em torno do processo de apropriação poderia ser assim sintetizado:

(i) Um homem que trabalha em um objeto mistura o seu trabalho com aquele determinado objeto;

(ii) O homem é o detentor de seu trabalho que ele mistura com o objeto;

(iii) O objeto passa a conter algo que pertence ao trabalhador;

(iv) Portanto, expropriar o objeto do controle do trabalhador sem o seu consentimento é uma forma de expropriar o trabalho de determinada pessoa sem o seu consentimento. Dessa forma, tal conduta consistiria em uma violação ao direito referido no item "ii" acima;

(v) Por essa razão, ninguém poderá retirar o objeto do trabalhador sem o seu consentimento;

(vi) Diante disso, o objeto deve ser reconhecido como propriedade do trabalhador. (Waldron, 2002, p. 184)

De fato, são, em síntese, dois os argumentos utilizados por Locke para justificar a propriedade privada (e o processo de apropriação) em relação à determinada coisa, notadamente (i) o conceito de mistura do trabalho com o objeto e (ii) a premissa de que a apropriação privada é a única forma de se suprir as necessidades humanas, especificamente de autopreservação, como uma decorrência do cumprimento dos desígnios de Deus.

Tal como nos aponta Waldron, os dois argumentos, analisados sob uma perspectiva contemporânea, são de certo modo bastante frágeis para justificar um sistema de propriedade privada. Nada obstante, não se pode negar a relevância que vários aspectos 
da teoria de Locke ainda têm no âmbito do processo dinâmico de construção do conteúdo do direito de propriedade.

3.2. Liberdade como fundamento do direito de propriedade: a concepção de Kant

3.2.1. Os fundamentos morais da teoria de Kant a partir da ideia de liberdade

É importante que se enfatize, desde já, que o objeto do presente estudo não é, propriamente, a análise da teoria moral de Kant. O objetivo específico deste item é estabelecer, sinteticamente, os principais pontos de partida do referido autor, com o intuito de melhor clarificar a ideia de direito de propriedade de Kant.

Tal análise, ainda que sintética, faz-se necessária, todavia, considerando que toda a teoria de Direito de Kant é baseada em suas concepções e inter-relações entre as ideias de moralidade, razão e liberdade.

De fato, Kant parte do pressuposto, em sua teoria, de que a lei moral é pura, por se tratar de um princípio apriorístico que tem origem única e exclusivamente em uma razão livre. Nesse sentido, defende que a plena consciência da pureza da lei e de sua origem em nossa personalidade livre e autônoma é a certeza da proteção contra a violação da lei moral. (Rawls, 2003, p. 147)

A razão se torna livre na medida em que ela é capaz de determinar a vontade alheia a qualquer aspecto externo à própria razão. Qualquer decisão que seja fundamentada em circunstância outra, não será considerada, portanto, livre e, consequentemente, qualificada sob os critérios de universalidade que a valoram moralmente. Nesse sentido:

Ora, é impossível pensar uma razão que com a sua própria consciência recebesse de qualquer outra parte uma direção a respeito dos seus juízos, pois que então o sujeito atribuiria a determinação da faculdade de julgar, não à sua razão, mas a um impulso. Ela tem de considerar-se a si mesma como autora dos seus princípios, independentemente de influências estranhas; por conseguinte, como razão prática ou como vontade de um ser racional, tem de considerar-se a si mesma como livre; isto é, a vontade desse ser só pode ser uma vontade própria sob a ideia da liberdade, e, portanto, é preciso 
atribuir, em sentido prática, uma tal vontade a todos os seres racionais. (Kant I. , 2011, p. 102)

A teoria moral de Kant não intenta discernir o que é certo ou errado (legítimo ou ilegítimo) sob a perspectiva da lei moral. Diferentemente, o que ele pretende é explicitar a origem da moralidade em uma razão pura, autônoma e livre. A plena consciência desse princípio resultaria em um desejo natural do homem de agir em conformidade com a lei moral que ele, livre, racional e autonomamente, criou para si.

Kant, portanto, objetiva analisar os princípios a partir dos quais seria norteada a conduta do homem plena e idealmente racional, ainda que em divergência com os seus desejos e inclinações contingentes, de modo a estabelecer uma lei moral a ser objetivamente aplicada.

$\mathrm{Na}$ concepção de Kant, um arbítrio bom é um arbítrio que determina as ações a partir da ideia racional de dever, dissociada de inclinações e desejos. As ações determinadas pelo dever são moralmente valorosas por seu fundamento no princípio da vontade, e não em razão de seus propósitos (objetivos ou fins) decorrentes dos resultados almejados.

A ideia racional de dever moral é consubstanciada no imperativo categórico, que representa um dos principais pilares da teoria moral kantiana. A propósito do tema, John Rawls procura sistematizar um procedimento (categorical imperative procedure) cujo desenvolvimento resulta na aplicação do imperativo categórico. (Rawls, 2003, p. 167).

Segundo o referido procedimento, inicialmente, um agente racional estabelece uma máxima. Na teoria kantiana, uma máxima diz respeito a uma proposição subjetiva de conduta (Kant, 2016, p. 34) racionalmente válida para um determinado agente que a propõe para si, de forma individual, com o intuito de determinar as suas próprias ações. Em seguida, a referida máxima é generalizada, para o fim de ser aplicada indiscriminadamente a todos os seres humanos dotados de razão. A regra de conduta, portanto, deixa de ser subjetiva para se tornar objetiva e aplicável erga omnes. Em um terceiro momento, a regra de conduta (agora tornada uma lei prática, pelo seu caráter objetivo) deve ser transformada em uma lei da natureza, resultando no seguinte preceito: "todos sempre farão X nas circunstâncias C de modo a obter Y, como uma lei natural" (Rawls, 2003, p. 168). Por fim, a lei natural criada seria analisada com o objetivo de se obter o entendimento a respeito dos seus efeitos na ordem da natureza, em conjunto com as demais leis naturais. 
A partir do mencionado procedimento, portanto, é possível a realização da evolução de uma máxima em um imperativo categórico. A propósito da diferenciação desses dois conceitos, Kant esclarece o seguinte:

A regra prática é sempre um produto da razão, porque ela prescreve como visada a ação enquanto meio para um efeito. Mas para um ente, cuja razão não é total e exclusivamente o fundamento determinante da vontade, essa regra constitui um imperativo, isto é, uma regra que caracterizada por um dever-ser, o qual expressa a necessitação objetiva da ação e significa que, se a razão determinasse totalmente a vontade, a ação ocorreria inevitavelmente segundo essa regra. Portanto, os imperativos valem objetivamente e diferem totalmente das máximas enquanto proposições fundamentais subjetivas. (Kant, 2016, p. 34)

O imperativo categórico, por sua vez, refere-se a uma proposição fundamental que é decorrente de uma determinação racional da vontade livre que independe de qualquer circunstância contingente e de circunstanciais resultados práticos para determinar a sua validade e aplicabilidade. A esse respeito, Kant afirma que:

As últimas [leis] têm que determinar a vontade enquanto vontade, ainda antes que eu pergunte se realmente tenho a faculdade requerida para um efeito apetecido ou que coisa que me importa fazer para produzi-lo; por conseguinte elas têm de ser categóricas, do contrário não são leis; porque lhes falta a necessidade que, se deve ser prática, tem que ser independente de condições patológicas, por conseguintes, de condições contingentemente aderentes à vontade. (Kant, 2016, p. 35)

A partir dessa concepção a respeito de imperativo categórico, defende o autor, da seguinte forma, o princípio elementar de sua teoria moral:

"O princípio supremo da moral é, portanto: age de acordo com uma máxima que pode valer ao mesmo tempo 
como lei universal. - Toda máxima que não se qualifica para tanto é contrária à moral. (Kant I. , 2014, p. 29)

Kant, portanto, parte da compreensão do homem como um ser racional, capaz de formular uma proposição fundamental de conduta (uma máxima) pura e livre de qualquer aspecto contingente. Essa proposição teria a sua legitimidade e validação verificadas a partir do critério da universalização e da objetivação da máxima formulada, de modo que a proposição pudesse, a partir de sua aplicabilidade erga omnes, ser considerada como uma lei prática. Se a conduta de um determinado agente estiver em conformidade com a lei prática universal, a partir dos referidos critérios de validação, será ela considerada como virtuosa do ponto de vista da moralidade.

Para o fim ora almejado, é fundamental destacar que a teoria moral de Kant está intrinsecamente relacionada à ideia de liberdade. A lei moral, para o referido autor, é a lei da liberdade. De fato, a lei moral é desenvolvida e aplicada, tão-somente, em virtude do desenvolvimento da razão prática pura e da autonomia, que fundamentam a ideia de espontaneidade absoluta da qual decorre uma plena liberdade da capacidade de se estipular a orientação da conduta humana. A razão prática pura tem a possibilidade de construir o fim almejado, autonomamente, de acordo, apenas, com ideais racionais.

As deliberações devem partir da firme convicção de que os julgamentos que determinarão a conduta humana estão absolutamente livres e independentes de qualquer aspecto empírico ou contingencial, devendo obediência, unicamente, aos preceitos elaborados exclusivamente a partir de critérios racionais. O poder da razão, nesse sentido, deve determinar as deliberações sem a influência de aspecto externo à racionalidade, pois, segundo Kant, "se nos deixarmos levar a transformar em princípio moral algo proveniente da última fonte [a experiência], expomo-nos aos erros mais grosseiros e perniciosos" (Kant I. , 2014, p. 16)

A propósito da fundamentação da lei moral na ideia de liberdade, como produto de uma razão prática pura, esclarece Kant que:

(...) a razão pura pode ser prática - isto é, pode determinar por si a vontade independentemente de todo o empírico -, e isto na verdade mediante um factum, no qual a razão pura deveras se prova em nós praticamente, a saber, a autonomia na proposição fundamental da moralidade, pela qual ela determina a vontade do ato. - Ela [a Analítica de Kant, em 
Crítica da Razão Prática] mostra ao mesmo tempo que este factum vincula-se indissoluvelmente à consciência da liberdade da vontade, antes, é idêntico a ela (...). (Kant I. , 2016, p. 67)

Nesse sentido, a liberdade é um conceito puro da razão e, portanto, não pode ser alcançada a partir de elementos empíricos ou contingenciais (Kant I. , 2014, p. 23). Da mesma forma, tratando-se de um produto da razão prática pura, a lei moral não terá outra fonte se não a própria liberdade. A partir de tal perspectiva, é que Kant fundamenta o seu conceito de pessoa, sob o ponto de vista moral:

Pessoa é aquele sujeito cujas ações são passíveis de uma imputação. A personalidade moral nada mais é, portanto, do que a liberdade de um ser racional sob leis morais (enquanto a psicológica é meramente a faculdade de se tornar consciente da identidade de si mesmo nos diversos estados de sua existência), do que se segue então que uma pessoa não está submetida a outras leis senão àquelas que ela mesma se dá (ou só ela ou ao menos simultaneamente com outros). (Kant I. , 2014, p. 26)

Em conclusão, é importante reforçar que, para Kant, mais do que tentar explicitar o que seria bom ou ruim (legítimo ou ilegítimo) do ponto de vista moral, o fundamental é compreender a lei moral como um produto da razão prática pura, desenvolvida, autonomamente, por um legislador universal que tem a liberdade necessária para definir, de forma absolutamente espontânea, a regra de conduta que deverá orientar as suas ações. A lei moral, nesse sentido, é uma consequência lógica da liberdade humana. Assim, Kant explicita que "se, pois, se pressupõe liberdade da vontade, segue-se daqui a moralidade com o seu princípio, por simples análise do seu conceito" (Kant I. , 2011, p. 100)

3.2.2. A perspectiva kantiana sobre direito de propriedade

3.2.2.1. A liberdade como direito natural e o princípio universal do direito

Como visto anteriormente, as perspectivas sobre direito de propriedade em Locke e em Hegel estão associadas ao entendimento da propriedade como uma extensão da individualidade humana. 
Kant, diferentemente, fundamenta a sua teoria na liberdade individual, compreendida como a "independência do arbítrio coercitivo de um outro" (Kant I. , 2014, p. 42). A liberdade, no entanto, pode subsistir com a liberdade de qualquer outro segundo a lei universal. Trata-se, na perspectiva kantiana, como o único direito originário, "pertencente a cada homem por força de sua humanidade" (Kant I. , 2014, p. 43).

Reconhece-se, efetivamente, que a igualdade entre os homens também é inata. No entanto, o seu fundamento, para Kant, é, da mesma forma, a ideia de liberdade:

A igualdade inata, i.e., a independência que consiste em não ser obrigado por outros a mais do que podem também ser obrigados reciprocamente; portanto, a qualidade do homem de ser seu próprio senhor (sui juris), assim como a de um homem irrepreensível (justi), porque não foi injusto com ninguém antes de qualquer ato jurídico (...). (Kant I. , 2014, p.

A ideia de liberdade não está associada a nenhum aspecto instrumental (ou finalístico), ou seja, o seu reconhecimento como direito inato a ser devidamente garantido não depende de nenhuma demonstração de que a sua defesa resultará em alguma utilidade, bem-estar social ou desenvolvimento humano. $\mathrm{O}$ direito à liberdade é um fim em si mesmo, pois decorre de uma característica humana intrínseca de liberdade de escolha fundamentada na racionalidade que é própria e comum a todos os seres humanos.

De fato, conforme visto acima, um dos fundamentos da teoria moral de Kant é a possibilidade de se universalizar uma determinada regra de conduta (ou direito). A universalização, portanto, é o critério primordial de validade na teoria de Kant. Nesse sentido, qualquer aspecto empírico que fundamente o direito ou a regra de conduta, incluindo o direito à felicidade, bem-estar social, entre outros, não teria a sua validade reconhecida, exatamente em virtude de seu caráter contingencial. Apenas a liberdade, fundamentada na racionalidade humana, é universal.

É importante reconhecer, todavia, que o direito à liberdade, por si só, não é suficiente para regular as relações humanas. Esse direito é suficiente para garantir, tão somente, o direito universal do homem a buscar os seus próprios propósitos a partir de seu próprio corpo. É, portanto, insuficiente para se garantir, na prática, a defesa de interesses e direitos existentes na complexidade e na variedade das relações humanas. $\mathrm{Ou}$ 
seja, o direito inato à liberdade precisa, por meio da razão, ser implementada na prática, no mundo exterior.

Nesse contexto, é que surgiu o sistema de direito privado, como uma forma de se estabelecer racionalmente, e a partir da lei universal, mecanismos (inclusive de coação/execução) que possam resultar na efetividade da liberdade de escolha. Da mesma forma, com vistas a garantir a efetividade da autonomia e a liberdade individual, surge a necessidade de se estabelecer o direito público e a ideia de Estado.

\subsubsection{Direito à propriedade privada e direitos adquiridos}

A perspectiva de direito de propriedade em Kant está intimamente ligada à sua proposição de lei universal, acima explicitada, como uma extensão prática da lei maior da razão pura. O direito de propriedade decorre, assim, de postulado jurídico da razão prática, que se fundamenta na ideia de que o "meu de direito" é aquilo a que estou ligado de tal maneira que o uso que um outro quisesse dele fazer sem meu consentimento haveria de me lesar. (Kant I. , 2014, p. 51)

Nesse sentido, o direito de propriedade fundamenta-se na liberdade, como único direito inato, na medida em que representa um direito a usar e dispor de um objeto externo como um instrumento de alcance de um determinado fim autonomamente escolhido. De fato, para Kant, a impossibilidade de utilização do objeto para o fim escolhido livremente seria, efetivamente, uma privação da liberdade, in verbis:

Mas, se porventura fazer uso do mesmo simplesmente não estiver juridicamente em meu poder, i. é, não puder coexistir com a liberdade de qualquer um segundo uma lei universal (for injusto), então a liberdade se privaria a si mesma do uso de seu arbítrio em vista de um objeto dele, por colocar fora de toda possibilidade de uso os objetos úteis, i. é, por aniquilá-los de um ponto de vista prático e torná-los sem dono (res nullius), mesmo que o arbítrio no uso das coisas concordasse formalmente (formaliter) com a liberdade externa de qualquer um segundo leis universais. (Kant I. , 2014, p. 52)

Para defender essa formulação, é necessário entender que o direito de propriedade pode se referir a um "meu externo" ou a um "teu externo". Deve-se compreender que 
qualquer objeto externo sujeito a escolhas, portanto, é passível de submissão ao arbítrio meu ou de outrem. A razão prática, portanto, não poderia compreender um objeto do arbítrio sujeito a uma proibição absoluta de seu uso, porque isso seria uma contradição da liberdade externa consigo mesma. (Kant I. , 2014, p. 52)

A propósito do tema, e como uma consequência lógica da proposição da lei universal, bem como partindo da premissa de se tratar de uma proposição racional e apriorística, assim Kant define a ideia de "meu e teu externo":

A definição nominal, i. é, aquela que basta meramente para a distinção do objeto em relação a todos os outros e resulta de uma exposição completa e determinada do conceito, seria: o meu externo é aquilo fora de mim cujo uso arbítrio somente me pode ser obstado com lesão (prejuízo de minha liberdade que pode coexistir com a liberdade de qualquer um segundo uma lei universal). (Kant I. , 2014, p. 55)

A ideia, portanto, de meu e teu externo, ou seja, de ter algo fora de mim como meu decorreria de uma ligação jurídica da vontade do sujeito com um determinado objeto segundo o conceito de posse inteligível, uma posse que independe da relação entre o sujeito e o objeto no espaço e no tempo (distinguindo-se, dessa forma, da posse meramente física).

Kant faz uma diferenciação entre a posse sensível e a inteligível. A sensível seria aquela em que há uma relação física do sujeito com o objeto. Diferentemente, a inteligível seria o que Kant denomina de posse jurídica da coisa, caracterizada por ser uma posse sem detenção (detentio). A proteção do meu e teu externo incluiria, portanto, o direito de defesa da posse inteligível de alguma intervenção injusta por parte de um determinado agente, não titular do domínio da coisa.

O direito de submeter algo ao arbítrio de uma determinada pessoa está, igualmente, associado a uma lei permissiva que confere, paralelamente, uma autorização de impor a todos os outros uma obrigação de se absterem do uso de certos objetos a cujo arbítrio de alguém foram atribuídos (Kant I. , 2014, p. 53). A propósito dessa importante concepção, vale destacar, portanto, que Kant não compreende como válida (ou lógica) uma relação jurídica (ou moral) entre o sujeito e um objeto determinado. A relação de direito, consubstanciada na referida lei permissiva, se constitui entre um sujeito e os 
demais; ou seja, a obrigação de abstenção, fundamentada na liberdade e no consentimento mútuo, conforme adiante será explicitado, é oponível erga omnes.

Kant, em sua teoria, nega que possa haver um direito de um sujeito sobre uma coisa, exatamente por pressupor que, se assim o fosse, dever-se-ia reconhecer que uma coisa pudesse ter uma obrigação para com o sujeito e, somente daí, derivar o direito em relação a todo possuidor dela, o que, segundo o referido autor, seria uma maneira de pensar absurda. (Kant I. , 2014, p. 69)

A concepção de direito de propriedade, de Kant, nesse sentido, tem como ponto de referência a relação entre o sujeito titular do domínio e os não proprietários, e como tais atores se relacionam de modo a promover e respeitar a liberdade de um determinado sujeito de escolher o seu próprio fim, a partir da exteriorização da autonomia e livre arbítrio em um determinado objeto.

O direito real (jus reale) não se trata, dessa forma, de direitos de seu titular em relação a uma coisa. A propósito da impossibilidade de se considerar um direito sobre um determinado objeto, Kant utiliza o seguinte argumento:

Mas é claro que um homem que estivesse inteiramente sozinho sobre a Terra não poderia adquirir ou ter como sua nenhuma coisa externa, porque entre ele, como pessoa, e todas as outras coisas externas, como coisas, não existe de forma alguma uma relação de obrigação. Logo, não existe também um direito (direto) sobre uma coisa, entendido em sentido próprio e literalmente, mas apenas é chamado assim aquilo que compete a alguém em relação a uma pessoa que se encontra na posse comum com todos os outros (no estado civil). (Kant I. , 2014, p. 69)

Esse dever de abstenção imposto é, evidentemente, recíproco. Ou seja, na pretensão de submeter outrem a uma sujeição de abstenção está implícita, ao mesmo tempo, a admissão de estar reciprocamente obrigado a uma abstenção proporcional em relação a todos os outros em vista do seu externo, pois a obrigação procede aqui de uma regra universal da relação jurídica externa. (Kant I. , 2014, p. 63)

Disso decorre outro aspecto fundamental na teoria kantiana (que será melhor explorado no tópico seguinte). Ora, se partimos da premissa de que precisamos nos sujeitar, igualmente, assim como os demais, a uma abstenção proporcional para promover 
e permitir a liberdade alheia de ter algo externo como seu, precisamos, igualmente, compreender como será resolvida a questão da violação da liberdade, ou seja, da ofensa ao dever de abstenção. Como se deve, portanto, lidar com a questão da coação para que seja possível, na prática, implementar o dever recíproco de abstenção?

Para responder à referida, pergunta Kant recorre à necessidade de se implementar um estado civil. Consoante o referido, autor, portanto, ter algo externo como seu somente é possível num estado jurídico, sob um Poder Legislativo público; portanto, no estado civil (Kant I. , 2014, p. 63).

Diante do exposto, e em conclusão à síntese ora apresentada em relação à concepção kantiana, poder-se-ia formular que, para Kant, propriedade privada seria "aquilo que submeto a meu poder (segundo a lei da liberdade externa) e em relação a que tenho a faculdade de fazer como objeto de meu arbítrio (conforme postulado da razão prática).” (Kant I. , 2014, p. 66)

3.2.2.3. Direito de propriedade, o pressuposto do estado civil e suas consequências

Como visto acima, a concepção de direito de propriedade em Kant pressupõe a existência de um estado civil que, regido por um Poder Legislativo público, detém o monopólio dos instrumentos de coação necessários para a promoção da liberdade individual em face de eventuais violações.

A ideia de que o estado civil é um pressuposto para o reconhecimento do direito de propriedade, em verdade, integra a última fase, de um total de três, de uma evolução conceitual que integra a teoria de Kant.

A divisão em fases não retrata, é importante destacar, uma evolução histórica de atos que se sucedem no tempo. Trata-se de uma divisão conceitual que culmina com a implementação de um estado civil organizado que, legitimado pela vontade universal, concretiza o anseio por liberdade.

A primeira fase, acima sintetizada, diz respeito à formulação do princípio universal do direito, derivado do imperativo categórico e suas diferentes formulações, cuja máxima estipula a coexistência da ação de uma pessoa com a liberdade do outro, sob o domínio de uma lei universal.

Nessa etapa inicial, demonstra-se a liberdade como único direito inato universal. Ela consiste na independência da ação/vontade do agente em relação a limitações por 
ações alheias, na medida em que essa liberdade é consistente com a de todos os demais. É, a priori, interna e diz respeito à autonomia conferida aos homens para alcançar os propósitos autonomamente escolhidos. Em princípio, portanto, a autonomia, nessa primeira fase, é adstrita às limitações de atuação do próprio corpo do agente.

Tal como anteriormente explicitado, dessa primeira fase não decorre direta e imediatamente, $a b$ initio, nenhuma consequência externa ao próprio homem; ou seja, a lei universal, por si só, não trata de direito de propriedade e suas consequências. Ela, no entanto, é integrada por certos atributos relacionados à igualdade, à autonomia, razão livre e o princípio da não dependência.

O direito de propriedade, como também visto acima, está relacionado à exteriorização da liberdade individual. Diz respeito, portanto, ao direito de se utilizar de coisas externas ao corpo humano para alcançar os fins autonomamente escolhidos pelo homem, em compatibilidade com a liberdade conferida aos demais para alcançar os respectivos propósitos.

A exteriorização, portanto, da liberdade individual, de modo a ultrapassar os limites do corpo humano para alcançar coisas externas (o meu e o teu externo) e delas se extrair a faculdade de utilização em conformidade com um determinado fim, constitui a segunda fase da concepção de direito de propriedade em Kant.

Nesse momento (conceitualmente compreendido) se insere a ideia de aquisição originária em Kant. A aquisição originária, por sua vez, é integrada pelas seguintes etapas: (i) apreensão do objeto que não pertence a ninguém - pois, caso pertencesse, estar-se-ia diante de uma violação ao princípio universal do direito - consubstanciada em uma posse fenomênica (possessio phaenomenon); (ii) declaração da posse do objeto, que, em verdade, se caracteriza como a manifestação ao mundo externo do apossamento da coisa, de modo a submeter a coisa ao arbítrio de seu possuidor e, assim, viabilizar o dever de abstenção dos demais; (iii) apropriação da coisa, como ato de uma vontade universal e externamente legisladora, pelo qual o outro é obrigado à concordância com meu arbítrio. Esse último momento é o que viabiliza a posse jurídica (inteligível), na classificação acima demonstrada. (Kant I. , 2014, p. 66)

É importante destacar que a aquisição originária, no estado natural, revela uma tensão relevante. De fato, o postulado da razão prática se revela em uma vontade do agente - autônoma e unilateral - exteriorizada na apropriação da coisa. Os efeitos dessa vontade unilateral, consubstanciada na posse jurídica, devem ser observados por todos, em conformidade com o dever universal de abstenção, decorrente do direito inato à 
liberdade. Nesse contexto, portanto, surge um aparente conflito prático entre o princípio de igualdade, implícito na lei universal, e o unilateralismo que caracteriza a vontade e a ação do agente que se apropria da coisa, pois, como consignado por Kant, "como originária, essa aquisição também é apenas consequência de arbítrio unilateral; pois, se fosse exigido para tanto um arbítrio bilateral, seria ela derivada do contrato de duas (ou mais) pessoas, portanto do seu de outros" (Kant I. , 2014, p. 67)

A possibilidade de adquirir algo, portanto, é consequência imediata do postulado da razão prática. A aquisição decorrente, tão somente, de um ato de vontade unilateral, no entanto, carece de legitimação suficiente para justificar um dever geral de abstenção por parte do não proprietário. Nesse sentido, essa vontade não pode legitimar, por si só, uma aquisição externa, a não ser na medida em que está contida no que Kant denomina de vontade unificada a priori, ou seja, pela unificação do arbítrio de todos aqueles que podem chegar a uma relação prática uns com os outros. (Kant I. , 2014, p. 71).

A legitimação do direito de propriedade, portanto, requer, além da vontade unilateral de aquisição, uma vontade, no dizer de Kant, onilateral, unificada, não de forma contingente, mas a priori, consubstanciando-se, assim, em uma vontade legisladora, "pois somente segundo esse princípio da vontade é possível a concordância do arbítrio livre de cada um com a liberdade de qualquer um, portanto um direito em geral, e assim também um meu e teu externo" (Kant I. , 2011, p. 72).

Dessa forma, a tensão acima referida - decorrente de uma aparente ausência de legitimação na aquisição originária fundada em um ato de vontade unilateral, suficiente a impor uma obrigação de abstenção de caráter erga omnes - somente pode ser mitigada no âmbito de um estado civil (e - acrescentamos, desde já, com necessária ênfase - na medida da capacidade desse estado civil de concretizar-se nessa vontade onilateral unificada).

A terceira fase conceitual de Kant, na constituição da propriedade privada, fundamenta-se, dessa forma, na viabilização do estado civil, pois "tão somente numa constituição civil pode ser algo adquirido peremptoriamente, enquanto no estado de natureza apenas provisoriamente". (Kant I. , 2014, p. 72)

A propósito da necessidade da legitimação do direito de propriedade no âmbito de um estado civil, esclarece Kant o seguinte:

O título racional da aquisição somente pode ser encontrado, no entanto, na ideia de uma vontade de todos 
unificada a priori (a ser unificada necessariamente), a qual é aqui sem mais pressuposta, como condição indispensável (conditio sine qua non); pois não se pode por vontade unilateral impor a outros uma obrigação que eles não teriam por si de outra forma. - Mas o estado de uma vontade efetivamente unificada de maneira universal no intuito da legislação é o estado civil. Portanto, algo externo pode ser adquirido originariamente tão somente em conformidade com a ideia de um estado civil, i. é, em vista dele e de sua efetivação, mas antes de sua efetividade (pois, do contrário, a aquisição seria derivada), portanto apenas provisoriamente. (Kant I. , 2014, p. $72 / 73)$

Kant entende o estado civil como um estado dos indivíduos do povo em relação uns com os outros, composto por uma multidão de homens, os quais, encontrando-se sob influência recíproca entre si, necessitam de um estado jurídico sob uma vontade que os una, uma constituição, a fim de alcançarem o que é de direito (Kant I. , 2014, p. 125).

A concepção do estado civil em Kant é fundamental não apenas como forma de legitimação do direito de propriedade. Trata-se, em verdade, de uma decorrência do próprio sistema de direitos defendido pelo referido autor. De fato, o estado civil deve ser compreendido, inclusive, como forma de efetivação de uma das formulações do imperativo categórico, em seu aspecto prático consistente na seguinte lei: "age de tal maneira que uses a humanidade, tanto na tua pessoa como na pessoa de qualquer outro, sempre simultaneamente como fim e nunca simplesmente como meio" (Kant I. , 2011, p. 73)

Desse postulado decorre que o ser humano tem direito à autodeterminação e não deve se submeter à dependência de quem quer que seja. Sendo um fim, por si só, não há como se estabelecer uma relação de dependência entre as pessoas. Deve-se reconhecer, todavia, que a vontade unilateral pode não ser suficiente para a verificação prática de tal postulado.

De fato, para se implementar tal postulado no mundo sensível, notadamente no âmbito das relações sociais, políticas e econômicas, faz-se necessária a efetivação do estado civil, a partir da atividade legisladora produzida pela vontade unificada. Essa necessidade decorre, pois, do fato de que "antes de ser constituído um estado legal público, homens, povos e Estado isolados jamais podem estar seguros contra a violência 
de uns contra os outros, e, na verdade, com base no direito próprio de cada um fazer o que lhe parece justo e bom e não depender nisso da opinião do outro". (Kant I. , 2014, p. 126)

A efetivação da formulação da não dependência entre os seres humanos, e a respectiva necessidade de se compreender o homem como um fim em si mesmo, tem como pressuposto, portanto, não só a existência de um estado civil, como se demonstrou acima, mas, igualmente, a capacidade de, no âmbito desse estado civil, se promover a unificação da vontade "onilateral".

Ousamos dizer mais - e nisso reside uma das conclusões deste tópico para os fins ora pretendidos: a medida da legitimidade do estado civil é a exata medida de sua capacidade de instituir a unificação da vontade "onilateral".

Ora, não se desconsidera que a fundamentação teórica de Kant é, por essência, apriorística, e, portanto, prescinde de qualquer circunstância empírica ou circunstancial para estabelecer a sua validade racional. No entanto, entendemos absolutamente pertinente indagar se se pode considerar como implementado o estado civil (capaz, assim, de fazer cessar a violência acima mencionada) na hipótese em que as instituições públicas se mostram absolutamente inaptas a atribuir, erga omnes, o caráter de cidadania universal necessário para o exercício da liberdade manifestada no consentimento que se consubstancia na unificação da vontade no âmbito do poder legislador.

Quer nos parecer que a resposta, nesse caso, seria negativa. A propósito do tema, esclarece Kant:

Os membros de tal sociedade (societas civilis), i. é, de um Estado, reunidos para a legislação, chamam-se cidadãos (cives), e seus atributos jurídicos, inseparáveis de sua natureza (como cidadãos), são a liberdade legal, de não obedecer a nenhuma lei a que não tenham dado o seu consentimento - a igualdade civil, de não reconhecer com relação a si mesmo nenhum superior no povo, a não ser um em relação ao qual ele tenha a mesma faculdade moral de obrigar juridicamente que $o$ outro tem de obriga-lo; terceiro, o atributo da independência civil, de não ficar devendo sua existência e sustento ao arbítrio de um outro no povo, mas a seus próprios direitos e forças, como membro da república, por conseguinte a personalidade 
civil, de não poder ser representado por nenhum outro em assuntos jurídicos. (Kant I. , 2014, p. 128/129)

Os aspectos elementares, portanto, do estado civil seriam a cidadania, a liberdade, a igualdade civil e a independência civil. Nesse sentido, a legitimidade do estado civil pressupõe a presença de tais elementos, sob pena de se ter infirmada a autonomia da vontade racional como força motriz da autodeterminação humana.

Ora, se tal como explicitado anteriormente, o direito de propriedade na teoria de Kant tem por pressuposto a existência de um estado civil que torne efetiva a vontade unificada "onilateral", e este, por sua vez, depende dos seus fundamentos acima explicitados, é de se concluir que o direito de propriedade, por si, exige a presença destes elementos que qualificam a manifestação de vontade racional e o consentimento. Consequentemente, tão próximos estaremos do estado natural, com seus violentos consectários, quanto ausentes os elementos essenciais do estado civil.

Reforçando tal conclusão, é de se notar que Kant admite que restrições ao direito de propriedade seriam legítimas caso fossem adotadas para a preservação e efetivação de um estado civil. Àquela época, portanto, já não se mostrava adepto de concepções absolutistas do direito de propriedade, que o tornasse independente de qualquer circunstância externa.

De fato, Kant admite que o direito de propriedade seja restringindo para garantir o direito de subsistência dos menos favorecidos, de modo a se preservar, minimamente, a existência de um estado civil, in verbis:

O comandante supremo tem indiretamente, i. é, como responsável pelos deveres do povo, o direito de onerar o povo com tributos para a sua (do povo) própria preservação, como são os asilos, os orfanatos e as igrejas, chamados também de instituições de caridade ou pias.

Pois a vontade geral do povo se reuniu numa sociedade que se deve preservar constantemente, tendo-se submetido ao poder público interno no propósito de preservar os membros da sociedade que não conseguem por si sós. O governo tem, portanto, por razões públicas, o direito de obrigar os abastados a fornecer os meios para a preservação daqueles que não o são, mesmo em termos das necessidades naturais mais elementares; 
porque sua existência é ao mesmo tempo um ato de submissão à proteção e ao cuidado da coisa pública, necessário para sua existência, com o qual se comprometeram, no que o Estado funda então seu direito de obrigar os abastados a contribuir o seu para a preservação de seus concidadãos. (Kant I. , 2014, p. $142 / 143)$

O dever de prover um mínimo de subsistência aos pobres, portanto, está intimamente ligado à necessidade de preservação do estado civil, ainda que de tal aspecto decorra a necessidade de limitar o direito de propriedade por meio da imposição da taxação.

A referida tese é defendida por Ernest J. Weinrib, para quem:

(...) property and the public duty to support the poor are conected through a single sequenced argument that extends the reach of universal principle of Right while preserving consistency with the ideas of rightful honor, innate equality and non-dependence that principle implies. For Kant, taxation is not theft, and neither is property. On the contrary, the two are necessary for a civil condition. On Kant's view as I have reconstructed it, the public duty to support the poor is latent within private property as a rightful institution. (Weinrib, 2003, p. 828)

Raciocínio análogo deve ser aplicado aos fatores que impedem a plena realização da liberdade humana no âmbito do estado civil. Mais do que, simplesmente, prover a subsistência, o estado civil deve ser capaz, para sua própria preservação, de promover a liberdade, como direito inato do ser humano, com todas as consequências que desse direito decorrem, como, v.g., a igualdade, cidadania e a independência civil.

No que concerne ao direito de propriedade, portanto, não se consegue configurálo de forma peremptória no âmbito de um estado no qual não se identifica uma congregação de vontades ou, mais precisamente, de um consentimento universal em relação à autorização que é conferida ao titular do domínio de impor aos demais um dever de abstenção, em relação aos seus direitos, com proprietário, de modo a ser possível o alcance dos seus próprios fins. Esse estado, como visto acima, aproxima-se da ideia de estado natural e caracteriza-se pelos conflitos e tensões decorrentes da ausência de 
consentimento mútuo (universal) em relação ao conjunto de regras que dão efetividade ao direito de propriedade.

Em conclusão, o estado civil, como consectário prático da necessidade de se superar o estado natural, deve guardar íntima relação com os fundamentos das ideias de imperativo categórico e da lei universal, assim se caracterizando por uma realização pública, por intermédio de instituições que garantam a plena autodeterminação da vontade humana, promovendo a liberdade, igualdade e independência. A medida de efetivação dos referidos pressupostos é a medida da legitimação do direito de propriedade como manifestação da vontade livre "onilateral" unificada.

\subsection{A perspectiva hegeliana sobre direito de propriedade}

\subsubsection{O legado crítico de Hegel ao liberalismo}

Hegel é frequentemente considerado por seu legado crítico às concepções liberais clássicas. As críticas de Hegel são, de fato, pertinentes. Alguns autores, todavia, como John Rawls, enxergam algumas compatibilidades entre as formulações de Hegel e o liberalismo clássico (Rawls, 2003, p. 365).

Uma das importantes críticas de Hegel ao liberalismo se refere ao fato de que os liberais não teriam formulado um objetivo universal e coletivo para a sociedade civil, cujos propósitos, segundo essa concepção, se prestariam apenas ao alcance dos interesses privados dos membros individualmente considerados. Não haveria, no liberalismo clássico, portanto, uma unidade de objetivos sociais, mas, tão somente, interesses atomizados.

Nada obstante, conforme se demonstrou acima, a teoria kantiana de principiologia advinda exclusivamente de uma razão pura parte do pressuposto de que o princípio universal seria (e apenas ele teria essa característica) compartilhado coletivamente, exatamente em razão de sua dissociação a questões empíricas e inclinações particulares.

Nesse sentido, pode-se afirmar que para o liberalismo kantiano existe, de fato, um objetivo coletivamente compartilhado, que residiria propriamente na necessidade de se resguardar os direitos constitucionais básicos, como decorrência do direito natural da liberdade humana. 
O liberalismo tradicional, portanto, tem como prioridade a garantia das liberdades básicas, como, v.g., liberdade de pensamento, liberdade de escolha, liberdade relacionada à escravidão e à servidão.

Outra crítica fundamental de Hegel reside no fato de que o liberalismo tenderia a não reconhecer as raízes sociais inerentes a um determinado arranjo político e institucional. Para Hegel, o liberalismo não admitiria a inserção das pessoas em uma determinada posição na sociedade como um fato relevante a ser considerado.

De fato, o reconhecimento do outro, nos termos em que serão expostos abaixo, trata-se de uma das principais contribuições de Hegel, notadamente se cotejado com a concepção individualista do legislador universal de Kant, que formula suas proposições a partir de sua razão pura prática, alheio a todo e qualquer fato empírico.

Autores liberais mais recentes, compreendendo a impossibilidade de se formular uma teoria metafísica totalmente dissociada de contextos sociais, objetivam desenvolver formulações que compatibilizem os ideais liberais com essa compreensão de pertencimento a um determinado contexto social, político e econômico.

Nessa linha, portanto, é que surgem as proposições de John Rawls e sua tentativa de estabelecimento de direitos fundamentais a partir de uma ideia de "posição original", que seria alcançada por meio do denominado "véu da ignorância", cujo objetivo seria, em apertadíssima síntese, alcançar um determinado consenso em relação a garantias e direitos específicos que deveriam ser observados independentemente de qualquer posição no âmbito de uma sociedade (Rawls, 2001, p. 15)

\subsubsection{A concepção de direito de propriedade de Hegel}

A teoria de direito de propriedade de Hegel pode ser enquadrada, a partir da classificação utilizada por Waldron, como um argumento baseado em um direito geral à propriedade (general right-based theory).

Uma teoria de propriedade privada baseada em direito, segundo Waldron, seria aquela que considera o interesse individual como suficientemente importante para, por si só, justificar a submissão dos demais (principalmente o governo) a deveres relacionados à criação, garantia, manutenção ou respeito à instituição da propriedade privada. (Waldron, 2002, p. 115) Nesse contexto, uma teoria baseada em direitos especiais (special rights-based theory) está relacionada à importância de um interesse, não em razão do interesse por si só, mas de algum evento contingente ou de um determinado conjunto de 
circunstâncias. (Waldron, 2002, p. 116) Por outro lado, uma teoria baseada em direitos gerais (general rights-based theory) não considera fatos ou eventos contingentes para dar a devida importância a um determinado interesse. A importância que se atribui a ele depende das próprias características do interesse por si só. (Waldron, 2002, p. 116)

Para Hegel, portanto, o direito à propriedade não decorre da ocorrência de um determinado evento ou da presença de determinadas circunstâncias. Se para Locke, por exemplo, há a necessidade de se promover uma "mistura" entre o trabalho de determinada pessoa e um objeto para que surgisse o direito à propriedade (special right-based theory), para Hegel, qualquer evento exterior aos próprios fundamentos do interesse, em si, não são relevantes para a legitimação de um direito de propriedade.

Hegel, assim, para fundamentar a sua ideia de direito de propriedade, se afasta de qualquer argumento relacionado a direitos individuais como decorrência de contratossociais e, principalmente, de qualquer argumento que tenha fundamentos utilitaristas, ou seja, que tenham por objeto de legitimação o bem-estar social ou a maior utilidade social agregada, pois, segundo Hegel, "no direito formal não se considera o interesse particular (o que me é útil ou agradável) nem o motivo particular da determinação do meu querer, nem a minha intenção nem o meu conhecimento de causa". (Hegel, Princípios da Filofia do Direito, 2009, p. 41)

O principal elemento do direito de propriedade em Hegel é a liberdade. Assim como as demais libertários, Hegel tem na liberdade o ponto fundamental de legitimação do direito de propriedade. Há, no entanto, diferenças fundamentais entre as teorias de Locke e Hegel no que concerne à legitimação do direito de propriedade no pilar da liberdade.

De fato, tem se tornado comum a efetivação da distinção entre Locke e Hegel, em relação às concepções de liberdade, por meio da ideia de liberdade negativa (Locke) e liberdade positiva (Hegel). A primeira refere-se a ela como uma abstenção de interferência ou constrangimentos, principalmente por parte do Estado, e especialmente em relação a direitos fundamentados na lei natural. Hegel, por outro lado, trata a liberdade como uma exteriorização da personalidade de modo a permitir a experiência de sua autorrealização. (S. Alexander \& M. Peñalver, 2012, p. 58)

Para Hegel a ideia de personalidade está intrinsecamente vinculada ao que ele denomina de consciência de si. O referido conceito é essencial na teoria de Hegel e vem explicitado em sua obra Fenomenologia do Espírito, mais especificamente ao tratar da dialética entre o Senhor e o Escravo. Em linhas muito genéricas - o que, por si só, 
constitui uma tarefa ousada e simplificadora em demasiado, haja vista a complexidade da obra de Hegel - a obtenção da consciência de si pressupõe um procedimento que envolve a exteriorização da consciência, em um primeiro estágio; a reflexão entre consciências exteriorizadas (aqui se dá o conflito entre o senhor e o escravo), seguida do reconhecimento da consciência do outro; e, por fim, culminando com uma abstração superior e mais pura da consciência, que, neste estágio, é denominada de consciência de si.

Em suas próprias palavras, Hegel esclarece:

A consciência-de-si é em si e para si quando e porque é em si e para si para uma Outra; quer dizer, só é como algo reconhecido. $\mathrm{O}$ conceito dessa sua unidade em sua duplicação, [ou] da infinitude que se realiza na consciência-de-si, é um entrelaçamento multilateral e polissêmico. Assim seus momentos devem, de uma parte, ser mantidos rigorosamente separados, e de outra parte, nessa diferença, devem ser tomados ao mesmo tempo como não-diferentes, ou seja, devem ser sempre tomados e reconhecidos em sua significação oposta. (Hegel, p. 126)

Mais adiante, Hegel especifica as etapas de constituição da consciência-de-si:

Somente nesses três momentos vem a completar-se o conceito de consciência-de-si: a) o Eu puro indiferenciado é seu primeiro objeto imediato; b) Esta imediatidade é porém, ela mesma, absoluta mediação, é apenas como supressão do objeto independente, ou é desejo. A satisfação do desejo é verdadeiramente a reflexão da consciência-de-si em si mesma ou a certeza tornada verdade; c) mas a verdade dessa certeza é, na realidade, uma dupla reflexão, a duplicação da consciênciade-si. (Hegel, p. 125)

A partir do referido procedimento é que é possível, segundo Hegel, a obtenção da ideia de personalidade e, ato contínuo, da liberdade efetiva. De fato, a partir do alcance da ideia de personalidade, relacionada ao livre arbítrio, que decorre da consciência de si, é que determinada pessoa tem a liberdade de exteriorizar a sua própria personalidade por 
meio de escolhas livres. Nessa linha, esclarecem ALEXANDER \& PEÑALVER que: “ $a$ person is a subject who self-consciously realizes freedom by realizing her needs and wants as chosen rather than given" (S. Alexander \& M. Peñalver, 2012, p. 59)

A personalidade, portanto, é um conceito essencial na teoria de propriedade de Hegel e é pressuposto do livre arbítrio e da liberdade, que é o fim último de sua ideia de propriedade e do próprio sistema de direitos. A propósito, assevera Hegel: "É a personalidade que principalmente contém a capacidade do direito e constitui o fundamento (ele mesmo abstrato) do direito abstrato, por conseguinte formal. $\mathrm{O}$ imperativo do direito é portanto: sê uma pessoa e respeito os outros como pessoas". (Hegel, 2009, p. 40)

O alcance da personalidade, por si só, a partir da consciência-de-si, porém, não é suficiente para Hegel. O livre arbítrio e as pessoas, como detentoras de um livre arbítrio, devem resolver a sua indeterminação e se colocarem no mundo exterior de modo a existir como ideia. Nesse sentido, explicita Hegel:

Deve a pessoa dar-se um domínio exterior para a sua liberdade a fim de existir como ideia. Porque nesta primeira determinação, ainda completamente abstrata, a pessoa é a vontade infinita em si e para si, tal coisa distinta dela, que pode constituir o domínio da sua liberdade, determina-se como o que é imediatamente diferente e separável. (Hegel, 2009, p. 44)

A pessoa deve exteriorizar o seu livre arbítrio e a sua personalidade naquilo que é externo, tornando como seu o contido no mundo exterior. A coisa, por outro lado, não tem um fim em si mesma. Disso resulta, portanto, o direito absoluto do homem de apropriação das coisas.

A propósito do tema, esclarece Waldron:

Hegel's thesis is that by appropriating, owning, and controlling objects, a person can establish his will as an objective feature of the world and transcend the stage in which it is simply an aspect of his inner and subjective life. (Waldron, 2002, p. 336)

Outro ponto importante na teoria de direito de propriedade de Hegel, segundo John Rawls, reside no fato de que as pessoas, como proprietários, podem fazer o que 
quiserem com a sua propriedade, desde que, evidentemente, o uso seja consistente com os direitos das demais pessoas (Rawls, 2003, p. 342). Esse ponto, particularmente, é fundamental para as pretensões ora objetivadas. De fato, tal assertiva deve ser compreendida no âmbito do conceito de liberdade e de livre arbítrio de Hegel. Ora, como visto acima, tais concepções estão intrinsecamente relacionadas com a ideia de consciência de si, como um pressuposto para o alcance de ambas e, ao final, da própria ideia de personalidade, que se constitui como o ponto crucial da teoria da propriedade de Hegel.

Nesse contexto, não se deve desconsiderar, para interpretar a assertiva de John Rawls, o procedimento, também acima sintetizado, necessário para o alcance da consciência de si. Fundamentalmente, e para o ponto que se objetiva defender, não se deve olvidar que a consciência de si é apenas alcançada a partir de um estágio reflexivo de reconhecimento com o outro.

O estágio de reconhecimento e reflexão para o alcance da consciência-de-si não deve, jamais, ser confundido como uma mera ideia de alterum non laedere. Deve-se reconhecer que Hegel, na dialética do Senhor e do Escravo (uma luta de vida e morte), transcende, e muito, essa ideia e faz pressupor que a consciência-de-si (pressuposto da liberdade plena) é dependente de um reconhecimento pelo outro. Ou, ainda, como acima explicitado "a consciência-de-si é em si e para si quando e porque é em si e para si para uma Outra; quer dizer, só é como algo reconhecido" (Hegel, p. 126)

A propriedade para Hegel, tal como mencionado anteriormente, não está relacionada a qualquer aspecto associado a satisfação de desejos e utilidades, sejam individuais ou coletivos. Nesse sentido, esclarece Hegel: "do ponto de vista da carência, e caso esta seja colocada em primeiro plano, ter uma propriedade aparece como um meio. Mas é outro ponto de vista que reside a verdadeira situação, o da liberdade que na propriedade tem a sua primeira existência, o seu fim essencial para si”. (Hegel, 2009, p. 47)

Insere-se como conceito fundamental, na teoria de propriedade de Hegel, a ideia da corporificação. Segundo Hegel, o sistema de propriedade é justificado, em sua verdadeira posição, como a mais apropriada corporificação da liberdade.

Nesse sentido, o corpo significa a primeira corporificação da liberdade. Trata-se da primeira forma pela qual se exterioriza a personalidade. A pessoa se torna objetiva, para ela mesma, por meio de seu corpo. É pela exteriorização pelo corpo é que cada pessoa é diferenciada das outras. Toda, pessoa, portanto, precisa ter seu próprio corpo, de modo 
que a inexistência de um corpo significa a própria morte. Da mesma forma, não ter a possibilidade de exteriorizar a sua própria personalidade por intermédio da propriedade privada significa uma semelhante violação de um direito da personalidade. Por mais que não seja uma violação tão severa quanto à privação de se possuir um corpo (homicídio), a violação a esse direito de exteriorizar a própria personalidade em uma determinada coisa constitui uma séria restrição do exercício da personalidade e, por consequência, da própria liberdade. (Rawls, 2003, p. 342/343)

Portanto, o respeito à pessoa é refletido no respeito à integridade de seu corpo, levando-se em consideração a proibição à agressão e ao aprisionamento. Da mesma forma, o respeito à personalidade é refletido no respeito à propriedade privada, como exteriorização e corporificação da personalidade humana.

As principais características, portanto, da teoria de propriedade em Hegel referem-se à ideia da propriedade como a representação da liberdade (Rawls, 2003, p. 343) e como a exteriorização de uma personalidade que deve ser respeitada, não somente no sentido negativo - como em Locke -, mas, principalmente, no sentido positivo, de reconhecimento do outro, corporificado em sua propriedade, como resultado de um processo de reflexão e reconhecimento de uma consciência-de-si. 


\section{O paradigma do Estado Social e direito de propriedade}

\subsection{Marxismo clássico e propriedade}

Alguns autores objetivam separar a produção acadêmico-científica de Marx de seus textos engajados politicamente com a causa do comunismo. Nada obstante, do ponto de vista epistemológico, essa separação entre perspectivas do sujeito em relação ao objeto é extremamente controversa. Por mais que as obras de Marx tenham propósitos muito bem especificados (e distintos entre si), não se defende, para os fins ora propostos, uma completa separação entre perspectivas particulares de Marx e sua produção científica.

Desde já, é importante destacar que não se insere entre os fins deste trabalho uma explanação mais aprofundada, seja da perspectiva político-ideológica do referido autor, seja de suas análises das relações econômicas (materiais) e seus reflexos sociais e políticos. Pretende-se, apenas, pinçar alguns elementos relativos às suas contribuições acerca de uma nova perspectiva sobre as relações decorrentes do direito de propriedade implantado pela burguesia, a partir dos ideais do liberalismo.

Nesse sentido, é oportuno compreender a obra do referido autor em um contexto de crise de um liberalismo com pretensões absolutas. A propósito do tema, faz-se oportuna a referência ao clássico introito do Manifesto do Partido Comunista, em que Marx e Engels afirmam que "um espectro ronda a Europa - espectro do comunismo" (Marx \& Engels, 2006, p. 21). Marx explica, em seguida, por meio de uma breve descrição histórica, formulada a partir do seu conhecido método dialético, que "o fantasma" do comunismo ronda a Europa exatamente em razão das contradições existentes no âmbito da sociedade burguesa, fundamentada nos princípios liberais. Se a burguesia teve a sua importância "revolucionária" para superar o sistema político, econômico e social do feudalismo, havia, então, se exaurido, por suas próprias deficiências, de modo a permitir o surgimento de uma nova força política, advinda do proletariado, que haveria de tomar o poder trilhando o caminho da dialética histórica por ele defendida (Marx \& Engels, 2006, pp. 23-45).

Marx sustentava que as relações econômicas materiais constituíam o substrato que moldaria as relações políticas e sociais e, consequentemente, as instituições. Nessa compreensão se insere a famosa metáfora do edifício e o seu conceito de infraestrutura e 
superestrutura, compreendendo-se a primeira como os fundamentos econômicos de uma sociedade da qual decorreria a segunda, composta pelos arranjos político-institucionais (Bottomore, 1988, p. 27).

O Direito, para Marx, também integraria o que se denomina de superestrutura para se manter a metáfora do edifício. Ou seja, o Direito deveria ser compreendido como um produto das relações econômicas de uma determinada sociedade. As instituições legais e jurídicas, portanto, consistiriam em instrumentos de reafirmação das relações de poder existentes. O Direito legislado, nesse contexto, consistiria em mais uma forma de alienação e, portanto, de manutenção do poder de uma classe dominante (Bottomore, 1988, p. 109).

Nesse sentido, Marx é crítico ferrenho da perspectiva kantiana de que seria possível a formulação de uma regra, ou de uma lei universal, obtida de forma absolutamente livre e racional, a partir da qual decorreriam as demais, em uma produção racional prática e autônoma. A esse respeito, assevera Marx:

Como o Estado é a forma na qual os indivíduos de uma classe dominante fazem valer seus interesses comuns e na qual se resume toda a sociedade civil de uma época, segue-se que todas as instituições comuns são mediadas pelo Estado e adquirem através dele uma forma política. Daí a ilusão de que a lei se baseia na vontade e, mais ainda, na vontade destacada de sua base real - na vontade livre. Da mesma forma, o direito é reduzido novamente à lei. (Marx \& Engels, 1993, p. 98)

Marx, portanto, explicitamente refuta a ideia kantiana de um direito e de uma razão fundamentados em reflexões metafísicas. A própria consciência racional dos homens está intimamente atrelada às relações materiais. De fato, a compreensão do homem na sociedade e a sua perspectiva de mundo são, igualmente, parte integrante da ideia de superestrutura, que, por sua vez, como visto acima, decorre diretamente da infraestrutura das relações econômicas.

Em alusão à ideia de liberdade hegeliana, Marx, igualmente, explicita que o desenvolvimento da filosofia metafísica e a obtenção da "autoconsciência" não libertaram ninguém de absolutamente nada, mormente da dominação de um "senhor" à qual o homem nunca foi submetido. Para o referido autor, "não é possível libertar os homens 
enquanto não estiverem em condições de obter alimentação e bebida, habitação e vestimenta, em qualidade e quantidade adequadas" (Marx \& Engels, 1993, p. 65).

No que concerne à propriedade privada, Marx também refuta a ideia de que seria possível o desenvolvimento de um sistema de direitos fundamentado em uma vontade geral dissociada das relações materiais. O direito de propriedade assim como os demais arranjos e instituições sociais estão vinculados à ideia de superestrutura, nos termos explicitados acima.

O referido autor chama a atenção ao fato de que o direito de propriedade está intrinsecamente vinculado a circunstâncias econômicas. O ius abutendi, v.g., de nada valerá se, por algum motivo, o proprietário não dispor de capital necessário para realizar os investimentos requeridos para o desenvolvimento da produção a ser cultivada em um determinado terreno. (Marx \& Engels, 1993, p. 100)

A rigor, a propriedade privada serviria como mais um instrumento de alienação, exatamente por reproduzir as correlações de forças políticas e econômicas dominantes. Por essa razão, portanto, o direito de propriedade deveria ser norteado para refletir as expectativas e propósitos da nova força política do proletariado. Para tanto, a propriedade privada, tal como a conhecemos, deveria ser, segundo a perspectiva ideológica de Marx e Engels, abolida. A propósito, esclarecem, no Manifesto do Partido Comunista:

Revoltai-vos por querermos suprimir a propriedade privada. Mas, em vossa sociedade atual, a propriedade privada está abolida para nove décimos de seus membros. Ela existe precisamente porque não existe para nove décimos de seus membros. Criticai-nos por querermos suprimir uma propriedade que pressupõe, como condição necessária, que a imensa maioria da sociedade seja desprovida de toda propriedade. (Marx \& Engels, 2006, p. 51)

O curso da história acabou por demonstrar a falibilidade das previsões do materialismo histórico proposto por Marx. De fato, as experiências sociais que foram estabelecidas sob a bandeira do comunismo perpassaram, em seu trajeto, por inúmeros desafios e obstáculos que não estavam previstos no programa inicialmente desenvolvido. Há, inclusive entre os marxistas, uma enorme polêmica a respeito da efetiva observância, no curso da História, das premissas originais da proposta marxista. (Aron, 1993, p. 186) 
O pensamento marxista, segundo Raymond Aron, passou por, ao menos, três grandes crises desde o seu surgimento. A primeira delas remete à discussão em relação à validade da previsão de que o antagonismo de classes se acentuaria ao ponto de resultar inexoravelmente no ocaso do capitalismo e na sua superação pela revolução comunista. A segunda refere-se às ditas experiências comunistas no curso da história e à respectiva identidade da realidade prática às diretrizes originais do programa. A terceira crise se refere ao embate entre a concepção socialista bolchevista, que propugna um Estado totalitário, e uma concepção mais abrandada, que, de um lado, defende a redução dos desequilíbrios e, de outro, admite elementos da democracia ocidental, incluindo pluripartidarismo, eleições livres e livre discussão de ideias. (Aron, 1993, p. 187)

Não se deve desconsiderar, no entanto, as críticas marxistas ao liberalismo metafísico e absolutista e às contradições dele decorrentes em sua realidade prática. De fato, Marx teve seu mérito ao expor que a liberdade - fundamento do liberalismo - não se alcança sem algumas condições materiais essenciais. Não se trata, portanto, de um conceito metafísico que se obtém por força de uma reflexão filosófica.

Nesse contexto, o direito de propriedade, igualmente, não pode ser compreendido sob uma pressuposta decorrência de um acordo de vontades obtido por uma adesão livre e racional de todos os integrantes de uma determinada sociedade. Assim sendo, a compreensão, na prática, ignora os desequilíbrios, o que resulta na prevalência das vontades mais livres que as demais. A decisão a respeito da alocação de recursos, nesse cenário, será inevitavelmente concentrada naqueles que, na prática, detêm melhores condições materiais de impor a sua própria vontade.

Se a propriedade está intimamente relacionada com a liberdade, como o reconhecem Kant e Hegel - cada um a partir de suas perspectivas - deve ela ser compreendida a partir do reconhecimento de que a liberdade sem a garantia de determinadas condições materiais não se mostra factível.

\subsection{Auguste Comte e a função social da propriedade}

Comte é considerado um dos co-fundadores da Sociologia, como ramo autônomo das ciências sociais. Apesar de crítico ao liberalismo clássico, não chegou a defender, como o fizeram Marx e Engels, uma ruptura revolucionária do regime anterior, para o fim de solucionar as mazelas então identificadas. Comte é considerado como o sociólogo da 
unidade humana e social, da unidade da história humana (Aron, 1993, p. 71). O referido autor, especificamente, é notabilizado por sua filosofia positivista. ${ }^{5}$

Enquanto Marx procurou enfatizar, em toda a sua obra, a relevância das relações econômicas para a estruturação das relações sociais e políticas, Comte fundamenta-se na ideia de que toda sociedade se mantém pelo acordo dos espíritos. A história da humanidade não é compreendida adequadamente pelos movimentos dialéticos propugnados por Marx - e tão bem retratados em sua clássica obra “O 18 de Brumário de Luís Bonaparte" (Marx, 2007), mas, sim, pelo entendimento de que é desenvolvida por um processo de aprendizado do positivismo pelo conjunto da humanidade.

Nessa linha de pensamento, Comte não considera que os antagonismos entre indústria capitalista e proletariado levariam a uma ruptura revolucionária. Ao contrário, compreendia que tais fatos seriam circunstanciais e episódicos, perfeitamente sanáveis por uma reorganização social conduzida por reformas. O aspecto da "organização" positivista, assim, constitui-se um elemento essencial na teoria de Auguste Comte.

O referido autor, no entanto, também se distingue do pensamento liberal clássico por criticar, assim como Marx, o pensamento metafísico - e, portanto, dissociado da realidade - como uma forma legítima de compreensão dos fenômenos sociais. De fato, Comte chegou a se aproximar consideravelmente das teorias socialistas, notadamente em razão de sua relação com Saint-Simon - de quem fora secretário durante anos, tendo rompido esse relacionamento exatamente em razão das discordâncias em relação à praxis socialista. (Giannoti, 1978, p. 11)

Situa-se, portanto, em uma posição intermediária entre o liberalismo e o socialismo. Como será exposto mais adiante, não defende o ius utendi et abutendi, assim como os romanos e os liberais clássicos os enxergavam. Por outro lado, também não defendia uma revolução que resultaria na socialização dos meios de produção. Em verdade, defendia reformas, orientadas pela filosofia moral positivista, de modo a, de um lado, reconhecer o direito de propriedade e, de outro, determinar a sua obediência a uma função social. (Aron, 1993, p. 82)

${ }^{5} \mathrm{O}$ referido autor considera que o caráter fundamental da filosofia positivista é, in verbis: "tomar todos os fenômenos como sujeitos a leis naturais invariáveis, cuja descoberta precisa e cuja redução ao menor número possível constituem o objetivo de todos os nossos esforços, considerando como absolutamente inacessível e vazia de sentido para nós a investigação das chamadas causas, sejam primeiras, sejam finais." (Comte, 1978, p. 43) 
De fato, Comte defende a relevância da propriedade privada, notadamente a partir da compreensão de sua inserção em um contexto de processo de aprendizado histórico da humanidade.

Ora, é inevitável que a propriedade (e o poder), a partir de um processo histórico, sejam concentrados nas mãos de um certo número de pessoas. A propriedade privada, no entanto, deve ser esvaziada de seu caráter arbitrário. Se o direito à propriedade privada é inevitável, apenas haverá de ser tolerada quando assumida, não como o direito de usar e abusar, mas como o exercício de uma função coletiva por aqueles menos favorecidos. (Aron, 1993, p. 82)

Comte, portanto, em princípio, não se insurge contra a concentração da propriedade privada na mão de um determinado grupo. A propósito, revela que "processos tirânicos" teriam muito menos eficácia na resolução de problemas sociais, do que a reprovação universal aplicada pela moral positiva a qualquer uso demasiado egoísta das riquezas. (Comte, 2000, p. 281)

Nesse sentido, o referido autor não enxerga maiores dificuldades na acumulação de capital. No entanto, essa concentração do capital resultará em uma responsabilidade relevante, conferida pela filosofia moral positivista, que orientará o uso da propriedade, não mais em sentido absolutista e egoísta, mas sim de modo a atender as reclamações mais graves do povo. (Comte, 2000, p. 281)

Em suas próprias palavras:

Em síntese, essa filosofia mostrará que as relações industriais, em vez de continuarem à mercê de um empirismo perigoso e de um antagonismo opressivo, devem ser sistematizadas segundo as leis morais da harmonia universal. (Comte, 2000, p. 282)

Tal como apontado por FRAZÃO, a teoria da função social da propriedade foi desenvolvida no âmbito de uma discussão mais ampla sobre solidariedade social. Nada obstante, atribui-se a Comte a primeira versão moderna do conceito (Frazão, 2006, p. 109).

Por fim, cabe destacar a relevante influência do positivismo na Europa e, especialmente, no Brasil. A rigor, a importância de Comte é percebida em diversas correntes de pensamento surgidas na Europa. Entre os autores influenciados por Comte, destaca-se, por sua proeminência, John Stuart Mill - um dos principais precursores no 
utilitarismo -, que chegou, inclusive, a prover Comte de recursos para sua subsistência em momentos de penúria, em retribuição à admiração por ele nutrida.

No Brasil, especificamente, floresceu-se não apenas o pensamento sociológicopositivista de Auguste Comte, mas também, a religião positivista por ele criada. A propósito, diga-se de passagem, até hoje subsiste a Igreja Positivista do Brasil, no Rio de Janeiro, apesar da queda de seu prestígio no decorrer do século XX. (Giannoti, 1978, p. 30)

O positivismo teve fundamental importância histórica no Brasil, notadamente por seu desenvolvimento por intermédio de Miguel Lemos e Benjamin Constant. De fato, credita-se ao positivismo de Comte o fato de ter-se alçado a uma das grandes correntes de pensamento que nortearam os ideais republicanos constantes de Constituição de 1891. A propósito, os dizeres da nossa bandeira, como se sabe, constituem uma expressão histórica da relevância do positivismo no pensamento político nacional.

\subsection{Durkheim, propriedade e a ideia de solidariedade social}

Uma das principais preocupações (se não a principal) de Durkheim reside nas relações entre indivíduos e coletividade. De fato, em sua obra "Da Divisão do Trabalho Social" (Durkheim, 1978), Durkheim objetiva apreender de que forma uma coleção de indivíduos é capaz de formar uma sociedade; e, no âmbito de determinada sociedade, como se compreender o que seria o consenso.

Para tal desiderato, Durkheim se utiliza dos conceitos de solidariedade mecânica e solidariedade orgânica.

A solidariedade mecânica está relacionada à ideia de semelhança. Ou seja, esse tipo de solidariedade seria formado quando há uma certa identidade, com pouca diferenciação, entre indivíduos, os quais compartilham dos mesmos sentimentos, valores e símbolos.

A solidariedade orgânica, por sua vez, se caracteriza exatamente por ser formada no âmbito de uma sociedade composta por indivíduos diferenciados entre si. A terminologia de Durkheim faz alusão a um determinado organismo, que é composto de vários órgãos, diferentes entre si, mas cada um fundamentalmente responsável por uma determinada função vital. No contexto sociológico, a formação de uma solidariedade orgânica se perfaz por intermédio da obtenção do consenso. 
As sociedades sem escrita (ou arcaicas), segundo a terminologia de Raymond Aron (Aron, 1993, p. 298), seriam formadas por uma organização tipicamente representativa de uma solidariedade mecânica, ou seja, na qual haveria uma identidade entre os indivíduos. No âmbito de um clã, v.g., os integrantes seriam intercambiáveis entre si.

No centro da dicotomia da solidariedade mecânica e da solidariedade orgânica, insere-se o conceito de consciência coletiva, conceito esse definido como sendo "o conjunto das crenças dos sentimentos comuns à média dos membros de uma sociedade" (Durkheim, 1978, p. 40).

Nesse sentido, no âmbito das sociedades caracterizadas pela solidariedade mecânica, a consciência coletiva, i.e., o conjunto de crenças e valores compartilhados, abrangeria a maior parte das consciências individuais. Assim, o espaço para a existência de valores e compreensões específicas dos indivíduos seria consideravelmente reduzido, em razão de uma quase identidade destas com aquelas comuns aos demais membros do grupo.

Diferentemente, no âmbito das sociedades formadas em um contexto de solidariedade orgânica, há um considerável espaço para que as pessoas tenham liberdade de crença, de valores e de interesses. A consciência coletiva, portanto, cede espaço para a liberdade individual.

Dessa linha de raciocínio, exsurge uma importante consequência para a teoria de Durkheim, consistente no fato de que a diferenciação individual dos integrantes de um determinado grupo social se daria a partir de uma tomada de consciência decorrente de um processo de desenvolvimento histórico. Ora, se nas sociedades ditas primitivas a identidade é a regra geral; a diferenciação entre os indivíduos se daria apenas a partir da evolução histórica das referidas sociedades, notadamente a partir dos processos comunicativos entre os componentes do grupo.

A consequência desse entendimento é que, para o referido autor, a individualidade nasce da sociedade; e não a sociedade seria uma consequência de um acordo de vontades manifestadas livremente por seus pretensos integrantes.

Trata-se, nesse sentido, de um importante contraponto de Durkheim em relação às concepções do liberalismo, no sentido de que a sociedade seria formada por uma espécie de um contrato social livremente acordado por seus integrantes. Ora, se a solidariedade mecânica precede a noção da individualidade, não haveria como se compreender o surgimento de uma sociedade a partir da compreensão do indivíduo. Da mesma forma, se 
a solidariedade mecânica é predecessora da solidariedade orgânica, não se pode explicar a ideia de individualismo e diferenciação social tendo como ponto de partida o próprio indivíduo.

Durkheim, nesse aspecto, portanto, se distancia das concepções contratualistas. De fato, a sociedade não está fundamentada em um contrato, assim como a divisão do trabalho não se compreende a partir da concordância individual das pessoas que compõem uma sociedade. Ao contrário, para que um determinado contrato tenha a sua validade jurídica e possa produzir os efeitos, já deve estar estabelecida uma estrutura social que sustente as consequências que deverão advir de um acordo de vontades formalizado por um contrato. Nesse sentido, a divisão do trabalho pela diferenciação é a condição primordial para que se possa instituir um contrato apto a produzir validamente os seus efeitos jurídicos e econômicos (Aron, 1993, p. 304).

A diferenciação, portanto, evidenciada na divisão do trabalho social, é fundamental para o alcance da individualidade e das liberdades individuais.

Nesse contexto se insere a concepção de propriedade privada para Durkheim e a sua posição diferenciada, seja em relação ao comunismo, seja em relação ao liberalismo. De fato, para o referido autor, a ideia de propriedade coletiva (e nesse contexto se insere a referência expressa ao comunismo) está relacionada à sua concepção de solidariedade mecânica. Assim, havendo uma identificação plena de valores e sentimentos, a organização do sistema proprietário não poderia se dar de outra forma se não sob arranjos de características coletivistas.

Por outro lado, diferenciando-se expressamente da concepção hegeliana de propriedade, Durkheim não entende que a propriedade deva ser considerada como uma extensão da pessoa sobre uma coisa. Sustenta, todavia, que a propriedade se torna individual na medida em que a sociedade se desenvolve no âmbito de um processo de diferenciação, i.e., "quando o indivíduo, se desligando da massa, se torne ele também um ser pessoal e distinto, não apenas enquanto organismo, mas enquanto elemento da vida social" (Durkheim E. , 2000)

Para Durkheim, as coisas integram a sociedade assim com as próprias pessoas, e nela desempenham um papel específico. Ou seja, também é necessário que as relações das coisas com o organismo social também sejam determinadas (Durkheim É. , 1978, p. 61) As coisas, então, assumem funções importante na sociedade, notadamente, no âmbito da ideia de solidariedade orgânica, e, consequentemente, na divisão do trabalho social. 
É necessário destacar que a concepção de direito real para Durkheim está intimamente relacionada à ideia de solidariedade negativa, que seria caracterizada pelo estabelecimento de direitos intrínsecos à propriedade (usar, gozar e dispor da coisa), de um lado, e, de outro, principalmente, por limitações recíprocas entre as pessoas, de modo a não prejudicar o interesse de terceiros.

Nada obstante, ainda que o direito real seja caracterizado, essencialmente, pela ideia de alterum non laedere, a de solidariedade negativa apenas é possível em um contexto social no qual se possam reconhecer determinadas condições relacionadas a concessões mútuas e respeito recíproco. Tais condições, todavia, pressupõem a existência uma solidariedade positiva. De fato, em suas próprias palavras, Durkheim esclarece que "a primeira condição para que um todo seja coerente é que as partes que o compõem não se choquem em movimentos discordantes. Mas esse acordo externo não faz a coesão, ao contrário, a supõe. A solidariedade negativa apenas é possível onde existe um outra, de natureza positiva, da qual é simultaneamente a resultante e a condição”. (Durkheim É. , 1978, p. 64)

Nessa linha, conclui Durkheim:

Os homens apenas precisam da paz na medida em que já estão unidos por algum elo de sociabilidade. Neste caso, os sentimentos que os inclinam uns para os outros moderam naturalmente as exaltações do egoísmo, e, por outro lado, a sociedade que os envolve, podendo viver apenas sob a condição de não ser a cada instante sacudida por conflitos, pesa com a força sobre eles para obrigá-los a fazer as concessões necessárias. (Durkheim É. , 1978, p. 64)

Identifica-se, portanto, uma preocupação de Durkheim em relação aos aspectos de integração social, moldada por uma determinada consciência coletiva, mas sem um esvaziamento do espaço necessário para florescer diferenciações e particularidades. Há uma compreensão da relevância de um individualismo e de uma diferenciação. $O$ individualismo defendido por Durkheim, todavia, difere-se do liberalismo clássico, ao estar contextualizado em uma teoria ética e sociológica profundamente fundamentada na ideia de solidariedade social. De fato, nas palavras de Raymond Aron, "nessa sociedade individualista, o problema mais importante é o de manter o mínimo de consciência 
coletiva, à falta da qual a solidariedade orgânica provocaria a desintegração social" (Aron, 1993, p. 307).

\subsection{A função social da propriedade}

\subsubsection{A função social como um subproduto da crise do liberalismo}

As teorias sociológicas brevemente expostas, como se procurou enfatizar, surgiram em um contexto de mudanças políticas e sociais importantes, em decorrência do desgaste do modelo liberal clássico. As pretensões libertárias da burguesia, estendidas ao seu extremo, resultaram em desequilíbrios sociais de relevante gravidade, caracterizados por exclusão de boa parte da população em relação a direitos políticos, liberdades individuais e ao acesso a bens materiais de primeira necessidade.

A tão propagada liberdade individual mostrou-se dissociada, na prática, de uma realidade opressora para determinadas classes sociais. Daí a insistência quase messiânica de Marx no sentido de reforçar a importância da análise da liberdade e igualdade de direitos a partir da perspectiva vivenciada nas relações materiais. De fato, o materialismo histórico, como visto acima, revela-se como uma crítica importante ao projeto liberal de se buscar a conceituação da liberdade e da igualdade a partir de modelos metafísicos. Ora, tal como ironicamente Marx alertara, em referência à metáfora de Hegel relativa ao Senhor e ao Escravo, a metafísica nunca aprisionou ninguém, razão pela qual contra ela não deveriam ser dirigidos esforços abolicionistas.

Evidentemente, conforme se objetivou demonstrar, as críticas às concepções de direito do liberalismo clássico foram refletidas em uma mudança significativa na forma de compreensão do direito de propriedade, que se constitui um dos pilares da concepção liberal. Em um contexto de mudança do paradigma do Estado Liberal não poderia o direito de propriedade passar incólume aos anseios sociais que a impuseram.

Ora, o sistema jurídico criado a partir do Código Napoleão e da Declaração Universal dos Direitos do Homem fundamentou-se na ideia metafísica de direito subjetivo, decorrente de uma concepção de liberdade (e igualdade) inata.

Como acima explicitado (item 3.2), a liberdade kantiana, v.g., fundamenta um direito subjetivo no imperativo categórico formulado pelo legislador universal. Dessa concepção metafísica de liberdade decorreria um direito de propriedade, também de 
caráter individualista. $\mathrm{O}$ direito de propriedade estabelecido com tais fundamentos foi refletido no já mencionado artigo 544 do Código Napoleão como sendo o direito de gozar e dispor das coisas da maneira mais absoluta.

O materialismo das novas teorias sociais se impôs ao liberalismo e demonstraram que, conforme alertou Léon Duguit, em 1912, a referida concepção puramente individualista de direito seria tão artificial quanto à metafísica de direito subjetivo. Objetivando demonstrar a insustentabilidade dessa compreensão metafísica de direito individual, o referido autor esclareceu que essa ideia do homem natural, isolado, independente, em sua qualidade de homem de direitos anteriores à sociedade, e trazendo tais direitos para dentro de uma sociedade, é uma ideia absolutamente estranha à realidade. (Duguit, 1912, p. 18)

Diante dessa constatação, haveria de ser desenvolvido um sistema de direitos que contemplasse a realidade social que se impunha. O projeto liberal, consubstanciado nos códigos civis modernos, seria suplantado por um novo arranjo condizente com as percepções sociais e políticas desenvolvidas, entre outros, pelos autores anteriormente mencionados.

Nesse contexto, esclarece Léon Duguit que esse sistema deveria repousar em uma concepção exclusivamente realista, a qual eliminasse sucessivamente a concepção metafísica de direito subjetivo. Dessa forma, segundo o referido autor, se identificaria a noção de função social. (Duguit, 1912, p. 19)

No direito moderno, a propriedade não deveria ser compreendida como um direito intangível e absoluto de titularidade dos proprietários da riqueza. Segundo Duguit, a propriedade não seria um direito, mas, sim, uma função social. Assim, o detentor de uma determinada riqueza teria uma função social a cumprir, de modo que, na mesma medida em que essa missão fosse cumprida, seriam protegidos pelo Estado os atos do proprietário. Do mesmo modo, se o proprietário não cumprir, ou cumprir, mal a sua missão, como, v.g., não cultivar a terra de sua titularidade, a intervenção governamental será legítima para o fim de compeli-lo ao cumprimento da função social da propriedade, que consiste em assegurar o emprego das riquezas à conformação com a sua destinação. (Duguit, 1912, p. 21)

Verifica-se, portanto, que as novas concepções objetivam compreender o indivíduo, não mais como um sujeito absolutamente livre e autônomo, inserido em uma sociedade idealmente igualitária, mas como sujeito passível de responsabilidades 
decorrentes de uma função social específica, a ser empreendida em atendimento a interesses de uma coletividade, ainda que contrários às inclinações individuais.

Em suma, e sem desconsiderar a evolução no tempo da ideia de função social, as modificações advindas com a concepção do Estado Social resultaram em uma mitigação de um individualismo exacerbado. Houve, de fato, conforme se verifica nas teorias de Comte e Durkheim, tentativas de se coadunar o individualismo e os interesses coletivos, como propostas alternativas ao marxismo. Tais intentos, todavia, não deixam de representar uma necessária convivência entre individualismo e propósitos públicos, o que, de certo modo, mitiga as pretensões absolutistas do liberalismo clássico.

Conforme nos aponta Frazão, ao se mitigar a ideia de individualismo absolutista, as teorias que fundamentaram o Estado social acabam, nesse mesmo processo, por substituí-la pela funcionalização dos direitos subjetivos, com o objetivo de, dessa forma, assegurar o bem-estar comum. (Frazão, 2006, p. 116)

\subsubsection{A função social da propriedade e o papel do Estado}

A ideia de que o direito de propriedade estaria relacionado a um direito subjetivo a ser protegido pelo Estado, de forma a garantir a manutenção do seu status absoluto, é substituída pela compreensão de que a proteção estatal está intrinsecamente relacionada ao exercício de uma determinada função. Assim, para que seja possível o direito do proprietário encontrar guarida nas instituições do Estado, não é mais suficiente que o proprietário demonstre, tão somente, a legitimidade da aquisição de seu domínio. A proteção do Estado não mais se justifica pura e simplesmente por estar o proprietário exercendo a sua liberdade, perante a coisa, inatamente adquirida.

A própria legitimidade do direito de propriedade passa a ter como um de seus mais importantes pilares o exercício do domínio, não mais a partir das decisões e inclinações norteadas pela liberdade e pela autonomia da vontade, mas sim com fundamento no interesse alheio, consubstanciado em valores e propósitos identificados socialmente. A autonomia da vontade, quando confrontada com um valor social eventualmente incidente sobre a propriedade, cede espaço para o atendimento de um propósito de utilidade pública.

Nesse contexto, surge uma discussão relevante em relação ao papel do Estado na proteção da propriedade e na garantia da função social da propriedade. Ora, se, em tese, uma decisão lastreada puramente na autonomia da vontade poderá ser diversa de outra norteada por interesses sociais coletivos, o Estado, como detentor do monopólio do uso 
da força, deverá intervir para, a partir do exercício do poder de polícia, impor o interesse público, quando assim o arranjo jurídico-institucional o permitir.

A proteção ao direito de propriedade, portanto, por parte do Estado, conforme apontado por Leon Duguit nos termos acima alinhavados, está condicionada ao exercício dos poderes inerentes ao domínio em correspondência com os valores sociais almejados pela sociedade em relação à propriedade.

Tal concepção suscita um apontamento relevante em relação ao papel do Estado no que concerne ao direito de propriedade vis-à-vis a sua função social, que costuma ser objeto de confusões por parte da doutrina. De fato, tende-se a se promover uma associação entre a função social da propriedade e o direito-dever do Estado de impor as limitações administrativas.

A propósito do tema, como nos alerta Carlos Ari Sundfeld, "o princípio da função social não é o fundamento das clássicas limitações administrativas à propriedade (Poder de Polícia)”. (Sundfeld, 1987, p. 7)

Esclarece o referido autor que, a rigor, o Estado, independentemente da função social, tem o poder-dever de impor restrições a particulares, inclusive em relação ao direito de liberdade, com vistas a alcançar o atendimento de um determinado interesse público, em detrimento da vontade do particular. É falsa, portanto, a premissa no sentido de que apenas a função social fundamentaria as limitações administrativas impostas ao titular do domínio. A supremacia do interesse público, por diversos fundamentos - desde que constitucionalmente legitimados - pode justificar a intervenção no direito de propriedade.

A função social da propriedade, no entanto, pode, sem sombra de dúvidas, impor limitações ao direito de propriedade, para conformá-lo com a destinação que dela se almeja. A autonomia individual pode, efetivamente, estar sujeita ao poder do Estado para adequá-la ao interesse público, no que concerne ao exercício dos direitos em relação a uma determinada coisa. Nesse sentido assevera Luiz Edson Fachin:

A função social da propriedade corresponde às limitações fixadas no interesse público e tem por finalidade instituir um conceito dinâmico de propriedade em substituição ao conceito estático, representando uma projeção da reação anti-individualista. (Fachin, 1988, p. 19) 
Importante destacar que a atuação estatal não está direcionada, apenas, à imposição de limitações, ou seja, no sentido de coibir a realização de algo em contrariedade ao interesse público. A esse respeito, Carlos Ari Sundfeld rechaça a ideia de que o Poder de Polícia teria apenas um sentido negativo. (Sundfeld, 1987, p. 10)

O direito de construir um determinado edifício poderá, por exemplo, estar limitado a um determinado coeficiente de aproveitamento que vede a construção acima de 10 andares. Da mesma forma, a edificação poderá estar condicionada à obrigação de fazer, consistente na realização de obras de infraestrutura viária para mitigar os impactos causados no trânsito com a futura ocupação do empreendimento imobiliário.

Verifica-se, a partir do exemplo apresentado, que, nos termos utilizados pelo referido autor, "o que caracteriza a Polícia Administrativa, como entendida tradicionalmente, é a atividade de limitar e condicionar a liberdade e a propriedade, para adequá-las aos objetivos públicos” (Sundfeld, 1987, p. 10). A limitação, portanto, pode ser concretizada seja por uma proibição, seja por uma obrigação de fazer.

Há que se indagar, ainda, se a função social da propriedade se restringe, apenas, à imposição de limitações e condicionantes relacionadas à utilização da propriedade, ou se, além de tais aspectos, referido princípio poderia impor ao particular a obrigação de exercer um determinado direito em benefício do interesse público. Haveria, portanto, como se obrigar o proprietário de um imóvel a efetivamente exercitar o seu direito sobre a coisa com fundamento na função social?

É de se notar que se trata de dimensões distintas de interferência no direito de propriedade, por parte do poder público, com fundamento na função social. A primeira delas está relacionada à imposição de limitações e condicionantes para um determinado uso. Em tese, bastaria, nesse aspecto, que o particular se abstivesse de utilizar a propriedade para que deixassem de ter eficácia as limitações e condicionantes. Mais além, a imposição da obrigação de exercer um determinado direito decorrente do domínio exigiria uma atuação do particular, tão somente pelo fato de ser o titular da coisa.

Quer nos parecer que o direito brasileiro vem, sistematicamente, implementando hipóteses em que é legítimo, com o fundamento da função social, a imposição do efetivo exercício de um determinado direito decorrente do domínio. O que, sob a perspectiva do liberalismo, era considerado uma prerrogativa decorrente do domínio, passa, atualmente, a ser compreendido como um dever decorrente de um determinado interesse público.

Nesse contexto, o exemplo mais cristalino desse fenômeno, refere-se ao arcabouço normativo criado para coibir o domínio especulativo da propriedade imobiliária. A 
propósito, a Lei 8.629/93 é explícita ao condicionar o direito de propriedade imobiliária rural a uma efetiva destinação produtiva que atenda à sua função social. $\mathrm{O}$ artigo $5^{\circ}$ da norma em questão prevê que a propriedade que não atenda à sua função social é passível de desapropriação por interesse social. Já o artigo $9^{\circ}$ explicita que a função social é atendida quando se verificam, concomitantemente, os seguintes requisitos: (i) aproveitamento racional e adequado; (ii) utilização adequada dos recursos naturais disponíveis e preservação do meio ambiente; (iii) observância das disposições que regulam as relações de trabalho; (iv) exploração que favoreça o bem-estar dos proprietários e dos trabalhadores.

A lei em questão, portanto, atribui ao Estado a prerrogativa de promover a desapropriação de área que não atenda à sua função social. A contrario sensu, a norma impõe ao titular do domínio o dever de exercer os poderes inerentes à propriedade, segundo a destinação que se espera de um determinado imóvel rural, sob pena do próprio domínio.

Evidencia-se, assim, que a atuação estatal, para a finalidade de concretizar o princípio da função social, poderá ser revelada: (i) na imposição de limitações, de caráter negativo, consubstanciadas, por exemplo, em obrigações de não fazer; (ii) na fixação de condicionantes para o exercício de algum dos direitos decorrentes do domínio, incluindo prestações de caráter negativo ou positivo, como, v.g., a obrigação de construir viários para a realização de empreendimentos imobiliários; (iii) na determinação imposta ao particular no sentido de exercer algum direito decorrente do domínio; assim como previsto na Lei 8.629/93, acima mencionada.

Afora a importante missão de materializar a eficácia, em situações concretas, nos aspectos retro referidos, o Estado possui um papel relevantíssimo na especificação do conteúdo da função social.

De fato, objetivou-se, anteriormente, esboçar aspectos teóricos fundamentais com o propósito de nortear uma compreensão científica do que poderia constituir o conteúdo social e político da função social da propriedade, a partir da contextualização de seu surgimento no âmbito da crise do liberalismo e do desenvolvimento de teorias jurídicosociológicas que tinham por objetivo suplantar as percepções liberais clássicas.

Evidentemente, todavia, a compreensão teórica resultante de tais contribuições não se mostra suficiente para a concretização dos efeitos jurídicos práticos decorrentes do princípio da função social. 
Diante disso, o Estado tem um papel fundamental, em primeiro lugar, para a obtenção de um consenso, devidamente legitimado, a respeito do que seria o conteúdo mínimo da função social, para que seja possível, em segundo lugar, uma atuação do Estado no sentido da concretização do referido conteúdo.

A se considerar notadamente o modelo democrático do direito de propriedade, que se almeja delinear no presente trabalho, deve-se sopesar a relevância das instituições sociais e do Estado que viabilizam a concretização democrática de direitos.

De fato, como será problematizado adiante, uma mera referência à previsão constitucional da função social não se mostra suficiente para que sejam legitimadas todas e quaisquer intervenções no direito de propriedade, com um fundamento suscitado a partir do interesse público.

O direito de propriedade, conforme amplamente explicitado anteriormente, é lastreado em valores relevantes, sob a perspectiva - também legítima - individual. Autonomia, liberdade, igualdade, necessidade de exteriorização material de manifestações individuais, dentre outros, constituem princípios éticos, sociais e políticos caríssimos às sociedades. No âmbito do paradigma do Estado Democrático de Direito, portanto, ponderações e relativizações de tais princípios apenas alcançariam a necessária legitimação política, no âmbito de instituições e procedimentos também legitimados democraticamente.

Muito embora a tais aspectos seja dado o devido tratamento oportunamente, se faz imperioso, neste momento, reforçar o papel do Estado e de suas instituições na obtenção do conteúdo normativo da função social, de modo que seja viável a concretização - não autoritária - das intervenções à liberdade e à autonomia privada que também fundamentam o direito de propriedade.

4.4.3. O conteúdo da função social da propriedade e sua problematização

Léon Duguit insere-se entre os que, originalmente, buscaram alcançar a determinação de um conteúdo da função social da propriedade, em seu contexto moderno. Como visto acima, o referido autor defende que o emprego da riqueza apenas seria legítimo e, portanto, passível de ser garantido pelo Estado na exata medida em que fosse norteado para o atendimento de sua destinação social. 
Com vistas a alcançar uma mínima determinação do que seria a função da propriedade, Duguit procura relacioná-la ao desenvolvimento da ideia de interdependência social. Nesse contexto, apresenta duas proposições, com o intuito de caracterizar o conteúdo da função social: (i) o proprietário tem o dever e, por conseguinte, o poder de empregar a coisa na satisfação das necessidades individuais, no desenvolvimento de suas atividades físicas, intelectuais e morais; (ii) o proprietário tem o dever e, portanto, o poder de empregar a coisa na satisfação das necessidades comuns, das necessidades de uma coletividade. (Duguit, 1912, pp. 165-166)

Duguit, assim, não se posiciona contrariamente à existência da propriedade privada e de uma relativa autonomia no que concerne ao seu emprego. Ao contrário, é explícito ao defender a sua relevância para o alcance das necessidades individuais fundamentais - não só as condições materiais mínimas para subsistência do proprietário, mas também aquelas necessárias para o seu desenvolvimento físico, moral e intelectual. Em paralelo, é enfático na defesa do emprego concomitante da riqueza para o atendimento das necessidades coletivas. Aproxima-se, dessa forma, da teoria de Comte em relação à necessidade de se empregar as riquezas para o atendimento "das reclamações mais graves do povo", como dito acima (Comte, 2000, p. 281). A moralidade e a ordem positivistas norteariam o emprego da propriedade ao cumprimento de sua função social de atender a interesses metaindividuais.

Assim como sintetiza Victor Carvalho Pinto, três são as principais consequências da perspectiva de Duguit acerca da propriedade privada e sua função social: (i) é reconhecida a importância da propriedade privada; (ii) o direito de usar o bem decorre do dever de fazê-lo e (iii) o caráter fundamental da propriedade é a sua afetação a uma finalidade específica. (Pinto, 2014, pp. 154-155)

Durkheim, por sua vez, conforme explicitado anteriormente, dedica boa parte de sua obra para conciliar uma concepção de individualismo relacionada a uma espécie de diferenciação funcional do particular no âmbito da ideia de solidariedade orgânica. Os indivíduos, assim como a propriedade, devem ser orientados a partir de sua destinação específica. Ambos, pessoas e coisas, integram funcionalmente um organismo social, no qual cada um tem um papel a ser cumprido, com vistas ao atendimento do interesse coletivo.

Karl Renner, autor positivista bastante influenciado por Comte e Marx, ainda na primeira metade do século XX, promoveu relevantes esforços para alcançar uma densidade concreta em relação ao que deveria ser entendido como função da propriedade. 
$\mathrm{O}$ autor em questão chama atenção ao fato de que o arcabouço jurídico que regulamenta o direito de propriedade não percebeu mudanças normativas significativas entre 1750 e 1900. Ainda assim, todavia, o instituto da propriedade mudou consideravelmente, notadamente, a partir de transformações significativas verificadas nas funções exercidas pelos diversos objetos de domínio. Bastante influenciado pelas teorias marxistas, Renner atribui às mudanças nas relações de produção explicitadas por Marx o caráter de ratio essendi do fenômeno em apreço. (Renner, 2001, p. 88 e ss.)

Nessa linha, assevera o referido autor que, a partir do advento do modelo de produção capitalista, evidencia-se uma alta diferenciação do objeto de domínio; ou seja, toda parte do patrimônio - terra, commodity, dinheiro - tem um destino separado e assume a sua específica função. Dessa forma, v.g., nas mãos de um proprietário, a propriedade pode exercer uma função relacionada a um título de poder, de lucro, de perceber juros, de lucrar com um determinado empreendimento ou de perceber os frutos com aluguel. (Renner, 2001, pp. 193-194)

Nesse contexto, tornando-se cada vez mais complexas e diversificadas as funções relacionadas à propriedade, há uma perda de sua independência e autossuficiência. A propriedade passa a depender de uma série de arranjos institucionais para que possa cumprir integralmente com as suas funções. Dessa forma, a propriedade, cada vez mais complexa, funcionalmente diversificada e dependente de circunstâncias sociais, passa afetar um determinado grupo de pessoas, ou uma coletividade. (Renner, 2001, p. 196)

É de se destacar, portanto, que há uma inter-relação relevante entre o direito privado e o direito público. Ora, a propriedade é inoperante sem a legislação processual civil, o que, por sua vez, também é inócuo sem as normas que regulam a organização das cortes. Nesse sentido, todo o direito privado, segundo Renner, teria uma contrapartida em direito público. (Renner, 2001, p. 76)

Ocorre que, no âmbito de um sistema capitalista - e nesse aspecto o referido autor é explicitamente influenciado pela metáfora do edifício de Marx, acima mencionada -, os arranjos institucionais estariam norteados no sentido de garantir a eficácia dos valores próprios do capitalismo, notadamente no sentido de reforçar as garantias (e funções) da propriedade privada. De fato, em suas próprias palavras, esclarece o autor que, no capitalismo, "as instituições somente vêm à tona quando o desenvolvimento das leis aponta para além do sistema capitalista" (Renner, 2001, p. 77)

Diante de tais aspectos, e, de alguma forma, influenciado pelos prognósticos de Marx em relação às alterações nas relações econômicas e sociais, o referido autor alerta 
para uma transformação em relação ao conteúdo da propriedade que refletiria os novos arranjos sociais. Essas transformações - segundo a ideia de desenvolvimento tal como articulada pelo materialismo histórico - também produziriam consequências no próprio conteúdo da propriedade privada, de modo a adequar as suas funções às novas relações econômicas e sociais.

Mais recentemente, e a partir das formulações realizadas por Renner, seguindo tal linha de raciocínio, José Afonso da Silva esclarece o seguinte:

E toda vez que isso ocorreu houve transformação na estrutura interna do conceito de 'propriedade', surgindo nova concepção sobre ela, de tal sorte que, ao estabelecer expressamente que 'a propriedade atenderá a sua função social', mas especialmente quando o reputou princípio da ordem econômica (art. 170, II e III), a Constituição não estava simplesmente preordenando fundamentos às limitações, obrigações e ônus relativamente à propriedade privada, mas adotando um princípio de transformação da propriedade capitalista, sem socializá-la; um princípio que condiciona a propriedade como um todo, não apenas seu exercício, possibilitando ao legislador entender com os modos de aquisição em geral ou com certos tipos de propriedade, com seu uso, gozo e disposição. A função social - assinala Pedro Escribano Collado - 'introduziu, na esfera interna do direito de propriedade, um interesse que pode não coincidir com o do proprietário que, em todo caso, é estranho ao mesmo', constitui um princípio ordenador da propriedade privada e fundamento da atribuição desse direito, de seu reconhecimento e da sua garantia mesma, incidindo sobre seu próprio conteúdo. (Silva, 2012, p. 74)

Maria Sylvia Zanello Di Pietro, na mesma linha, também explorando a dialética entre interesses individuais e coletivos, assim explicita o que seria função social da propriedade:

Em relação à propriedade privada, o princípio da função social, inspirado na doutrina social da Igreja, representa uma reação contra a concepção individualista do direito de 
propriedade privada e corresponde às concepções ideológicas que veem na propriedade não apenas um direito individual, mas também uma função - a de servir de instrumento para a consecução do bem comum. (Pietro, 2004, p. 562)

Como visto acima, Luiz Edson Fachin também fundamenta a sua concepção de função social da propriedade na ideia de limitações à autonomia individual impostas em benefício do interesse público - como uma projeção da reação anti-individualista - com o fim de instituir um conceito dinâmico de propriedade (Fachin, 1988, p. 19)

Sem se discernir dos autores acima mencionados, Arruda Alvim, ao explanar acerca da função social da propriedade, também o faz a partir da contraposição entre interesse individual e coletivo, no sentido de explicitar que a autonomia individual cede espaço à consideração de interesses públicos no exercício dos direitos inerentes à propriedade:

E o direito de propriedade passou a ter que observar, além do interesse do proprietário, os interesses da sociedade. Vale dizer, tanto o contrato quanto o direito de propriedade passaram a ser legitimados também ou principalmente em face da sociedade, e deixaram de gravitar e servir, exclusivamente, em torno do indivíduo.

Quanto ao direito de propriedade, acabou-se por abandonar a noção de direito subjetivo incondicionado, para uma noção de direito subjetivo convivendo com deveres do proprietário. (Alvim, 2014, p. 28)

Fredie Didier, por sua vez, faz referência à função social da propriedade como sendo um princípio que, complementando o conteúdo da propriedade privada, impõe um conjunto de deveres que estariam relacionados ao atendimento, pelo titular do domínio, do interesse público incidente sobre determinada coisa:

E aqui surge a concepção da função social da propriedade - outro princípio constitucional que rege a atividade econômica - e que aparece como complemento do estatuto constitucional da propriedade privada, impondo a ela 
um conjunto de deveres, ao lado dos clássicos poderes antes mencionados.

Este princípio (cláusula geral que rege a atividade econômica) serve como forma de balizamento constitucional do direito fundamental propriedade, delimitando o seu conteúdo. Estabelece que a propriedade obriga ao proprietário. Trata-se de construção que transformou estruturalmente o direito de propriedade. Além de poder jurídico, a propriedade traz consigo o dever de exercer este direito de modo a atingir determinadas finalidades; deixava a propriedade, pois, de ser um direito absoluto, cuja utilização deveria atender unicamente aos interesses do proprietário, na forma da concepção liberal que então prevalecia. (Didier Júnior, 2008, p. 11)

Interessante notar que, mais adiante, Didier, ao explicitar o texto dos dispositivos normativos que preveem a função social da propriedade, reconhece o caráter "aberto" de seu conteúdo, para o fim de ser devidamente preenchido pelo Judiciário:

Os enunciados normativos citados são abertos. O conteúdo de todo princípio é ilimitado, como, aliás, devem ser, exatamente para permitir a "abertura" do sistema jurídico, com soluções mais consentâneas com as peculiaridades do caso concreto submetido à apreciação do Poder Judiciário. (Didier Júnior, 2008, p. 12)

Marina Mariani de Macedo Rabahie, por sua vez, também desenvolvendo a sua percepção sobre a função social da propriedade a partir da dicotomia interesse público e privado, reforça a ideia de "poder-dever" do titular do domínio, como instrumento para o alcance de objetivos individuais e interesses de toda a coletividade:

\section{Quando a Constituição ainda que de maneira} programática, incluiu, dentre os seus comandos, o da função social da propriedade, alterou substancialmente a situação jurídica comum daquele que é proprietário. Isto é, o 
proprietário, entendido somente como um fiel cumpridor de interesses próprios passa a atuar, tal qual o Estado (ainda que este possua prerrogativas que lhe são exclusivas e próprias, o que o diferencia do particular) como um gestor de negócios da coletividade, um cumpridor de funções. Notamos, então, que ao menos desta específica função pública o particular é detentor. Além de usar, gozar e dispor do objeto de sua propriedade de modo a alcançar interesses próprios, deverá fazê-lo de maneira qualificada, para que atinja também os interesses de toda a coletividade, da qual faz parte.

Nesta altura de nossa exposição é preciso refletir sobre importantíssimo ponto: o entendimento segundo o qual o proprietário particular exerce funções que são quase públicas, perseguindo, portanto, utilidades sociais, não deve ser suficiente para que se chegue à conclusão de que ele deixa de ser titular de um direito subjetivo. Aliás, nem poderia ser assim, pois o nosso sistema de normas superiores outorgou-lhe direito de propriedade que é assegurado, salvo os casos previstos. Disto resulta que o particular reúne um poder (que viabiliza o exercício de seu direito subjetivo de propriedade, garantido constitucionalmente) ao qual se conjuga um dever-poder, que se exterioriza quando do exercício deste mesmo direito com vistas ao atingimento de finalidades sociais. A procura desses interesses sociais demonstra a existência de um poder instrumentalizador de um dever maior e fundamental, dirigido a finalidades públicas e do qual não se pode dispor - o dever de satisfazer as necessidades que a vida comunitária acarreta. (Rabahie, 1991, pp. 227-228)

Bastante significativa, igualmente, é a assertiva, da referida autora, no sentido de caracterizar a função social da propriedade como um instrumento para a busca da justiça social e do desenvolvimento nacional, in verbis:

Não podemos nos esquecer de que a função social da propriedade é instrumento que deve ser utilizado para o alcance 
da justiça social e também do desenvolvimento nacional.

(Rabahie, 1991, p. 230)

A digressão em relação às diversas percepções de doutrinadores pátrios acerca da função social da propriedade tem por objetivo demonstrar que as tentativas de se delimitar o conteúdo de tal princípio gira, basicamente, em torno de alguns elementos fundamentais.

De todo o exposto, parece claro que podemos extrair cinco conclusões mais comumente aceitas entre as perspectivas a respeito da função social da propriedade.

A primeira delas (e talvez a mais relevante) se refere ao fato de que a função social da propriedade tem sua origem na crise do liberalismo, tal como acima apontado - e por tal razão, não se mostram necessárias maiores digressões. Nesse sentido, o princípio em questão tem por objetivo a superação de uma percepção individualista (com pretensões absolutistas) derivadas das teorias filosóficas desenvolvidas no âmbito do liberalismo clássico. A mitigação da autonomia individual se faz com vistas a atender interesses coletivos que eventualmente possam incidir sobre o exercício dos direitos decorrentes da propriedade.

A ideia, portanto, de função social da propriedade, como subproduto da crise do liberalismo clássico, de natureza metafísica, objetiva estabelecer a vinculação do direito a propósitos socialmente concebidos. É, de certa forma, um movimento no sentido de subjugar o direito à realidade materialista que se impunha. A autonomia da vontade, muito embora importante, não pode ser tida, no contexto material vivenciado, como o único critério de decisão na alocação de recursos escassos e de extrema relevância para a coletividade.

A segunda característica, e, em boa parte, decorrente da primeira, refere-se ao fato de que a função social da propriedade não tem por objetivo a extinção da propriedade privada, mas, sim, a sua conformação com o interesse público. De fato, em todas as explanações acima discorridas, há uma preocupação comum no sentido de se reforçar a importância da propriedade privada. O próprio Duguit, considerado um importante precursor no desenvolvimento do princípio, é enfático em seu distanciamento em relação ao objetivo de se extinguir ou socializar a propriedade privada. Karl Renner, da mesma forma, muito embora fortemente influenciado por Marx, inclusive na adoção do materialismo histórico como instrumento de apreensão da realidade da propriedade visà-vis as relações econômicas e sociais, é expresso ao reafirmar a relevância da 
propriedade privada e da relevância da autonomia do indivíduo. O mesmo se diga em relação a Durkheim. Comte, por sua vez, se coloca ainda mais distante, ao não demonstrar nenhuma preocupação em relação à concentração da riqueza, desde que seu uso seja norteado no sentido de cumprir uma determinada destinação específica e que sejam atendidos os "mais graves" interesses coletivos.

De tal característica exsurge a constatação de que a ideia de função social da propriedade resulta da busca de uma alternativa ao prognóstico de Marx quanto à revolução proletária e a subsequente extinção da propriedade privada. O estabelecimento de garantias - como parte de um sistema de freios a um liberalismo opressor - parece ser o cerne do princípio da função social, como forma de se contemplar interesses relevantes de uma coletividade oprimida, sem, no entanto, a formulação revolucionária de alterações nos arranjos institucionais vigentes. Em tal aspecto talvez resida a perplexidade, acima mencionada, de Karl Renner, ao verificar sensíveis alterações no conteúdo da propriedade sem a respectiva percepção de mudanças normativas correspondentes.

A terceira característica refere-se ao fato de que a propriedade deverá atender a um determinado fim. Para atender a função social, deverá o proprietário (e não a propriedade, evidentemente) exercer os seus direitos típicos de titular do domínio em um determinado sentido que atenda a um interesse específico. Tal como nos esclarece Karl Renner, a propriedade sempre teve uma determinada finalidade, inclusive para o atendimento dos interesses individuais. Insta, portanto, entre os fins a serem possivelmente alcançados com uma determinada propriedade, identificar a que interesses eles serviriam e, em seguida, avaliar se eles poderiam ser legitimados juridicamente no âmbito do Estado Democrático de Direito.

No que concerne ao princípio em apreço, os fins serão aqueles norteados por um determinado interesse coletivo. $\mathrm{E}$, em tal aspecto, reside a quarta característica que se objetiva destacar. Ora, havendo fins (e, portanto, funções) individuais, incluindo capitalistas (como a função de acumulação de capital, mencionada por Karl Renner), norteará o princípio da função social que se conduza o proprietário para o fim de alcançar aqueles orientados pela coletividade.

Por fim, o quinto aspecto - talvez não mencionado por todos os autores, mas por uma relevante maioria - reside no fato de que a propriedade, com o advento da função social da propriedade, passa a ser caracterizada por um "poder-dever" do titular do domínio. Em outras palavras, o proprietário não deixa de ter suas prerrogativas inerentes ao domínio, no sentido de usar, gozar e dispor da coisa (não mais da maneira mais 
absoluta), mas tal poder é qualificado por um dever de se conduzir de modo a contemplar, no exercício de suas faculdades, interesses sociais de uma coletividade de não proprietários daquela coisa.

Tome-se, por exemplo, a ilustração da propriedade rural improdutiva, acima mencionada. O proprietário não tem, segundo a legislação brasileira, apenas o poder de cultivar a terra, tornando-a produtiva. Ele tem um dever - que decorre tão somente da qualidade de titular do direito de propriedade - de dar uma destinação produtiva mínima prevista em lei, sob pena de se sujeitar a um procedimento de desapropriação para a realização de reforma agrária. Ou seja, o próprio direito à propriedade da coisa coloca-se sob risco de extinção, caso não seja ele qualificado pelo emprego, por parte do proprietário, de suas prerrogativas a serviços de uma destinação econômico-social prevista em lei.

As características acima citadas, portanto, consubstanciam boa parte dos apontamentos realizados pela doutrina nacional acerca do que consistiria o conteúdo da função social da propriedade. As referidas concepções, longe de serem exaustivas, representam, de certo modo, como os juristas pátrios têm formulado diretrizes para a questão relativa ao conteúdo do princípio em referência, contribuindo sobremaneira com o avanço acerca da compreensão do complexo tema da propriedade privada.

Nada obstante, por mais zeloso e hercúleo que o jurista possa ser, uma tentativa de formação, em concreto, do conteúdo da função social da propriedade não poderá, em grande parte dos chamados "hard cases", ser alcançado a partir de um raciocínio lógicodedutivo que resulte em apenas uma única resposta correta e adequada com o sistema jurídico. Como se sabe, a possibilidade de existência de mais de uma resposta consentânea com as diretrizes gerais acima expostas, não raro, poderá abrir amplo espaço para florescimento de arbitrariedades e decisões autoritárias.

Pendem, portanto, importantes questionamentos, cuja resposta se faz necessária para que seja viável a eficácia, no caso concreto, do princípio da função social da propriedade.

Nesse sentido, poder-se-ia indagar: (i) com a superação de boa parte dos excessos do liberalismo clássico, o princípio da função social alcançou a plenitude de seu conteúdo normativo? Em outras palavras, o referido conteúdo é estático, e parou no tempo após o ocaso do absolutismo liberal, ou dinâmico (assim como pretende Fachin)?; (ii) se a ideia de função social está relacionada ao alcance de um determinado fim social, que fim seria esse? Como e de que forma tais fins seriam especificados? Os arranjos institucionais que 
fundamentam o exercício do direito de propriedade objetivam alcançar fins privados e fins sociais, apenas, ou há finalidades relacionadas a outros tipos de funções que poderiam legitimamente ser contemplados, como, por exemplo, funções ambientais, científicoacadêmicas, culturais, lúdicas, entre outros?; (iii) os fins em questão devem atender apenas aos interesses norteados pela dicotomia indivíduo/coletivo, ou há outros interesses que poderiam ser legitimados, como, v.g., interesses de minorias, interesses de futuras gerações? e (iv) se é verdadeiro que a função social impõe um dever ao titular do domínio, que dever especificamente seria esse? Como o proprietário - e devedor - poderia se desincumbir desse ônus, sendo certo que também lhe assiste o direito de cumprir com suas obrigações, e de não ser cobrado indevida e indefinidamente? Quem seriam os credores dessa obrigação? Ou seja, quem teria a prerrogativa de obter um provimento estatal no sentido de coagir o proprietário-devedor inadimplente a cumprir com suas obrigações?

De fato, do detido exame das diretrizes que se especificou acima, não se deduzem, facilmente, respostas convincentes às perguntas ora formuladas.

Nesse sentido, Eros Roberto Grau, no desenvolvimento de sua concepção de função social da propriedade, também faz alusão aos elementos principais acima destacados, como a relação do princípio com a limitação da propriedade em seu aspecto individualista; o caráter dicotômico do poder-dever relacionado ao exercício do direito de propriedade e a necessidade de observância de interesses coletivos. Reconhece, no entanto, o aspecto de indeterminação de seu conteúdo, o que exigira, segundo o referido autor, análise realizada a partir de uma multiplicidade de enfoques e critérios específicos. A propósito do tema, esclarece que:

A análise do instituto da propriedade, no Direito de nosso tempo, reclama uma multiplicidade de enfoques e critérios específicos. Ainda quando tomemos como objeto de pesquisa o princípio da função social, na tentativa de demarcação dos contornos de sua concepção e do seu raio de abrangência, ainda assim nos colocaremos, sempre, diante de um leque de aspectos a serem explorados, a reclamar a enunciação de um deles como primordial, em razão do qual se pretenda desenvolver a análise ensaiada. 
Isto porque, a função social da propriedade, na expressão de Salvatore Pugliatti, é poliédrica e pode ser dita verdadeiramente indeterminada - tanto são os aspectos sob os quais pode caracterizar-se uma função social, a qual terá não apenas vária relevância específica, mas poderá ter relevância em função da importância que o elemento social adquira em determinado momento aos olhos do legislador ordinário. (Grau, 1983, pp. 62-63)

A função social, conforme se verifica - assim como o reconhecem unanimemente os autores acima mencionados - está relacionada a uma determinada finalidade coletiva. É raro, no entanto, identificar-se uma problematização acerca do que seria essa finalidade coletiva, como deveria ela ser alcançada e com base em quais parâmetros.

A rigor, a propósito da definição do que seria efetivamente essa finalidade coletiva, temos alguns exemplos de determinação em casos específicos, como a legislação retro referida sobre a necessidade de se tornar produtiva a propriedade imobiliária rural. Afora isso, temos a explicitação de eventuais finalidades em casos submetidos ao Judiciário, conforme se explicitará mais adiante. Trata-se, no entanto, de soluções específicas para casos pontuais.

Carmen Lúcia, igualmente, reconhece o caráter de indeterminação da finalidade coletiva à qual deverá nortear a concretização do princípio da função social da propriedade. Nesse sentido, esclarece:

O que parece certo é que, em princípio e por princípio, a propriedade presta-se a, em sua essência, algo dado a cumprir função, daí ser ela instrumental, voltada a um fim.

A função, em qualquer caso, é dar a utilidade que apresente resultado sociopolítico e econômico nos termos juridicamente definidos como legítimos. Paralelamente, a utilidade própria da coisa (res) é obtida pelo atendimento daquilo que é posto como sendo a sua função.

Qual o fim e como se atender ao que se considera justo é a questão a ser resolvida pelos povos em seus diferentes sistemas jurídicos. É nestes que se normativizam as relações 
sociais para a concretização dos objetivos de Justiça da sociedade. (Rocha, 2004, p. 59)

Diante disso, é de se insistir, primeiramente, no reconhecimento de que há, efetivamente, uma indeterminação a respeito do conteúdo do princípio em questão. Uma vez reconhecido tal aspecto, volta-se à indagação a respeito de como se deve proceder para determiná-lo no caso concreto. Ou seja, qual procedimento deveria ser realizado para que se alcance legitimidade nas escolhas existentes acerca das possíveis finalidades? A quem seria atribuída essa importante tarefa? Quais balizas deveriam ser impostas para que o procedimento de escolha guarde coerência e certo grau de previsibilidade jurídica?

Como norte a orientar a busca pelas respostas pretendidas, dever-se-á, sempre, prestigiar o caminho indicado por critérios democráticos de legitimidade. Apenas por força da estrita observância de procedimentos legitimados democraticamente é que se evitarão autoritarismos ideológicos e casuísmos oportunistas.

Esse é o caminho que se pretende apresentar em conclusão ao presente trabalho.

Para tanto, todavia, é imprescindível a compreensão da propriedade, e de sua função social, como um produto de arranjos jurídicos e institucionais, sobre os quais recaem interesses, direitos e pretensões de diversas naturezas, e não apenas decorrentes da dicotomia indivíduo/coletivo.

De fato, além de finalidades relacionadas a aspectos individuais e coletivos, há interesses de natureza difusa, ou, ainda, de minorias, que também devem ser contemplados. São também finalidades importantes - e legitimadas - sob a perspectiva do Estado Democrático de Direito, que não se confundem, como genericamente se pretende fazer, com os interesses coletivos decorrentes de uma resposta que se almejou dar aos excessos do liberalismo clássico. É exatamente nesse contexto que surge a tentativa de se contemplar outras funcionalidades - como a ambiental, cultural, científica, etc. - no direito de propriedade.

Gustavo Tepedino, ao analisar a função social da propriedade e a sua relação com o dever de proteção do meio ambiente, chegou a conclusão semelhante em relação ao novo aspecto da funcionalização do direito de propriedade, que supera a dicotomia de interesses coletivo/privado. A esse propósito, transcrevo:

O estudo da função social da propriedade no âmbito do direito ambiental reflete a superação da dicotomia clássica entre o direito público e o direito privado. No passado, como se 
sabe, situava-se, de um lado, o direito privado, destinado a assegurar o império da vontade individual e dos direitos inatos dos indivíduos, excluindo-os da ingerência estatal. De outro, o direito público, como instrumental de organização do Estado de proteção do cidadão em face do arbítrio do Poder Público.

Atualmente, no entanto, percebe-se a necessidade de mobilização de todos os instrumentos jurídicos disponíveis, no âmbito do poder público e da iniciativa privada, para solução das questões ambientais, que adquirem relevância mundial, aproximando-se assim, na proteção da pessoa humana, mais e mais ameaçada pelos riscos ao ecossistema, o Direito Civil do direito administrativo e constitucional. (Tepedino, 2009, pp. 175-177)

Nesse sentido, portanto, se há variedade de interesses, direitos e pretensões a serem acolhidas no âmbito do exercício do direito de propriedade, a escolha entre as alternativas deverá ser realizada por meio de critérios que sejam legitimados pelo Estado Democrático de Direito.

Acresça-se, ainda, como visto, que a funcionalidade está relacionada a um fim a ser especificado pela sociedade. O fim, por sua vez, refere-se a uma determinada utilidade (distribuição equitativa de recursos, aumento de riqueza, bem-estar social, etc.).

Nesse contexto, deve-se levar em consideração, ainda, que os critérios puramente utilitaristas também se relevam extremamente controversos (apesar de importantes), conforme se analisará em seguida. Faz-se, portanto, igualmente, imprescindível compreender que decisões norteadas, exclusivamente, por critérios utilitaristas podem resultar em situações graves e dissociadas de valores socais relevantes.

Nesse sentido, há importantes críticas, adiante detalhadas, ao utilitarismo como critério de valoração moral para a escolha de alternativas possíveis. É o que se pretende expor no capítulo seguinte. 


\section{Utilitarismo, análise econômica do Direito e propriedade}

5.1. Noções gerais sobre utilitarismo

O utilitarismo pode ser definido como uma filosofia moral consequencialista que objetiva classificar como moralmente valorosa uma determinada ação a partir do critério de maximização da felicidade, comumente entendida como a superação da dor pelo prazer. (Posner, 1979, p. 111) Em outras palavras, o utilitarista é aquele que classifica como moralmente boa uma ação que produz maior utilidade agregada a uma determinada sociedade, entendendo-se (geralmente) como útil algo que produz prazer em detrimento da dor.

Stuart Mill, por sua vez, explicita que a crença de que a utilidade, ou o princípio da maximização da felicidade, seriam os fundamentos da moralidade, sustenta que as ações são corretas na medida em que intencionam promover a felicidade, e são erradas na medida em que intencionam produzir o reverso de felicidade. Por felicidade, esclarece Stuart Mill, compreende-se como o prazer e a ausência de dor; por infelicidade, dor e a privação do prazer. (Mill, 2001, p. 14)

No mesmo sentido, Jeremy Bentham aduz que uma ação está em conformidade com o princípio da utilidade quando a tendência que ela tem de aumentar a felicidade em uma determinada comunidade é maior de qualquer outra que ela tem de diminuí-la. Da mesma forma, alguma medida do governo será tida por conforme ao princípio da utilidade quando a tendência de aumentar a felicidade é superior à de diminuí-la. (Bentham, 2000, p. 15)

Para Posner, o utilitarismo é uma teoria que trata tanto da moralidade pessoal como da justiça social. Ou seja, um homem bom é aquele que busca maximizar a sua felicidade e a dos demais, assim como uma sociedade boa seria uma sociedade que objetiva, igualmente, maximizar a soma da felicidade geral (Posner, 1979, p. 111). Peñalver \& Alexander, no entanto, alertam que o utilitarismo, diferentemente, não se trata de um sistema de moralidade pessoal, mas, sim, de um sistema de decisão política e social, notadamente quando se trata de teoria da propriedade. (S. Alexander \& M. Peñalver, 2012, p. 12)

Dois pontos são fundamentais na teoria utilitarista: em primeiro lugar, porque sobre eles recaem a maior parte dos argumentos dos críticos a essa concepção; e, em 
segundo lugar - quiçá por consequência - referem-se aos aspectos de maior atenção teórica por parte de seus defensores. São eles: (i) como definir o que seria o bom (ou o útil) a ser almejado como critério de aferição do valor da decisão política ou social; e (ii) como agregar as experiências individuais relacionadas a essa utilidade para que seja possível a mensuração das escolhas tomadas.

O utilitarismo, como se viu acima, em sua clássica formulação por Jeremy Bentham apregoa que a escolha moralmente valorosa será aferida a partir da soma de todo o prazer, subtraída da dor, experimentado por todos de uma determinada sociedade. A decisão moralmente boa, portanto, será aquela que provocar a maior experiência de prazer líquido possível, em uma determinada sociedade. Ocorre, no entanto, que o critério do prazer não é unanimemente aceito por todos os utilitaristas, notadamente os mais recentes. Eis, portanto, uma primeira fonte importante de discussão.

\subsection{Breves linhas sobre a utilidade e a utilidade agregada}

Bentham assevera que a natureza situou a humanidade sobre a governança de dois mestres soberanos: dor e prazer. O padrão de certo e errado assim como as relações de causa e efeito estariam atadas ao trono de ambos os soberanos. Ou seja, tudo o que o ser humano faz, pensa ou fala está relacionado à dor e ao prazer. Nesse sentido, o princípio da utilidade reconhece essa sujeição do ser humano a ambos, e defende que o sistema de escolhas se fundamenta exatamente nesta sujeição (Bentham, 2000, p. 14). O utilitarismo, portanto, seria a forma de compreensão desse sistema pela razão.

O problema surge, todavia, quando se pretende definir o que seria o prazer. Ora, o prazer se refere a uma experiência individual vivenciada diferentemente por quem a experimenta. É, portanto, valorada particularmente e de diferentes modos. Como, diante disso, mensurar o prazer de modo a valorar como boa ou má uma determinada ação, sob a perspectiva utilitarista?

O utilitarismo, em sua versão clássica, procura valorar o prazer apenas em termos de intensidade e duração, evitando, assim, estabelecer critérios para definir o que seria propriamente um prazer relevante para fins de alcance de uma moralidade. Nesse contexto, surge a famosa assertiva de Jeremy Bentham: "prejudice apart, the game of push-pin is of equal value with the arts and sciences of music and poetry" (Bentham, 2008, p. 206) Ou seja, para Bentham, qualquer prazer advindo de ciências ou artes, como 
música e poesia, poderia ser igualmente valoroso ao prazer decorrente de um jogo infantil (push pin game).

A grande crítica à versão do utilitarismo de Bentham reside exatamente na possibilidade de tal concepção dar azo a que todo tipo de perversidade possa ser considerada como moralmente boa. Nesses termos, o prazer decorrente de um sadismo qualquer, por exemplo, poderia ser considerado como moralmente valoroso, caso, efetivamente, seja considerado prazeroso ao sádico que o pratica.

Stuart Mill, todavia, objetiva superar tal crítica ao argumentar que, considerada a natureza mais elevada do ser humano, é plenamente compatível com o princípio do utilitarismo o reconhecimento do fato de que alguns tipos de prazer são mais desejáveis e mais valorosos que outros. (Mill, 2001, p. 15)

A percepção de felicidade, portanto, é, de certo modo, individualista, pois está relacionada a uma experiência particular de uma determinada pessoa. Nesse sentido, a valoração moral de uma determinada conduta dependerá do impacto que será produzido individualmente na percepção da felicidade.

Bentham, como visto acima, defende que uma conduta será moralmente boa se a soma do prazer superar a dor produzida. O critério, então, seria o prazer líquido resultante da decisão e/ou da conduta.

Em uma concepção aproximada à de Bentham, mais modernamente, há o critério Kaldor-Hicks, que considera uma determinada decisão superior às alternativas se o benefício percebido por um determinado grupo de pessoas for suficiente para compensar as perdas do grupo que não foi beneficiado (ou prejudicado) pela decisão tomada. É de se notar que, para tais fins, não há que se efetivar, na prática, a compensação daqueles que forem prejudicados (ou não beneficiados) com a decisão. O critério Kaldor-Hicks considera que uma decisão será melhor que outra se o bem-estar geral for superior, independentemente da forma como os benefícios forem distribuídos. Na mesma linha, outro critério importante é o de Pareto, que considera que uma decisão é boa se ela torna pelo menos uma pessoa melhor sem decrescer a utilidade de ninguém.

A indiferença de tais critérios em relação aos aspectos distributivos é, de certa forma, temperada por alguns autores utilitaristas. O próprio Stuart Mill reconhece que, em certas hipóteses, devem ser considerados aspectos qualitativos dos grupos em relação aos quais as escolhas são feitas. Nesse sentido, assevera que seria melhor ser Sócrates insatisfeito do que um bobo satisfeito. (Mill, 2001, p. 18) Ou seja, ainda que, para efeitos do utilitarismo, sejam reconhecíveis os interesses de ambos, de Sócrates e do bobo, 
certamente dever-se-ia sopesar mais intensamente a satisfação de Sócrates. Dessa forma, não seria contrário ao utilitarismo a definição de alguns critérios distributivos que considerassem um peso maior aos interesses de determinados grupos em detrimento de outros.

5.3. Utilitarismo, análise econômica do Direito e direito de propriedade

\subsection{O utilitarismo e a análise econômica do Direito}

É importante destacar, desde já, que não é alheia a polêmicas a associação das teorias relacionadas à análise econômica do direito às concepções utilitaristas. Há autores, como, v.g., Peñalver e Alexander, que, para fins de delimitação temática sobre a concepção utilitarista de direito de propriedade, incluem no âmbito do utilitarismo as teorias autointituladas "economics" e "welfarists". (S. Alexander \& M. Peñalver, 2012, p. 11)

Outros autores, no entanto, como Richard Posner, traçam claras distinções entre economics e teorias utilitaristas. Aliás, Posner reputa a essas associações indevidas uma tentativa de se criticar indevidamente a análise econômica do direito por ele proposta. (Posner, 1979, p. 103)

Para o referido autor, as teorias utilitaristas puras têm como objetivo determinar como critério de definição de escolhas a maximização da felicidade ou bem-estar de uma determinada sociedade. Diferentemente, defende que, em sua análise, o critério a ser adotado deveria ser o de riqueza, entendendo-se como riqueza o valor em dólares (ou moeda equivalente) de tudo em uma sociedade. (Posner, 1979, p. 119). Em outras palavras, a análise econômica do direito comunga com o utilitarismo a adoção do consequencialismo como de valoração da conduta e das escolhas. Na medida em que o consequencialismo do utilitarismo está voltado para o alcance da maximização da felicidade (ou do bem-estar), o da análise econômica do direito está para a maximização da riqueza.

Nesse sentido, Posner assevera que os direitos, para a teoria econômica, não são outorgados por Deus ou por algo transcendental; são meros instrumentos de maximização de riqueza (Posner, 1979, p. 127). O fundamento maior da análise econômica do direito, portanto, é o princípio da maximização da riqueza, assim definido por Posner: 
To recapitulate, the wealth-maximization principle implies, first, an initial distribution of individual rights (to life, liberty, and labor) to their natural owners; second, free markets to enable those rights to be reassigned from time to time to other uses; third, legal rules that simulate the operations of the market when the costs of market transactions are prohibitive; fourth, a system of legal remedies for deterring and redressing invasions of rights; and fifth, a system of personal morality (the "Protestant virtues') that serves to reduce the costs of market transactions. Were the traditional common law fields to be reorganized along more functional lines, the first of these areas would be the domain of property law, the second of contract law, the third of tort law, and the fourth of procedural and remedial (including criminal) law. (Posner, 1979, p. 127)

Não se ignora que, posteriormente, notadamente a partir da década de 90, Posner tenha feito diversas concessões aos seus críticos, de modo, inclusive, a colocar em segundo plano o princípio da maximização da riqueza como um norte essencial ao Direito. A partir de então, Posner se aproxima do pragmatismo jurídico, ao defender que o Direito tem como fim não exclusivamente a maximização de riqueza, mas, efetivamente, o alcance de fins sociais. Tais fins sociais, assim como as realizações humanas, devem ser apreciados relativamente às circunstâncias e avaliadas também por suas consequências. (Salama, 2008, p. 12)

A concepção fundamental de Posner tem profunda inspiração nos trabalhos desenvolvidos por Ronald Coase. Reputa-se ao trabalho de Coase a origem da versão mais atual da análise econômica do direito, especialmente em seu artigo de 1960 acerca do problema dos custos sociais (Coase, 1960). Em seu texto, Coase promove uma análise da sistematização e alocação de direitos em um contexto de discussão acerca da aplicação da nuisance doctrine, ou seja, em hipóteses em que se discute os efeitos - e as respectivas consequências jurídicas - em terceiros, de atividades de empresas, como, por exemplo, uma fábrica que produz fumaça capaz de trazer prejuízos à vizinhança.

Em seu famoso artigo, Coase defende que devem ser levados em consideração os custos relacionados às operações existentes no âmbito dos arranjos sociais. Nesse sentido, deve-se considerar que as escolhas entre arranjos sociais e, portanto, de alocação de direitos, envolvem custos a serem suportados, que poderão resultar em prejuízos a alguns 
grupos determinados, apesar de eventuais melhorias provocadas pelas decisões tomadas. Nesse contexto, o desejável seria que as escolhas e ações desenvolvidas provocassem ganhos superiores às perdas verificadas, considerando o efeito total dentro de um sistema. (Coase, 1960, p. 44)

Ao explicitar a lógica econômica existente na nuisance doctrine, Coase criou uma premissa de análise que foi estendida a outras áreas do direito, resultando, assim, em uma concepção teórica econômica-jurídica que parte do pressuposto de que um sistema legal teria (ou racionalmente deveria ter) como finalidade, a promoção da alocação eficiente de recursos

A teoria da propriedade no âmbito do utilitarismo e da análise econômica do direito difere, portanto, das demais teorias analisadas, exatamente por compreender a propriedade como um instrumento para se alcançar um determinado fim pretendido.

Nesse sentido, a teoria utilitarista é comumente diferenciada das teorias que têm fundamento em um direito à propriedade (rights-based theories), como, v.g., as teorias de Jeremy Waldron (Waldron, 2002), Robert Nozick (Nozick, 2011), e Hegel (Hegel, 2009), assim como se diferencia das teorias de propriedade baseadas em um dever, como, por exemplo, Immanuel Kant (Kant I. , 2014). Em relação às primeiras, a teoria utilitarista se diferencia por não fundamentar o direito à propriedade em qualquer interesse individual que deva ser protegido (seja por qualquer argumento de natureza moral, transcendental ou religiosa). Em relação às segundas (duty-based), as teorias utilitaristas se diferenciam por não pressupor nenhum dever inerente ao direito de propriedade (como, p. ex., a obediência a uma lei universal, origem de todo sistema de direitos). De fato, como se viu acima, o fundamento maior da propriedade utilitarista é a maximização do bem-estar (ou felicidade) ou, ainda - para a análise econômica do direito - a maximização da riqueza.

Para a concepção da análise econômica, o sistema legal deveria ser considerado como um instrumento norteado para a maximização de riqueza. Uma norma, uma conduta ou um contrato são bons quando maximizam riqueza (considerando os efeitos agregados no total).

5.5. As dimensões positiva e normativa da análise econômica do Direito

A análise econômica do direito costuma ser subdivida em duas dimensões: a) a dimensão positiva, que tem por objetivo analisar situações específicas de uma realidade posta; e b) a dimensão normativa, que tem por objetivo promover análises prospectivas, 
voltadas, portanto, para eventuais reformas no âmbito do sistema legal, a partir das relações entre direito e justiça e ideias de eficiência econômica, maximização da riqueza ou do bem-estar (Salama, 2008).

A dimensão positiva da análise econômica do direito fundamenta-se na ideia de que os instrumentos de análises advindos de teorias econômicas poderiam agregar relevantes explicações à análise do direito e dos efeitos de sua aplicação. De fato, Posner, a esse respeito, defende que os economistas tenderiam a ser mais treinados, comparativamente a outros cientistas sociais, em métodos modernos de análises quantitativas, o que poderia ser útil na análise de sistemas legais. Adicionalmente, os economistas teriam mais ferramentas para descobrir e usar métodos estatísticos no âmbito de sistemas legais, assim como seriam mais sensíveis a problemas qualitativos relacionados a inferências que poderiam decorrer de informações estatísticas (Posner, 1975, p. 766).

A dimensão normativa, como visto acima, tem por objetivo, pela análise econômica do direito, promover uma reflexão acerca de arranjos institucionais e sistemas legais a partir da relação entre direito e justiça e eficiência econômica, maximização da riqueza ou do bem-estar.

Nesse contexto, os escritos originais de Posner, ao situar a maximização de riqueza como princípio ético que fundamenta o próprio Direito, constituem o posicionamento mais radical da dimensão normativa da análise econômica do Direito. A perspectiva normativa, portanto, objetiva analisar as instituições e os sistemas legais como instrumentos para se atingir o fim preconizado pela análise econômica do direito, qual seja, a maximização da riqueza, em sua versão mais pura.

Como acima referido, Posner acabou fazendo algumas concessões aos seus críticos, norteando, posteriormente, sua teoria ao pragmatismo jurídico. Nessa versão menos radical da análise econômica do Direito, abandona-se a ideia de que a maximização da riqueza seria um bem em si mesmo a ser perquirido como um princípio ético, em benefício de uma perspectiva sobre o Direito mais permeável a valores distintos e fundados em outros princípios morais.

Nessa linha, objetiva-se não mais defender um princípio ético consubstanciado na maximização da riqueza, mas sim analisar as consequências econômicas que decorrem da adoção de um determinado arranjo institucional, um posicionamento legal (ou normativo) ou, ainda, de uma decisão judicial. Analisa-se o Direito, ao regular as relações sociais, políticas e econômicas, como um instrumento para a concretização de políticas 
públicas. Essa perspectiva, portanto, almeja fornecer ferramentas para que seja possível (i) a definição de uma determinada política pública ou de uma decisão judicial ou normativa; (ii) analisar quais as consequências efetivas das alternativas existentes e (iii) o adequado posicionamento dos arranjos institucionais necessário para o alcance dos fins almejados.

5.6. Conceitos e assunções relevantes das teorias econômicas do Direito: uma análise da Tragédia dos Comuns

Poder-se-ia assumir que o modelo básico original de análise econômica do Direito tem como referência o contexto hipotético suscitado por Garret Hardin - descrito no início deste trabalho - na denominada Tragédia dos Comuns (Hardin, 1968). No cenário proposto por Hardin, como visto, trata-se de um sistema (fechado) no qual há vários agentes racionais, recursos limitados e decisões a serem tomadas no que concerne à alocação de recursos.

A principal provocação de Hardin reside na contradição entre os benefícios individualmente percebidos em decorrência de uma decisão particular de maximização de ganho (acréscimo de uma res no pasto comum) e os prejuízos causados pelo consumo adicional do pasto, prejuízos esses que seriam suportados pela coletividade.

Os referidos prejuízos percebidos na Tragédia dos Comuns estão, como visto acima, em algumas transações, alheios (ou subdimensionados) no âmbito da análise de custo-benefício realizada pelo agente individual. No caso explicitado por Hardin, a análise de custo-benefício individualmente realizada considera o valor agregado em decorrência da adição de um animal em contrapartida ao custo dessa decisão, que é suportado (dividido) por todos os outros agentes.

A esse efeito, percebido por terceiros alheios a uma determinada transação, atribui-se a denominação de externality, que pode ser conceituada, por elementos trazidos por Harold Demsetz, como sendo os custos ou benefícios, pecuniários ou não pecuniários, externos a uma determinada transação e aos agentes diretamente envolvidos. (Demsetz, 1967, p. 348)

Demsetz, em seu artigo, defende que, para se evitar a tragédia exposta por Hardin, deve-se, tanto quanto possível, "internalizar" as referidas externalidades, de modo que uma determinada decisão possa ser tomada a partir de uma análise efetiva de custobenefício que contemple, adequadamente, todos os efeitos decorrentes da transação 
pretendida. Nesse sentido, assevera que uma função primária dos direitos de propriedade é a de promover incentivos para se alcançar uma maior internalização das externalidades. (Demsetz, 1967, p. 348)

Nessa linha, Demsetz defende que a propriedade privada da terra, para se ater ao exemplo formulado por Hardin, resultará na internalização de vários custos externos associados à propriedade comunitária, porquanto o proprietário, munido de seu direito de excluir terceiros, pode, geralmente, contabilizar e gerenciar melhor os seus recursos. Para Demsetz, essa concentração de custos e benefícios em proprietários tem o condão de incentivar a utilização mais eficiente dos recursos. (Demsetz, 1967, p. 356)

Demsetz, portanto, ao discutir a problemática trazida por Hardin, propõe que a propriedade privada pode ser considerada uma forma eficiente de se evitar o problema do consumo excessivo de recursos demonstrado no âmbito da tragédia dos comuns.

Ocorre que o consumo excessivo de um recurso de livre acesso não é a única externalidade que poderia resultar em tragédia, no modelo básico de Hardin. De fato, deve-se considerar, igualmente, a tragédia do free rider. Para se ater ao exemplo suscitado, imagine-se que, para se alcançar uma boa produtividade na criação de animais, os agentes devem empregar esforços individuais, em benefício comum, consistentes, por exemplo, no adequado preparo da terra para o pasto, na aposição de cercas no terreno, para evitar a fuga dos animais, etc.

Nesse contexto, o agente racional poderá avaliar que o benefício concreto por ele percebido, em decorrência de seu exclusivo esforço para o cumprimento das referidas tarefas, poderá ser inferior aos benefícios advindos dos esforços dos demais vis-à-vis com sua conduta omissiva. Ou seja, o prejuízo individualmente verificado, por sua conduta omissiva (não cumprir com suas obrigações de fazer), poderá ser menor - pois por todos será suportado indistintamente - aos esforços individualmente considerados para o cumprimento de suas tarefas. Poderá, portanto, o free rider, pegar uma "carona" nos benefícios advindos com os esforços de todos e assumir um pequeno prejuízo, correspondente à sua quota-parte, decorrente de sua desídia.

$\mathrm{Na}$ visão macro do sistema, a conduta do free rider, no entanto, gera improdutividade e torna o resultado menos eficiente. E, ainda, considerando que todos os agentes são racionais e, igualmente poderiam realizar a mesma avaliação de custobenefício, o resultado, no curso do tempo, seria, novamente, uma tragédia por uma redução drástica da produtividade. 
Em que pesem as importantes análises que decorrem do modelo apresentado por Hardin, deve-se considerar que as conclusões formuladas, a partir do cenário por ele posto, partem de algumas premissas fundamentais para análise econômica das condutas em questão. Tais premissas estão frequentemente presentes nas teorias de análise econômica do Direito e são extremamente importantes para a compreensão, de um lado, da utilidade de tais teorias e, de outro, de suas limitações.

A teorias relacionadas a Economia e Direito, geralmente e principalmente em suas versões iniciais, partem do pressuposto de que os modelos de análise são integrados por agentes absolutamente racionais que têm como princípio básico de atuação o alcance da maximização de sua própria riqueza. Sob o ponto de vista pessoal, portanto, os referidos agentes buscam o maior ponto de eficiência para a sua equação particular de custobenefício. Nesse modelo ideal, não há espaço para nenhuma outra ação que não tenha por finalidade a maximização da riqueza, como, por exemplo, decisões que estejam norteadas por propósitos altruístas.

No caso da Tragédia dos Comuns, a premissa do agente racional, como visto acima, invariavelmente resultará no consumo exagerado dos recursos comuns, com a adição de mais animais, por decisões tomadas individualmente a partir de uma análise de custo-benefício particular.

No âmbito dessa linha de pensamento, todos os partícipes de um sistema jurídico (partes em um contrato, criminosos, órgãos acusatórios, motoristas de automóveis, para utilizar os próprios exemplos de Posner) são agentes racionais e agem inteligentemente para maximizar as suas próprias satisfações. (Posner, 1975, p. 763)

Nesse contexto, e em um sistema legal, os conceitos de "bens" e os respectivos "preços" são não convencionais. Ou seja, a título de ilustração, para um criminoso, o "bem" pode ser a prática de um determinado crime e o "preço" pode ser a probabilidade de condenação.

Para se ater ao exemplo de Posner, nessa linha de pensamento, defende-se que o aumento dos custos esperados (ou projetados) em decorrência da prática de um crime como, por exemplo, o aumento na gravidade da punição ou na probabilidade de ser ela imposta - resultarão na redução na quantidade de crimes. (Posner, 1975, p. 763) Contrariamente, caso exista uma percepção de impunidade e de aplicação branda das penas, o criminoso, nesse modelo racional, avaliará que o custo relacionado à prática de crimes é baixo; e, seguindo essa linha de raciocínio, tenderá a continuar (ou aumentar) a 
prática delitiva sempre que os benefícios dela decorrente superarem os custos (diminuídos, neste caso) relacionados à punição e respectiva probabilidade.

Não se deve negar a utilidade desse modelo de análise, ao se tentar medir e realizar prognósticos em relação a possíveis consequências advindas da ação egoística de maximização da riqueza em determinados cenários. Por outro lado, não se deve adotar a decisão do agente racional maximizador de riqueza como uma lei universal e apriorística.

Diante dessa percepção, surgem, mais recentemente, diversas teorias que incluem elementos comportamentais na análise econômica do Direito. A propósito, digno de nota é o trabalho desenvolvido por Ernst Fehr, Urs Fischbacher e Simon Gächter (Fehr, Fischbacher, \& Gächter, 2002). De fato, os referidos autores demonstram, com relevantes fundamentos empíricos, que, em determinados arranjos sociais, as decisões dos agentes não são, necessariamente, orientadas a partir de critérios de maximização da eficiência na equação individual de custo benefício. Argumentam que, em algumas situações, os agentes tendem a tomar decisões que resultam em aumento de custos, ou perda de benefícios, em função de critérios norteados por uma ideia de reciprocidade (strong reciprocity), altruísmo ou altruísmo recíproco.

A título de ilustração de uma hipótese bastante comum de que em determinadas situações agentes tendem a reforçar condutas de reciprocidade em detrimento de ações de maximização da riqueza, é de se destacar o exemplo do troco pela utilização de serviços de táxi. Deve-se notar que o exemplo mencionado trata de uma situação caracterizada por uma única interação entre os agentes - motorista de táxi e usuário do serviço (esse tipo de situação é denominado de one-shot prisoner dilema, por retratar a baixa probabilidade de ocorrência de outras interações entre os agentes) (Fehr, Fischbacher, \& Gächter, 2002, p. 7). Nessa hipótese, é relevante considerar que existem os custos e benefícios para o passageiro evadir-se do táxi sem efetivar o pagamento da corrida, bem como os custos e benefícios de uma posterior perseguição, por parte do motorista, do passageiro que se evadiu.

No caso mencionado, os benefícios econômicos do passageiro para se evadir sem efetivar o pagamento são relativamente maiores aos custos decorrentes da fuga. Por outro lado, sob a perspectiva do taxista, os custos de uma perseguição seriam relativamente maiores aos benefícios eventualmente advindos com a abordagem do passageiro fugitivo. Ou seja, se as ações de ambos os agentes fossem orientadas a partir do princípio da maximização da riqueza (ou pelo alcance da máxima eficiência), o passageiro tenderia a se evadir sem pagar e o taxista não iria promover qualquer tipo de perseguição. 
Na prática, no entanto, conforme esclarecem os referidos autores, as pessoas são inclinadas a realizar o pagamento pelo serviço do táxi - muito embora pudessem se evadir a um custo baixo - e os taxistas, em uma hipótese de fuga do passageiro, ficariam extremamente aborrecidos com o fato e, em consequência, tenderiam a efetivar uma perseguição para alcançar o passageiro e puni-lo - apesar do alto custo de uma perseguição se cotejada com os benefícios potencialmente advindos com seu sucesso. (Fehr, Fischbacher, \& Gächter, 2002, p. 8)

O exemplo em questão demonstra que há situações em que os agentes são norteados a agir no sentido de reforçar positivamente uma conduta, assim como a reforçar negativamente outras, em critérios de reciprocidade, ainda que a análise de custobenefício indique atuações em sentido contrário. Em outras palavras, há ocasiões em que as pessoas demonstram disposição a dispender recursos para reforçar positivamente (incentivar) ou reforçar negativamente (punir) uma determinada conduta, ainda que não ocorram futuras interações entre os referidos agentes (one-shot PD).

O trabalho desenvolvido pelos referidos autores, portanto, desafia o modelo ideal do agente racional que sempre objetiva alcançar o máximo de eficiência econômica em suas ações, bem como demonstra que outros critérios, como reciprocidade, podem ser relevantes para a efetivação de uma determinada norma (enforcement), em estruturas sociais específicas.

Outras teorias mais recentes questionam a fidedignidade do caráter racional do agente, a partir da compreensão de que a racionalidade humana é, efetivamente, limitada. Nesse sentido, deve-se mencionar o trabalho desenvolvido por Oliver Williamson, no âmbito do que se denomina Transaction Cost Economics (“TCE”) (Williamson, 2007)

Para a TCE, os agentes humanos são descritos como racionalmente limitados. Tal perspectiva objetiva se contrapor às teorias neoclássicas que partem do pressuposto de que as decisões humanas são tomadas por uma racionalidade econômica extremamente aguçada, o que induz a uma análise pautada na premissa de que as reações humanas, diante de um determinado evento, sejam norteadas por pura lógica e racionalidade. Ao contrário, para a TCE, deve se considerar uma capacidade de "prevenção viável" que permite que as partes antevejam eventuais riscos e, na medida do possível, instrumentalizam mecanismos de mitigação, para, em seguida, poderem estipular obrigações viáveis.

Para os propósitos da TCE, portanto, os agentes possuem uma racionalidade limitada, o que significa afastar uma noção de "hiper-racionalidade", assim como, por 
outro lado, uma ausência absoluta de racionalidade. Essa perspectiva resulta na conclusão de que a capacidade de "prevenção viável" permite que riscos contratuais sejam mitigados na medida da possibilidade, o que, invariavelmente, faz com que contratos complexos se tornem incompletos. Ou seja, para essa perspectiva, não se deve partir da premissa de que os agentes são sempre capazes de prever e mitigar, apropriadamente, todos os riscos a que determinada atividade está sujeita.

Além da limitação racional, que é reconhecida pela TCE como aspecto importante a ser considerado na análise contratual e das estruturas de governança que regem determinada atividade, deve-se considerar, igualmente, os efeitos do oportunismo do comportamento humano. São dois, portanto, os elementos relativos à conduta humana que são considerados como relevantes para efeitos da análise desenvolvida pela TCE: oportunismo e racionalidade limitada. De fato, teorias da organização que não consideram ambos os aspectos terão uma visão prejudicada acerca dos perigos que poderão afetar determinada transação.

Verifica-se, em conclusão, portanto, que as premissas que resultam na Tragédia dos Comuns podem, na prática, ignorar outros aspectos relevantes do comportamento humano, diante de determinados arranjos institucionais. O agente racional idealizado, apesar de permitir análises importantes acerca de consequências econômicas de decisões tomadas, não corresponde, necessariamente, ao que se verifica na prática, diante da complexidade das relações sociais e econômicas, além da própria limitação humana. Aspectos morais, culturais, sociais e políticos também interferem significativamente nos resultados dos arranjos institucionais.

Outra premissa importante adotada por Hardin se refere à ideia do consumo rivalizado dos recursos, de modo que o consumo excessivo por parte de um determinado agente retiraria a disponibilidade, na mesma proporção, aos demais. Ora, é de se notar que nem todo sistema de consumo de recursos segue, necessariamente, a essa mesma lógica. No caso do consumo de informação, por exemplo, o acesso de um determinado agente não obsta a disponibilidade desse recurso a qualquer outro interessado. Nesse sentido, os aspectos econômicos e jurídicos a serem sopesados no contexto da propriedade intelectual, por exemplo, são totalmente distintos daqueles examinados no modelo ideal de Hardin. Presumir, portanto, que todo sistema de alocação de recursos se assemelha aos "comuns", acima retratados, seria uma diminuição relevante de uma realidade extremamente mais complexa. 
Por fim, deve-se atentar, ainda, ao fato de que o modelo idealizado por Hardin trata de um cenário caracterizado pelo acesso aberto aos recursos, de modo que cada um, individualmente, pode tomar a decisão de consumir mais ou menos do que se encontra disponível. Demsetz, como visto acima, diante deste contexto, objetiva evitar a tragédia ao instituir uma internalização das externalidades, ao atribuir, por força da propriedade privada, o poder de decisão sobre o consumo dos recursos a um determinado titular do domínio.

Ocorre que o problema da alocação de recursos pode ser retratado de inúmeras formas, em contextos distintos do modelo ideal de acesso livre. A alocação de recursos, conforme nos esclarecem Guido Calabresi e Philip Bobbitt, pode se dar pelo mercado, por decisões políticas, pelos costumes, por sorteio ou por diversos arranjos entre os referidos modelos (Calabresi \& Bobbitt, 1978). De fato, conforme bem apontado pelos autores em questão, a escassez (e, portanto, a exclusão) são fatos da vida (Calabresi \& Bobbitt, 1978, p. 22). A tragédia, no entanto, residirá nas decisões acerca da alocação dos recursos e, principalmente, na sua fundamentação vis-à-vis aos valores morais aceitos em uma determinada sociedade.

Adicionalmente, deve-se reconhecer que a tragédia apresentada por Hardin trata, a rigor, de um contexto no qual os custos envolvidos na produção são compartilhados coletivamente e os benefícios são privados e percebidos individualmente. Trata-se de um arranjo institucional específico. Dessa forma, qualquer generalização açodada dos efeitos a serem verificados em situações de recursos escassos pode levar a gritantes equívocos.

Nesse sentido, as teorias de análise econômica do Direito podem, ao absorverem críticas atinentes a seus modelos pré-concebidos e premissas, fornecer ferramentas relevantes de análise que permitam, inicialmente, uma compreensão dos contextos institucionais, para que seja possível a análise dos efeitos das decisões tomadas no âmbito daquele contexto determinado, assim permitindo proposições mais consentâneas com a realidade institucional.

\subsection{Críticas ao utilitarismo e às concepções econômicas do Direito}

Conforme já delineado acima, uma das principais dificuldades das concepções utilitaristas reside exatamente na definição do que seria a maximização da felicidade. Como visto, a concepção original do utilitarismo defende que a felicidade, como fim 
absoluto a ser buscado, deveria ser considerada como o prazer menos a dor resultantes de uma determinada conduta.

Ocorre que, tal como aponta Posner, decorre dessa concepção de Mill uma incerteza relevante a respeito da definição de prazer (ou felicidade). De quem seria a concepção de felicidade (ou prazer e dor) que nortearia as decisões políticas para maximização da felicidade? (Posner, 1979, p. 112) Dessa problemática surgem questões concretas e, ainda hoje, relevantíssimas. Ora, como se deve sopesar a felicidade dos estrangeiros para fins de estabelecimento de políticas públicas? E a felicidade dos ainda não nascidos?

A propósito, Posner traz os seguintes exemplos: a) se a metade mais pobre da população de Bangladesh fosse exterminada, o padrão de vida, e consequentemente a felicidade, da população remanescente, iria aumentar diante da melhoria da razão entre recursos naturais escassos e o número de pessoas. A felicidade total, todavia, poderia ser menor. b) igualmente, uma alta taxa de natalidade poderá causar uma diminuição do padrão de vida da população em geral de um determinado país, e, consequentemente, da média da felicidade das pessoas. Essa perda, no entanto, poderá ser compensada pelas satisfações das pessoas acrescidas.

As dificuldades decorrentes da aferição da felicidade na concepção utilitarista ensejam o que se denomina de monstruosidade moral da teoria utilitarista. Imagine, a propósito, que uma pessoa A tenha prazer em arrancar asas de moscas. Por outro lado, a pessoa B se sente feliz ao alimentar pombos. Se A tiver capacidade de produzir uma maior quantidade de prazer ao arrancar as asas das moscas do que B ao alimentar pombos, sob critérios utilitaristas de maximização da felicidade, dever-se-ia julgar a A e sua conduta moralmente melhor do que B.

Adicionalmente, o utilitarismo pode resultar em sacrifícios individuais em benefício de uma maioria. A esse respeito, Alan Donagan traz o seguinte exemplo: eventualmente se poderia resultar em mais efeitos benéficos do que malefícios do assassinato sem dor e indetectável do seu malicioso, velho e infeliz avô, se comparado ao fato de ter que suportá-lo até a sua morte natural. (Donagan, 1994, p. 133) Ou seja, a teoria utilitarista poderia, em tese, considerar moralmente boa a conduta consistente em um assassinato, na hipótese de se verificar que os efeitos resultantes da morte da vítima levariam a uma maximização da felicidade de uma maioria, apesar do trágico fim de uma determinada pessoa. 
Levando a argumentação a posições extremas, poder-se-ia defender a tese de que o utilitarismo eventualmente considere como adequada a conduta ocorrida na Alemanha nazista de extermínio de uma minoria de judeus, caso se entenda que a eliminação de um determinado grupo social poderia maximizar a felicidade de uma maioria intolerante. (Posner, 1979, p. 117)

As teorias utilitaristas, portanto, tendem a ser alvo de críticas relacionadas aos direitos individuais, notadamente considerando os grupos que saem perdedores na conta final relativa à felicidade agregada. A dor de uns poucos pode não ser suficiente para contrabalançar a felicidade da maioria, em uma análise a partir do critério Kaldor-Hicks, o que poderia tornar moralmente valorosa uma conduta absolutamente reprovável e cruel.

Da mesma forma, as teorias utilitaristas de Direito de propriedade também confrontam perspectivas kantianas de liberdade e de moralidade. Posner, a propósito, considera como fanático aquele que leva às últimas consequências o imperativo categórico. Sobre o tema, Posner assevera que "se o perigo do utilitarista é a monstruosidade, os do teórico kantiano são a repulsa moral exacerbada e o fanatismo." (Posner, 1979, p. 117)

Posner tenta, inicialmente, superar a falta de critério do utilitarismo original ao estabelecer a riqueza (ou a quantificação em dólares) como critério de definição de valor de uma determinada conduta (Posner, 1979, p. 119). Assim, reduz-se o subjetivismo e o autoritarismo na estipulação do que deveria ser considerado como prazer o que deveria ser considerado como dor.

A partir da adoção deste critério como norte moral de uma determinada conduta, o "monstro utilitarista" não teria lugar em um sistema ético fundamentado maximização da riqueza (Posner, 1979, p. 131). De fato, voltando ao exemplo mencionado, assevera Posner que "se a Alemanha nazista quisesse se livrar dos judeus, em um sistema de maximização da riqueza, seria obrigada a comprá-los. " (Posner, 1979, p. 133)

O próprio, Posner, conforme já explicitado, abandonou essa versão mais radical relativa à criação de um sistema ético fundamentado exclusivamente no princípio da maximização da riqueza, tendo adotado, em substituição, uma perspectiva mais pragmática do Direito.

Outro ponto relevante em relação às concepções econômicas do Direito se referem à tendência de estipularem um critério único de medida do interesse (v.g., prazer, dor ou dólar). A partir desse critério único de medida, poder-se-ia considerar como intercambiáveis quaisquer interesses. Em últimas consequências, a título de ilustração, 
parte-se do pressuposto de que a perda de um parente próximo pode ser quantificada e substituída/compensada por alguma quantidade em dinheiro ou em prazer.

A referida premissa ignora que a valoração de experiências, costumes, relações e até bens materiais é realizada individualmente, a partir de critérios muitas vezes não coincidentes com os de outros indivíduos. Tal aspecto, na prática, torna obscura uma realidade extremamente mais complexa.

É de se notar que essa concepção contrasta com a perspectiva hegeliana de que a propriedade deveria ser considerada como uma decorrência da exteriorização de uma individualidade livre.

\subsection{Breves comentários acerca das contribuições das teorias econômicas do Direito}

As teorias utilitaristas e econômicas do Direito, como já exposto acima, sofreram severas críticas principalmente ao tentar alcançar uma teoria de Justiça fundamentada em um ideal ético, seja norteado no sentido de maximização da felicidade, seja de maximização da riqueza - tal como, inicialmente, havia sido proposto por Posner. Basicamente, o princípio ético que fundamenta uma teoria de Justiça utilitarista tenderá a mitigar individualidades e, eventualmente, a restringir direitos de minorias perdedoras na conta do valor agregado de utilidade. Cedo ou tarde, o utilitarista se defrontará com questões éticas relacionadas a direitos individuais fundamentais que não se prestam à balança da utilidade agregada. Em tais situações, o utilitarista será moralmente compelido a posicionar-se a partir de critérios de valoração moral de índole subjetiva ou, ainda, sujeitar-se a concordar com consequências passíveis do enquadramento na pecha de "monstruosidades" - para utilizarmos a terminologia de Posner.

Isso não significa, todavia, que não se possam colher relevantes contribuições das análises econômicas sobre a aplicação do Direito e sobre arranjos institucionais.

Ainda em 1975, Posner apontava algumas contribuições que a análise econômica do Direito poderia trazer. A primeira delas se refere ao fato de que os participantes em um processo legal, como, v.g, criminosos, acusadores, motoristas, partes contratantes, agiriam com propósito de maximizar os seus próprios interesses. (Posner, 1975, p. 763) Essa análise, pressupunha um cálculo de custo-benefício envolvido em cada uma das ações por parte desses participantes.

Demonstrou-se que a premissa do agente racional não pode ser tomada como uma verdade absoluta, no sentido de explicar a conduta humana. Diversos fatores interferem 
nas decisões tomadas em cada circunstância específica. Esse fato, entretanto, não retira a credibilidade de uma análise a respeito de quais seriam as consequências econômicas na hipótese de, eventualmente, uma análise de custo-benefício de uma ação influir na decisão da conduta.

De fato, recentemente, o Supremo Tribunal Federal, ao decidir a respeito da possibilidade de se efetivar o cumprimento da pena antes do trânsito em julgado da sentença penal condenatória, perpassou, entre os diversos fundamentos que sustentaram a posição adotada, pela necessidade de tornar mais efetiva a sanção criminal como forma de coibir a prática delitiva. (HC 126292, Relator: Min. TEORI ZAVASCKI, DJe17.5.2016)

Verifica-se, portanto, que, subjacente ao argumento, há a percepção de que o criminoso, ao realizar uma análise de custo-benefício, a partir da mensuração, de um lado, da efetividade/probabilidade da sanção penal, e, de outro, de eventuais benefícios advindos da prática delitiva, tenderá a perceber um maior peso na balança punitiva, o que resultará na diminuição da criminalidade.

Evidentemente que essa análise poderá não surtir nenhum efeito em determinadas situações específicas, por exemplo, nos chamados crimes passionais, que, via de regra, não indicam haver mensuração de quaisquer consequências decorrentes de uma conduta criminosa. Essa constatação, no entanto, não invalida a análise em relação a outras condutas criminosas, como, v.g., nos denominados crimes de "colarinho branco".

Não deixa de ser relevante, portanto, o entendimento de critérios econômicos para avaliação de determinados arranjos institucionais. Referido aspecto se revela ainda mais importante quando se trata da análise de condutas empresariais ou de partes em um contrato. Nessas hipóteses, como regra geral, o que se objetiva é exatamente o alcance de uma máxima eficiência econômica para cada uma das partes.

No que concerne ao direito de propriedade, a busca na eficiência econômica poderá resultar em significativos impactos nas decisões acerca da alocação de determinados recursos.

A propósito do tema, Guido Calabresi e A. Douglas Melamed trazem relevantíssimas contribuições a respeito de critérios a serem adotados em hipóteses em que se está em jogo a utilização plena de um direito de propriedade vis-à-vis o direito de outros indivíduos que seriam afetados por determinado uso da propriedade (Calabresi \& Melamed, 1972). Alertam, no referido trabalho, que, em termos de direito de propriedade, algumas decisões coletivas (ou pelo Estado) devem ser tomadas, por exemplo, em relação 
a quem pode fazer barulho e quem teria o direito ao silêncio, quem poderia poluir e quem deveria ter respeito ao direito de respirar ar puro. (Calabresi \& Melamed, 1972, p. 1090)

Os citados autores defendem que, para que seja possível a obtenção de uma decisão adequada a respeito do problema de alocação de recursos, devem ser sopesados aspectos referentes às consequências econômicas das decisões tomadas. Para tal desiderato, a busca pela eficiência econômica pode, efetivamente, indicar um caminho a ser trilhado, inclusive para o reconhecimento (e quantificação econômica) dos direitos eventualmente preteridos na escolha da alocação de recursos.

A evolução das teorias da análise econômica do Direito tem permitido reflexões a respeito de políticas públicas, arranjos institucionais e seus impactos nas sociedades. Nesse aspecto, relevantes são as contribuições de Douglas North em sua teoria institucional, com suas análises sobre o papel das instituições no desenvolvimento das sociedades.

De fato, tal como assevera North, a análise do desenvolvimento econômico das sociedades deve estar intimamente relacionada à compreensão do exercício de liberdades e garantias relacionadas ao exercício de atividades civis, políticas, religiosas e econômicas. A aplicação (enforcement) das referidas garantias e liberdades constitui um elemento fundamental no desenvolvimento econômico e social. Nesse sentido, o entendimento a respeito do papel das instituições para tais finalidades é essencial, pois, segundo North, "institutions are at the heart of a meaningful understanding of freedom and determine transaction costs in a society". (North, 1988, p. 4)

Autores mais recentes, como Marcus Faro de Castro, com base na compreensão das limitações das teorias de Law \& Economics, de um lado, e, de outro, das relacionadas às teorias puras e formalistas de Direito, objetivam construir análises jurídicas com a inclusão de elementos interdisciplinares na avaliação de determinadas decisões políticas. Elementos de Justiça e Direito são integrados na análise das políticas públicas, como aspectos tão relevantes quanto critérios de eficiência econômica.

Pretende, o referido autor, formular uma ferramenta de análise de políticas econômicas a partir do entendimento de que a justiça econômica não se restringe à promoção da efetividade, mas também da fruição equânime dos direitos humanos fundamentais. (Castro, 2009, p. 49)

O trabalho de Castro demonstra que análises quantitativas e qualitativas de fruição de direitos podem se tornar instrumentos relevantes para a compreensão, formulação e 
aperfeiçoamento de políticas públicas, a partir, não apenas de critérios econômicos, mas, também, de Justiça e equidade na fruição de direitos.

Verifica-se, portanto, que são vastos os campos ainda a serem explorados por meio das ferramentas advindas das teorias de Law \& Economics. Ao se superar o fetichismo relacionado à construção de uma teoria ética de Justiça fundamentada na eficiência econômica, os autores desse ramo do Direito passam a desenvolver importantes contribuições à compreensão das interações entre o Direito e a economia. 


\section{A Constitucionalização do Direito de Propriedade}

\subsection{A constitucionalização do Direito Civil}

O processo de codificação - representado pelo Código Napoleão como seu texto mais emblemático - pode ser considerado como um subproduto do liberalismo clássico e das pretensões iluministas de se compreender a realidade social por critérios científicos herméticos e definidos aprioristicamente pela racionalidade humana.

De fato, a ideia de um código nos remete a um documento único que contém disposições normativas sobre um determinado tema, organizadas sistematicamente e de modo a contemplar a totalidade das prescrições relacionadas ao assunto por ele regulado, com o propósito de constituir uma disciplina jurídica completa e suficiente. Assim, o processo de codificação civilista verificado no século XIX teve como propósito dispor, em um só texto completo e autossuficiente, sobre toda a normatização referente às relações regidas pelo Direito Civil.

A ideia de codificação das normas de direito privado em um só texto, dissociandoo de tudo o mais a que se disser respeito às funções do Estado, nos remete, novamente, à dicotomia direito público/direito privado. Essa sistematização, assim como recorda Flávio Tartuce, remonta ao Digesto, no Corpus Juris Civilis, que promoveu a divisão entre ius publicum e ius privatum, sob critérios de utilidade da lei. Ou seja, se a lei representar utilidade pública, tratar-se-ia de direito público; se a lei dispor sobre utilidades particulares, seria de direito privado. (Tartuce, 2016, pp. 56-57)

José Carlos Moreira Alves pondera, todavia, que o que interessa ao Estado também é do interesse de seus cidadãos, e a recíproca é verdadeira. Por essa razão, admite-se que Ulpiano, ao estipular a divisão entre ius publicum e ius privatum, estaria se referindo à função imediata das normas jurídicas. Assim, as que interessam imediatamente ao Estado e apenas mediatamente aos cidadãos seriam classificadas como ius publicum; e, ao contrário, como ius privatum. (Alves, 2014, p. 84)

Muito embora seja relevante a discussão acerca da pertinência ou impertinência dessa classificação - o que não é objeto do presente estudo -, é oportuno reconhecer que, no âmbito dessa sistematização, o processo de codificação civilista teve por objetivo, em sua origem, dissociar-se, tanto quanto possível, de normas que fossem caracterizadas por interesses imediatos do Estado. 
Procurou-se, assim, estabelecer um certo distanciamento (ao menos normativo, e talvez não propriamente valorativo) entre a codificação civil e o desenvolvimento das cartas políticas. A esse respeito, na expressão de Paulo Luiz Netto Lôbo o Direito Civil sempre foi identificado como o "locus normativo privilegiado do indivíduo", que, contrapondo-se à constituição política, era "cogitado como a constituição do homem comum”. (Lôbo, 1999 (36), p. 99)

Paralelamente, as primeiras constituições foram norteadas pelos princípios políticos do liberalismo clássico e, dessa forma, privilegiaram a garantia das liberdades individuais, diante de um Estado mínimo, e a preservação de uma igualdade formal, no que concerne às relações entre privados. (Lôbo, 1999 (36), p. 101)

A destinação final da norma constitucional, dessa forma, volta-se para o legislador ordinário, a quem incumbiria a criação de um sistema normativo que exaurisse a regulamentação exigida no âmbito das relações privadas. (Tepedino, 2006, p. 24) Semelhante percepção havia sido apontada por Perlingieri, ao estabelecer as características da relação de eficácia entre as normas constitucionais e as normas civilistas codificadas, no âmbito do paradigma do Estado Liberal. A propósito:

As dúvidas sobre a utilização da norma constitucional por parte do intérprete derivam de uma tradição que remonta à época da revolução francesa e que atribui natureza programática à norma constitucional, relevante sob o perfil ideológico-político, mas não normativo. A norma a ser aplicada seria aquela do código, da lei especial, prevista para 'aquele' caso concreto. É o triunfo da escola da exegese. Os princípios constitucionais não representariam senão um endereço político oferecido ao legislador futuro" (Perlingieri, 2008, p. 175)

Nesse contexto, objetiva-se a estipulação de uma delimitação clara do âmbito normativo de cada um dos textos mencionados. A coerência sistêmica do Direito Civil deveria, assim, ser buscada no âmbito de seu próprio corpo normativo, qual seja, o próprio código civil.

Tal perspectiva de compreensão hermética do Direito Civil é retratada por Gustavo Tepedino - a partir de interessante classificação entre "o novo e o velho Direito Civil" - como sendo a defendida por "nostálgicos da concepção do código civil como estatuto orgânico das relações patrimoniais; os fautores da ideia de que o verdadeiro 
Direito Civil é o codificado, dogmaticamente imutável no tempo e no espaço, fundado em concepções invulneráveis, do ponto de vista estrutural e funcional, ao influxo das normas constitucionais" (Tepedino, 2006, p. 399)

A rigor, a concepção de que o Direito Civil poderia ser suficientemente regulado por um único documento, coerente e axiologicamente hermético não resistiu à força da realidade dos fatos que se impuseram. Ora, a própria crise do liberalismo clássico demonstrou a inconsistência, na prática, do projeto de se compreender a realidade por meio de raciocínios apriorísticos e distantes das relações materiais.

A propósito do tema, e muito embora refute a ideia marxista de direito como superestrutura, Pietro Perlingieri pondera que "o estudo do direito, e em particular do Direito Civil, não pode prescindir da análise da sociedade na sua historicidade local e universal". (Perlingieri, 2008, p. 170)

De fato, tal como apontado anteriormente, o advento do paradigma do Estado Social retrata o ocaso do liberalismo clássico como fonte primordial dos princípios políticos e, dessa forma, produz mudanças significativas na concepção de Estado e sua função mínima de garantia de liberdades individuais. Referido movimento, como já alertado, foi concebido no âmbito das relações econômicas e sociais tensionadas pelo desequilíbrio resultante das premissas liberais que insistiam em ignorar uma realidade dissonante com as ideias de igualdade formal então propagadas.

A realidade social, portanto, impôs uma intervenção estatal mais severa inclusive e principalmente em relações privadas - cujo âmbito de atuação extrapolaria o que havia sido regulamentado no texto do Código Civil. Surge, assim, uma produção relevante de normas, por um Estado legislador, assim descrito por Gustavo Tepedino:

O Estado legislador movimenta-se então mediante leis extracodificadas, atendendo às demandas contingentes e conjunturais, no intuito de reequilibrar o quadro social delineado pela consolidação de novas castas econômicas, que se formavam na ordem liberal e que reproduziam, em certa medida, as situações de iniquidade que, justamente, o ideário da Revolução Francesa visava a debelar. (Tepedino, 2006, p. 26)

Evidentemente que o movimento de produção legislativa se acentua na medida em que o Estado precisa prover respostas a demandas emergentes que são hauridas das - 
cada vez mais dinâmicas - relações econômicas e sociais. A necessidade de se implementar um Estado de bem-estar social exige que o legislador ordinário avance cada vez mais em searas em que a separação entre o público e o privado é, não só incerta, como inexplorada pelo sistema de codificação.

Essa tendência acaba por reduzir sensivelmente o espaço de abrangência do Código Civil, que passa a ter eficácia limitada diante do avanço da legislação excepcional. A produção legislativa especial constitui, dessa forma, um dos fundamentos do processo de descodificação das normas de Direito Civil. Semelhante tendência já havia sido notada por Perlingieri, na Itália, onde numerosas leis especiais teriam criado disciplinas próprias em relação a setores relevantes, o que teria resultado na perda da centralidade de outrora do Código Civil italiano. (Perlingieri, 2007, p. 6)

Muito embora a tendência da produção legislativa especial seja representada por uma variedade de normas, conteúdos e objetos, Gustavo Tepedino promoveu uma relevante sistematização dos principais elementos que caracterizariam essas leis especiais (Tepedino, 2006, pp. 30-33). Os elementos poderiam ser assim sintetizados:

(i) Verifica-se uma sensível alteração na técnica legislativa. São leis que definem objetivos concretos. O propósito exauriente da regulação das relações privadas é relegado a um segundo plano, em benefício de pretensões normativas específicas. Nesse sentido, v.g., são fixadas as diretrizes da política nacional do consumo; são estabelecidas as políticas públicas para proteção integral da criança e adolescente, entre outros.

(ii) Há uma alteração significativa na linguagem empregada. Considerando o objeto específico das normas especiais, o texto normativo acaba por refletir particularidades dos setores que se pretendem ver regulados, em atendimento às demandas próprias das relações em foco. A coerência textual das codificações abre espaço a aspectos técnicos e particulares, relacionados a determinado setor regulado, em benefício de uma maior adequação e eficiência.

(iii) No que concerne aos objetivos das normas, são percebidas propostas no sentido de conjugar a repressão aos atos indesejados (ou ilícitos), geralmente representada pela vedação ou pela imposição de sanções, com o incentivo a condutas almejadas pelo legislador. Tais incentivos podem ser concretizados por meio, por exemplo, de redução de impostos ou concessão de benefícios. 
(iv) O legislador especial excede os limites da disciplina das relações patrimoniais. Nesse sentido, percebe-se uma tendência a se promover uma abertura normativa a elementos relacionados à tutela da personalidade e à dignidade da pessoa humana.

(v) Por fim, nota-se o prestígio ao caráter contratual dos novos estatutos. A ideia de se promover uma regulamentação geral e abstrata, incidente indistintamente a todas as relações eventualmente subsumíveis, é acrescida de propostas no sentido de se permitir interações entre determinados grupos ou agentes (locador e locatário, fornecedores e consumidores) no sentido de preencher o conteúdo normativo da lei especial.

Por fim, deve-se destacar que o movimento de descodificação tem um efeito relevante no papel de unificação do sistema até então exercido pelo Código Civil.

Em que pese tal constatação, não se pode cogitar, evidentemente, de inúmeros estatutos, distintos entre si, e cada um regulando autônoma e independentemente as relações que, originalmente, se pretendeu normatizar. Não há uma fragmentação em diversos microordenamentos e em variados microssistemas (Perlingieri, 2007, p. 6).

Por outro lado, as relações sociais e econômicas não são estanques e classificáveis na medida da conveniência da produção legislativa. Por essa razão, se a unidade não se vislumbra no plano legislativo, nas palavras de Perlingieri, "deve ser identificado no constante e tenaz trabalho do intérprete, orientando a detectar os princípios constantes na legislação chamada especial, reconduzindo-os à unidade, mesmo do ponto de vista de sua legitimidade" (Perlingieri, 2007, p. 6)

Diante disso, o papel de unificação do sistema passa a ser exercido pelo próprio texto constitucional. Dessa forma, o âmbito de eficácia da Constituição - antes restrito às funções do Estado e ao legislador ordinário - ganha dimensão distinta, alcançado diretamente as relações concretas.

Nesse sentido, e diante de antinomias e da reconhecida impossibilidade da autossuficiência da norma codificada, o intérprete se vale das fontes inspiradas pelos princípios constitucionais para manter a unidade do sistema e alcançar respostas coerentes e com um mínimo de previsibilidade às demandas produzidas pela dinâmica das relações humanas.

O texto constitucional, portanto, excede os limites da regulamentação básica das funções do Estado, e da garantia às liberdades individuais, para situar-se no centro do 
sistema, de modo a exercer a função unificadora das normas, inclusive e principalmente, as classificadas no âmbito do ius privatum - para voltarmos à vetusta classificação do Corpus Iuris Civilis.

6.2. A constitucionalização do direito de propriedade e a experiência brasileira

Como se afirmou anteriormente, a origem do direito de propriedade no Brasil tem seus alicerces no paradigma do Estado liberal. Mais especificamente, o disposto no clássico artigo 544 do Código Napoleão exerce relevante influência até os dias atuais.

De fato, apesar das sensíveis modificações às quais foi submetido o direito de propriedade, não se deve desconsiderar, inclusive, as semelhanças na redação entre os dispositivos do mencionado artigo 544 e o que consta do Código Civil vigente, em seu artigo 1.228, assim como já explicitado anteriormente.

A influência do liberalismo clássico é percebida de forma mais contundente na Constituição Política do Império do Brasil de 25 de março de 1824, outorgada por D. Pedro I. No referido texto constitucional, nota-se, de início, que, topologicamente, o direito de propriedade está agregado aos demais direitos relacionados às liberdades e garantias civis e políticas, típicas do liberalismo clássico. Confira-se, nesse sentido, o disposto no artigo 179, inciso XXII:

Art. 179. A inviolabilidade dos Direitos Civis, e Politicos dos Cidadãos Brazileiros, que tem por base a liberdade, a segurança individual, e a propriedade, é garantida pela Constituição do Imperio, pela maneira seguinte.

(...)

XXII. E'garantido o Direito de Propriedade em toda a sua plenitude. Se o bem publico legalmente verificado exigir o uso, e emprego da Propriedade do Cidadão, será elle préviamente indemnisado do valor della. A Lei marcará os casos, em que terá logar esta unica excepção, e dará as regras para se determinar a indemnisação. 
Nota-se, da redação do artigo acima transcrito, que o direito de propriedade é marcado como uma garantia do cidadão perante o Estado. Nesse contexto, o papel do Estado volta-se à manutenção da garantia da liberdade do proprietário de usar, gozar e dispor da coisa "em toda a sua plenitude". A única exceção se refere à possibilidade do Estado de desapropriar a coisa, nos termos legalmente previstos, é com o intuito de promover o bem público. Afora isso, não se identifica, no texto constitucional, qualquer limitação à plenitude do direito de propriedade.

De fato, tal como aponta Arruda Alvim, o texto constitucional de 1824 revela a proteção do trinômio fundamental: a) liberdade; b) segurança do indivíduo e c) propriedade. (Alvim, 2014, p. 23)

A constituição republicana, de 24 de fevereiro de 1891, no que concerne ao direito de propriedade, também foi elaborada no âmbito dos princípios do liberalismo clássico. Nesse aspecto, não se verificam mudanças significativas quanto ao conteúdo do direito de propriedade. Nesse sentido, dispõe o artigo 72, §17:

Art 72 - A Constituição assegura a brasileiros e a estrangeiros residentes no País a inviolabilidade dos direitos concernentes à liberdade, à segurança individual e à propriedade, nos termos seguintes:

$\S 17$ - O direito de propriedade mantém-se em toda a sua plenitude, salva a desapropriação por necessidade ou utilidade pública, mediante indenização prévia. As minas pertencem aos proprietários do solo, salvas as limitações que forem estabelecidas por lei a bem da exploração deste ramo de indústria.

As teorias positivistas, nos termos acima explicitados, foram fundamentais para $\mathrm{o}$ estabelecimento do modelo republicano no Brasil. Pode-se afirmar que Benjamin Constant e Auguste Comte foram os precursores de uma das mais importantes correntes valorativas que nortearam a construção do conteúdo moral dos ideais republicanos durante o período de vigência da Constituição de 1981.

No que concerne especificamente ao direito de propriedade, conforme apontado anteriormente, Auguste Comte foi um dos precursores da ideia de que o direito de propriedade obriga ao cumprimento de uma determinada função que atenda a interesses 
coletivos. Ainda assim, as concepções de Comte e do positivismo em relação ao direito de propriedade não foram, textualmente, contempladas no dispositivo acima transcrito da Constituição de 1891.

É de se notar, a propósito, que, à época, apesar da predominância das concepções liberais - no âmbito das normatizações de direito privado -, há uma gradual ascensão de críticas que expunham, na prática, as contradições sociais de um liberalismo distante das relações sociais e econômicas materiais.

Nesse sentido, Otávio Luiz Rodrigues Junior, tratando do contexto de formulação do $B G B$ alemão - retratado, comumente, como um texto de inspiração liberal -, esclarece que concepções e críticas hauridas no contexto social de crise do liberalismo também foram importantes no desenvolvimento do referido código. A propósito, assevera o referido autor que:

Nesse ambiente de enorme complexidade, que se não poderia desconectar das trágicas condições sociais de milhares de seres humanos que viveram no Oitocentos, foi o BGB concebido, após 16 anos de marches et démarches. (Rodrigues Júnior, 2013, p. 70)

Como se sabe, assim como o Código Napoleão, o $B G B$ também produziu importantes reflexos no Brasil. Aliás, reputa-se, inclusive, a ele, a crítica a um suposto liberalismo anacrônico do nosso Código Civil de 1916.

Ocorre que, assim como na Europa ocidental, no Brasil também são percebidas as consequências das contradições do liberalismo clássico. Não é de todo verdadeiro afirmar que tanto o $B G B$ quanto o nosso Código Civil de 1916 passaram ao largo da realidade social e econômica que se impunha. Ora, ainda que o contexto político, social e econômico do Brasil tivesse sensíveis diferenças entre o contexto europeu, isso não significa que os efeitos da revolução industrial e suas mazelas não tenham sido, igualmente, percebidos por aqui.

Tal aspecto, aliás, é reconhecido por Gustavo Tepedino:

Esta era de estabilidade e segurança, no entanto, retratada pelo Código Civil brasileiro, entra em declínio na Europa já da segunda metade do século XIX, com reflexos na política legislativa brasileira a partir de 1920. Os movimentos sociais e o processo de industrialização crescentes do século 
XIX, aliados às vicissitudes do fornecimento de mercadorias e
à agitação popular, intensificadas pela eclosão da primeira
grande guerra, que atingiriam tão profundamente o Direito
Civil europeu, abalaram também, na sua esteira, o ordenamento
brasileiro, quando se tornou inevitável a necessidade de
intervenção estatal cada vez mais acentuada na economia. (Tepedino, 2006, pp. 25-26)

Nesse contexto, o processo de modificação do centro de gravidade do direito privado - anteriormente estabelecido nas codificações civis - foi profundamente acentuado a partir da Constituição de Weimar.

Assim como nos remete Carmen Lúcia Antunes Rocha, não se deve negar a importância do projeto do que viria a ser a Constituição mexicana de 1917, como uma primeira proposta para se estabelecer, em um texto constitucional, o aspecto da função social da propriedade da terra. (Rocha, 2004, p. 75)

Nada obstante, conforme aponta Karl Larenz, apenas com a Constituição de Weimar que se elevou a ideia de vinculação social da propriedade à categoria de princípio jurídico (Larenz, 1978, p. 79).

Do mesmo modo, esclarece Konrad Hesse que, em Weimar, ocorreram importantes modificações na relação entre direito constitucional e direito privado. (Hesse, 1995, p. 47). De fato, na Constituição do Reich, de 1871, a propriedade estava garantida (art. 153.1). No entanto, a garantia da propriedade tinha funções de preservação e proteção de tal direito fundamental. Nesse contexto, a garantia tinha, como ponto central de sua eficácia, evitar a sua pura e simples abolição, em face de eventuais radicalismos revolucionários (Hesse, 1995, pp. 49-50). A Constituição de Weimar, por outro lado, ultrapassando o paradigma do Estado liberal, acentuou as obrigações relativas à necessidade de intervenção estatal para garantir direitos relacionados ao bem-estar social.

A propósito do tema, Gregory S. Alexander faz alusão à existência de uma tensão, no constitucionalismo alemão, em relação ao sistema de valores do Estado social e ao sistema de direitos relacionados à ideia de rule of law. Trata-se, segundo o referido autor, de uma constante tensão entre o Rechsstaat e o Sozialstaat (Alexander, 2006, p. 150). O primeiro seria caracterizado pela rejeição do poder absoluto, garantia e proteção da liberdade política pessoal, separação de poderes, supremacia da Constituição, incluindo revisão judicial (judicial review) e limitação e controle judicial da autoridade 
governamental. O segundo, por sua vez, reflete um esforço no sentido de contrabalançar as injustiças socioeconômicas que resultam do liberalismo clássico, providenciando uma legitimidade normativa para a limitação de direitos individuais, incluindo o direito de propriedade. (Alexander, 2006, pp. 151-153)

Muito embora já fosse possível verificar, anteriormente, na Alemanha de Biskmarck, uma notável ascensão de pretensões políticas e jurídicas relacionadas a direitos sociais, a Constituição de Weimar foi um marco no sentido de aprofundamento das ideias relacionadas ao Sozialstaat. (Alexander, 2006, pp. 153-154)

No que concerne especificamente ao direito de propriedade, com a redação do art. 153, II, do referido texto constitucional, estabelece-se o princípio de que a propriedade obriga. A propriedade deixa de ser apenas um direito individual do proprietário, que não poderia ser suprimido pelo Estado, e passa a se relacionar a um dever de observar a destinação de seu domínio vinculada a um determinado interesse coletivo.

Se, na Alemanha, a Constituição de Weimar consolidou a guinada para o paradigma do Estado Social; no Brasil, a Constituição de 1934 foi a responsável pelo texto que marcou o advento do Estado social brasileiro. Nesse exato sentido apontam Paulo Bonavides e Paes de Andrade:

A Constituição de 16 de julho de 1934 funda juridicamente no País uma forma de Estado social que a Alemanha estabelecera com Bismarck há mais de um século, aperfeiçoara com Preuss (Weimar) e finalmente iria proclamar com solenidade textual em dois artigos da Lei Fundamental de Bonn, de 1949, cunhando a célebre fórmula do chamado Estado social de direito, matéria de tanta controvérsia nas regiões da doutrina, da jurisprudência e da aplicação hermenêutica. (Bonavides \& Andrade, 1991, p. 325)

O contexto de ascensão dos direitos sociais, portanto, exerceu relevante influência na Assembleia Constituinte de 1933. Como se sabe, a Constituição de 1934 é resultante do movimento de 1930, do Governo Provisório, à época, e da Revolução Constitucionalista de 1932. No dizer de Paulo Bonavides e Paes de Andrade, "as preocupações sociais ganham preeminência; já não têm o caráter de 'questão de polícia' que marcou esse tema na República Velha”. (Bonavides \& Andrade, 1991, p. 319) 
O texto constitucional de 1934 é fortemente marcado por contradições em seus próprios termos. De um lado, verifica-se uma relevante herança dos princípios do liberalismo que inspiraram a Constituição de 1981; de outro, uma tendência crescente de intervencionismo estatal norteado por uma tentativa de resposta às inúmeras preocupações de natureza econômico-social.

A ditadura do Governo Provisório decorreu de um movimento político e militar que teve entre suas pretensões a consideração dos interesses da classe média e da classe obreira. Esse viés social, no entanto, não teve o efeito de suprimir a principiologia liberal do texto constitucional anterior. Na prática, ocorreu uma justaposição hegemônica de valores, sem uma respectiva supressão de direitos e garantias individuais contidas no texto da República Velha (Bonavides \& Andrade, 1991, p. 321)

Quanto ao direito de propriedade, muito embora o texto da Constituição de 1934 não houvesse feito menção ao aspecto da função social da propriedade - conforme bem observa Gustavo Tepedino (Tepedino \& Schreiber, 2002, p. 118) -, houve uma sensível evolução em relação à pretensão de observância de direitos sociais relacionados a tal direito. Antes de comentá-lo, oportuno se faz destacar o teor do texto do artigo 131 da Constituição de 1934:

Art 113 - A Constituição assegura a brasileiros e a estrangeiros residentes no País a inviolabilidade dos direitos concernentes à liberdade, à subsistência, à segurança individual e à propriedade, nos termos seguintes:

17) É garantido o direito de propriedade, que não poderá ser exercido contra o interesse social ou coletivo, na forma que a lei determinar. A desapropriação por necessidade ou utilidade pública far-se-á nos termos da lei, mediante prévia e justa indenização. Em caso de perigo iminente, como guerra ou comoção intestina, poderão as autoridades competentes usar da propriedade particular até onde o bem público o exija, ressalvado o direito à indenização ulterior.

Nota-se, inicialmente, que o artigo 113 assegura a inviolabilidade do direito de propriedade, tal como preconizam os princípios do liberalismo clássico. Logo em seguida, 
no entanto, coteja-o com um - igualmente inviolável - direito à subsistência. Ambos os direitos, de propriedade e de subsistência, em tese, estão inseridos em um mesmo patamar de igualdade, devendo ser conformados de modo a se evitar, evidentemente, que a aplicação de um obstaculize a eficácia do outro.

Referido aspecto, por si só, rompe com as pretensões absolutistas do direito de propriedade herdadas do clássico dispositivo do Código Napoleão. Como visto acima, a Constituição da República Velha procurou assegurar o exercício de direito de propriedade em sua "plenitude" - muito embora estabelecesse a possibilidade de desapropriação.

No novo texto, não só a expressão "plenitude" é retirada, como o interesse social ou coletivo passam a figurar como limitadores do exercício do direito de propriedade. Esta, portanto, não apenas deixa de ser absoluta, como interesses de natureza social, inclusive distintos daqueles do proprietário, poderão, por força do próprio texto constitucional, lhe impor limitações. Trata-se, assim, de profunda evolução em relação ao texto constitucional anterior.

Como afirmado anteriormente, ainda que o texto constitucional de 1934 não fizesse referência à função social da propriedade como princípio a ser observado, os três fatores acima referidos - sem desconsiderar o sistema como um todo e seu novo vetor ideológico - demonstram claramente uma mudança, na direção do paradigma do Estado social, no regramento constitucional do direito de propriedade. Como visto, tais fatores seriam, notadamente: (i) previsão da inviolabilidade do direito à subsistência; (ii) a supressão do caráter absoluto da propriedade e (iii) a expressa previsão dos interesses coletivos e sociais como vetores de limitação do direito. ${ }^{6}$

Em 10 de novembro de 1937, o Presidente Getúlio Vargas houve por bem outorgar a Carta de 1937, de autoria do Ministro da Justiça Francisco Campos. Como é de conhecimento comum, a Carta de 37 surgiu em um contexto de escalada do autoritarismo nos primórdios do que viria a ser a Segunda Grande Guerra Mundial.

A inspiração ao seu texto remonta à Constituição da Polônia, razão pela qual ganhou, pejorativamente, a alcunha de "A Polaca". Nada obstante, não se deve desconsiderar a forte influência dos regimes autoritários do fascismo de Mussolini, vitorioso na Itália, em 1922, e do nazismo de Hitler, na Alemanha. Em um período

${ }^{6}$ A propósito do referido dispositivo e a sua importância histórica no constitucionalismo brasileiro, Carmen Lúcia tece os seguintes comentários: "Foi, portanto, a Constituição de 1934 a primeira e marcante fonte do direito de propriedade-função social, que não mais se pôde desconhecer no constitucionalismo e nas normas infraconstitucionais, que pelos princípios fundamentais se informam." (Rocha, 2004, p. 81) 
conturbado, de desenvolvimento industrial e de agitações sociais, a ameaça do comunismo serviu de justificativa para a outorga da Carta de 1937. (Bonavides \& Andrade, 1991, p. 340)

O autoritarismo que marcou o texto constitucional em questão foi refletido na disciplina do direito de propriedade. Se na Constituição anterior, conforme acima explicitado, verificou-se a presença de influências da doutrina do Estado social, a Carta de 1937 parece ter retroagido em relação à caracterização da função social da propriedade, apesar dos inúmeros mecanismos de intervenção do Estado nas relações particulares, sociais e econômicas.

A propósito, a previsão constitucional do direito de propriedade restou assim consignada:

Art 122 - A Constituição assegura aos brasileiros e estrangeiros residentes no País o direito à liberdade, à segurança individual e à propriedade, nos termos seguintes:

14) o direito de propriedade, salvo a desapropriação por necessidade ou utilidade pública, mediante indenização prévia. O seu conteúdo e os seus limites serão os definidos nas leis que lhe regularem o exercício.

O item 14 foi suspenso, posteriormente, pelo Decreto $\mathrm{n}^{\mathrm{o}} 10.358$, de 1942, com o objetivo de se instituir maior discricionariedade ao Estado para intervir no direito de propriedade particular.

Pela redação do referido dispositivo, nota-se a supressão da possibilidade de limitação do direito de propriedade para atender interesses sociais ou coletivos. Da mesma forma, verifica-se a exclusão do direito de subsistência como uma garantia individual. Diferentemente, esse direito foi especificado no capítulo referente à "família"7 e, principalmente, no capítulo que trata da "Ordem Econômica", ao restar especificado como um objetivo a ser alcançado mediante o trabalho. ${ }^{8}$

7 “Art. 127. (...)

Aos pais miseráveis assiste o direito de invocar o auxílio e proteção do Estado para a subsistência e educação da sua prole."

8 "Art 136 - O trabalho é um dever social. O trabalho intelectual, técnico e manual tem direito a proteção e solicitude especiais do Estado. A todos é garantido o direito de subsistir mediante o seu trabalho honesto e este, como meio de subsistência do indivíduo, constitui um bem que é dever do Estado proteger, assegurando-lhe condições favoráveis e meios de defesa." 
É possível verificar, portanto, um certo distanciamento das ideias que fundamentaram a perspectiva de que o direito de propriedade estaria relacionado a uma função social a ser cumprida pelo proprietário, individualmente. Em contrapartida, o autoritarismo, o intervencionismo estatal e o trabalhismo da era Vargas preencheram os espaços relativos à regulamentação constitucional do tema na Carta de 1937.

O ocaso do autoritarismo que marcou o Estado Novo resultou na instalação de uma nova assembleia constituinte em 1946. Pela primeira vez, em nossa história constitucional, a assembleia foi composta por integrantes do Partido Comunista Brasileiro, então saído recentemente da clandestinidade. Nada obstante, pode-se afirmar que a assembleia constituinte era marcada por uma maioria de conservadores com tendências liberais e que faziam concessões ao proletariado, como forma de dar uma resposta aos conflitos exteriorizados nas lutas de classes. (Bonavides \& Andrade, 1991, p. 390).

Diante dessa composição, houve uma consolidação da tradição liberal da experiência constitucional brasileira, sem, contudo, deixar-se de se contemplar os avanços advindos a partir do Estado social. Por tais razões, assevera Paulo Bonavides que “a Constituição de 1946 assegurava, pois um Estado social de direito vazado na mais ampla tradição liberal dos juristas brasileiros”. (Bonavides \& Andrade, 1991, p. 412)

Verifica-se, assim, uma clara tentativa de conciliação entre os preceitos de um Estado liberal com os avanços que os ideais de Estado social que foram, inicialmente, desenvolvidos no texto de 1937.

Nesse contexto, a Constituição de 1946 incrementou a garantia individual do proprietário em relação à intervenção estatal no direito de propriedade. O artigo 141, § 16, assim, garante o direito de propriedade e prevê, de forma inovadora, nas hipóteses de desapropriação, a necessidade de pagamento de indenização justa, prévia e em dinheiro.

De outro lado, o referido texto constitucional inaugurou, na história constitucional brasileira, o princípio da função social da propriedade, em seu artigo 147, que foi assim redigido:

Art 147 - O uso da propriedade será condicionado ao bem-estar social. A lei poderá, com observância do disposto no art. $141, \S 16$, promover a justa distribuição da propriedade, com igual oportunidade para todos. 
Nota-se, da leitura do artigo 147, uma certa semelhança com o dispositivo que constou da Constituição de Weimar, acima mencionado. Ainda que tardiamente, no entanto, os princípios que a inspiraram foram refletidos no texto constitucional brasileiro.

A Constituição de 1946 teve sua vigência, como se sabe, interrompida pela ditadura militar, iniciada em 1964. A tentativa de legitimação pretensamente fundada em um Estado de Direito foi consubstanciada na Carta outorgada de 1967, classificada por Gustavo Capanema como a "Carta Super-polaca", em referência à de 37 (Bonavides \& Andrade, 1991, p. 431). A propósito da constituinte que a elaborou, esclarecedores são os comentários de Paulo Bonavides:

Não houve propriamente uma tarefa constituinte, mas uma farsa constituinte.

Isso porque os parlamentares, além de não estarem investidos de faculdades constituintes, estavam também cerceados pelos atos institucionais.

A coação ao trabalho dos parlamentares exercida pelos atos excepcionais impediu que os representantes do povo, mesmo sem os poderes constituintes autorizados pelo eleitorado, pudessem fazer uma Carta constitucional relativamente independente. (Bonavides \& Andrade, 1991, pp. 432-433)

Conspurcada pelo autoritarismo, a Constituição de 1967 foi mais uma tentativa de se legitimar juridicamente um regime antidemocrático por um texto constitucional que, efetivamente, não representou, sequer, os interesses e valores de um arremedo de assembleia constituinte censurada pela espada do militarismo.

O artigo 150 da Constituição de 1967 manteve a propriedade como um direito individual. O artigo 157, por sua vez, elevou o princípio da função social da propriedade à categoria de princípio da ordem econômica e social:

Art 157 - A ordem econômica tem por fim realizar a justiça social, com base nos seguintes princípios:

I - liberdade de iniciativa; 
II - valorização do trabalho como condição da dignidade humana;

III - função social da propriedade;

IV - harmonia e solidariedade entre os fatores de produção;

V - desenvolvimento econômico;

VI - repressão ao abuso do poder econômico, caracterizado pelo domínio dos mercados, a eliminação da concorrência e o aumento arbitrário dos lucros.

Verifica-se, portanto, que, apesar de o texto constitucional de 1967 ter se afastado politicamente dos ideais democráticos que nortearam a Constituição de 1946, em razão do golpe militar de 1964 - ao qual se objetivava a legitimação política e jurídica -, no que concerne ao direito de propriedade, a Carta de 67 não retrocedeu, seja na garantia ao indivíduo quanto aos direitos de proprietário, seja na compreensão da propriedade a partir de seu aspecto funcional em relação aos interesses sociais.

Isso não significa, todavia, que a redação do dispositivo acima transcrito evitou que fossem cometidos os mais diversos e absurdos desrespeitos aos direitos e garantias individuais, por parte do Estado, com fundamento nas políticas repressivas do regime militar. Por mais que o artigo 150 dispusesse sobre a inviolabilidade dos direitos concernentes à vida, à liberdade, à segurança e à propriedade, nunca, na história do país, tantos excessos e violações a tais direitos foram praticados pelo Estado.

A partir de 1984, com a intensificação dos movimentos da sociedade civil contra a ditadura militar, o regime acentuou o processo de transição para um sistema democrático. Nesse ano, o então Presidente General João Figueiredo anunciou, pela televisão, uma emenda constitucional prevendo eleições diretas para o ano de 1988.

Logo em seguida, em janeiro de 1985, o Colégio Eleitoral elegeu Tancredo Neves como o novo Presidente da República. Em virtude de problemas de saúde, Tancredo Neves não chegou a assumir. Muito embora houvesse uma expectativa de que o então chefe do Legislativo, Ulysses Guimarães, assumisse a Presidência, um acordo com a efetiva atuação dos militares resultou na posse de José Sarney, quem, efetivamente, foi o responsável pela convocação da Assembleia Constituinte em 1987. 
Como bem observam Paulo Bonavides e Paes de Andrade, a Assembleia Constituinte de 1987 parece não ter um perfil ideológico claramente definido. Há, de fato, grupos corporativistas muito bem organizados que incutiram, no texto constitucional, as suas pretensões. ${ }^{9}$

Houve, no entanto, alguns debates em torno de temas específicos (como, v.g., temas sociais, direitos dos trabalhadores; questões da terra, propriedade e reforma agrária; capital estrangeiro, etc.) nos quais se pôde verificar duas tendências. De fato, apesar de uma posição majoritariamente conservadora, a Constituinte propiciou, nos temas em questão, alguma representatividade de grupos e interesses específicos. Nesse sentido, pode-se verificar uma relativa representação da sociedade, no dizer de Paulo Bonavides e Paes de Andrade, "com todas as suas intranquilidades, preocupações, instabilidade e deficiências de formação e de prática política”. (Bonavides \& Andrade, 1991, p. 474)

A propósito do tema, o famoso discurso de Afonso Arinos de Melo Franco, presidente da Comissão de Sistematização, proferido na sessão magna de promulgação da Constituição de 1988, em 5.10.1988, é bem representativo dos anseios que verificavam à época em relação à garantia dos direitos individuais vis-à-vis a proteção dos direitos sociais:

É importante insistir neste ponto. A garantia dos direitos individuais é cada vez mais eficaz e operativa nas Constituições contemporâneas, mas a garantia dos direitos coletivos e sociais, fortemente capitulada nos textos, sobretudo nos países em desenvolvimento e, particularmente, nas condições do Brasil, torna-se extremamente duvidosa (para usarmos uma expressão branda), quaisquer que sejam as afirmações gráficas existentes nos documentos, como este que estamos, hoje, comemorando. Afirmar o contrário é ingenuidade, ilusão, ou falta de sinceridade, quem sabe de coragem. Direito individual assegurado, direito social sem garantia - eis a situação. (Franco, 2016)

9 Nesse sentido, esclarecem os referidos autores: "a ação partidária foi substituída pela movimentação dos grupos e a imprensa acusou a organização de lobbies de interesses os mais variados (o lobby santo, da Igreja Católica; o lobby evangélico, das várias ramificações protestantes; o lobby dos prefeitos, dos governadores, das multinacionais, das mulheres, dos cartorários, dos servidores públicos, etc.), como influenciadores ou deformadores da vontade da Constituinte" (Bonavides \& Andrade, 1991, p. 472) 
O excerto acima transcrito bem demonstra uma preocupação da Assembleia Constituinte em relação à efetivação dos interesses de natureza social. Não se pode negar que o texto constitucional contenha um expressivo rol de direitos e garantias relacionados a tais interesses. Ainda assim, todavia, preocupou-se o constituinte em se atribuir eficácia aos referidos direitos, além, evidentemente, das "afirmações gráficas existentes nos documentos", para utilizarmos a expressão eternizada no discurso em apreço.

Essa preocupação em reforçar direitos e garantias relacionadas a interesses sociais restou, de fato, explicitada no texto constitucional. Em um olhar retrospectivo (não tão distante, assim, diga-se de passagem), é possível verificar que houve, efetivamente, avanços importantes nessa direção, notadamente no que concerne ao direito de propriedade.

Tais avanços se deram, principalmente, pela permeabilidade do Congresso em relação à participação de grupos que representaram diferentes interesses em relação ao tema em apreço. Trabalhadores rurais e os então futuros articuladores do movimento dos sem-terra pressionaram os constituintes para que seus pleitos fossem contemplados. Concomitantemente, o denominado Centrão, de perfil conservador, em conjunto com a União Democrática Ruralista - UDR, também influenciaram sensivelmente a elaboração da Carta de 1988. (Rocha, 2004, p. 86)

Nesse contexto, a Assembleia Constituinte de 1988 reforça a propriedade como um direito fundamental individual, sem, todavia, deixar de ressaltar que a propriedade exercerá a sua função social:

Art. $5^{\circ}$ Todos são iguais perante a lei, sem distinção de qualquer natureza, garantindo-se aos brasileiros e aos estrangeiros residentes no País a inviolabilidade do direito à vida, à liberdade, à igualdade, à segurança e à propriedade, nos termos seguintes:

$$
\begin{aligned}
& \text { (...) } \\
& \text { XXII - é garantido o direito de propriedade; } \\
& \text { XXIII - a propriedade atenderá a sua função social; }
\end{aligned}
$$

É de se notar que o direito de propriedade, como direito fundamental, vem, topologicamente, no caput do artigo $5^{\circ}$, relacionado ao princípio da igualdade e da 
liberdade. Trata-se, pois, de uma expressa referência aos fundamentos liberais do direito de propriedade, tal como os foram delineados notadamente por Locke e Kant, nos termos em que se demonstrou anteriormente.

Por mais que, atualmente (por boa parte da doutrina), sejam enfatizados os avanços em relação à função social da propriedade - por razões justificáveis -, não se deve desconsiderar os expressos fundamentos liberais insculpidos no texto constitucional brasileiro como conformadores do direito de propriedade.

Nesse sentido, a interpretação constitucional que desconsidera, no direito brasileiro, o direito de propriedade como decorrência direta dos anseios do homem relacionados aos princípios da igualdade e da liberdade é dissociada do que restou consolidado pela Assembleia Constituinte e do próprio texto da Constituição.

A título de exemplificação, menciona-se, nessa linha de raciocínio, o posicionamento de Carmen Lúcia Antunes Rocha, para quem "somente a propriedadefunção social é, pois, objeto do direito constitucionalmente garantido nos termos do disposto no capítulo dos direitos fundamentais" (Rocha, 2004, p. 88).

Ousamos, muito respeitosamente, discordar.

De fato, não há, pelo texto constitucional, como persistir o direito de propriedade em contrariedade com a função social (observando-se, evidentemente, processos democráticos, para se extrair o conteúdo de tal preceito), de modo a prevalecer o interesse individual ao custo da eliminação das pretensões sociais. Isso não significa, todavia, que o direito de propriedade terá, por força do texto constitucional, como o seu único norte de conformação o interesse coletivo.

A função social da propriedade não derroga a proteção dos interesses individuais, assim como não elimina a liberdade individual relacionada à utilização da propriedade particular como forma de alcance de pretensões autonomamente escolhidas pelo titular do domínio. Assim, a garantia do direito individual de propriedade, pelo próprio texto constitucional de 1988, é autônoma em relação à função social, muito embora o conteúdo do referido direito seja correlato e interdependente em relação à proteção dos interesses coletivos eventualmente afetados pelo uso da propriedade.

Não se diga, igualmente, que a função social da propriedade poderia ser confundida, em algumas situações, com o interesse da coletividade de manter preservado o interesse individual relacionado à liberdade e autodeterminação, visto que tratar-se-ia de valores coletivamente compartilhados. Tal falácia, claramente, mascara não só as diferenças nos contextos históricos e sociais nos quais foram cunhados os paradigmas de 
Estado, mas também, principalmente, as divergências fundamentais dos critérios éticovalorativos que nortearam a criação dos diferentes princípios em questão.

Ora, como se demonstrou acima, o Constituinte de 1988 esforçou-se para contemplar no texto constitucional os pleitos dos diversos componentes dos tecidos sociais que compõem a sociedade brasileira. Eis, portanto, a razão pela qual tanta dificuldade há para se estabelecer um perfil ideológico da Carta de 1988. Dessa forma, se a própria Assembleia Constituinte não foi capaz de fazer prevalecer um determinado sistema valorativo, que legitimidade teria o intérprete para fazê-lo?

Evidencia-se, portanto, a necessidade de realizar a devida ponderação dos princípios incidentes sobre o direito de propriedade para que seja possível a realização de sua conformação com o texto constitucional. Nesse sentido, há que se reconhecer uma tensão não só no âmbito dos interesses relacionados à dicotomia público/privado, mas, igualmente, evolvendo diversificado feixe de pretensões relacionadas ao uso e disposição da propriedade privada. A partir dessa compreensão é que o devido sopesamento dos valores e interesses se faz necessário, de modo a se obter, em situações mais específicas, o conteúdo constitucional do direito de propriedade.

Como o reconhece Gilmar Mendes, tal tarefa - de complexa concretização - é própria da aplicação, ao caso concreto, de direitos fundamentais. Assim sendo, a ponderação deverá ser realizada de modo a se preservar o núcleo essencial ${ }^{10}$ dos direitos envolvidos, evitando-se, dessa forma, a integral supressão de algum dos valores fundamentais garantidos constitucionalmente:

Essa necessidade de ponderação entre o interesse individual e o interesse da comunidade é, todavia, comum a todos os direitos fundamentais, não sendo uma especificidade do direito de propriedade.

A afirmação sobre a legitimidade ou a ilegitimidade de determinada alteração no regime de propriedade há de decorrer, pois, de uma cuidadosa ponderação sobre os bens e valores em questão.

\footnotetext{
${ }^{10}$ Não por outra razão, Gilmar Ferreira Mendes assevera que "O exercício dos direitos individuais pode dar ensejo, muitas vezes, a uma série de conflitos com outros direitos constitucionalmente protegidos. Daí fazer- se mister a definição do âmbito ou núcleo de proteção e, se for o caso, a fixação precisa das restrições ou das limitações a esses direitos (limitações ou restrições = Schranke oder Eingriff)" (Mendes, 2012, p. 33)
} 


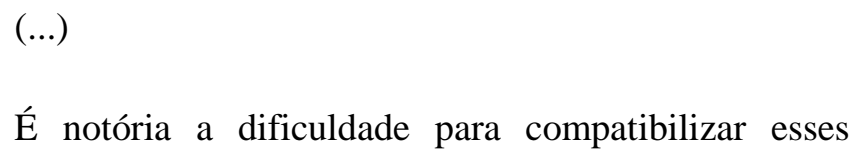
valores e interesses diferenciados. Daí enfatizar-se que o poder de conformação do legislador é tanto menor quanto maior for o significado da propriedade como elemento de preservação da liberdade individual. Ao contrário, a faculdade do legislador para definir o conteúdo e impor restrições ao direito de propriedade há de ser tanto mais ampla quanto mais intensa for a inserção do objeto do direito de propriedade no contexto social.” (BVerfGE 50, 290 (340))

Vê-se, pois, que o legislador "dispõe de uma relativa liberdade na definição do conteúdo da propriedade e na imposição de restrições. Ele deve preservar, porém, o núcleo essencial do direito de propriedade, constituído pela utilidade privada e, fundamentalmente, pelo poder de disposição. A vinculação social da propriedade, que legitima a imposição de restrições, não pode ir ao ponto de colocá-la, única e exclusivamente, a serviço do Estado ou da comunidade. (Mendes, 2010, pp. 100-101)

A dicotomia entre interesses individuais e pretensões sociais também aparece insculpida no artigo 170 da Constituição Federal:

Art. 170. A ordem econômica, fundada na valorização do trabalho humano e na livre iniciativa, tem por fim assegurar a todos existência digna, conforme os ditames da justiça social, observados os seguintes princípios:

$$
\begin{aligned}
& \text { I - soberania nacional; } \\
& \text { II - propriedade privada; } \\
& \text { III - função social da propriedade; } \\
& \text { IV - livre concorrência; } \\
& \text { V - defesa do consumidor; }
\end{aligned}
$$


VI - defesa do meio ambiente, inclusive mediante tratamento diferenciado conforme o impacto ambiental dos produtos e serviços e de seus processos de elaboração e prestação; (Redação dada pela Emenda Constitucional n ${ }^{\circ} 42$, de 19.12.2003)

VII - redução das desigualdades regionais e sociais;

VIII - busca do pleno emprego;

IX - tratamento favorecido para as empresas de pequeno porte constituídas sob as leis brasileiras e que tenham sua sede e administração no País. (Redação dada pela Emenda Constitucional $n^{\circ} 6$, de 1995)

Parágrafo único. É assegurado a todos o livre exercício de qualquer atividade econômica, independentemente de autorização de órgãos públicos, salvo nos casos previstos em lei.

Cabe mencionar, ainda, o tratamento especial dado pelo texto constitucional em relação à propriedade rural. Evidencia-se uma preocupação específica do constituinte com o emprego da propriedade segundo a sua destinação social. Objetivou-se, dessa forma, mitigar a titularização da propriedade privada com propósitos puramente especulativos, em benefício da utilização da terra para fins de produção, geração de riqueza e incremento de empregos no campo. Trata-se, como visto acima, de reflexos diretos das pressões exercidas por grupos que defendiam interesses dos pequenos produtores rurais, dos trabalhadores do campo e dos que viriam a compor, posteriormente, o movimento dos trabalhadores sem-terra.

Quanto ao tópico específico, o texto constitucional procurou, tanto quanto possível no âmbito de uma Constituição, especificar diretrizes para o alcance, no caso concreto, do conteúdo da função social da propriedade. Assim foi feito, exatamente, com o intuito de se estabelecer os critérios que seriam empregados no caso de desapropriação - por descumprimento da função social - para fins de reforma agrária. A propósito:

Art. 184. Compete à União desapropriar por interesse social, para fins de reforma agrária, o imóvel rural que não esteja cumprindo sua função social, mediante prévia e justa 
indenização em títulos da dívida agrária, com cláusula de preservação do valor real, resgatáveis no prazo de até vinte anos, a partir do segundo ano de sua emissão, e cuja utilização será definida em lei.

Art. 186. A função social é cumprida quando a propriedade rural atende, simultaneamente, segundo critérios e graus de exigência estabelecidos em lei, aos seguintes requisitos:

I - aproveitamento racional e adequado;

II - utilização adequada dos recursos naturais disponíveis e preservação do meio ambiente;

III - observância das disposições que regulam as relações de trabalho;

IV - exploração que favoreça o bem-estar dos proprietários e dos trabalhadores.

Relevante mencionar, por fim, o endereçamento da questão da função social da propriedade urbana, realizado pelo constituinte, para o âmbito do ordenamento constante do plano diretor:

Art. 182. A política de desenvolvimento urbano, executada pelo Poder Público municipal, conforme diretrizes gerais fixadas em lei, tem por objetivo ordenar o pleno desenvolvimento das funções sociais da cidade e garantir o bem- estar de seus habitantes. (Regulamento) (Vide Lei $\mathrm{n}^{\mathrm{o}}$ 13.311, de 11 de julho de 2016)

$\S 1^{\circ} \mathrm{O}$ plano diretor, aprovado pela Câmara Municipal, obrigatório para cidades com mais de vinte mil habitantes, é o instrumento básico da política de desenvolvimento e de expansão urbana. 
$\S 2^{\circ}$ A propriedade urbana cumpre sua função social quando atende às exigências fundamentais de ordenação da cidade expressas no plano diretor.

$\S 3^{\circ}$ As desapropriações de imóveis urbanos serão feitas com prévia e justa indenização em dinheiro.

$\S 4^{\circ}$ É facultado ao Poder Público municipal, mediante lei específica para área incluída no plano diretor, exigir, nos termos da lei federal, do proprietário do solo urbano não edificado, subutilizado ou não utilizado, que promova seu adequado aproveitamento, sob pena, sucessivamente, de:

I - parcelamento ou edificação compulsórios;

II - imposto sobre a propriedade predial e territorial urbana progressivo no tempo;

III - desapropriação com pagamento mediante títulos da dívida pública de emissão previamente aprovada pelo Senado Federal, com prazo de resgate de até dez anos, em parcelas anuais, iguais e sucessivas, assegurados o valor real da indenização e os juros legais.

Nesse aspecto, andou bem o constituinte ao delegar à municipalidade a tarefa de concretizar normativamente os aspectos específicos relacionados à função social da propriedade. De fato, em se tratando de um país de dimensões continentais, com inúmeras e complexas especificidades econômicas, sociais e territoriais, nada mais razoável do que se atribuir ao legislador local o dever de, diante das circunstâncias próprias do contexto urbano vivenciado, reconhecer e contemplar os interesses envolvidos.

A missão do legislador local, evidentemente, não está absolutamente livre e autônoma em relação à cogência dos princípios constitucionais envolvidos. O exercício do poder legislativo deverá ser exercido em observância dos direitos fundamentais constitucionalmente assegurados, sob pena, inclusive, de censura direta a ser exercida pelo Poder Judiciário. 
6.3. A constitucionalização do direito de propriedade e a questão da eficácia dos direitos fundamentais

A constitucionalização do direito de propriedade, nos termos explicitados anteriormente, transferiu o centro do sistema normativo do Código Civil para o texto constitucional. Assim, a Constituição torna-se a referência do sistema para a conformação e determinação de restrições relativas ao direito de propriedade. Apenas pelo texto constitucional que se mantém a coesão e a coerência de todo o arcabouço jurídico/normativo que regula o tema.

Nesse contexto, é de se indagar, todavia, o que significaria considerar a proteção e a garantia constitucional do direito de propriedade como um direito fundamental. No que consistira e de que modo poderia ser apreendido o âmbito de proteção do direito fundamental à propriedade?

Como bem aponta Gilmar Mendes, no que concerne aos direitos individuais, a identificação do âmbito de proteção constitucional de direitos fundamentais não pode ser obtida, tão somente, pela interpretação e aplicação de regras gerais previstas no texto. Exige-se, muito além disso, para cada direito fundamental, um determinado procedimento (Mendes, 2012, p. 35). Acrescentaríamos que o procedimento legítimo para apreensão do âmbito de proteção do direito fundamental de propriedade seria aquele norteado pelos princípios democráticos. Tanto quanto a conformação e a restrição de tal direito se dissociarem dos critérios democráticos para obtenção de concretude normativa esvaziarse-á a legitimidade da solução jurídica alcançada. O estabelecimento de uma solução, entre as várias que uma regra geral interpretada autonomamente permite, sem a devida observância do procedimento democrático, se revelará autoritário, por mais coerente que possa ser a fundamentação hermenêutica.

O direito de propriedade, tal como previsto em nosso texto constitucional, é referido não só pelo seu aspecto de garantia, mas, igualmente, pela necessidade de observância de possíveis restrições. O tratamento constitucional, todavia, não é (e nem poderia sê-lo) exauriente. Nesse sentido, confia-se ao legislador ordinário a incumbência, não raras vezes, de definir o próprio conteúdo do direito de propriedade. Há, em tal mister, um duplo objetivo, qual seja, o estabelecimento da conformação do direito, em consonância com o norte principiológico estabelecido constitucionalmente, e a imposição das respectivas restrições. (Mendes, 2012, p. 38) 
Há que se destacar, a esse respeito, a discussão relativa à possibilidade lógica de ser impor restrições a direitos individuais fundamentais ou não. Essa discussão, conforme esclarece Gilmar Mendes, é norteada por duas teorias principais. A externa admite a existência autônoma do direito e de respectiva restrição. O direito existe e tem seu conteúdo constituído independentemente das restrições a serem impostas, em razão de eventuais interesses coletivos a serem contemplados. Diferentemente, para os adeptos da teoria interna, não haveria que se falar em direito e restrições a serem contrapostos. Essa teoria defende que o próprio conteúdo do direito individual é que estabeleceria seus próprios limites. Nesse sentido, não haveria um fator externo a restringir o direito. (Mendes, 2012, p. 40)

Nada obstante, para o mencionado autor, os direitos fundamentais deverão ser concebidos, primordialmente, como princípios.

Como tais, os direitos individuais, ainda que submetidos a restrições legais (por força de reserva legal simples ou qualificada) não devem ser limitados ou restringidos de modo a se esvair o seu núcleo essencial.

A proteção a esse núcleo pode se referir a um determinado conteúdo material absoluto, que estaria a salvo de qualquer ação legislativa e de qualquer intervenção estatal (teoria absoluta). Diferentemente, tal proteção poderia estar relacionada à identificação, no caso concreto, tendo em vista o objetivo perseguido pela norma restritiva (teoria relativa). Para esta última teoria, faz-se necessária a realização de um procedimento de ponderação, com fundamento no princípio da proporcionalidade, entre meios e fins. $\mathrm{O}$ núcleo essencial, assim, seria aquele conteúdo, identificável no caso concreto, que deveria ser preservado, após a realização de procedimento de ponderação.

Há, ainda, a teoria conciliadora proposta por Hesse que estipula o princípio da proporcionalidade como meio mais adequado para evitar que um determinado direito fundamental seja suprimido de forma contrária à Constituição (Mendes, 2012, p. 60). Nesse caso, no entanto, não se trata de uma ponderação de natureza utilitarista entre meios e fins, mas, sim, da aplicação do princípio da proporcionalidade na ponderação de princípios em colisão.

No que concerne ao direito de propriedade, há, tanto na doutrina como na jurisprudência, muita confusão acerca do que seria o conteúdo do direito de propriedade, a partir de sua conformação ou concretização, e o que seria, efetivamente, uma limitação a tal direito, segundo a ideia genérica de função social da propriedade. 
De fato, a vetusta dicotomia interesse público/interesse privado e a pretensão liberalista clássica de se alcançar o status absoluto do direito de propriedade vis-à-vis os anseios sociais do final do século XIX induzem à conclusão de que tudo aquilo que visa mitigar e restringir o puro arbítrio individual de uso, gozo, fruição e disposição do objeto de domínio, constituiria uma restrição, pura e simples, de um direito pretensamente absoluto.

A bem da verdade, o direito de propriedade não possui um caráter estático, claramente definido e apreendido universalmente por critérios específicos e bem delimitados. Não o é, hodiernamente, e também nunca o foi. De fato, o direito de propriedade sempre esteve vinculado a concepções valorativas e a contextos socioeconômicos e políticos específicos.

Ainda que seja possível o estabelecimento de fundamentos metafísicos para o direito de propriedade - como o fez Kant, conforme anteriormente demonstrado -, não se deve desconsiderar que, na conformação prática do referido direito e na fixação das consequências jurídicas específicas, há que se voltar ao contexto político, econômico e social no qual ocorre a discussão a respeito de tal direito. $\mathrm{O}$ próprio Kant, também nos termos apontados, insistiu na necessidade do estabelecimento do denominado estado civil, como um pressuposto necessário para a efetivação do direito de propriedade.

O conteúdo do direito de propriedade, portanto, é dinâmico - tal como o reconhece Gilmar Mendes ${ }^{11}$ - e está submetido a um processo de relativização. Outros autores, como Frederico Henrique Viegas de Lima, referem-se a tal fenômeno aludindo às características de elasticidade e plasticidades do direito de propriedade. (Lima, 2010, p. 37)

Esse direito, dessa forma, não regulado de forma exauriente pelo constituinte, passa a ser conformado pelo legislador ordinário, que, por sua vez, longe de figurar em posição soberana em relação à matéria, está adstrito aos princípios constitucionais, notadamente ao princípio da proporcionalidade, que requer a demonstração efetiva, por parte de eventual limitador, da adequação, necessidade e proporcionalidade em sentido estrito. (Mendes, 2012, p. 158)

${ }^{11}$ A propósito do tema, esclarece o referido autor: "Não existe, todavia, um conceito constitucional fixo, estático, de propriedade, afigurando-se, fundamentalmente, legítimas não só as novas definições de conteúdo como a fixação de limites destinados a garantir a sua função social. É que, embora não aberto, o conceito constitucional de propriedade há de ser necessariamente dinâmico." (Mendes, 2012, p. 157) 
Os limites do legislador, assim, deverão ter como balizas o procedimento de ponderação de princípios, norteado notadamente pelo princípio da proporcionalidade, ${ }^{12}$ de modo a conformar o princípio da liberdade individual, respeitando a utilidade privada da coisa e o poder de disposição próprio do domínio, com eventuais interesses coletivos incidentes sobre o direito de propriedade. Nem o princípio da liberdade individual nem o interesse coletivo, consubstanciado no princípio da função social da propriedade, deverão ter seus núcleos essenciais suprimidos no exercício da ponderação.

Não se discute, portanto, a vinculação do legislador à observância dos direitos fundamentais. Trata-se de um dever de submeter-se, não só aos limites impostos pelos princípios constitucionais incidentes mas também de concretizar, na legislação ordinária, os preceitos fundamentais previstos na Constituição. Assim não o fazendo, sujeitar-se-á o legislador à censura direta do Judiciário, seja infirmando a legislação contrária aos limites constitucionais, seja por meio da censura pela omissão, via mandado de injunção, que poderá resultar, inclusive, na concretização de direitos pelo próprio Judiciário.

Da mesma forma, não se discute a vinculação do Executivo e do Judiciário em relação à observância dos direitos fundamentais. Não raras vezes, Executivo e Judiciário devem observar os limites impostos pelos direitos constitucionais individuais e atuar positivamente no sentido de concretizá-los.

Trata-se, nesse aspecto, da chamada eficácia vertical dos direitos fundamentais sempre que o ponto de referência do destinatário das normas se fixar nas entidades estatais. (Sarlet, 2000, p. 109)

Questão mais complexa, no entanto, se revela ao se examinar a eficácia dos direitos fundamentais no âmbito das relações privadas. Nesse caso, trata-se da eficácia horizontal dos direitos fundamentais.

De fato, a tradição liberal apregoa que as relações privadas são caracterizadas eminentemente pelos princípios da igualdade e autonomia. Assim sendo, deve-se

12 Sobre a aplicação do princípio da proporcionalidade no âmbito do direito de propriedade, explicita Gilmar Mendes: "A doutrina constitucional mais moderna enfatiza que, em se tratando de imposição de restrições a determinados direitos, deve-se indagar não apenas sobre a admissibilidade constitucional da restrição eventualmente fixada (reserva legal), mas também sobre a compatibilidade das restrições estabelecidas com o princípio da proporcionalidade. Essa nova orientação, que permitiu converter o princípio da reserva legal (Gesetzesvorbehalt) no princípio da reserva legal proporcional (Vorbehalt des verhältnismässigen Gesetzes)78, pressupõe não só a legitimidade dos meios utilizados $e$ dos fins perseguidos pelo legislador, mas também a adequação desses meios para consecução dos objetivos pretendidos (Geeignetheit) e a necessidade de sua utilização (Notwendigkeit oder Erforderlichkeit). Um juízo definitivo sobre a proporcionalidade ou razoabilidade da medida há de resultar da rigorosa ponderação entre o significado da intervenção para o atingido e os objetivos perseguidos pelo legislador (proporcionalidade ou razoabilidade em sentido estrito)" (Mendes, 2012, pp. 162-163) 
prestigiar a liberdade individual de conduta, partindo-se da premissa de que os agentes estão estabelecidos em um mesmo patamar decisório. Nesse contexto, os direitos fundamentais estariam a servir de instrumento contra o Estado, de modo a coibir a sua intervenção indevida no âmbito das relações privadas.

O tema foi debatido em $1^{\circ}$ de janeiro de 1958 no clássico julgado conhecido como Caso Lüth (BVerfGE 7, 198-230), pela Corte Constitucional alemã. A discussão teve origem no recurso constitucional interposto por Erich Lüth contra a condenação que havia sido lhe imposta, por um tribunal estadual, por ter se manifestado, por diversas vezes, em favor de um boicote ao filme intitulado "Amada Imortal", do diretor de cinema Veit Harlan, que se notabilizou no período da Segunda Guerra Mundial por ter lançado o filme “Jud Süss", de perfil antissemita. Com o final da Guerra, Veit Harlan lançou o seu filme acima mencionado, o que gerou a insurgência de Erich Lüth, então presidente do clube de imprensa de Hamburgo, que incentivou, por diversos meios, o boicote ao filme em questão, em razão do histórico do trabalho de Veit Harlan. Tendo em vista tal conduta, a produtora e a empresária do novo filme de Veit Harlan ingressaram com ação pleiteando que fosse determinada a cessação, por parte de Lüth, da emissão de suas opiniões em favor do boicote ao filme.

O tribunal estadual considerou, com fundamento no $\S 826$ do BGB, que a conduta seria contrária à moral e aos costumes, determinou que Lüth se omitisse de novas manifestações dessa natureza e impôs sensível pena pecuniária.

Muito embora sucumbente no tribunal estadual, Lüth acabou obtendo decisão da Corte Constitucional que reverteu a condenação que havia sido lhe imposta. Na oportunidade, considerou que o direito fundamental à liberdade de opinião deveria, sob um juízo de ponderação, prevalecer no caso concreto. Ao assim decidir, o tribunal concluiu pela necessidade de aplicação direta dos direitos fundamentais, por parte do Judiciário alemão, no âmbito das relações privadas, independentemente da legislação ordinária (BGB alemão).

Tal como observa Gilmar Mendes, é importante destacar que, nas hipóteses de aplicação de direitos fundamentais em benefício de um particular contra o Estado, o resultado é, normalmente, direcionado para a restrição da atuação estatal. No caso acima descrito, todavia, a eficácia dos direitos fundamentais volta-se para a relação entre privados, o que resulta no sacrifício do interesse de um, em benefício do reconhecimento do direito do outro. (Mendes, 2012, p. 128) 
Olindo Menezes, comentando as consequências do precedente em questão no constitucionalismo alemão, aponta que o Caso Lüth resultou nas seguintes conclusões: (i) a garantia jurídico-constitucional dos direitos individuais não se esgota no âmbito do cidadão em face do Estado; (ii) os princípios de direitos fundamentais não valem somente para a relação entre cidadão e Estado, mas também para todos os âmbitos do direito, irradiando efeitos para todo o sistema jurídico, o que resulta no caráter ubiquitário dos direitos fundamentais; e (iii) os valores, consubstanciados em princípios constitucionais, podem entrar em colisão, cuja solução exige o juízo de ponderação de bens, em superação ao mero juízo de subsunção do fato à norma. (Menezes, 2009, pp. 257-258)

Trata-se, assim, de caso paradigmático no desenvolvimento da teoria da eficácia mediata dos direitos fundamentais, que pressupõe a existência de colisões de princípios, que deverão ser resolvidos, caso necessário, inclusive pelos tribunais ordinários, por meio de procedimentos de ponderação. Em princípio, caberia ao legislador (e, na falta desse, ao juiz) interpretar o direito privado à luz dos direitos fundamentais, para que seja possível uma efetiva proteção dos direitos e garantias individuais previstos no texto constitucional, devendo-se preservar, em qualquer hipótese, o padrão mínimo exigido (Mendes, 2012, p. 129). Nesse sentido, deve-se reconhecer que os direitos fundamentais têm a função de preservação de um standard mínimo de liberdade individual. Isso não significa, todavia, que os provimentos normativos e jurisdicionais deverão reduzir a fruição de direitos ao standard mínimo.

Pela clareza e objetividade, oportunos se fazem os esclarecimentos de Ingo Sarlet a respeito da teoria da eficácia mediata dos direitos fundamentais:

Em última análise, isto significa que os direitos fundamentais não são - segundo esta concepção - diretamente oponíveis, como direitos subjetivos, nas relações entre particulares, mas que carecem de uma intermediação, isto é, de uma transposição a ser efetuada precipuamente pelo legislador e, na ausência de normas legais privadas, pelos órgãos judiciais, por meio de uma interpretação conforme aos direitos fundamentais e, eventualmente, por meio de uma integração jurisprudencial de eventuais lacunas, cuidando-se, na verdade, de uma espécie de recepção dos direitos fundamentais pelo Direito Privado. (Sarlet, 2000, pp. 123-124) 
A teoria em questão bem como o procedimento de ponderação não deixam de ser passíveis de críticas. De fato, não há uma ordem objetiva de valores que possa ser empregada de modo a se manter uma certa previsibilidade nas soluções dos conflitos levados ao Judiciário (Mendes, 2012, p. 130). A incerteza quanto ao resultado da prevalência de um princípio sobre outro poderia, em tese, resultar em decisões discricionárias e arbitrárias.

Como alternativa, surge a discussão relativa à teoria da state action, de origem norte-americana, que, ao contrário da doutrina alemã (relativa à teoria da eficácia mediata ou imediata) que apregoa a irradiação dos efeitos dos direitos fundamentais, objetiva investigar se o ato de um particular, que viola direitos constitucionais, poderia direta ou indiretamente ser imputado ao Estado (Menezes, 2009, p. 263). Segundo essa teoria (em alguma semelhança à teoria da convergência estatista na Alemanha), os direitos fundamentais vinculariam apenas o Estado e apenas contra ele deveriam ser invocados em face de uma ação estatal (state action). (Sarlet, 2000, p. 134)

Em que pese o reconhecimento de que alguns direitos fundamentais estão direcionados especificamente para a atuação do Estado em face do particular, é evidente, por outro lado, que princípios há que exigem, dos particulares, a observância direta dos seus respectivos postulados, inclusive no âmbito das relações privadas. Trata-se, na hipótese, da doutrina adepta à teoria da eficácia imediata dos direitos fundamentais.

Ingo Sarlet, um dos que, no âmbito da doutrina nacional, desenvolve a ideia de vinculação direta dos particulares ${ }^{13}$, com eficácia imediata de determinados direitos fundamentais, todavia, alerta que discussão mais importante do que aquela que se estabelece em torno da existência da vinculação direta ou não do particular, seria a que diz respeito a como se daria, de fato, essa vinculação. A propósito do tema. assevera o referido autor:

O problema, em verdade, não está em se advogar a tese da vinculação direta dos particulares aos direitos fundamentais,

\footnotetext{
13 Nesse sentido: "Da mesma forma, constata-se que os direitos fundamentais, na sua dupla dimensão objetiva e subjetiva também se fazem presentes - na esfera das relações entre particulares - tanto na condição de direitos a prestações (positivos) quanto na forma de direitos de defesa (negativos). Com efeito, tal se verifica quando as normas de direitos fundamentais impõem ao Estado deveres (gerais ou específicos) de proteção, gerando (e esta a dimensão prestacional) correspondentes posições jurídicosubjetivas (direitos à proteção), ainda que se possa discutir a respeito da força jurídica destes direitos. De outra parte, a função defensiva (negativa) se faz presente justamente na proteção da liberdade pessoal e demais bens fundamentais contra ingerências indevidas por parte dos poderes públicos e - o que mais importa neste contexto - também de agressões oriundas de outros sujeitos particulares" (Sarlet, 2000, p. 158)
} 
mas sim em avaliar qual a intensidade desta vinculação e quais as consequências práticas a serem extraídas no caso concreto, especialmente em face do reconhecimento da peculiaridade destas relações (entre particulares), decorrente da circunstância de se cuidar, em regra, de uma relação entre titulares de direitos fundamentais. (Sarlet, 2000, p. 156)

Para tais desafios, no entanto, é forçoso reconhecer que não há soluções simples nem uniformes que poderiam ser aplicadas incondicionalmente, de modo a se manter um determinado grau de previsibilidade. Volta-se, assim, à necessidade de estabelecimento de um procedimento de ponderação de valores, respeitando-se, conforme acima explicitado, padrões mínimos de fruição de direitos, na medida em que se estabelece, diante do caso concreto, a prevalência de determinados valores, sem a supressão, por completo, dos demais eventualmente incidentes.

No âmbito do Supremo Tribunal Federal, muito embora não se identifique uma farta jurisprudência sobre o tema, verifica-se que já houve o reconhecimento da necessidade de observância de direitos fundamentais, ainda que no âmbito de relações privadas.

A propósito do tema, e a mero título de ilustração, mencione-se o que restou decidido no Recurso Extraordinário 158.215, da relatoria do Min. Marco Aurélio. Na oportunidade, discutiu-se a respeito da necessidade de observância da garantia do contraditório e da ampla defesa, bem como do princípio do devido processo legal, no âmbito de procedimento de expulsão de associado de cooperativa. Confira-se, a propósito, a ementa do referido julgado, que consubstancia a decisão a que chegou a Segunda Turma do Supremo Tribunal Federal:

DEFESA - DEVIDO PROCESSO LEGAL - INCISO LV DO ROL DAS GARANTIAS CONSTITUCIONAIS EXAME - LEGISLAÇÃO COMUM. A intangibilidade do preceito constitucional assegurador do devido processo legal direciona ao exame da legislação comum. Daí a insubsistência da óptica segundo a qual a violência à Carta Política da República, suficiente a ensejar o conhecimento de extraordinário, há de ser direta e frontal. Caso a caso, compete 
ao Supremo Tribunal Federal exercer crivo sobre a matéria, distinguindo os recursos protelatórios daqueles em que versada, com procedência, a transgressão a texto constitucional, muito embora torne-se necessário, até mesmo, partir-se do que previsto na legislação comum. Entendimento diverso implica relegar à inocuidade dois princípios básicos em um Estado Democrático de Direito - o da legalidade e do devido processo legal, com a garantia da ampla defesa, sempre a pressuporem a consideração de normas estritamente legais. COOPERATIVA - EXCLUSÃO DE ASSOCIADO - CARÁTER PUNITIVO DEVIDO PROCESSO LEGAL. Na hipótese de exclusão de associado decorrente de conduta contrária aos estatutos, impõese a observância ao devido processo legal, viabilizado o exercício amplo da defesa. Simples desafio do associado à assembléia geral, no que toca à exclusão, não é de molde a atrair adoção de processo sumário. Observância obrigatória do próprio estatuto da cooperativa." (RE 158215, Relator(a): Min. MARCO AURÉLIO, SEGUNDA TURMA, julgado em 30/04/1996, DJ 07-06-1996 PP-19830 EMENT VOL-01831-02 PP-00307 RTJ VOL00164-02 PP-00757)

Verifica-se, assim, que o Supremo Tribunal Federal, no julgamento em questão, reconheceu que, ainda que no âmbito das relações privadas, em tese resguardas pela liberdade e pela autonomia, há a necessidade de observância de direitos e garantias fundamentais, como a garantia à ampla defesa, ao contraditório e ao princípio do devido processo legal. 


\section{O modelo democrático de propriedade}

\subsection{Uma teoria de direito sobre a propriedade privada}

Como visto anteriormente, a conceituação de direito de propriedade no Brasil está relacionada com os atributos da propriedade. Trata-se, à toda evidência, de uma tradição fortemente influenciada pelo positivismo jurídico que norteou a escola clássica civilista no país. ${ }^{14}$

Nessa linha, e a título de exemplificação, rememore-se a definição de direito de propriedade de Caio Mário da Silva Pereira, inspirada na redação literal do art. 1.228 do Código Civil - que por sua vez, como visto, tem origem no Código Napoleão. Para o referido autor - reverberado por tantos outros de nossa tradição - "a propriedade é o direito de usar, gozar e dispor da coisa, e reivindicá-la de quem injustamente a detenha”. (Pereira, 2014, p. 75)

A definição clássica do direito de propriedade, portanto, tem como objeto fundamental os direitos e prerrogativas que integram o conteúdo do direito de propriedade. A referência principal estabelece-se no âmbito da relação entre o sujeito e o objeto, e, principalmente, no que aquele poderá fazer deste.

É interessante notar que a definição em questão pressupõe uma certa estabilidade do conteúdo do direito de propriedade. Ou seja, definindo-se a propriedade por seu conteúdo, composto por determinados atributos, sua conceituação poderá restar descaracterizada caso se verifique, na prática, variações relevantes nos direitos e prerrogativas que a caracterizariam, segundo a definição clássica.

Nada obstante, conforme mencionado anteriormente - e para adotar a expressão utilizada por Frederico Viegas - a propriedade se caracteriza por uma determinada plasticidade. Em outras palavras, o conteúdo da propriedade pode perpassar por determinadas variações, sendo ora comprimido, ora expandido.

${ }^{14}$ Norberto Bobbio explicita as características principais do pensamento jus positivista, que muita demonstra bastante pertinência com a crítica ora formulada: "O positivismo jurídico representa, portanto, o estudo do direito como fato, não como valor: na definição do direito deve ser excluída toda qualificação que seja fundada num juízo de valor e que comporte a distinção do próprio direito em bom e mau, justo e injusto. O direito, objeto da ciência jurídica, é aquele que efetivamente se manifesta na realidade históricosocial; o juspositivista estuda tal direito real sem se perguntar se além deste existe também um direito ideal (como aquela natural), sem examinar se o primeiro corresponde ou não ao segundo e, sobretudo, sem fazer depender a validade do direito real da sua correspondência com o direito ideal." (Bobbio, 1995, p. 136) 
Nesse sentido, um exemplo clássico se refere ao direito de um determinado proprietário de definir a destinação de seus bens após o seu falecimento. Trata-se, a rigor, de um direito inerente à prerrogativa de dispor da coisa de que é titular. O conteúdo de tal prerrogativa, ou o alcance do referido poder, não é estável e varia nos ordenamentos jurídicos de países que adotam o sistema de direito de propriedade privada. De fato, verifica-se, por exemplo, nos Estados Unidos, uma grande liberdade do proprietário de dispor de seus bens em seu testamento, no qual lhe é lícito definir com bastante autonomia quem deverá receber, e em qual quantidade, o patrimônio deixado. Na Inglaterra e na Nova Zelândia, todavia, o direito de dispor da coisa em testamento é mais restrito. No direito brasileiro, como se sabe, há limitações ainda mais severas, notadamente no que concerne ao direito dos herdeiros em relação à herança legítima, que não poderá ser suprimida, sem justa causa.

Ora, se o conteúdo do direito de dispor da coisa é o que define, efetivamente, o direito de propriedade, haveria diferentes conceitos, um para cada ordenamento jurídico - a depender da extensão de seu conteúdo? Ou, ainda, como provoca Jeremy Waldron, o poder de transmissão por testamento não seria uma parte da definição de propriedade, mas estaria, apenas, contingencialmente conectado com ela? (Waldron, 2002, p. 29)

O conteúdo do direito de propriedade, portanto, e seus respectivos atributos são, de fato, contingenciais e dependem de contextos sociais e jurídicos específicos. Variam, assim, no tempo e no espaço. Tais aspectos não impedem, todavia, que se compreenda o sistema de propriedade privada a partir de determinados elementos que o caracterizam como tal.

Parece, portanto, ser mais apropriado, apreender o conceito de propriedade, não a partir de seu conteúdo - que é variável, como ora se afirma - mas, sim, a partir do entendimento de que se refere a um conceito de um sistema de regras que regulam o acesso e o controle relacionados a bens materiais. (Waldron, 2002, p. 31)

Conforme já se mencionou anteriormente, a questão relacionada ao direito de propriedade ganha relevo na medida em que se verifica a escassez de determinado recurso. De fato, no estado natural, tal como formulado por Locke, não havia nenhum tipo de restrição de acesso aos bens materiais, exatamente em razão da abundância e da possibilidade de serem satisfeitos os desejos e necessidades humanos relativos às coisas. Nesse cenário, a discussão em torno da propriedade perde relevo, pois não há razão que justifique a defesa de um determinado direito do titular do domínio de restringir o acesso de um terceiro a determinado bem que pode ser encontrado em abundância na natureza. 
A questão exsurge quando há fundamentos (razoáveis ou não razoáveis) para a discordância em relação ao emprego de determinada coisa para uma utilização específica, de modo que ela possa, de algum modo, afetar interesse alheio. Nesse cenário, a questão pode se tornar dramática, uma vez que a utilização de um recurso poderá resultar na restrição, pura e simples, de acesso dos demais a um bem da vida, muitas vezes necessário para a própria sobrevivência. O consumo concorrente, como visto no exemplo suscitado por Hardin, poderá resultar em tragédia (vide cap. 6, a respeito da Tragédia dos Comuns).

A análise, portanto, volta-se ao problema da alocação de recursos. A discussão se perfaz em relação à definição - e a partir de quais critérios - de quem será contemplado com determinado bem material e de que modo tal recurso poderá ser utilizado. Trata-se da estipulação de critérios legitimados por aspectos jurídicos, econômicos, políticos e sociais, de modo a reduzir conflitos relacionados a eventual discordância a respeito do emprego dos recursos.

Nesse sentido, o conceito de propriedade, conforme elaboração de Jeremy Waldron, está relacionado ao de um sistema de regras que regulamenta o acesso e o controle de recursos materiais, e que poderá atribuir a diversas pessoas direitos relativos a um mesmo recurso. (Waldron, 2002, p. 31/35)

Assim, em um sistema de propriedade privada, as regras que regulamentam o acesso e o controle a recursos materiais são organizadas em torno da ideia de que os recursos são objetos determinados e atribuídos - e, portanto, pertencentes - a uma pessoa específica. Nesse sistema, o titular do domínio relativo a algum bem material é considerado como aquele cuja determinação referente ao uso do recurso será considerada como final (Waldron, 2002, p. 37/38)

Deve-se destacar, todavia, que a atribuição a um determinado particular do poder decisório final a respeito da solução do problema da alocação de recursos não é a única forma de se resolver o problema relativo aos possíveis conflitos atinentes à utilização, acesso e controle de bens materiais. A propósito, poder-se-ia mencionar, como alternativa, e a título de ilustração, o sistema de propriedade coletiva, que, por sua vez, é caracterizado pelo fato de que a definição a respeito do controle e acesso a determinado recurso é realizada por uma regra social estipulada a partir do interesse coletivo prevalecente sobre a situação específica. Há, também, o sistema de propriedade comum, segundo o qual os recursos compartilhados pela comunidade poderiam ser utilizados, indistintamente, por cada um dos membros da coletividade. (Waldron, 2002, pp. 40-41) 
Diante disso, se faz oportuno indagar a respeito dos fundamentos que justificariam o sistema de propriedade privada, i.e., um sistema pelo qual se atribuiria a um determinado indivíduo o poder de decisão final a respeito da destinação e utilização de recursos escassos, em detrimento (na maioria das situações) da utilização pelos demais integrantes da sociedade.

Para tal finalidade, inicialmente, torna-se relevante consignar que os argumentos que sustentam o sistema de propriedade privada como forma de resolução do problema de alocação podem ser formulados - segundo a classificação suscitada por Jeremy Waldron (Waldron, 2002, p. 62 e ss.) - por perspectivas relacionadas a direitos, deveres ou finalidades (right-based, duty-based ou utility-based).

Tal como referido anteriormente, uma perspectiva fundamentada em argumentos de direitos considera como elemento suficiente o interesse individual, por si só, para justificar a adoção do sistema de propriedade privada como uma forma de resolução do problema de alocação. Mencionou-se, nesse sentido, a perspectiva de Hegel sobre propriedade como um dos clássicos exemplos de argumentos lastreados em direitos. De fato, como visto, a perspectiva hegeliana fundamenta-se no direito individual à liberdade, sendo ela considerada como uma exteriorização da personalidade de modo a permitir a experiência de sua autorrealização. O direito de propriedade, nesse sentido, justificar-seia no interesse relativo à liberdade, notadamente como forma de exteriorização individual.

Diferentemente, um argumento baseado em deveres considerará, v.g., a obediência a determinado preceito como o elemento fundamental para a justificação do sistema. A propósito, a teoria kantiana sobre ética - que, por sua vez, fundamenta a perspectiva de Kant sobre direito de propriedade - também anteriormente referida, é um exemplo clássico de teoria baseada no dever.

A perspectiva utilitarista, conforme também explorado anteriormente, objetiva justificar o sistema de propriedade privada com fundamento em critérios que consideram um determinado fim almejado. O critério utilitarista clássico, tal como formulado por Jeremy Bentham, objetiva estipular os meios mais eficientes para se alcançar a felicidade ou o bem-estar social. Posner, em sua formulação original - também de natureza finalística - defendia o critério de maximização da riqueza como fundamento de seus argumentos

É de se notar, a propósito, que, no Brasil, a partir do advento do princípio constitucional da função social da propriedade, autores de relevo passaram a considerar que o próprio conceito do direito de propriedade privada teria como elemento 
fundamental o atendimento a uma determinada função. Para a referida corrente, o elemento ético-valorativo que sustentaria o direito à propriedade privada seria a própria função social que a propriedade deveria alcançar. Tratar-se-ia, a rigor, de uma tendência contemporânea, a que faz referência Luiz Edson Fachin, de crescente "socialização da propriedade" (Fachin, 2011, p. 816).

Nesse sentido, confira-se, por exemplo, a posição de Carmen Lúcia Antunes Rocha:

O que parece certo é que, em princípio e por princípio, a propriedade presta-se a ser, em sua essência, algo dado a cumprir função, daí ser instrumental, voltada a um fim.

A função, em qualquer caso, é dar a utilidade que apresente resultado sociopolítico e econômico nos termos juridicamente definidos como legítimos. Paralelamente, a utilidade própria da coisa (res) é obtida pelo atendimento daquilo que é posto como sendo a sua função. (Rocha, 2004, p. 59)

Essa corrente, portanto, compreende o sistema de propriedade a partir de um determinado fim. Ou seja, a legitimação da propriedade privada estaria atrelada ao cumprimento de uma finalidade (função) social. Assim, caso o exercício do domínio não esteja norteado para o atendimento da finalidade almejada, a própria essência do direito restaria afetada, por carecer-lhe a legitimidade constitucional suficiente.

Essa posição, aliás, se aproxima do entendimento de Luiz Edson Fachin. Confirase, a propósito, o seguinte excerto:

A presente reflexão expôs suas premissas a partir de um paradoxo. De um lado, o avanço formal do texto constitucional brasileiro, apto a propiciar a tese que sustentamos, qual seja, o reconhecimento da ausência de proteção jurídica possessória à propriedade imobiliária que não cumpra sua função social; de outro, no entanto, convive a proclamação discursiva com a inefetividade social do acesso legítimo e democrático à terra. 
A função social da propriedade imobiliária rural, no direito brasileiro contemporâneo, pode ser elevada ao patamar de condição de existência da proteção jurídica do direito ao qual se reporta. (Fachin, 2008, p. 63)

É importante destacar, no entanto, que Fachin alerta que a função social da propriedade, em sua concepção, não altera a essência do direito de propriedade, mas sim o segmento relacionado ao uso. Nesse sentido, assevera:

A doutrina da função social da propriedade, corresponde a uma alteração conceitual do regime tradicional; não é, todavia, questão de essência, mas sim pertinente a uma parcela da propriedade que é a sua utilização. (Fachin, 1988, p.

Evidencia-se, assim, que o direito de propriedade, segundo a corrente anteriormente apresentada, estaria vinculado, e condicionado, ao cumprimento de determinada função social. Levando tal argumento às últimas consequências, portanto, o próprio direito de propriedade seria, em tese, suprimível, caso se constate o não atendimento da utilidade proposta. Na temática proposta por referida corrente, aliás, tratase da própria proteção possessória - como elemento de aparência do domínio -, cuja existência estaria ameaçada em caso de não cumprimento da função social. Assim, na hipótese da repulsa de esbulho possessório, o proprietário poderia ter considerado como ilícito o seu desforço imediato - na qualidade de prerrogativa decorrente da posse dirigido contra o invasor. Assim, sob a perspectiva da proteção possessória, a contrario sensu, poder-se-ia afirmar que a invasão de terras estaria legitimada - não podendo ser confrontada pelo possuidor originário - quando se detectar o não atendimento de uma função social da propriedade.

Não se desconsidera, como apontado anteriormente, que a Constituição Federal de 1988 trouxe condições objetivas, segundo as quais, o Estado poderia legitimamente desapropriar, mediante a observância de regras e procedimentos próprios, a propriedade rural que não atenda aos requisitos ali previstos. A rigor, a desapropriação se refere a procedimento por meio do qual o Estado retira a propriedade de alguém, com fundamento em normas jurídicas específicas. Ora, para que logicamente se possa retirar o direito de alguém, o direito prévio que se objetiva infirmar deve existir e, além disso, ser respeitado 
como tal - compreendido, portanto, nos planos da validade e eficácia. Dessa forma, muito embora o próprio texto constitucional legitime a conduta desapropriatória do Estado em determinadas condições (incluindo hipóteses em que a função social é, efetivamente, atendida), não parece ser razoável a interpretação no sentido de que a Constituição Federal teria feito incluir a função social como essência (tal como alerta Fachin) ou como condição de existência do próprio direito.

Trata-se, portanto, de uma perspectiva ético-valorativa, norteada por preceitos finalísticos (ou utilitaristas) que o texto Constitucional, por si só, não a sustenta. Ao contrário, o texto constitucional trata de princípios autônomos (proteção ao direito de propriedade e função social) que devem conviver harmonicamente no âmbito do mesmo sistema. Para tanto, as técnicas de ponderação de princípios, também já aludidas, poderão dar norte ao intérprete, em respeito ao Estado Democrático de Direito, evitando-se, v.g., a proteção insuficiente e/ou a mitigação do núcleo essencial de princípios.

Esse entendimento, aliás, é igualmente reverberado a partir do exame do histórico constitucional brasileiro, brevemente formulado no item 6.3, acima, que evidencia a premissa de que, quanto ao tema ora em discussão, não houve uma opção ideológica clara do constituinte no sentido de suprimir os ideais liberais que fundamentam o direito de propriedade no Brasil. Diferentemente, nota-se uma evolução do sistema, que, sem esvaziar por completo o conteúdo liberal dos princípios que fundamentam o direito de propriedade privada, abre-se a aspectos valorativos decorrentes do entendimento de que a propriedade, por sua relevância, deverá observar determinados anseios sociais, políticos e econômicos.

Isso não significa, todavia, que os fundamentos do direito de propriedade em nosso sistema são norteados por critérios utilitaristas. Até, porque, como visto acima, o conteúdo desse direito é caracterizado por uma certa elasticidade e poderá variar em certos aspectos; o que, todavia, não resultará na supressão de sua essência. Ou seja, por mais que, em determinadas circunstâncias - democraticamente legitimadas -, limitações ao direito de propriedade sejam impostas para o atendimento de um determinado fim social, a proteção ao direito em si, no que concerne ao seu núcleo essencial, restaria incólume.

Deve-se acrescentar, ainda, e reconhecendo-se que a ideia da função social é, por sua natureza, parte integrante de um sistema valorativo utilitarista, que cabe, uma vez mais, atentar aos necessários apontamentos realizados às premissas por ele sustentadas. De fato, como visto no capítulo 6 , há críticas importantes que não devem ser 
desconsideradas quanto à adoção indiscriminada de critérios utilitaristas para a formação dos fundamentos de sistemas ético-valorativos. ${ }^{15}$ A propósito, e em benefício da ênfase, reitere-se que Richard Posner (que muito embora também, à época, se valesse de argumentos finalísticos) sustentou que o utilitarismo, levado às últimas consequências, poderia legitimar a conduta da Alemanha nazista consistente na eliminação de judeus, na hipótese em que tal monstruoso resultado pudesse maximizar a felicidade de uma maioria intolerante. (Posner, 1979, p. 117)

Muito embora não se desconsidere a relevância (até porque o texto constitucional a estabelece) dos critérios relacionados à função social, há que se enfatizar a necessidade de observância de um direito à propriedade privada, legitimado única e tão somente pela importância do interesse individual envolvido. A legitimação do interesse individual, por si próprio, é o que fundamenta a impossibilidade do interesse majoritário de ultrapassar certos limites. Trata-se, assim, da própria essência que legitima o direito de um particular de estabelecer a sua decisão como a palavra final em relação à destinação de determinado bem da vida, ainda que contrária ao interesse majoritário.

A propósito, Robert Nozick coloca o ponto da seguinte forma:

Se a titularidade sobre os bens são os direitos de dispor deles, então a escolha social deve acontecer dentro dos limites do modo pelo qual as pessoas escolham exercer esses direitos. Se alguma padronização é legítima, ela está incluída na esfera da escolha social, e, consequentemente, está limitada pelos direitos das pessoas (Nozick, 2016, p. 214)

De fato, nos termos desenvolvidos anteriormente, os critérios utilitaristas não consideram aspectos morais individuais. Na medida em que determinados fins, ainda que de caráter social, são estabelecidos como elementos que norteiam determinada conduta tanto do Estado quanto de particulares - é possível que aspectos distintivos entre as

15 A propósito dos critérios utilitaristas relacionados ao direito de propriedade, Joseph William Singer faz as seguintes provocações: "If we are to pursue a utilitarian analysis that considers the consequences of different property regimes for social welfare, is economic efficiency the best way to measure costs and benefits of different property regimes? Are there other ways to measure the relative harms and benefits resulting from different property rules other than market values? Are all values commensurable, so that it would be rational for us to measure them on a single metric such as dollar values? If they are not commensurable, how do we compare incommensurable values? Is there a way to combine the best of justice language and utility language?" (Singer, 2000, p. 106) 
pessoas, como, v.g., preferências, valores, interesses, sejam desconsiderados. Nessa hipótese, a própria liberdade individual resta ameaçada.

John Rawls, a propósito, defende que os cidadãos são livres, basicamente, em razão do poder moral de cada um de estipular a sua própria concepção do bem; assim como da possibilidade de se auto compreenderem como entes legítimos para formular pretensões válidas. (Rawls, 2001, pp. 21-23) ${ }^{16}$

Uma teoria fundamentada em direitos, portanto, e não em objetivos de caráter finalísticos, pretende respeitar a distinção entre pessoas e defender a proibição do sacrifício de interesses individuais em benefício de um "bem maior". (Waldron, 2002, p. 73) Nessa hipótese, os interesses individuais se tornam a justificativa suficiente para submeter outros entes, públicos ou privados, a um dever relativo à criação, garantia, manutenção ou respeito da instituição da propriedade privada. (Waldron, 2002, p. 87)

Poder-se-ia objetar a premissa ora formulada atribuindo-a uma pecha relacionada a eventual promoção do egoísmo. Ora, ao se defender a imposição do interesse individual como barreira intransponível para o alcance de objetivos de uma determinada comunidade, o caráter egoístico de uma teoria de direitos efetivamente aflora.

Nada obstante, há dois aspectos relevantes que necessitam ser considerados como critérios de validação da defesa de determinado interesse individual em detrimento de finalidades de caráter social. Primeiramente, os interesses individuais, para serem legitimados, precisam ser universalizáveis. Ou seja, a sua proteção moral e jurídica precisa ser acessível a todos os seres humanos. Se egoísmo há, no argumento apresentado, ao menos trata-se de um egoísmo de caráter geral e acessível a todos. Em segundo lugar, há que se compreender o interesse individual defendido no âmbito de um sistema valorativo que o legitime. Assim, o interesse deverá ser validado, por sua relevância, em um contexto valorativo, ao ponto de legitimá-lo a ser considerado, por si só, como suficiente para ser protegido. (Waldron, 2002, p. 104)

Como exemplo de teoria que objetiva legitimar o direito de propriedade, em estrita consideração de ambos os aspectos acima descritos, poder-se-ia mencionar a perspectiva de Hegel sobre direito de propriedade. Em conformidade com o exposto anteriormente,

\footnotetext{
${ }^{16}$ Nesse sentido, assevera o referido autor: "First, citizens are free in that they conceive themselves and of one another as having the moral power to have a conception of good. (...) As free persons, citizens claim the right to view their persons as independent form and not identified with any particular conception of good, or scheme of final ends". (Rawls, 2001, p. 21) E, ainda: "A second respect in which citizens view themselves as free is that they regard themselves as self-authenticating sources of valid claims." (Rawls, 2001, p. 23)
} 
ele objetiva defender o direito de propriedade ao considerá-lo como uma manifestação da liberdade humana no sentido de possibilitar a exteriorização da individualidade do titular do domínio. Trata-se, a rigor, a propriedade privada, de elemento de relevância no âmbito de seu sistema valorativo, fundamentando a sua perspectiva de desenvolvimento ético do indivíduo, pela compreensão de que se refere a uma decorrência da liberdade humana. Tal premissa, inclusive, fundamenta a concepção de que o direito de propriedade, para Hegel, é universalizável.

Sob essa perspectiva, portanto, o direito de propriedade privada não serviria, apenas, como modo de suprir as necessidades básicas das pessoas. Trata-se, aliás, de uma das funções (sociais) relevantes do direito de propriedade a viabilização da própria sobrevivência humana.

Há, todavia, outras formas, além do sistema de propriedade privada, de se garantir a subsistência. Nesse sentido, as teorias marxistas, também anteriormente delineadas, constituem uma alternativa a ser considerada. Até porque, frise-se, as críticas resultantes da concepção de Marx acerca da ideia de materialismo histórico são relevantes e extremamente oportunas para a finalidade de explorar as mazelas decorrentes de um liberalismo clássico, então vigente na Europa ocidental.

Como visto, Marx expôs de forma contundente as relações de exploração existentes no âmbito das sociedades capitalistas. Defendeu que as condições humanas seriam diretamente determinadas pelas relações materiais, notadamente econômicas. Nesse sentido, em sua metáfora do edifício, procurou demonstrar que a infraestrutura de determinada sociedade, ao estabelecer seus alicerces econômicos em relações de exploração do homem (classe trabalhadora, representada pelo proletariado) pelos detentores do capital, resultaria em uma superestrutura (cultural, religiosa, política, etc.) caracterizada pela alienação exploratória que, meramente, refletiria as características das relações econômicas desequilibradas.

Em sua concepção, a libertação humana estaria relacionada, não a fatores metafísicos, mas à extinção da relação de exploração do homem pelo homem. Ou seja, para Marx, é fundamental o estabelecimento de um ideal de igualdade, no que concerne às relações materiais, para o fim de se verificar, efetivamente a liberdade humana. Propunha, nesse sentido, exatamente a extinção da propriedade privada, por considerar que apropriação material e a livre disponibilidade de recursos por uma determinada pessoa resultariam na concentração de riqueza e, por consequência, na renovação das relações de desequilíbrio e exploração. De fato, como visto acima, Marx afirmou que a 
existência da propriedade privada, tal como a conhecemos, apenas seria possível em razão de nove décimos dos integrantes da sociedade estarem desprovidos dela. (Marx \& Engels, 2006, p. 51)

A crítica de Marx, situada em contexto histórico e geográfico, é bastante pertinente. As relações de desequilíbrio existiram, à época da formulação de seu apontamento, e ainda hoje persistem. Portanto, exigem uma efetiva reflexão à luz de valores relevantes, inclusive, e principalmente, aqueles propagados pelo liberalismo, como liberdade, igualdade e autonomia. De fato, "não é possível libertar os homens enquanto não estiverem em condições de obter alimentação e bebida, habitação e vestimenta, em qualidade e quantidade adequadas" (Marx \& Engels, 1993, p. 65).

O direito de propriedade privada, nesse sentido, não prescinde de uma reflexão séria acerca de aspectos distributivos que, de alguma forma, fundamentem a compreensão de que o direito de disposição de recursos não pode e não deve ser absoluto e ilimitado, notadamente a ensejar a concentração de riqueza que resultará na privação do direito de propriedade dos demais. E não se trata aqui, reitere-se, da mera defesa do mínimo existencial.

Nos termos explicitados anteriormente, para Hegel, a propriedade privada é fundamental pois permite que o homem, ao controlar e dispor de coisas, exteriorize o seu livre arbítrio, corporifique materialmente a sua liberdade, e, dessa forma, transcenda a subjetividade de sua existência imediata.

Nesse sentido, uma pessoa desprovida de propriedade não chega, sequer, a se tornar capaz de se desenvolver eticamente e, externamente, gozar de sua liberdade, pela exteriorização de seu livre arbítrio. Não transcende a sua própria subjetividade. É inelegível para uma existência plena, conforme a perspectiva hegeliana. Mais grave, está fisicamente ameaçada de perecer por falta de condições mínimas de subsistência. Tratase, portanto, de questão de extrema relevância, em um contexto de fundamentação do direito de propriedade privada, segundo os dois critérios de validação acima mencionados.

A propósito do tema, assevera Hegel:

Com efeito, a carência natural como tal e a sua satisfação imediata apenas constituiriam o estado em que a espiritualidade se encontra prisioneira da natureza, seriam por conseguinte o estado de selvageria e de não-liberdade, pois a liberdade só existe na reflexão do espiritual em si mesmo, na 
sua distinção da natureza e na ação refletida sobre si. (Hegel, 2009, p. 176)

A relevância do direito de propriedade, assim, não se resume à mera satisfação das necessidades básicas de subsistência. Trata-se de elemento fundamental que viabiliza, materialmente, a transcendência do livre arbítrio. Apenas por meio da exteriorização de sua liberdade é que o ser humano tem a possibilidade plena de exercer a sua autonomia, de forma estável, e conforme seus próprios valores, de modo a ocupar o seu lugar como cidadão no âmbito de uma determinada sociedade. Caracteriza-se, portanto, muito além de instrumento para obtenção de condições materiais de subsistência, como elemento fundamental do desenvolvimento humano em seu caráter ético e político

Há que enfatizar, todavia, além dos fundamentos que relevam a necessidade de se considerar o interesse individual, por si só, que está subjacente ao direito de propriedade, o caráter de universalização do direito de propriedade.

Para tanto, reitere-se que o direito à propriedade não deve ser considerado como absoluto, por mais importante que o interesse pessoal possa se revelar. Nesse sentido, o conteúdo do direito de propriedade possui uma certa plasticidade que permite determinadas variações, sem que, com isso, seja descaracterizada a sua essência. Essa flexibilidade é extremamente relevante ao permitir que o direito de disposição da coisa possa ser limitado adequadamente, por meio de taxações, por exemplo, como forma de se considerar critérios distributivos que garantam o caráter universalizável do referido direito.

Nesse aspecto, os valores que norteiam a função social da propriedade - e, dessa forma, avaliações de natureza utilitarista que objetivem a garantia do bem-estar social se revelam de fundamental importância para garantir, não só a subsistência humana, mas o acesso à propriedade privada em medida que permita o pleno desenvolvimento ético e político, com profundo lastro valorativo no direito fundamental à liberdade.

7.2. Propriedade, relações sociais e democracia

O sistema de direito de propriedade privada, segundo Jeremy Waldron, nos termos acima explicitados, é um sistema organizado em torno da atribuição da decisão final a respeito da alocação de recursos a uma pessoa titular de um domínio. Trata-se, conforme argumentação delineada, de uma evolução relevante em relação à concepção tradicional 
do direito de propriedade, que, por sua vez, volta-se aos atributos (ou conteúdo) do referido direito, para conceituá-lo.

As teorias que se fundamentam na conceituação da propriedade a partir de seu conteúdo têm como perspectiva de análise a relação entre um sujeito, titular do domínio, e a coisa, objeto da titularidade. Não raras vezes, aliás, essa relação entre sujeito e objeto é o elemento que distingue o direito real do direito obrigacional (ou direito de crédito) que, por sua vez, seria caracterizado por uma relação entre uma ou mais pessoas.

Todavia, é de se reconhecer, como nos alerta Joseph William Singer, que os proprietários não vivem sozinhos (Singer, 2000, p. 9). Assim, também se torna necessário destacar que o exercício das prerrogativas que o direito de propriedade concede ao titular do domínio pode resultar em danos, ou afetar interesses de terceiros não proprietários. Quando o exercício de um determinado direito de propriedade causa algum dano, estarse-á diante do que se denomina de externality. (Singer, 2007, p. 3)

Ao se deparar com uma hipótese de eventual externality - mantendo a nomenclatura utilizada por Singer -, é de se analisar que o dano em questão poderá decorrer do exercício de um legítimo direito relacionado à propriedade privada. $\mathrm{E}$, ainda que o titular do domínio se mantenha nos limites da legitimidade jurídica - isoladamente examinada - de sua conduta como proprietário, é possível que um interesse válido de terceiro, não proprietário, também seja afetado.

Nessas hipóteses, a legitimidade moral que fundamenta o interesse legalmente protegido do titular do domínio de promover o pleno exercício de suas prerrogativas, como proprietário, pode não ser suficiente para justificar que o terceiro, também titular de um interesse válido, seja obrigado a suportar o sacrifício de seus direitos. Haverá, assim, a necessidade de se decidir qual interesse haverá de prevalecer, ou de ser conformado com o direito alheio, e, assim, de que modo será realizada a alocação do recurso no caso concreto.

Inevitavelmente, portanto, segundo nos alerta Singer, a instituição da propriedade levanta questões relativas às características das relações sociais e à natureza da governança. Nesse sentido, ainda segundo Singer, a propriedade é uma forma de poder, e a distribuição do poder é um problema de altíssimo relevo. (Singer, 2000, p. 9).

A concepção de Jeremy Waldron, como visto, procura analisar os fundamentos morais, considerando a relevância do bem protegido e a possibilidade de universalização, que legitimam a garantia do interesse em questão. Esse fundamento moral é que justificará a norma que regulamenta a conduta de terceiros não proprietários no sentido 
de respeitar o direito de propriedade do titular do domínio, e todas as prerrogativas que lhe são inerentes.

A evolução de Singer, em relação à perspectiva de Waldron, reside no reconhecimento de interesses alheios, dos não proprietários, quanto à percepção dos efeitos decorrentes do exercício das faculdades inerentes à propriedade. Há, dessa forma, que se avaliar, a partir do ponto de vista do interesse do terceiro afetado, se não persiste eventual pretensão válida que possa se contrapor às prerrogativas do titular do domínio. De certo, devem ser consideradas hipóteses em que também se verificará legitimidade moral na imposição de restrições à conduta do titular do domínio, em benefício do interesse do não proprietário.

Um clássico exemplo do que ora se assevera pode ser suscitado no âmbito do direito de vizinhança. Note-se, a título de ilustração, a discussão travada no âmbito do Superior Tribunal de Justiça, no julgamento do Recurso Especial n ${ }^{\circ}$ 1.096.639, a propósito do exercício de um dos direitos inerentes à propriedade por parte de uma sociedade empresária em Brasília.

Tratou-se, naquela oportunidade, de uma ação ajuizada por um condômino, pessoa física, que havia alugado um apartamento em condomínio que, por origem, teria destinação comercial, conforme, aliás, descrito na própria convenção condominial. De fato, como se sabe, trata-se de prática comum em Brasília - notadamente em decorrência da pouca oferta de imóveis na região do Plano Piloto e adjacências - a construção de edifícios em locais destinados, pela legislação urbanística, ao uso comercial, que, posteriormente, têm seu uso alterado para comportar a utilização dos imóveis para fins residenciais. Assim, é bem típico que, nesses edifícios, coexistam moradores, que utilizam seus respectivos imóveis para fins exclusivamente residenciais, e sociedades empresárias que desenvolvem atividades comerciais.

No caso em questão, insurgiu-se o condômino residencial contra a instalação, na laje superior à sua unidade imobiliária, de um aparelho utilizado para equipamentos frigoríficos de estabelecimento comercial instalado no mesmo edifício. Segundo o autor da ação, o equipamento em questão produzia ruídos e vibrações que afetavam a sua qualidade de vida. Diante disso, pleiteou fosse determinada a proibição de utilização do referido equipamento, bem como fosse a sociedade empresária condenada ao pagamento de indenização correspondente aos danos morais por ele percebidos. 
É importante destacar, a propósito, que a convenção condominial do edifício expressamente consignava que o imóvel seria destinado ao uso comercial, em respeito, aliás, às normas de gabarito que regem o respectivo endereço.

$\mathrm{Na}$ hipótese, portanto, o tribunal de origem e o Superior Tribunal de Justiça analisaram o direito de propriedade sob a perspectiva de interesses contrapostos relacionados ao uso do imóvel por parte do estabelecimento comercial. A rigor, a sociedade em questão, ao que consta dos autos, estaria em pleno exercício de suas prerrogativas inerentes à propriedade ao fazer uso de equipamentos necessários para a sua atividade comercial, em conformidade com a convenção de condomínio. Ainda assim, todavia, o Superior Tribunal de Justiça, nos termos do voto da ministra relatora Nancy Andrighi, considerou que o uso reiterado do imóvel para fins residenciais, há muito, teria superado a redação da convenção condominial, tornando-a obsoleta, nesse aspecto.

Trata-se de um típico conflito entre o exercício regular do direito, previsto em convenção de condomínio, de utilização de imóvel para fins residenciais, e do interesse do condômino morador que pretende ter seus sossego e tranquilidade garantidos (sem entrar em discussões relativas ao volume do ruído vis-à-vis as normas técnicas, por se tratar de questão alheia ao presente debate).

Uma perspectiva formalista dos direitos em discussão tenderia a considerar o título da propriedade comercial, bem como os efeitos e atributos jurídicos que dele decorreriam para o seu detentor, cotejando-os com a conduta da sociedade empresária, de modo a verificar se, de fato, houve uma extrapolação no exercício dos referidos direitos. Caso se verifique que a conduta se encontra amparada pelo arcabouço normativo ao qual a hipótese se subsome, o pedido do autor haveria de ser julgado improcedente.

Esse, aliás, foi o posicionamento do juiz de primeiro grau de jurisdição. Considerou que a convenção de condomínio respaldava a conduta da sociedade empresária, bem como que o nível de ruído apenas ultrapassava ligeiramente o permitido no horário noturno, quando, em tese, não haveria atividade comercial a ser prejudicada. Com esses fundamentos, julgou improcedentes os pedidos do autor.

Em segundo grau de jurisdição e no Superior Tribunal de Justiça, no entanto, a realidade prática relativa ao uso do empreendimento teria resultado na verificação do instituto da supressio, o que acabou por afastar a aplicação das normas da convenção. Exsurgiu, assim, a legitimação, pelas circunstâncias fáticas, do interesse do condômino morador a respeito da utilização, pela sociedade empresária, do imóvel em questão. Nesse contexto, e sopesados os interesses envolvidos, acabou por prevalecer o direito do autor 
à paz e à tranquilidade, inerentes à destinação residencial do imóvel em questão. Ao final, a sociedade empresária foi condenada ao pagamento de indenização por danos morais, restando prejudicado o pedido relativo à proibição do uso dos equipamentos, haja vista a mudança de endereço do estabelecimento comercial.

No caso, portanto, o Superior Tribunal de Justiça, diferentemente da decisão de primeiro grau, considerou ser oportuna a legitimação do direito de terceiro em relação ao uso da propriedade por parte do estabelecimento comercial, ainda que sob o respaldo de convenção de condomínio regularmente editada. Tendo sido considerada a relevância do interesse do condômino morador, foi ele confrontado com as prerrogativas inerentes ao direito de propriedade do imóvel no qual estava instalado o comércio. O resultado norteou-se no sentido da prevalência do direito do morador em detrimento do uso destinado pela sociedade empresária.

De fato, como acentua Singer, por mais que uma teoria de direitos se baseie na legitimidade moral que fundamenta a proteção jurídica de um determinado interesse, os direitos podem entrar em conflito, notadamente em razão da possível existência de outros interesses também relevantes sob perspectivas morais. Assim, o reconhecimento do direito de determinada pessoa poderá resultar em efeitos adversos a direitos de vizinhos, o que poderá exigir uma cuidadosa consideração de todas as consequências que decorrem de diferentes formas de se julgar o conflito de interesses, de modo a se sopesar as diversas pretensões, de fundamento moral, que eventualmente possam estar em jogo. (Singer, 2000, p. 116)

Nesse sentido, o referido autor defende que, em vez de se pretender desenvolver uma teoria de direitos que tenha por objetivo edificar uma esfera de proteção de interesses individuais contra intromissões de pretensões de uma coletividade, deve-se considerar que direitos conflitam e, por essa razão, é imperioso defini-los em termos das relações por eles formuladas. (Singer, 2000, p. 131)

Não por outra razão, Singer defende que - "property rights are best understood as legal rules that shapes the contours of human relationships regarding control of valuable resources" - (Singer, 2000, p. 134). Os direitos, portanto, devem ser interpretados - e em relação ao direito de propriedade não poderia ser diferente - de modo a considerar a forma como moldam as relações humanas, os deveres, responsabilidades, obrigações e, assim, as alocações de poder.

As regras relativas a direito de propriedade, portanto, acabam por interferir diretamente na criação e na manutenção de formas de estruturação das relações sociais. 
Não afetam, meramente, decisões individuais e oportunidades particulares para cidadãos; moldam e determinam padrões de interação social, com reflexos nas esferas econômicas, sociais e políticas no âmbito de uma determinada sociedade.

Ora, no processo de desenvolvimento de sistemas de interação social, econômica e política poderá incidir uma pluralidade de interesses e valores distintos. Nesse contexto, se, de algum modo, tais interesses - até eventualmente conflitantes - são passíveis de validação moral, para que, juridicamente, possam ser contemplados no âmbito normativo, devem necessariamente passar por um processo de legitimação política, o que, em nosso atual sistema, requer a observância dos princípios, normas e valores inerentes ao modelo de um Estado Democrático de Direito. ${ }^{17}$

Nesse exato sentido, assevera Singer: "whether the relationship is legitimate depends on a moral judgment that the relationship is acceptable in a free and democratic society" (Singer, 2009, p. 1048). Assim, em uma sociedade regida por valores consagrados no Estado Democrático de Direito, por mais que se defenda a liberdade individual e a autonomia decisória do titular do domínio em relação à utilização de um determinado recurso, há estipulações relacionadas ao direito de propriedade que se encontram vedadas em nosso ordenamento. São fartos os exemplos de valores relevantes consubstanciados em regras de Direito Civil - para nos restringirmos apenas ao Código - que criam limitações relevantes às estipulações privadas, como, v.g, o princípio da boafé objetiva, o instituto da lesão, da onerosidade excessiva, entre tantos outros.

Diante do exposto, é possível sistematizar algumas características do chamado modelo democrático de propriedade.

17 A propósito do tema, Joseph Singer faz relevante apontamento diante da relevância da propriedade no âmbito de uma sociedade caracterizada por pluralidade de valores a respeito de como se devem organizar as relações políticas e sociais: "Property law goes beyond managing the complexity of human interaction. Property not only presents a coordination problem but also a constitutional problem. Many issues fundamental to property law systems require attention to the norms, values, and ways of life that a society embraces. The problem is not just how to grease the wheels of social interaction; the problem is how to determine the character of that interaction. Value choices must be made to determine what property rights can be created, how many owners we should have, who can become an owner, how long rights last, and what obligations owners should have. Because we live in a free and democratic society that treats each person with equal concern and respect, we must interpret the fundamental values of liberty, equality, and democracy to define the set of property rights that we can recognize."

E acrescenta: "Property law is not simply about best management practices or coordination in the face of scarcity. Democracies elect leaders who pass laws that establish minimum standards for social and economic relationships compatible with our justified expectations and our considered judgments about what it means to treat others with dignity and respect. Property law is not just a mechanism of coordination; it is a quasi-constitutional framework for social life. Property is not merely the law of things. Property is the law of democracy." (Singer, 2014, p. 1287) 
A primeira delas, como acima exposto, considera que o direito de propriedade não se trata apenas de uma relação entre o titular do domínio e um objeto. Muito além disso, o direito de propriedade trata da relação interpessoal, regida por direitos e deveres, entre proprietários, não proprietários e o Estado.

O modelo democrático de propriedade, assim, objetiva ultrapassar a doutrina civilista tradicional que estrutura a conceituação do direito de propriedade em torno da relação entre titular do domínio, o objeto da propriedade e os respectivos atributos que caracterizariam essa relação. No âmbito de um Estado Democrático de Direito, e devidamente considerada a evolução valorativa em relação ao tema, que culminou com os princípios consubstanciados no texto atual da Constituição, não há mais como desconsiderar o contexto e os interesses que defluem das relações sociais em torno de decisões acerca da alocação de recursos relevantes para a sociedade.

De fato, a propriedade, como um direito, tem a ver com a conduta humana no âmbito de uma sociedade. Trata-se, assim, de regulamentar as relações sociais a partir da alocação de poder, inerente ao controle de um determinado recurso escasso, a uma pessoa específica (ou grupo de pessoas) em detrimento de outras. Refere-se, nesse sentido, ainda, ao modo e aos limites com o qual serão exercidos os direitos e prerrogativas relacionados à titularidade daquele recurso, considerando-se, evidentemente, o contexto social.

Diante de tal constatação, torna-se imperioso, ainda, o estabelecimento da perspectiva valorativa, com fundamentos morais, que irá nortear a análise acerca das relações sociais. Uma teoria libertária, por exemplo - como a de Nozick (Nozick, 2011) - tenderá a valorar de forma mais acentuada as transações voluntárias, evitando-se ao máximo a intromissão do Estado, como forma de se obter melhores resultados. O exame do tema sob viés da análise econômica do direito objetivará valorar a relação pelo critério de maximização de riqueza (ao menos na teoria original de Posner, acima referida).

O segundo aspecto relevante que caracteriza o modelo democrático de propriedade se refere ao entendimento de que, por se tratar o direito de propriedade como um fator relevante no âmbito das relações sociais, devem ser cuidadosamente sopesados os efeitos que poderão impactar em terceiros não proprietários, decorrentes do exercício dos direitos relacionados à propriedade. Como explorado acima, o titular do domínio não exerce os seus direitos isoladamente em uma redoma, alheia ao ambiente social externo no qual está inserido. Por essa razão, poderão advir as denominadas externalities, inclusive de um aparente exercício regular do direito de propriedade. 
Considerados, portanto, as relações interpessoais e os impactos que nelas poderá causar o titular do domínio, atribuem-se, nele, direitos e obrigações relacionados ao seu patrimônio, de modo a evitar ou mitigar eventuais externalities. Nesse sentido, assim, é necessário que os vários legítimos interesses eventualmente incidentes sejam contemplados, na discussão sobre propriedade, de modo a permitir que sejam conformados, ou, até mesmo, inobservados, diante de um valor maior a ser garantido. A análise e cotejo de interesses, no entanto, é imprescindível.

Tais constatações nos levam ao terceiro aspecto relevante do modelo ora tratado. Por mais que o direito de propriedade individual possa ser formulado com fundamento na relevância de um interesse particular universalizável e moralmente legítimo, por si só, não se deve desconsiderar que o referido direito integra um sistema social. Assim, no dizer de Joseph Singer, "property law is a part of the way we define a legitimate social order”. (Singer, 2009, p. 1049)

Desenvolver, portanto, o direito de propriedade no âmbito de determinada sociedade, trata-se de tarefa que não prescinde da discussão acerca do sistema social que a rege, bem como sobre a legitimidade dos efeitos, prerrogativas, direitos e deveres que deverão compor o conteúdo do direito de propriedade vis-à-vis os valores e princípios que norteiam o referido sistema.

Como destacado anteriormente, considerando o sistema social no qual o direito de propriedade está inserido, haverá hipóteses em que o espectro de discricionariedade de determinadas decisões individuais será tolhido, em razão da garantia de valores sociais relevantes. $^{18}$

Por fim, destaca-se que a propriedade é formada, para se utilizar a expressão de Joseph Singer, por "bundled rights" (ou direitos agrupados, em tradução livre) (Singer, 2009, p. 1050). Ou seja, o direito de propriedade, contextualizado no tempo e no espaço, está inserido no âmbito de uma determinada sociedade que é regida por valores, práticas, princípios e regras. Referido arcabouço normativo irá determinar que tipos de direitos poderão compor o conteúdo do direito de propriedade, assim como aqueles que não poderão ser contemplados. O proprietário, por exemplo, de um estabelecimento comercial tem uma relativa liberdade para fixar os preços de seus produtos (e consequentemente,

\footnotetext{
${ }^{18}$ A propósito do tema, Joseph Singer traz exemplo interessante: "However, if every person has the right to exclude others from his home, and if there is no place that a homeless person is allowed to sleep, then the allocation and exercise of the right to exclude has the cumulative effect of making it illegal for homeless persons to sleep anywhere. The right to exclude can only be legitimately asserted in such circumstances if there are places that homeless people are allowed to be." (Singer, 2009, p. 1050)
} 
sua margem de lucro), mas não poderá delimitar regras que impeçam determinados grupos de pessoas de comprar os seus produtos, com base, por exemplo, em critérios étnicos, de gênero ou de orientação afetiva. A rigor, no Brasil, a própria recusa de venda, por si só, é prática vedada pelo Código de Defesa do Consumidor.

O conteúdo da propriedade, formado por esses direitos agrupados, deverá ser estabelecido em estrita observância a critérios de legitimação que respeitem procedimentos democráticos, assim como as demais normas e princípios que regem o Estado Democrático de Direito.

Nesse aspecto, é importante considerar que o modelo democrático de propriedade pressupõe a legitimação de interesses múltiplos que podem eventualmente incidir sobre determinado domínio e o exercício dos direitos que lhe são inerentes. Essa legitimação pressupõe, de um lado, um procedimento democrático consentâneo com o ideal de Estado Democrático de Direito e, de outro, a compreensão de que os critérios de validação, ainda que democráticos, são formulados a partir de preceitos valorativos norteados por um determinado sistema moral político.

De fato, quanto ao procedimento democrático, é possível suscitar, ainda que genericamente, alguns fatores que bem caracterizam alguns dos valores inerentes a uma democracia.

O primeiro fator se refere à efetiva participação dos cidadãos no processo de tomada de decisões vinculativas. Devem eles ter a oportunidade adequada e igualitária para expressar as suas preferências em relação ao resultado final de uma determinada política. Devem ter adequadas e iguais oportunidades para formular questões quanto à agenda política e para expressar razões para sustentar um resultado em detrimento de outro. (Dahl, 1989, p. 109)

O segundo elemento apontado por Robert Dahl reside na igualdade na votação em etapas decisórias. Nesse aspecto, cada cidadão deverá ter assegurada uma igual oportunidade para expressar uma escolha que será considerada de peso equivalente à manifestada por qualquer outro cidadão. Na determinação dos resultados em etapas decisórias, essas escolhas, e apenas essas escolhas, deverão ser consideradas. (Dahl, 1989, p. 109)

O referido autor argumenta ainda que é possível, todavia, que, em determinadas situações de tomada de decisão, a ausência de informação, ou alguma outra forma de alienação, poderá resultar em má compreensão entre meios e fins, assim como em uma percepção equivocada em relação à valoração de determinado fim possível. Essa má 
compreensão ou ausência de informação poderão levar a resultados ou decisões que, em situações de acesso à informação ou de mitigação de um determinado fator de manipulação, não restariam prevalecentes. Diante disso, o entendimento adequado e equivalente a respeito dos elementos que caracterizam as escolhas em jogo também se constitui um pressuposto democrático relevante. De fato, o desequilíbrio informativo, ou de compreensão a respeito do que se está a decidir, poderá desvirtuar a escolha manifestada por determinados cidadãos, que, em outras circunstâncias, poderiam decidir de forma diferente.

Assim, defende Robert Dahl que cada cidadão deverá ter oportunidades adequadas e igualitárias para descobrir e validar (no período permitido pela necessidade de se tomar a decisão) a escolha referente à matéria a ser decidida que melhor atenda aos interesses dos cidadãos. (Dahl, 1989, p. 112)

Por fim, menciona-se, ainda, a necessidade de se submeter o controle da agenda decisória, igualmente, aos cidadãos. De fato, na medida em que determinados temas são excluídos dos processos de deliberação por parte dos cidadãos, verifica-se uma redução do poder decisório por força da regra da maioria, o que poderia levar, em tese, a uma mitigação do processo democrático. Nesse sentido, argumenta Dahl que os cidadãos devem ter a oportunidade exclusiva de decidir a respeito de que temas devem ser situados na agenda de assuntos que deverão ser decididos por meio de processos democráticos. (Dahl, 1989, p. 113)

Não se deve desconsiderar que determinados temas são explicitamente retirados da discussão democrática em razão de valores maiores. As denominadas cláusulas pétreas constituem um exemplo clássico de temas que não podem ser submetidos à deliberação. No âmbito da Constituição Federal de 1988, pode-se mencionar, a título de exemplificação, o artigo $60, \S 4^{\circ}$, que trata de temas que não poderão ser submetidos a deliberação no sentido de suprimi-los do texto:

Art. 60. A Constituição poderá ser emendada mediante proposta:

(...)

$\S 4^{\circ}$ Não será objeto de deliberação a proposta de emenda tendente a abolir:

I - a forma federativa de Estado; 


$$
\begin{aligned}
& \text { II - o voto direto, secreto, universal e periódico; } \\
& \text { III - a separação dos Poderes; } \\
& \text { IV - os direitos e garantias individuais. }
\end{aligned}
$$

Ainda assim, todavia, é de se destacar que, no caso brasileiro, o texto constitucional foi produzido no âmbito de um processo democrático (ainda que passível de críticas), por força do qual se estabeleceu, também por um processo decisório realizado por representantes eleitos, que os referidos direitos e princípios não poderiam ser objeto de deliberação tendente a aboli-los.

Evidentemente que os elementos formulados por Dahl, para caracterizar um procedimento democrático, são demasiadamente abertos e, portanto, sujeitos a interpretações e inúmeras críticas. Há, ainda, a dúvida relevante se, idealmente, ocorreu, na história da humanidade, alguma experiência política que tenha atendido rigorosamente a todos os requisitos acima especificados.

Tais apontamentos, assim como eventuais direcionamentos para os variados questionamentos que a teoria de Dahl enseja - por mais relevantes que sejam -, não comportam adequada discussão no âmbito do objeto deste trabalho.

Nada obstante, os fatores de validação do processo democrático apresentados por Dahl podem ser considerados como um norte a ser utilizado como referência para efeitos de legitimação de determinada decisão a respeito de temas relevantes para uma sociedade.

Entre tais temas, evidentemente, deve-se inserir as discussões relativas à alocação de recursos e aos direitos inerentes à propriedade, haja vista que, nos termos acima explicitados, trata-se de temática da mais alta relevância em termos políticos, econômicos e sociais, formulada por referências morais/valorativas das mais caras ao homem.

\subsection{Propriedade e democracia no Judiciário brasileiro}

Em que pesem os critérios, acima apresentados, que legitimam democraticamente o processo de tomada de decisão, não seria equivocado asseverar que a democracia significa - inclusive para vários autores como Locke, Rousseau, Aristóteles - que o poder de decidir estaria atribuído à maioria popular e aos seus representantes. (Dahl, 1957, p. 283) 
No âmbito de uma democracia representativa, a pluralidade de interesses que norteiam a escolha entre alternativas para se realizar determinada alocação de recursos (ou de poder) são intermediados por partidos ou grupos de pessoas que canalizam as pretensões, de modo a submetê-las à regra da maioria. Em tese, a escolha democrática será aquela fundamentada na decisão tomada pela maior quantidade de pessoas de uma determinada sociedade.

Não raras vezes, no entanto, o Judiciário é instado a tomar decisões relevantes a propósito de temas que afetam sensivelmente a questão da alocação de poder no âmbito do direito de propriedade. Trata-se de locus decisório que requer profunda reflexão, notadamente em razão de sua composição por membros escolhidos por critérios não definidos por meio da regra da maioria.

Tal aspecto torna-se ainda mais relevante ao se considerar a característica da atuação das cortes constitucionais. De fato, tal como assevera Gilmar Mendes, "na medida em que as cortes constitucionais se consolidam como órgãos de interpretação, elas passam a ser órgãos eminentemente políticos, não político-partidários, mas definidores dos limites de poder" (Mendes, 2017). Robert Dahl, no mesmo sentido, defende que, considerar a corte constitucional norte-americana apenas como uma instituição legal, seria subestimar a sua relevância no sistema político daquele país. ${ }^{19}$

Nesse contexto, a relevância democrática da atuação do Judiciário, notadamente do Supremo Tribunal Federal, no caso brasileiro, todavia, não se revela, tão somente, pelo endosso das alternativas escolhidas por força da regra da maioria. Ao contrário, a Corte Constitucional exerce função relevante de impor limites à atuação do Congresso, por uma atuação contramajoritária. O poder de exercer o controle de constitucionalidade é clássico exemplo de atuação do Poder Judiciário no sentido de mitigar a regra da maioria.

No que concerne especificamente ao direito de propriedade, o exercício do papel contramajoritário do Poder Judiciário se faz necessário para reforçar os fundamentos e valores que compõem a propriedade em nosso ordenamento. Ora, se estamos a tratar de um direito, cuja proteção se verifica apenas pela relevância do interesse individual a ser resguardado, por todos os fundamentos éticos anteriormente demonstrados, não há como

${ }^{19}$ Dahl, a propósito, assevera: "To consider the Supreme Court of the United States strictly as a legal institution is to underestimate its significance in the American political system. For it is also a political institution, an institution, that is to say, for arriving at decisions on controversial questions of national policy. As a political institution, the Court is highly unusual, not least because Americans are not quite willing to accept the fact that it is a political institution and not quite capable of denying it; so that frequently we take both positions at once." (Dahl, 1957, p. 279) 
não considerar a relevância da função do Judiciário para reforçá-lo diante de pretensões de uma coletividade que, eventualmente, possam conflitar com o poder decisório do titular do domínio.

De outro lado, todavia, e considerando a multiplicidade de interesses que poderão incidir sobre o direito de propriedade, o Judiciário também deverá estar aberto a contemplar tais pretensões, de modo a conformá-las com as prerrogativas do titular do domínio.

Assim o fazendo, cumpre importante função de mediação e legitimação de interesses relevantes, sob a perspectiva do Estado Democrático de Direito. A propósito do papel de legitimação política do Judiciário em uma democracia, assevera Robert Dahl:

Considered as a political system, democracy is a set of basic procedures for arriving at decisions. The operation of these procedures presupposes the existence of certain rights, obligations, liberties and restraints; in short, certain patterns of behavior. The existence of these patterns of behavior in turn presupposes widespread agreement (particularly among the politically active and influential segments of the population) on the validity and propriety of the behavior. Although its record is by no means lacking in serious blemishes, at its best the Court operates to confer legitimacy, not simply on the particular and parochial policies of the dominant political alliance, but upon the basic patterns of behavior required for the operation of a democracy. (Dahl, 1957, p. 295)

Vale ressaltar, todavia, que, conforme explicitado acima, a discussão sobre o conteúdo de propriedade envolve fundamentos ético-valorativos de extrema relevância. Acresça-se a isso que, não raro, o texto constitucional não enseja interpretações claras e previsíveis a respeito de escolhas já predeterminadas, para o fim de buscar por solução entre alternativas possíveis. Em outras palavras, muitas vezes a Constituição não explicita a escolha ético-valorativa a ser aplicável ao caso concreto, de modo a permitir uma composição de interesses consentânea com os valores da sociedade.

Para tal desiderato, as técnicas de ponderação de princípios, também já aludidas, poderão constituir ferramenta relevante para solução de casos difíceis. Análise acurada, 
todavia, da atuação do Poder Judiciário vis-à-vis o exercício da atividade legiferante por parte do Poder Legislativo é tarefa, por sua complexidade e sensibilidade, que não se adequa aos objetivos ora propostos.

Todavia, e para os fins da análise ora desenvolvida, é de fundamental importância o reconhecimento do caráter ético-valorativo da construção do conteúdo do direito de propriedade e da multiplicidade de valores que poderão incidir sobre o domínio. Nesse contexto, a legitimação das decisões do Judiciário a respeito dos problemas relativos à alocação de poder, no que concerne ao direito de propriedade, perpassarão por essa compreensão, como forma de se evitar que os fundamentos decisórios recaiam sobre valores e percepções ideológicas particulares de quem julga. Nessa hipótese, a decisão tomada carecerá da necessária legitimação democrática que o tema exige, notadamente se considerada a sua relevância no âmbito das relações sociais, políticas e econômicas.

Feitos tais breves comentários a respeito do papel do Judiciário no que concerne à formação do conteúdo do direito de propriedade, passa-se à análise de alguns casos relevantes sobre o tema, sob a perspectiva que norteia o modelo democrático de propriedade no contexto brasileiro.

7.3.1. Invasão de propriedade, reforma agrária e o direito de propriedade ("MS 24.764”)

A Companhia Brasileira de Equipamentos (“CBE”) impetrou, perante o Supremo Tribunal Federal, mandado de segurança contra decreto do Presidente da República, de 25.11.2003, que declarou de interesse social, para fins de reforma agrária, o imóvel rural Engenho Prado Grupo Prado, que seria composto pelos engenhos Prado, Tocos, Taquara e Dependência.

Em apertada síntese, os fundamentos da impetração seriam: (i) nulidade do processo administrativo preparatório da desapropriação por cerceamento de defesa; (ii) o imóvel teria sido objeto de cinco diferentes vistorias, o que teria resultado na invalidade das conclusões a que se chegara quanto à produtividade do imóvel; e (iii) a análise quanto à alegada improdutividade do imóvel estaria comprometida, em razão de invasão da propriedade por integrantes do "movimento dos trabalhadores sem-terra".

O ministro Maurício Corrêa, no exercício da Presidência da Corte, houve por bem negar a liminar pleiteada, em virtude da "complexidade dos fatos narrados na inicial e o 
teor da documentação juntada" (f. 170). Referida decisão restou confirmada pelo ministro Sepúlveda Pertence, a quem o mandado de segurança foi distribuído.

Nada obstante, diante da iminência da efetivação da desapropriação, o ministro relator, posteriormente, reconsiderou o seu posicionamento anterior e deferiu o pedido de liminar para suspender o processo desapropriatório até o julgamento final do mandado de segurança.

No âmbito do julgamento do mandado de segurança, no plenário do Supremo Tribunal Federal, o ministro relator votou no seguinte sentido: (i) diante da constatação da efetiva atuação da defesa do impetrante no processo administrativo, entendeu não haver cerceamento de defesa; (ii) considerou improcedente o argumento de que o imóvel seria caracterizado por uma unicidade, ainda que composto por glebas com matrículas distintas, razão pela qual não se poderia invalidar as vistorias distintas para cada uma das matrículas; e (iii) rejeitou a alegação de que a invasão dos trabalhadores sem-terra obstaria a constatação da improdutividade da propriedade.

Para os fins relacionados à discussão que se pretende, o ponto principal reside no argumento suscitado pelo impetrante quanto à possibilidade de se impor a desapropriação de caráter sancionatório, em razão da ausência de atendimento da função social da propriedade - verificada a partir de critérios de produtividade -, em hipótese na qual se havia constatado a ocorrência de invasão do movimento dos sem-terra.

O ministro Sepúlveda Pertence rejeitou a alegação do impetrante, nesse aspecto, por considerar que a ocupação se restringiria a apenas uma gleba, o Engenho Prado, que não estava incluída no decreto de desapropriação. A outra supostamente afetada, Engenho Dependência, teria sido "palco de conflitos entre posseiros antigos e proprietária", segundo as informações prestadas, sendo certo que a área afetada se restringiria a “aproximadamente 19 hectares (doc. 44, terceiro parágrafo), constituindo-se, portanto, em ínfima parcela da área total do imóvel - 4.591,71 hectare - que não poderia justificar o estado de improdutividade do mesmo, segundo reiterada jurisprudência do STF".

De fato, a jurisprudência do Supremo Tribunal Federal, até então, havia sido firmada no sentido de que a invasão de fração diminuta do latifúndio não obstaria a desapropriação por não atendimento da função social da propriedade, em razão da ausência de produtividade consentânea com o uso que se espera de uma propriedade rural.

A propósito, confira-se a ementa do entendimento que restou consubstanciado no Mandado de Segurança ${ }^{\circ}$ 23054, também da relatoria do ministro Sepúlveda Pertence: 
Desapropriação para reforma agrária: validade. 1 . Decreto 2250/97: proibição de vistoria preparatória da desapropriação enquanto não cessada a ocupação do imóvel por terceiros: inaplicabilidade, à vista da omissão da portaria do INCRA, que lhe fixasse os termos e condições de aplicação. 2. Improdutividade do imóvel rural - de bucólica virgindade, mal bulida pelos arrendatários - que seria risível atribuir, a título de força maior, à ocupação por "sem terras", uma semana antes da vistoria, de fração diminuta do latifúndio. (MS 23054, Relator(a): Min. SEPÚLVEDA PERTENCE, Tribunal Pleno, julgado em 15/06/2000, DJ 04-05-2001 PP-00005 EMENT VOL-02029-02 PP-00337)

Com fundamento, portanto, no entendimento de que a fração envolvida nos conflitos seria diminuta, a se considerar a área total do imóvel, o ministro relator, apoiando-se na jurisprudência do Supremo Tribunal Federal, concluiu que não havia razão para se impedir o reconhecimento da improdutividade da propriedade, como condição para a efetivação da desapropriação.

O ministro Gilmar Mendes, todavia, abriu divergência, especificamente quanto à possibilidade de se manter o ônus, ao proprietário, no que concerne à produtividade, em relação à terra que se encontra invadida. O ministro fundamentou seu voto nos seguintes termos:

Sra. Presidente, tenho profundas dúvidas quanto à terra invadida.

Se tal invasão for na porteira de uma propriedade, compromete radicalmente a administração do imóvel.

Não me sinto habilitado - talvez por ser da área rural e conhecer um pouco o tema - a fazer esse tipo de 'distinguishing'. Não consigo conviver com a ideia de que se possa ter alguém dentro da propriedade, perturbando o exercício, turbando a posse e ainda assim o seu titular consiga manter a propriedade em funcionamento, especialmente se a invasão estiver localizada, como sói acontecer, em áreas onde haja água, passagens, caminhos. 
É de se indagar: como é que se convive com tal estado de coisas? Quem tem um mínimo de experiência sabe: e vinte hectares em quatrocentos hectares é algo significativo.

De modo que, em relação a esta propriedade - Gleba Dependência -, eu concedo a ordem.

$\mathrm{O}$ entendimento do ministro Gilmar Mendes, quanto à parcial procedência do mandado de segurança, para o fim de excluir a Gleba Dependência do processo de desapropriação, em razão da constatação de invasão por trabalhadores do movimento dos sem-terra, acabou prevalecendo no julgamento em plenário. Ficaram vencidos, nesse particular, os ministros Sepúlveda Pertence, Eros Grau, Joaquim Barbosa e Cezar Peluso.

O caso ora apresentado demonstra de forma bastante clara a possibilidade de existência de interesses diversos (e conflitantes) em relação a um determinado objeto de domínio. No particular, evidencia-se o interesse individual, do titular, em manter a sua propriedade a salvo do processo de desapropriação, de modo a se garantir a sua prerrogativa de decidir a respeito da destinação das glebas em questão. De outro, verificase o interesse dos trabalhadores rurais sem-terra de ter incluídas as propriedades em questão no programa de reforma agrária, para que seja viabilizado o acesso de não proprietários a propriedades imobiliárias rurais.

Os dois interesses contrapostos são moralmente relevantes e, em tese, amparados constitucionalmente. $\mathrm{O}$ direito de propriedade é, efetivamente, um direito fundamental, e tem sua essência maior na liberdade humana. O interesse dos sem-terra apoia-se no princípio da função social da propriedade, que impõe um ônus ao detentor do título de manter a propriedade produtiva e no direito à propriedade, em seu caráter de universalização.

É de se notar, no caso específico da propriedade rural, que o legislador estabeleceu os parâmetros normativos para se verificar, concretamente, o atendimento ao princípio da função social da propriedade. A Lei 8.629/93 traz critérios bastante objetivos, balizando a tarefa do intérprete, para se tornar efetivo o aspecto da função social da propriedade. Ou seja, democraticamente foram estabelecidos os fins sociais almejados com o exercício dos direitos relativos à propriedade rural, quais sejam, em suma: (i) o desenvolvimento econômico, com geração de renda e emprego, a partir da aferição do critério da produtividade; e (ii) o ideal de pleno acesso à propriedade rural aos trabalhadores não 
proprietários, por meio da reforma agrária, fomentada pela disponibilização das propriedades rurais improdutivas.

Estes, portanto, em suma e no particular, foram os fins sociais estabelecidos democraticamente. São critérios de natureza utilitarista, pois objetivam o alcance de determinada utilidade social almejada segundo a regra da maioria.

Assim, essa regra, enquanto amparada eticamente por valores sociais relevantes, pode e deve ser legitimada democraticamente, para o fim de ser devidamente sopesada com os demais interesses em jogo, sejam aqueles do particular, proprietário, sejam aqueles difusos (como, p. ex., direito ao meio ambiente).

Há que se destacar, todavia, que, diante de um direito de caráter genérico, poderá haver um direito particular a uma determinada coisa que poderá obstar as pretensões da coletividade. Ou seja, a uma pretensão de caráter genérico e indeterminado à propriedade, poderá ser imposto, a ela se sobrepondo, um direito preexistente em relação à coisa determinada. É o que chama atenção Jeremy Waldron, a partir da teoria de Robert Nozick. (Waldron, 2005, p. 81)

Ainda assim, conforme explicita Jeremy Waldron, as teorias libertárias, como a de Robert Nozick, devem ser confrontadas com o dever moral de caridade, nos termos em que Locke já havia formulado (conforme explicitados anteriormente no item 3.1), que intitula indivíduos a determinadas pretensões relativas à propriedade, considerando que, de outra forma, não disporiam de meios materiais de sobrevivência. (Waldron, 2005, p. 110)

É dizer: a propriedade obriga.

A propriedade hodierna, portanto, não mantendo seu caráter absoluto (se é que já o foi em algum momento), impõe deveres ao titular do domínio, de modo a contemplar os interesses de não proprietários. E tais deveres, frise-se, fundamentam-se na ideia de que o direito de propriedade tem, em seu núcleo, um relevante caráter relacional entre indivíduos, e/ou entre proprietário e Estado, e/ou, ainda, entre proprietário e uma coletividade difusamente considerada. Trata-se, nos termos acima explicitados, da consideração do outro a que alude Joseph Singer, o que demonstra a superação da compreensão do direito de propriedade como uma relação meramente formada entre um sujeito e um objeto.

No caso específico, todavia, considerou-se, para obstar a desapropriação da propriedade do impetrante, a existência de invasão dos trabalhadores sem-terra. Esta, 
ainda que em parcela menor, se cotejada com o total da área da gleba, estaria impedindo o pleno exercício do direito de propriedade.

Ou seja, considerou-se que o direito de propriedade restaria fatalmente afetado pela existência de uma ocupação, e de uma situação de conflito agrário, que estaria a impedir o pleno exercício das prerrogativas do proprietário. Nesse contexto, infirmado, na essência, o direito de propriedade, pelo impedimento físico do exercício de seus atributos, não haveria, sequer, como se avaliar se o exercício do direito estaria em conformidade com a função social da propriedade. Ora, se a propriedade impõe ao proprietário o dever de mantê-la produtiva para, inclusive, atender ao fim utilitarista almejado pela sociedade, os seus atributos precisam manter-se incólumes para que ele, pelo seu exercício, possa, efetivamente, dar a ela a devida destinação. Logicamente, a propriedade - com a preservação dos seus respectivos atributos - precede a obrigação que dela decorre.

Assim, se ao proprietário, por motivo de força maior, é subtraída a prerrogativa de exercer a propriedade, não se pode sancioná-lo por descumprimento de obrigação que supostamente não restou atendida.

O caso em questão, igualmente, demonstra de forma cabal que a função social da propriedade não é condição de verificação do direito de propriedade. Diferentemente, o direito de propriedade, quando garantido, ou seja, existente, válido e eficaz, impõe ao proprietário determinadas obrigações.

E tais obrigações, enfatize-se, devem considerar, de um lado, o lastro moral relevante que a fundamenta e as torna cotejáveis com aqueles interesses individuais inerentes à propriedade; e, de outro lado, a devida legitimação democrática que torna tais obrigações exigíveis, sob a perspectiva jurídica, no âmbito de um Estado Democrático de Direito.

7.3.2. A função social da propriedade e o solo criado. (“RE 387047”)

O Recurso Extraordinário no 387.047/SC foi interposto por Koerich Participações e Administração Ltda. em autos de mandado de segurança ajuizado em face de ato do Prefeito Municipal de Florianópolis, de seu Secretário de Finanças e do Chefe do Serviço de Arrecadação do Município de Florianópolis, com o propósito de abster-se do pagamento da "parcela do solo criado". 
Alegou, à época, o impetrante/recorrente que, para a obtenção do alvará de construção lhe teria sido exigido o pagamento da "parcela de solo criado", instituída pela Lei Municipal 3.338/89, a qual, em seu entendimento, consistiria em verdadeiro tributo. Diante disso, e considerando tratar-se de matéria de competência da União, a imposição do tributo em questão seria inconstitucional.

No âmbito dos graus ordinários de jurisdição, a alegação de inconstitucionalidade da cobrança da contrapartida pecuniária correspondente ao "solo criado" foi rechaçada. Diante disso, foi interposto recurso extraordinário, no qual foi reiterado o argumento do recorrente no sentido de que a hipótese discutida se caracteriza como verdadeiro imposto.

O ministro relator Eros Grau esclareceu, em seu voto, que a o Município de Florianópolis instituiu, por meio da Lei 3.338, de dezembro de 1989, a denominada "parcela do solo criado". Essa parcela tem suas origens em seminários ocorridos na década de 1970, em São Paulo, cujos trabalhos e discussões teriam resultado na Carta de Embu, subscrita por juristas, arquitetos e urbanistas. Os debates desenvolvidos nos referidos seminários e a evolução da discussão sobre o tema culminaram com a previsão, no âmbito do Estatuto das Cidades, do instituto da outorga onerosa do direito de construir.

O artigo 28 da Lei 10.257/01 (Estatuto das Cidades), quanto ao instituto da chamada outorga onerosa, especifica que o direito de construir poderá ser exercido acima do coeficiente de aproveitamento básico adotado, mediante contrapartida a ser prestada pelo beneficiário.

Como bem aponta o ministro relator em seu voto, o denominado "solo criado" semelhante à ideia da outorga onerosa - não se confunde com o mero direito de construir ocupando-se o espaço aéreo. Em bem oportuna analogia, esclarece que as catedrais góticas muito avançam para o alto, sem, contudo, efetivamente "criar solo", artificialmente, por construções civis. O "solo criado", dessa forma, está relacionado a um aumento do coeficiente de aproveitamento básico do terreno no qual se ergue um determinado edifício.

Nesse sentido, esclarece o ministro Eros Grau nos seguintes termos: "sendo assim, se tal coeficiente for igual a 1 (um), considerar-se-á solo criado a área que ultrapasse, em metros quadrados, o valor equivalente ao da área do terreno".

O instituto do "solo criado", assim como acontece com a outorga onerosa, pressupõe que, para que o proprietário possa construir além do coeficiente de aproveitamento básico previsto nas normas de gabarito para determinado endereço, terá 
ele, proprietário, de adquirir, mediante contrapartidas, o direito de edificar o que sobejar, em seu projeto, ao referido coeficiente.

Diante disso, o ministro relator entendeu que a cobrança da contrapartida pecuniária, pelo Município de Florianópolis, não se confundiria com a imposição de tributo, cujo fato gerador seria, no entendimento do impetrante/recorrente, a "criação" do solo.

Para tanto, o ministro Eros Grau promoveu uma minuciosa explanação em relação à diferenciação entre os conceitos jurídicos de obrigação, dever e ônus. Nesse sentido, explicou que a tributação se refere a prestação de caráter obrigacional.

A obrigação, segundo o voto condutor, consubstancia um vínculo entre um credor e o devedor, por força do qual este deve àquele uma determinada prestação. Referido dever se caracterizaria por uma sujeição do devedor ao credor em relação à obrigação. Ou seja, a vontade do devedor seria conformada para o pagamento da prestação em benefício de interesse alheio (do detentor do crédito). Não cumprido o dever de prestação, o devedor estará sujeito à execução forçada ou, ainda, à responsabilização patrimonial correspondente à prestação inadimplida. Assim, o devedor tem, perante o credor, um dever sancionado pelo direito.

Assim, frisa o ministro Eros Grau que a obrigação - e por consequência a obrigação tributária - estaria relacionada à ideia de dever. Nesse sentido, reitera que, na obrigação - tal como no dever -, “o cumprimento da obrigação prestação, pelo devedor, importa em atendimento de interesse alheio, isto é, do credor". O descumprimento da prestação, por outro lado, é juridicamente sancionado. No que concerne à obrigação tributária, portanto, o pagamento do tributo, pelo particular, implicaria na satisfação do interesse do Estado.

Diferentemente, o ônus estaria caracterizado quando "o exercício de uma faculdade é definido como condição para obtenção de certa vantagem". Assim, ele também estaria relacionado à ideia de vinculação da vontade de quem irá suportá-lo. Essa vinculação, no entanto, teria como objetivo final a satisfação de interesse próprio. Ou seja, no dizer do ministro Eros Grau "dever e ônus têm em comum o elemento formal, consistente no vínculo à vontade, mas diverso o elemento substancial, porque o vínculo é imposto, quando se trata de dever, no interesse alheio, e, tratando-se de ônus, para a tutela de um interesse próprio".

Tais distinções também produzem reflexos quanto aos efeitos do inadimplemento das prestações consubstanciadas em uma obrigação, de um lado, e em um ônus, de outro. 
Considerando que, ao se tratar de um ônus, a vinculação da vontade diz respeito ao atendimento de um interesse próprio, a sanção pelo inadimplemento da prestação resultará em uma desvantagem econômica. Diferentemente, se uma prestação relativa a uma obrigação for inadimplida, recairá, sobre o devedor e seus bens, uma sanção jurídica, a ser viabilizada por instrumentos executivos atribuídos ao credor da obrigação.

Diante disso, o ministro Eros Grau definiu o ônus como sendo "o instrumento através do qual o ordenamento jurídico impõe ao sujeito um determinado comportamento, que deverá ser adotado se ele não pretender arcar com consequências que lhe serão prejudiciais", e conclui: "ou como um comportamento que o sujeito deve adotar para alcançar uma determinada vantagem, que consiste na aquisição ou na conservação de um direito".

Feitas tais distinções, concluiu o ministro Eros Grau que a contrapartida pecuniária exigida pela municipalidade para o fim de se permitir a edificação do "solo criado" consistiria em verdadeiro ônus, e não em obrigação tributária. De fato, a cobrança da referida prestação se caracteriza como uma condição para - com o propósito de atendimento de interesse próprio do proprietário - se permitir a efetivação de construção além do coeficiente de aproveitamento previsto na norma de gabarito incidente.

O descumprimento, portanto, da prestação de pagar pela permissão da municipalidade de se promover a construção acima do coeficiente implicaria em uma desvantagem econômica ao proprietário, e não na caracterização de um ilícito. Não efetivando o pagamento da contraprestação pecuniária, o proprietário restaria tolhido de sua prerrogativa de construir além do coeficiente de aproveitamento previsto para o respectivo imóvel. Ao não o fazer, no entanto, não estaria sujeito à sanção jurídica por cometimento de ato ilícito.

Com tais considerações, o ministro relator concluiu que o instituto do "solo criado" não se confundiria com obrigação tributária, razão pela qual não havia que se falar em inconstitucionalidade.

Por fim, em conclusão, o ministro Eros Grau traz relevantes apontamentos a respeito da importância do instituto em relação à política urbana e em conformação do direito de propriedade à sua função social:

O instituto que corresponde a chamada "parcela do solo criado" envolve a imposição de um ônus ao proprietário do imóvel urbano. É instrumento próprio à política de 
desenvolvimento urbano. Política cuja execução incumbe ao Poder Público municipal, nos termos do disposto no artigo 182 da Constituição do Brasil, instrumento vocacionado à correção de uma série de distorções que o crescimento urbano desordenado acarreta, adequado à promoção do pleno desenvolvimento das funções da cidade e a dar concreção do princípio da função social da propriedade (art. 170, III da CB).

De fato, o instituto da outorga onerosa suscita reflexões relevantes, não só em relação à natureza jurídica do instituto, mas, igualmente, em relação ao direito de propriedade, o exercício das prerrogativas do proprietário e o contexto urbano no qual o imóvel está inserido. Ora, o pressuposto político-valorativo da criação do instituto reside exatamente na compreensão de que o aproveitamento de determinado imóvel para o fim de realização de empreendimento imobiliário está relacionado a impactos relevantes no meio urbano e social.

Um determinado empreendimento imobiliário, quando concluído e devidamente ocupado, importará em provável adensamento de pessoas e/ou automóveis em determinada região. Referido aspecto evidencia acréscimo de carga sobre a infraestrutura urbana que atende a região em apreço. Ou seja, ao ultrapassar o coeficiente de aproveitamento previsto para determinada região, poderá haver uma pressão maior sobre a mencionada infraestrutura, o que eventualmente, inclusive, exigirá do Poder Público um aumento de investimentos para que a população acrescida - além da anteriormente existente - seja devidamente contemplada com elementos urbanísticos básicos, como fornecimento de energia elétrica, abastecimento de água, equipamentos públicos, vias adequadas, etc.

Não por outra razão, alerta Victor Carvalho Pinto que "o coeficiente máximo deve considerar 'a proporcionalidade entre a infraestrutura existente e o aumento de densidade esperado em cada área" (Pinto, 2014, p. 250)

O exercício de um clássico atributo do direito de propriedade, consistente na construção de edifício nos limites do imóvel, quando efetivado, portanto, acima de um determinado limite de aproveitamento, ao provocar um aumento no adensamento e, por consequência, na sobrecarga no sistema de infraestrutura urbana, evidenciará o que se denominou, anteriormente, de externalities. 
Pressupõe-se, assim, que o proprietário do imóvel deverá promover uma compensação à municipalidade, que, a rigor, no caso, intermedeia os interesses coletivos e individuais envolvidos. Para a fixação da referida compensação, deverão ser sopesados, de um lado, o interesse de uma coletividade, sobre a qual não seria razoável que se fizesse recair o ônus de suportar os investimentos adicionais em relação à infraestrutura urbana, e, de outro, o interesse individual do proprietário de construir, cotejado com a sua disponibilidade de pagamento.

Há, portanto, interesses legítimos que recaem sobre o uso da propriedade, distintos daqueles do proprietário, que deverão ser devidamente contemplados, em um contexto democrático. Frise-se, aliás, que tais interesses não se restringem a pretensões de natureza tão somente social, nos termos em que formulada, inicialmente, a ideia da função social da propriedade. Há interesses econômicos (e relevantes) de terceiros - como, p.ex., a infraestrutura relativa a transporte, e não só público -, interesses de natureza ambiental, consistentes em esgotamento sanitário adequado, sistema de coleta de lixo, etc., ou, ainda, pretensões relacionadas à aspectos históricos e culturais (a se considerar o contexto urbano do imóvel), que também são legítimos e exigem ser devidamente contemplados, em cotejo com os direitos e prerrogativas do proprietário.

Nesse cenário complexo, composto por uma quantidade relevante de interesses a serem contemplados e eventualmente conformados, quer nos parecer que a mera referência à função social da propriedade é insuficiente para se promover uma legitimação democrática que estabeleça, no particular, o efetivo conteúdo do direito de propriedade.

No caso, o estabelecimento do conteúdo do direito de propriedade exigirá a definição, a legitimação e a adequada mensuração das pretensões que poderão recair sobre o exercício do domínio. Por meio de procedimentos democráticos, tais interesses serão cotejados (e conformados), de modo a se fixar como os recursos privados poderão ser alocados e, ainda, como serão distribuídos (ou suportados os ônus de seu incremento) os recursos urbanos, que deverão atender, concomitantemente, proprietários e não proprietários.

O modelo democrático de propriedade, assim, exige - muito além de uma análise dogmática fundamentada em conceituação técnico-jurídica a respeito da natureza do instituto - uma avaliação que contemple os critérios de aferição democrática dos procedimentos que resultam na distribuição dos poderes e prerrogativas inerentes à propriedade e ao contexto urbano, social e econômico envolvido. Afinal, a discussão que envolva limitações ao direito de propriedade, consequências que dele poderão ser 
suportadas por não proprietários (vizinhos ou não), bem como a fixação de um valor pecuniário que sopese tais consequências, caracteriza-se como uma discussão sobre alocação de poder. A solução a respeito de conflitos envolvendo distribuição de poder não pode ocorrer se não sob a égide de procedimentos e regras norteados por critérios democráticos.

7.3.3. A ordem urbanística e o poder normativo da municipalidade. ("RE 607940”)

O Recurso Extraordinário n ${ }^{\circ}$ 607.940/DF, da relatoria do ministro Teori Zavascki, tratou da constitucionalidade da Lei Complementar Distrital 710, de 6 de setembro de 2005, que dispõe sobre uma forma diferenciada de ocupação e parcelamento do solo urbano em loteamentos fechados.

O Procurador-Geral de Justiça do Distrito Federal ingressou com ação direta de inconstitucionalidade contra a referida norma, no âmbito do Tribunal de Justiça do Distrito Federal e dos Territórios, o qual considerou que não haveria nenhuma desconformidade entre a lei impugnada e a Lei Orgânica do Distrito Federal.

Contra a referida decisão, o Ministério Público do Distrito Federal interpôs recurso extraordinário ao Supremo Tribunal Federal, alegando violação ao art. $182, \S \S 1^{\circ}$ e $2^{\circ}$ da Constituição Federal. ${ }^{20}$ Segundo o MPDFT, o acórdão recorrido teria violado a Constituição Federal ao chancelar a permanência no ordenamento de um projeto urbanístico isolado e dissociado do plano diretor, que constitui o instrumento básico da política de desenvolvimento e de expansão urbana em municípios com mais de vinte mil habitantes.

O Supremo Tribunal Federal, diante da relevância da matéria discutida, entendeu que o tema deveria ser submetido à sistemática da repercussão geral, Eis a ementa:

20 Art. 182. A política de desenvolvimento urbano, executada pelo Poder Público municipal, conforme diretrizes gerais fixadas em lei, tem por objetivo ordenar o pleno desenvolvimento das funções sociais da cidade e garantir o bem- estar de seus habitantes.

$\S 1^{\circ} \mathrm{O}$ plano diretor, aprovado pela Câmara Municipal, obrigatório para cidades com mais de vinte mil habitantes, é o instrumento básico da política de desenvolvimento e de expansão urbana.

$\S 2^{\circ}$ A propriedade urbana cumpre sua função social quando atende às exigências fundamentais de ordenação da cidade expressas no plano diretor. 
CONSTITUCIONAL. CRIAÇÃO DE PROJETOS

URBANÍSTICOS. OBRIGATORIEDADE DO PLANO

DIRETOR COMO INSTRUMENTO DA POLÍTICA DE

DESENVOLVIMENTO DOS MUNICÍPIOS.

Possui repercussão geral a questão constitucional atinente à obrigatoriedade do plano diretor como instrumento da política de ordenamento urbano. (TEMA 348 - plano diretor como instrumento básico da política de desenvolvimento e de expansão urbana).

O ministro relator Teori Zavascki, em seu voto, consignou que a Constituição Federal atribuiu ao município uma posição de protagonismo para dispor a respeito de matérias urbanísticas, notadamente pela: (i) elaboração do plano diretor, como instrumento básico da política de desenvolvimento e de expansão urbana; (ii) edição de normas para promover o adequado ordenamento territorial; (iii) fixação de diretrizes gerais com o objetivo de ordenar o pleno desenvolvimento das funções sociais da cidade e garantir o bem-estar de seus habitantes.

De acordo com a Constituição, portanto, o plano diretor é o elemento fundamental para o planejamento urbano e para ordenar o pleno de desenvolvimento das funções sociais da cidade. No âmbito do Estatuto das Cidades, o plano diretor é referido da seguinte forma:

Art. 39. A propriedade urbana cumpre sua função social quando atende às exigências fundamentais de ordenação da cidade expressas no plano diretor, assegurando o atendimento das necessidades dos cidadãos quanto à qualidade de vida, à justiça social e ao desenvolvimento das atividades econômicas, respeitadas as diretrizes previstas no art. 20 desta Lei.

Art. 40. O plano diretor, aprovado por lei municipal, é o instrumento básico da política de desenvolvimento e expansão urbana. 
$\S 1$ o O plano diretor é parte integrante do processo de planejamento municipal, devendo o plano plurianual, as diretrizes orçamentárias e o orçamento anual incorporar as diretrizes e as prioridades nele contidas.

$\S 20$ O plano diretor deverá englobar o território do Município como um todo.

§ 3o A lei que instituir o plano diretor deverá ser revista, pelo menos, a cada dez anos.

$\S 4$ o No processo de elaboração do plano diretor e na fiscalização de sua implementação, os Poderes Legislativo e Executivo municipais garantirão:

I - a promoção de audiências públicas e debates com a participação da população e de associações representativas dos vários segmentos da comunidade;

II - a publicidade quanto aos documentos e informações produzidos;

III - $\mathrm{o}$ acesso de qualquer interessado aos documentos e informações produzidos.

Verifica-se, portanto, que o plano diretor, a teor da redação do Estatuto das Cidades, é o elemento fundamental, por meio do qual a municipalidade formula as políticas públicas urbanas. Assim sendo, ele deve contemplar, na delimitação da destinação das áreas, os interesses dos cidadãos no que concerne à qualidade de vida, justiça social e pretensões econômicas, além, evidentemente, de outros direitos relevantes como o próprio direito de propriedade, o direito ao acesso à educação, direito a um meio ambiente equilibrado, etc.

Por outro lado, a legislação impugnada tem por objetivo regulamentar questões relativas ao uso e ocupação do solo no âmbito de determinados condomínios fechados na cidade de Brasília. Diante de uma realidade inafastável, consistente na proliferação de inúmeros condomínios horizontais fechados, o legislador distrital houve por bem normatizar tais empreendimentos, de modo a evitar ocupações irregulares, também bastante comuns na cidade de Brasília. 
Em seu voto, o ministro relator esclareceu, a propósito, que em diversos municípios brasileiros tem surgido "essas figuras jurídicas singulares - denominadas de condomínios horizontais, condomínios urbanísticos ou loteamentos fechados - que mesclam atributos do condomínio edilício previsto na Lei 4.591/64 e do loteamento conceituado pela Lei 6.766/79".

A rigor, assim, sendo incumbência da municipalidade ordenar o uso e ocupação do solo urbano, não lhe é facultado ignorar uma realidade que já se encontra estabelecida e disseminada no âmbito dos contextos urbanos brasileiros, de modo que aos municípios urge contemplar juridicamente essa nova estrutura de disposição e organização de habitações familiares.

Nada obstante, no que concerne especificamente ao caso em discussão, o que se avaliou foi a compatibilidade da norma em questão aos dispositivos constitucionais mencionados (art. 182, $\S \S 1^{\circ}$ e $2^{\circ}$ ). A esse respeito, asseverou o ministro Teori Zavascki:

A rigor, a aprovação de uma lei urbanística especial para tratar sobre aspectos de economia interna dessas espécies impróprias de loteamentos não traduz, por si só, qualquer descompromisso com a ideia de globalidade que há de estar presente no plano diretor. Bastaria, para manter a coesão do planejamento da cidade, que o plano diretor considerasse, em seu interior, os zoneamentos da cidade habilitados a receber parcelamentos diferenciados como aquele previsto na Lei Complementar 710/2005. Em outras palavras, o coeficiente de generalidade que a Constituição exige para o plano diretor não determina que ele apresente uma regulamentação detalhada a respeito de cada uma das formas admissíveis de aproveitamento do solo, mas apenas que ele indique onde poderão ser aplicadas essas diferentes modalidades de urbanização no plano global da cidade.

Assim, o ministro relator entendeu que não haveria uma incompatibilidade entre a Lei Complementar 710/2005 e a Constituição Federal, uma vez que o conteúdo da referida norma não, necessariamente, deveria constar do plano diretor. Ou seja, é possível que o município estipule normas especiais para regulamentar o uso e a ocupação do solo 
em relação a itens específicos, eventualmente não abrangidos, por completo, pelo plano diretor. Em não se demonstrando, dessa forma, uma incompatibilidade entre a norma particular e o plano diretor, não há que se falar em inconstitucionalidade da norma.

Com fundamento nesses argumentos, o ministro Teori Zavascki negou provimento ao recurso extraordinário.

É interessante notar, para os fins propostos no presente trabalho, a manifestação do ministro Dias Toffoli em relação à preocupação quanto à fixação da tese que consubstanciaria a decisão tomada pelo Plenário do Supremo Tribunal Federal. Muito embora tenha concordado com os termos do voto do ministro Teori Zavascki, o ministro Dias Toffoli fez considerações relevantes a respeito de eventuais interesses que deveriam ser observados, sob uma perspectiva de legitimação de direitos que seja mais abrangente que os limites dos condomínios. Nesse sentido, asseverou o referido ministro:

Conforme bem ressaltado pelo Ministério Público, a implantação de loteamentos fechados afeta o planejamento urbanístico global e repercute no direito de locomoção, no direito ao uso à ocupação do solo, no meio ambiente, na arrecadação tributária do município, na segurança pública. Tem ainda profunda implicação para a adequada distribuição espacial das atividades socioeconômicas e dos equipamentos urbanos e comunitários, para a justa distribuição dos benefícios e ônus decorrentes do processo de urbanização e para a prevalência do interesse coletivo sobre o individual e do interesse público sobre o privado. Exatamente pelo fato de cada município ter uma situação única no tangente a esses pontos é que não se pode, com base na realidade de um único ente, conferir à hipótese solução excessivamente ampla e genérica.

E, nessa linha de raciocínio, o ministro Dias Toffoli conclui que "embora lei distinta do plano diretor possa vir a regular o ordenamento urbano, esse deverá sempre guardar obediência não apenas para com aquele diploma normativo, mas também para com as garantias constitucionais dos demais cidadãos, aqueles que residem fora dos muros do loteamento fechado". 
A preocupação do ministro Dias Toffoli foi reverberada pelos demais ministros. A rigor, a conclusão prevalecente considerou a necessidade de se preservar o plano diretor como uma norma que não poderia ser alterada por legislação específica, mas sim por procedimentos específicos de revisão que respeitassem as suas diretrizes de elaboração. Como elemento básico e global de ordenamento urbano, o plano diretor não deveria se submeter ao talante e ao dinamismo de interesses casuísticos que possam vir a movimentar a produção ordinária de normas.

Nesse exato sentido, argumentou o ministro Luis Roberto Barroso:

Presidente, só para deixar claro, eu estou de acordo com a tese também e apenas acho - e concordo com o Ministro Toffoli - que o plano diretor é elaborado em circunstâncias peculiares, com audiências públicas, com debates, com mobilização. De modo que eu estou de acordo que ele só possa ser modificado por um procedimento específico também.

Defendeu-se, assim, tanto nos votos divergentes quanto naqueles que acompanharam o voto do ministro relator, uma primazia das diretrizes do plano diretor, exatamente por se considerar, no dizer do ministro Fachin, "os requisitos materiais ou substanciais do plano diretor", o que o conferiria uma relevante "dimensão material".

E, de fato, ao se examinar o procedimento de elaboração do plano diretor, verificase que há um arcabouço normativo relevante que objetiva, exatamente, permitir uma maior participação da comunidade eventualmente afetada pelas normas a serem editadas. O procedimento de elaboração do referido instrumento, diferentemente do que se sucede com a edição de leis ordinárias, objetiva instituir mecanismos diversificados para contemplar, na medida do possível, a maior quantidade de interesses envolvidos.

Como visto, da redação do artigo 40 do Estatuto das Cidades decorre a obrigação de se realizar audiências públicas, com a participação da população e de associações representativas; publicidade quanto aos documentos e informações; amplo acesso aos interessados em relação aos documentos produzidos.

Assim, além das normas regulares que normatizam o procedimento de produção de normas ordinárias, por meio da democracia representativa, a intenção do Estatuto das Cidades foi de conferir maior legitimidade democrática à elaboração das políticas de ordenamento urbano. 
Nesse sentido, é oportuno retornar aos apontamentos realizados por Robert Dahl (Dahl, 1989), e especificados no item 7.2., para considerar que a normatização inserta no plano diretor objetiva alcançar maior legitimação, promovendo amplo acesso à população no procedimento de sua elaboração; fomentando a divulgação das informações que subsidiam as decisões tomadas; e outorgando maior autonomia aos partícipes dos debates públicos, independentemente de mandato político.

Trata-se, assim, à toda evidência, do reconhecimento de que o direito de propriedade, notadamente em um contexto urbano, poderá envolver diversos interesses legítimos em relação ao seu exercício.

Diante disso - e nesse aspecto reside a relevância do acórdão mencionado para os fins deste trabalho -, devem-se prestigiar mecanismos e procedimentos que promovam a legitimação de pretensões de cidadãos, sejam proprietários ou não proprietários, de modo a se desenvolver o conteúdo do direito de propriedade, sob perspectivas democráticas, em adequação, portanto, aos princípios do Estado Democrático de Direito. 


\section{Conclusão}

O dilema da propriedade está indissociavelmente relacionado exatamente à falta de propriedade para os não proprietários. Refere-se, assim, aos próprios fundamentos da exclusão vis-à-vis os motivos que justificam atribuir algo a alguém. Nesse sentido, é necessário enfatizar que tal problemática não decorre, propriamente, do sistema de propriedade privada, mas, sim, da escassez de bens materiais, limitados diante de desejos e necessidades que não se limitam na mesma proporção. Assim, a escassez de recursos é um problema que é enfrentado por qualquer sistema de decisão a respeito da forma de alocação, desde o momento em que percebemos não nos encontrarmos no estado natural idealmente proposto por John Locke.

Nesse sentido, a análise do direito de propriedade pressupõe o desenvolvimento de uma explicação plausível, por alguma perspectiva de pensamento, a respeito de como se efetivará, em um determinado contexto político, social e econômico, a distribuição de recursos. Essa explicação torna-se ainda mais relevante ao se compreender que a distribuição de propriedade importa, de certo modo, na distribuição de poder no âmbito de uma determinada sociedade.

No contexto das sociedades hodiernas, a discussão sobre alocação de recursos e direito de propriedade é ainda mais complexa. Isso porque, como visto, o direito de propriedade tem um caráter inter-relacional. E na medida em que as relações interpessoais se tornam mais diversificadas e intensas, as discussões sobre direito de propriedade também se tornam mais delicadas.

De fato, tome-se, como exemplo, uma determinada propriedade imobiliária urbana, em uma grande cidade brasileira, na qual se pretende desenvolver um empreendimento. Uma análise a respeito de seu uso e ocupação não se restringe, tão somente, a uma discussão sobre os atributos da propriedade e limitações administrativas. Discutir-se-á os impactos na vizinhança; os impactos no meio-ambiente; os impactos na infraestrutura urbana de transporte, esgotamento sanitário, fornecimento de água e de energia elétrica; disponibilidade/saturação de equipamentos urbanos como escolas, delegacias, postos de saúde; estrutura de tributação das operações imobiliárias e correlatas; coeficientes de aproveitamento para edificações; especificação da destinação da área (se de uso comercial, residencial, misto, etc.), entre outros aspectos. 
Ora, em cada um dos itens a serem analisados se defrontarão diversos interesses, de distintos titulares, e, em grande parte, sustentados por valores legítimos de quem os pleiteia. Em cada um desses aspectos, deverão ser tomadas decisões relevantes que resultarão em menor ou maior disponibilidade de determinado recurso, seja em relação ao proprietário do terreno, aos futuros proprietários das unidades imobiliárias, àqueles que desejam ter acesso à propriedade imobiliária, ou aos que dela não dispõem.

Dilemas típicos dos contextos urbanos brasileiros, como gentrificação, ausência de acesso à moradia, saturação de infraestrutura urbana de transporte público, fornecimento de água, esgotamento sanitário, entre outros inúmeros, dizem respeito exatamente às decisões que são tomadas em relação à alocação de recursos associados à propriedade imobiliária e da adequada análise das respectivas externalities. Sim, pois, o direito de construir cotejará o interesse da vizinhança com os do proprietário relacionados ao empreendimento; as pretensões relativas ao meio-ambiente poderão ser confrontadas com aquelas de futuros adquirentes; a necessidade do Estado de arrecadar receitas poderá limitar o acesso à propriedade imobiliária, em razão do impacto no preço do metro quadrado, e assim por diante.

A análise da legitimação de interesses e a sua ponderação, nesse contexto, longe está de ser tarefa trivial.

Para o alcance de tais objetivos, como se demonstrou anteriormente, não parece ter utilidade alguma a compreensão da propriedade - segundo a conceituação de nossa doutrina clássica - com base em seus atributos, em paráfrases do disposto no artigo 1.228 do Código Civil.

Nesse sentido, um dos propósitos do presente trabalho é demonstrar que, para tal desiderato, não se prescinde da análise e fundamentação das escolhas relativas ao sistema de distribuição de recursos (e, portanto, de poder), sob perspectivas ético-valorativas. Frise-se, portanto, a necessidade de se estabelecer (e da forma mais transparente possível) os fundamentos que norteiam o estabelecimento dos critérios decisórios relativos à questão de alocação de recursos.

Sob essa compreensão da propriedade, foram apresentados os argumentos elaborados no âmbito do liberalismo clássico que muito contribuíram para o desenvolvimento da atual concepção do domínio como um direito, de caráter geral, e com relevantes alicerces em princípios éticos liberais.

Assim, objetivou-se apresentar os fundamentos de Locke em relação à sua concepção de igualdade, caracterizada pela ideia de intelecto democrático, que 
consistiria, como visto, em uma capacidade intelectual suficiente a possibilitar que determinada pessoa apreenda a existência de Deus e, notadamente, de seu desiderato perante Ele.

Nos termos anteriormente explicitados, a ideia de que os seres humanos detêm, em caráter geral, uma capacidade (democrática, na terminologia de Jeremy Waldron) de compreender o seu papel perante Deus, leva à compreensão de que cada um, de forma autônoma, é capaz de alcançar uma perspectiva de bem.

A concepção de igualdade de Locke influenciou a sua perspectiva sobre direito de propriedade, notadamente no que concerne ao direito natural de acesso, desde que atendida a condição da mistura entre o trabalho e a coisa encontrada em seu estado natural. Em outras palavras, muito embora o direito de propriedade, sob a perspectiva de Locke, estivesse vinculado à verificação de um determinado fator (mistura), a própria condição humana, por si só, garantiria, de forma geral, o acesso ao domínio.

Em seguida, mais especificamente no item 3.2, foram elaboradas as contribuições de Kant no estabelecimento de uma perspectiva de propriedade, fundamentada no seu sistema ético. Como visto, o sistema ético kantiano é lastreado, primordialmente, em uma concepção particular de liberdade, relacionada à ideia de legislador universal e o imperativo categórico. Tais elementos constituem, como visto, o cerne da ideia de liberdade como a "independência do arbítrio coercitivo de um outro" (Kant I. , 2014, p. 42).

Nos termos em que se explicitou anteriormente, na concepção kantiana, o direito de propriedade está intrinsecamente vinculado à ideia de que o "meu de direito" é aquilo a que estou ligado de tal maneira que o uso que um outro quisesse dele fazer sem meu consentimento haveria de me lesar. (Kant I. , 2014, p. 51)

A partir de tal perspectiva (de que ora se dá apenas breve notícia) é que Kant fundamenta sua concepção de direito de propriedade na liberdade, como único direito inato e, portanto, como um valor em si mesmo, ou seja, que estabelece suas próprias medidas, independentemente de outras pretensões de caráter finalístico.

Ademais, é sempre oportuno reiterar a relevância do sistema ético kantiano como um contraponto importante às concepções puramente utilitaristas.

De fato, a avaliação de condutas (ou decisões) por critérios puramente finalísticos (de bem-estar ou felicidade, p.ex.), pode resultar no que Posner denominou de monstruosidade moral do utilitarismo (Posner, 1979, p. 117). Nesse contexto, ao se prestigiar decisões orientadas tão somente por finalidades pretendidas, é inevitável que 
valores universalizáveis e relevantes sejam desconsiderados, em benefício da felicidade de uma maioria opressora.

Trata-se de uma armadilha que deve ser evitada ao se apreender a formação do conteúdo do direito de propriedade, sob perspectivas democráticas. De fato, nesse aspecto, é importante reconhecer que a função social da propriedade está efetivamente relacionada a critérios de natureza finalística.

Como se demonstrou no capítulo 4, a função social da propriedade, nos termos em que formulada por Duguit, tem seus alicerces na ideia de dever imposto ao titular do domínio, no sentido de exercer as suas prerrogativas sob a orientação dos interesses finalísticos determinados por um bem comum (Duguit, 1912, pp. 165-166)

A perspectiva de Duguit foi elaborada, também como visto, no âmbito de grave crise do liberalismo. Referido contexto de ocaso do liberalismo clássico - profundamente marcado por conflitos sociais - foi bastante explorado por autores como Marx, Durkheim e Auguste Comte. Referidos autores - ainda que por fundamentos e pretensões marcadamente distintos - propuseram perspectivas de compreensão da realidade que demonstraram a inviabilidade prática de sistemas éticos dissociados do mundo material.

A título de ilustração, ressalta-se a inegável força da afirmação de Karl Marx, ao contra-argumentar a viabilidade da ideia de libertação metafísica hegeliana, quando assevera que "não é possível libertar os homens enquanto não estiverem em condições de obter alimentação e bebida, habitação e vestimenta, em qualidade e quantidade adequadas" (Marx \& Engels, 1993, p. 65).

Portanto, os argumentos dos referidos autores revelaram, de um lado, a necessidade de superação do liberalismo clássico e, de outro, a possibilidade de legitimação de interesses de natureza social, relacionados a aspectos materiais relevantes, outrora ignorados.

Essa evolução, evidentemente, resultou em impactos significativos - com tais características - na forma de percepção da propriedade privada. A esse respeito, foi demonstrado - reitere-se, em benefício da ênfase - que a ideia de função social da propriedade constitui um produto.

Nesse sentido, e no que se refere especificamente ao direito de propriedade, Luiz Edson Fachin, conforme também demonstrado anteriormente, delineia a sua função social como uma projeção de reação anti-individualista, com o fim de se instituir um conceito dinâmico de propriedade. (Fachin, 1988, p. 19) 
E, de fato, com o propósito de, sob perspectivas de natureza finalística, avaliar, sopesar e propor medidas relacionadas ao problema da alocação de recursos, as ferramentas utilitaristas, assim como as elaboradas no âmbito da denominada Law \& Economics são extremamente relevantes.

Procurou-se, dessa forma, demonstrar, no capítulo 5, as novas perspectivas advindas de teorias relacionadas ao utilitarismo e à análise econômica do direito, seja na denominada dimensão positiva, seja na dimensão normativa. Referidas perspectivas são de inegável utilidade no exame e proposição de medidas que objetivem alcançar determinado fim, orientado por aspectos sociais, econômicos ou políticos.

No âmbito do capítulo 6, objetivou-se realizar um breve escorço sobre a constitucionalização do Direito Civil. Além das considerações de caráter geral sobre o tema, buscou-se enfatizar o contexto histórico e político dos poderes constituintes pátrios, no que se refere especificamente ao tratamento do direito de propriedade no texto das constituições federais. Nesse sentido, procurou-se alcançar um norte para a compreensão do processo de constitucionalização do direito de propriedade no Brasil e seu respectivo perfil ideológico.

Em relação ao tema, e a título de mera sintética notícia, é de se destacar os constantes esforços dos poderes constituintes para contemplar perfis ideológicos distintos, ainda que cada um dos textos constitucionais pudesse ser caracterizado por uma orientação em algum determinado sentido, com maior prevalência - como exemplo, menciona-se a Constituição de 1937, conhecida como "a Polaca", por sua influência da Constituição Polonesa.

Referido amálgama, composto por interesses plurais - notadamente na Constituição Federal de 1988 - revela exatamente uma tentativa de conciliação entre pretensões de origem diversa, ainda que legítimas. Não é por acaso, assim, o evidente cotejo, no texto constitucional vigente, entre a garantia ao direito de propriedade e o dever de se respeitar a sua função social.

A convivência de tais princípios, nesse contexto, também foi objeto de tratamento, especificamente no item 6.3, ao se analisar a relevante problemática relacionada à eficácia dos direitos fundamentais, quanto ao direito de propriedade constitucionalizado.

Por fim, no capítulo 7, e diante dos fundamentos desenvolvidos durante o trabalho, objetivou-se demonstrar uma teoria de direito sobre propriedade. Nesse particular, foram apresentados os argumentos relacionados à compreensão da propriedade como um direito, qualificado por interesses e valores de caráter universalizável e suficientemente 
relevantes, por si sós, de modo a justificar a sua garantia em um contexto de legitimidade democrática, de forma independente, em sua essência, de qualquer critério valorativo outro, distinto dos valores intrínsecos relacionados ao domínio.

Procurou-se apresentar, ainda, que a discussão sobre direito de propriedade envolve, a rigor, diversos interesses legítimos relacionados ao domínio, incluindo-se pretensões do proprietário e dos não proprietários. Tal percepção, como visto, fundamenta a compreensão da propriedade sob critérios de legitimação democrática de interesses.

Nesse sentido, pretendeu-se demonstrar que, apenas por procedimentos democráticos, é que se faz possível alcançar uma conformação, devidamente legitimada no âmbito do Estado Democrático de Direito, do conteúdo do direito de propriedade.

No contexto brasileiro hodierno, portanto, deixar de compreender o direito de propriedade sob a perspectiva do modelo democrático - nos termos, p.ex., em que pretende a doutrina civilista clássica -, é permitir que critérios ético-valorativos sejam empregados na conformação de seu conteúdo, de forma sub-reptícia e, portanto, não transparente, como modo de se sobrepor escolhas (ideologicamente norteadas) de um determinado grupo de interesses em detrimento dos demais.

Trata-se, dessa forma, de meio de imposição de interesses não legitimados democraticamente para o fim de estabelecer critérios próprios de decisão para alocação de recursos (e, portanto, de distribuição de poder) não condizentes com os princípios e valores que norteiam a ideia de Estado Democrático de Direito.

Diante do exposto, portanto, sopesada a devida relevância de um sistema de decisão que atribui ao particular a palavra final a respeito da alocação de determinado recurso, bem como considerados os respectivos impactos nas relações sociais, políticas e econômicas, e os interesses que poderão advir dessas interações, há que se reconhecer os critérios democráticos de legitimação, a que acima se aludiu, como instrumentos para se alcançar a conformação (ainda que dinâmica) do conteúdo do direito de propriedade. 


\section{Bibliografia}

Alexander, G. S. The global debate over constitutional property: lessons for American takings jurisprudence. Chicago: University of Chicago Press. (2006)

Alves, J. C. Direito Romano (16 ${ }^{\mathrm{a}}$ ed.). Rio de Janeiro: Forense. (2014)

Alvim, J. M. A função social da propriedade e os diversos tipos de direito de propriedade, e a função social da posse. Em J. A. Alvim, \& E. A. Cambler, Estatuto da Cidade (pp. 21-61). São Paulo: Revista dos Tribunais. (2014).

Araújo, M. A. A mitigação do absolutismo no direito de propriedade imobiliária. São Paulo : Tese de Doutorado. Pontífica Universidade Católica de São Paulo PUC/SP. (2007).

Aristóteles. Política (2 $2^{\text {a }}$ ed.). (M. d. Cury, Trad.) Brasília: Editora Universidade de Brasília. (1988).

Aron, R. As Etapas do Pensamento Sociológico (4 ed.). (S. Bath, Trad.) São Paulo: Martins Fontes. (1993).

Bentham, J. An Introduction to the Principles of Morals and Legislation. Ontário: Batoche Books. (2000). . The Rationale of Reward. Londres: John and H. L. Hunt, 1825. (2008).

Bobbio, N. O Positivismo Jurídico: Lições de Filosofia do Direito. (M. Pugliesei, E. Bini, \& C. E. Rodrigues, Trads.) São Paulo: Ícone. (1995).

Bonavides, P., \& Andrade, P. História Constitucional do Brasil. Rio de Janeiro: Paz e Terra. (1991).

Bottomore, T. Dicionário do Pensamento Marxista. Rio de Janeiro: Jorge Zahar Editor. (1988).

Calabresi, G., \& Bobbitt, P. Tragic Choices. Nova Iorque: W. W. Norton \& Company. (1978).

Calabresi, G., \& Melamed, A. D. Property Rules, Liability Rules, and Inalienability: One View of The Cathedral. Harvard Law Review, 85, 1089-1128. (1972).

Castro, M. F. Análise Jurídica da Política Econômica. Revista da Procuradoria-Geral do Banco Central, 3 n. 1, 17-70. (2009).

Coase, R. H. The Problem of Social Cost. (T. U. Press, Ed.) Journal of Law and Economics, 3, 1-44. (1960). 
Comte, A. Curso de Filosofia Positiva. (V. Civita, Ed., J. A. Giannoti, \& M. Lemos, Trads.) São Paulo: Abril Cultural. (1978). . The Positive Philosophy (Vol. 3). Londres: Batoche Books. (2000).

Dahl, R. A. Decision-making in a democracy: The Supreme Court as a national policymaker. Journal of Public Law, 6, 279-296. (1957).

. Democracy and its critics. New Haven: Yale University Press. (1989).

Demsetz, H. Toward a Theory of Property Rights. The American Economic Review, Papers and Proceedings of the Seventy-ninth Anual Meeting of the American Economic Association, 57, $n^{\circ}$ 2, 347-359. (1967).

Didier Júnior, F. A função social da propriedade e a tutela processual da posse. Revista de Processo, 161, 9-20. (Julho de 2008).

Diniz, M. H. Curso de Direito Civil Brasileiro (19 ed., Vol. v.4: direito das coisas). São Paulo: Saraiva. (2004).

Donagan, A. Is There a Credible Form of Utilitarism? Em A. Donagan, The Philosophical Papers of Alan Donagan (pp. 132-143). Chicago: University of Chicago Press. (1994).

Duguit, L. Les Transformations Générales du Droit Privé Depuis le Code Napoléon. Paris: Librarie Félix Alcan. (1912).

Durkheim, É. Da Divisão do Trabalho Social. Em J. A. Giannotti, Durkheim: (Os Pensadores) (C. A. Moura, L. Cary, M. G. Esteves, \& J. V. Esteves, Trads.). São Paulo: Abril Cultural. (1978).

Coleção Grandes Cientistas Sociais. (J. A. Rodrigues, Ed.) São Paulo: Ática. (2000).

Fachin, L. E. A função social da posse e a propriedade contemporânea: uma perspectiva da usucapião imobiliária rural. Porto Alegre: Sergio Antonio Fabris. (1988).

. Homens e mulheres do chão levantados. Em L. E. Fachin, Questões do Direito Civil brasileiro contemporâneo (pp. 49-65). Rio de Janeiro: Renovar. (2008).

. Conceituação do Direito de Propriedade. Doutrinas Essenciais de Direitos Humanos, 2, 813-852. (Agosto de 2011).

Fehr, E., Fischbacher, U., \& Gächter, S. Strong Reciprocity, Human Cooperation and the Enforcement of Social Norms. Human Nature, 13, 1-25. (2002).

Franco, A. A.. Discurso proferido na sessão de 5 de outubro de 1988. Fonte: Câmara dos Deputados: http://www2.camara.leg.br/atividade- 
legislativa/plenario/discursos/escrevendohistoria/25-anos-da-constituicao-de1988/constituinte-1987-1988/pdf/Affonso\%20Arinos\%20-

\%20DISCURSO\%20REVISADO.pdf (acessado em 13 de 12 de 2016)

Frazão, A. Empresa e Sociedade: Função social e abuso do poder econômico. São Paulo: Quartier Latin do Brasil. (2006).

Giannoti, J. A. Comte: Vida e Obra. Em A. Comte, Auguste Comte: Os Pensadores. São Paulo: Abril Cultural. (1978).

Grau, E. R. Direito Urbano: Regiões Metropolitanas, Solo Criado, Zoneamento e Controle Ambiental, Projeto de Lei de Desenvolvimento Urbano. São Paulo: Revista dos Tribunais. (1983).

Grossi, P. História da propriedade e outros ensaios. (L. E. Fonseca, Trad.) Rio de Janeiro: Renovar. (2006).

Hardin, G. The Tragedy of the Commons (Vol. 162). New York: American Association for the Advancement of Science. (1968).

Hegel, G. W. Princípios da Filofia do Direito. São Paulo: Martins Fontes. (2009). Fenomenologia do Espírito. São Paulo: Ed. Abril, Col. Os Pensadores. (1974)

Hesse, K. Derecho Constitucional y Derecho Privado. Madrid: Editorial Civitas. (1995).

Kant, I. Fundamentação da Metafísica dos Costumes. (P. Quintela, Trad.) Lisboa: Edições 70. (2011).

. Princípios Metafísicos da Doutrina do Direito. (J. Beckenkamp, Trad.) São Paulo: WMF Martins Fontes. (2014).

. Crítica da Razão Prática (4ª ed.). (V. Rohden, Trad.) São Paulo: WMF Martins Fontes. (2016).

Larenz, K. Derecho Civil: Parte General. Madrid: Editora Revista de Derecho Privado. (1978).

Lima, F. H. Propriedade, Estado e Mercado. Tese de livre docência. Universidade de Brasília. Brasília. (2010)

Lôbo, P. L. Constitucionalização do Direito Civil. Revista de Informação Legislativa, 141, 99-109. (jan/mar de 1999 (36)).

Locke, J. Segundo Tratado Sobre o Governo. São Paulo: Martin Claret. (2011).

An Essay Concerning Human Understanding. Adelaide: University of Adelaide. (2015). 
Marx, K. O 18 de Brumário de Luís Bonaparte. (L. Konder, Trad.) São Paulo: Martin Claret. (2007)

Grundrisse. (M. Duayer, \& N. Schneider, Trads.) São Paulo: Boitempo. (2011).

Marx, K., \& Engels, F. A Ideologia Alemã (9a ed.). (J. C. Bruni, \& M. A. Nogueira, Trads.) São Paulo: Editora Hucitec. (1993).

Manifesto do Partido Comunista. (S. T. Cassal, Trad.) Porto Alegre:

L\&PM. (2006).

Mendes, G. F. O direito de propriedade na Constituição de 1988. Em D. L. Campos, G. F. Mendes, \& I. d. Martins, A evolução do direito no século XXI: Estudos em homenagem ao Professor Arnoldo Wald (pp. 77-120). São Paulo: Almedina. (2010).

Direitos Fundamentais e controle de constitucionalidade: estudos de direito constitucional (4a edição ed.). São Paulo: Saraiva. (2012).

Cortes constitucionais são muito políticas, diz Gilmar. Fonte: Jota: http://jota.info/justica/cortes-constitucionais-sao-muito-politicas-diz-gilmar27012017 (acessado em 28 de Janeiro de 2017).

Menezes, O. H. Peril da Propriedade Contemporânea (Destaque da Propriedade Fundiária). Tese de Doutorado apresentada ao Programa de Pós-Graduação em Direito da Faculdade de Direito da Universidade de Brasília (UnB). Brasília, Distrito Federal, Brasil: Universidade de Brasília (UnB). (2009).

Mill, S. Utilitarianism. Londres: Electric Book Company. (2001).

North, D. Institutions, economic growth and freedom: an historical introduction. Em M. Walker, Freedom, democracy and economic welfare (pp. 3-26). Napa Valley : Fraser Institute. (1988).

Nozick, R. Anarquia, Estado e Utopia. (F. Santos, Trad.) São Paulo: WMF Martins Fontes. (2016).

Pereira, C. M. Instituições de Direito Civil (22a ed., Vols. IV - Direito Reais). Rio de Janeiro: Forense. (2014).

Perlingieri, P. Perfis do Direito Civil: Introdução ao Direito Civil Constitucional (3 ${ }^{\mathrm{a}}$ Edição ed.). (M. C. Cicco, Trad.) Rio de Janeiro: Renovar. (2007). O Direito Civil na legalidade constitucional. (M. C. Cicco, Trad.) Rio de Janeiro: Renovar. (2008). 
Pietro, M. S. Função Social da Propriedade Pública. Em L. C. Wagner Junior, Direito Público: Estudos em homenagem ao Professor Adilson Abreu Dallari (pp. 561572). Belo Horizonte: Del Rey. (2004).

Pinto, V. C. Direito urbanístico: plano diretor e direito de propriedade (4a ed. ed.). São Paulo: Revista dos Tribunais. (2014).

Posner, R. A. The Economic Approach to Law. Texas Law Review, 53, 757. (1975). Utilitarianism, Economics and Legal Theory. Journal of Legal Studies, 8, 103/140. (1979).

Rabahie, M. M. Função Social da Propriedade. Em A. A. Dallari, \& L. V. Figueiredo, Temas de Direito Urbanístico 2 (pp. 213-258). São Paulo: Revista dos Tribunais. (1991).

Rawls, J. Justice as Fairness: a Restatement. Cambridge: Harvard University Press. (2001).

Lectures on the History of Moral Philosophy. Cambridge: Harvard University Press. (2003)

Renner, K. The Institutions of Private Law and Their Social Functions. (A. Schwarzschild, Trad.) Oxon: Routledge. (2001).

Rocha, C. A. O Princípio Constitucional da Função Social da Propriedade. Em R. F. Bacellar FIlho, P. F. Motta, \& R. A. Castro, Direito Administrativo Contemporâneo (pp. 55-103). Belo Horizonte: Editora Fórum. (2004).

Rodrigues Júnior, O. L. A influência do BGB e da doutrina alemã no Direito Civil brasileiro do século XX. 938, p. 79-155. São Paulo: Revista dos Tribunais. (2013).

S. Alexander, G., \& M. Peñalver, E. An Introduction to Property Theory. New York: Cambridge University Press. (2012).

Salama, B. M. O que é Direito e Economia? Getúlio Vargas Foundation Law School, 118. (2008).

Sarlet, I. W. Direitos fundamentais e Direito privado: algumas considerações emtorno da vinculação dos particulares aos direitos fundamentais. Em I. W. Sarlet, $A$ Constituição concretizada: construindo pontes com o público e o privado (pp. 107-163). Porto Alegre: Livraria do Advogado. (2000).

Silva, J. A. Direito Urbanístico Brasileiro (7 $7^{\mathrm{a}}$ edição ed.). São Paulo: Malheiros Editores. (2012).

Singer, J. W. Entitlement: The paradoxes of property. New Haven: Yale University Press. (2000). 
. How Property Norms Construct the Externalities of Ownership. Harvard Law School Public Law Research, Paper No. 08-06, 1-19. (2007). . Democratic Estates: property law in a free and democratic society. Cornell Law Review, 94, 1009-1062. (2009).

. Property law as the law of democracy. Duke Law Journal, 63, 12871355. (2014).

Sundfeld, C. A. Função Social da Propriedade. Em A. A. Dalllari, \& L. V. Figueiredo, Temas de Direito Urbanístico - 1. Função social da propriedade. Controle e preservação ambiental. responsabilidade civil por dano ecológico; ação tutelar do MP. Tombamento. Zoenamento (pp. 1-22). São Paulo: Revista dos Tribunais. (1987).

Tartuce, F.. Direito Civil (8 ed. ed., Vol. v.4: Direito das Coisas). Rio de Janeiro: Forense. (2016)

. Manual de Direito Civil: volume único. (6 $6^{\mathrm{a}}$ Edição ed.). Rio de Janeiro: Forense. (2016)

Tepedino, G. Normas constitucionais e relações de Direito Civil na experiência brasileira. Em G. Tepedino, Temas de Direito Civil: Tomo II (pp. 21-46). Rio de Janeiro: Renovar. (2006).

. O novo e o velho Direito Civil. Em G. Tepedino, Temas de Direito Civil: Tomo II (pp. 398-401). Rio de Janeiro: Renovar. (2006).

. A função Social da Prorpiredade e o Meio Ambiente. Em G. Tepedino, Temas de Direito Civil - Tomo III (pp. 175-200). Rio de Janeiro: Renovar. (2009).

Tepedino, G., \& Schreiber, A. O papel do poder judiciário na efetivação da função social da propriedade. Em J. J. Strozake, Questões Agrárias: julgados comentados e pareceres (pp. 91-131). São Paulo: Método. (2002).

Waldron, J. God, Locke and Equality. New York: Cambridge University Press. (2002). . The Right to Private Property. New York: Oxford University Press. (2002). . Nozick and Locke: filling the space of rights. Social Philosophy \& Policy Foundation, 81-110. (2005).

Weinrib, E. J. Poverty and Private Property in Kant's System of Rights. Notre Dame Law Review, 78, 795-828. Acesso em 10 de 09 de 2016, disponível em http://scholarship.law.nd.edu/cgi/viewcontent.cgi?article=1496\&context=ndlr (2003). 
Williamson, O. Transaction Cost Economics: An Introduction. Economic Discussion Paper, v.3, n.1. Acesso em 7 de agosto de 2015, disponível em http://www.economics-ejournal.org/economics/discussionpapers/2007-3 (2007). 